\title{
3. SITE 415, AGADIR CANYON, DEEP SEA DRILLING PROJECT LEG 50
}

\author{
The Shipboard Scientific Party ${ }^{1}$
}

\section{HOLE 415}

Date occupied: 13 September 1976, 1600 hours

Date departed: 16 September 1976, 1800 hours

Time on hole: 3 days, 2 hours

Position (latitude; longitude): $31^{\circ} 01.72^{\prime} \mathrm{N} ; 11^{\circ} 39.11^{\prime} \mathrm{W}$

Water depth (sea level; corrected $\mathbf{m}$, echo sounding): 2794

Water depth (rig floor; corrected m, echo sounding): 2804

Bottom felt ( $\mathrm{m}$, drill pipe): 2817

Penetration (m): 283

Number of cores: 5

Total length of cored section (m): 45

Total core recovered $(\mathrm{m}): 31.3$

Core recovery $(\%): 70$

Oldest sediment cored:

Depth sub-bottom (m): 283

Nature: Nannofossil marl and chalk

Age: Early Miocene

Measured velocity $(\mathrm{km} / \mathrm{s}): 1.71-2.05$

Basement: Not reached

Principal results: This hole was the pilot hole, designed to provide information for the placement of casing and re-entry assembly. Only five cores were taken, at about 70 -meter intervals. The recovered sediments consist mainly of nannofossil marls, oozes, and chalks, with various admixtures of foraminifer and siliceous debris. Sediments range in age from Quaternary to Early Miocene. Sonic and density logs show excellent correlation with the measurements performed on core samples.

1 Yves Lancelot (Co-Chief Scientist), Départment de Géologie Dynamique, Université Pierre et Marie Curie, Paris, France; Edward L. Winterer (Co-Chief Scientist), Geological Research Division, Scripps Institution of Oceanography, La Jolla, California; Alfonso Bosellini, Geological Institute, University of Ferrara, Ferrara, Italy; Georges A. Boutefeu, Pétrofina Exploration, Brussels, Belgium (Present address: Petrangol, CP 1320, Luanda, Republic of Angola); R. E. Boyce, Deep Sea Drilling Project, Scripps Institution of Oceanography, La Jolla, California; Pavel Cepek, Bundesanstalt für Geowissenschaften und Rohstoffe, Hannover, Federal Republic of Germany; Duane Fritz, Gulf Energies and Minerals International, Houston, Texas; Eric M. Galimov, V. I. Vernadsky Institute of Geochemistry and Analytical Chemistry, U.S.S.R. Academy of Sciences, Moscow; Marthe Melguen, Centre Océanologique de Bretagne, Brest, France; Ilfryn Price, The British Petroleum Company, Ltd., London, England; Wolfgang Schlager, Rosenstiel School of Marine and Atmospheric Science, Miami, Florida; William Sliter, U. S. Geological Survey, Paleontology and Stratigraphy Branch, Menlo Park, California; Kazuo Taguchi, Institute of Mineralogy, Petrology, and Economic Geology, Tohoku University, Sendai, Japan; Edith Vincent, Geological Research Division, Scripps Institution of Oceanography, La Jolla, California; and Jean Westberg, Geological Research Division, Scripps Institution of Oceanography, La Jolla, California.
HOLE 415A

Date occupied: 16 September 1976, 1800 hours

Date departed: 29 September 1976, 2305 hours

Time on hole: 13 days, 5 hours, 5 minutes

Position (latitude; longitude): $31^{\circ} 01.72^{\prime} \mathrm{N} ; 11^{\circ} 39.11^{\prime} \mathrm{W}$

Water depth (sea level; corrected $\mathbf{m}$, echo sounding): 2794

Water depth (rig floor; corrected m, echo sounding): 2804

Bottom felt (m, drill pipe): 2817

Penetration (m): 1079.5

Number of cores: 15

Total length of cored section (m): 122.5

Total core recovered $(\mathrm{m}): 24.55$

Core recovery $(\%): 20$

Oldest sediment cored:

Depth sub-bottom (m): 1079.5

Nature: Marlstone

Age: Albian

Basement: Not reached

Principal results: Hole $415 \mathrm{~A}$ was spot cored down to a total depth of 1079.5 meters, where it was terminated because of technical difficulties. The entire section was only sparsely sampled at this site. Coring started below the level reached in Hole 415 (pilot hole), and the youngest recovered sediments were lower-Eocene mudstones, probably separated by a hiatus from the overlying lower-Miocene marls. Below, the section consists of Paleocene to Albian mudstones and marlstones, with occasional limestones, which are particularly conspicuous in the Paleocene. A major hiatus probably separates the Paleocene and the Cenomanian. The Cenomanian mudstones are characterized by largescale disruption and tectonic superposition. Although the hole could be logged only through the drill pipe (density log only), correlation with lithology appears reliable.

\section{HOLE 415B}

Date occupied: 21 September 1976, 1308 hours

Date departed: 21 September 1976, 1900 hours

Time on hole: 4 hours, 52 minutes

Position (latitude; longitude): $31^{\circ} 01.72^{\prime} \mathrm{N} ; 11^{\circ} 39.11 \mathrm{~W}$

Water depth (sea level; corrected m, echo sounding): 2794

Water depth (rig floor; corrected m, echo sounding): 2804

Bottom felt (m, drill pipe): 2817

Penetration (m): 64

Number of cores: 2

Total length of cored section (m): 18

Total core recovered $(\mathrm{m}): 3.1$ 


\section{Core recovery $(\%): 17.2$}

Oldest sediment cored:

Depth sub-bottom (m): 64

Nature: Foraminifer-bearing nannofossil ooze

Age: Early Pliocene

Basement: Not reached

Principal results: This hole was drilled accidentally during a missed re-entry attempt. The only recovery was in Core 2 , which yielded 3.1 meters of foraminifer-bearing nannofossil ooze of the early Pliocene. It is believed that during the missed re-entry the bottom-hole assembly hit the rim of the cone and bounced back and into the sea floor. This accidental penetration might have been rather oblique, therefore the sub-bottom depth indicated for the cores might be in error.

\section{BACKGROUND AND OBJECTIVES}

The general objective at this site was to sample sediments contemporaneous with the early phases of the evolution of the central North Atlantic. For that purpose, the site was selected as close to the base of the Moroccan continental slope as possible, where the length of the drill string of Glomar Challenger would be sufficient to reach lowermost sediment layers, and even the basement if both technology and time would permit.

Site 415 is on the north flank of the Agadir Canyon, at $31^{\circ} 01.72^{\prime} \mathrm{N}$ and $11^{\circ} 39.11^{\prime} \mathrm{W}$, about $160 \mathrm{~km}$ off the coast of Morocco and about $30 \mathrm{~km}$ seaward of the edge of a large field of diapirs that borders the Moroccan margin (Figure 1). Seismic data gathered before and after the cruise (Figures 2 and 3 ) show that in the general area a broad swell in the acoustic basement brings it to a depth roughly estimated at 6500 meters below the sea surface; thus, taking advantage of both the rising basement topography and the increasing water depth associated with the Agadir Canyon, there was a possibility to sample most of the sediment layer, with the exception of the uppermost section, and theoretically, to reach basement.

Several high-quality seismic-reflection profiles were made available before and after the drilling cruise. Of these, only the profiles that were communicated for planning purposes by Geophysical Service International (GSI) have not been released for publication. The published profiles that provide the base for our regional interpretation are essentially a multichannel line communicated by K. Hinz of the Bundesanstalt fur Geowissenschaften und Rohstoffe (Meteor 3902 profile) (Figure b-2); a Phillips Company, Ltd. multichannel profile (Figure b-3); and Glomar Challenger single-channel profiles from Legs 47 and 50.

The main reflectors, which have been given color designations corresponding to pencil markings on working documents, are the following (from top to bottom):

1. Brown reflector. The first strong, continuous reflector within the upper, more or less acoustically transparent sequence. It generally lies about 0.5 to $0.7 \mathrm{sec}$ onds below the sea floor, but near the Agadir Canyon the section above the brown reflector is much thinned, owing either to erosion or slower rates of accumulation, or both.

2. Red reflector. A sequence of two or three closely spaced reflectors lying about 0.5 to 0.6 seconds below the brown reflector. Between red and brown, the acoustic layering is more parallel than in the post-brown interval and tends toward less relief than the red reflector. The red reflector regionally lies close to an unconformity; the beds below have more structural relief than those above, and pre-red reflectors often appear truncated at the red line.

3. Orange reflector. Near Site 415 (Phillips line), the orange reflector lies about 0.4 seconds below the red at the west end of the profile, some $10 \mathrm{~km}$ west of Agadir Canyon, but diverges to about 0.7 seconds beneath the canyon. Regionally, this reflector converges on the red toward the north and west. Between orange and red, the reflectors are discontinuous, commonly slightly inclined and generally confused by diffractors. Where the interval is thin, layering is better, whereas the thickest sections (e.g., beneath Agadir Canyon) are the most confused in their seismic structure. The orange reflector is the top of a whole series of remarkably parallel reflectors.

4. Green reflector. Generally parallels the orange reflector, about 0.2 seconds below.

5. Blue reflector. A very strong reflector about 0.6 seconds below the green, and within a sequence of very parallel reflectors.

6. Yellow reflector. The deepest of the reflectors, below and more or less parallel to blue. The yellow reflector is an unconformity, below which lenses and perhaps tilted fault blocks of sediments lie between basement highs. Site 415 , was purposely located over one of these blocks of pre-yellow sediments, west of a basement high just under the Agadir Canyon. At Site 415, the yellow reflector is about 2.6 seconds below the sea floor.

7. Basement. Recognized by a lack of coherent layering. At Site 415, basement is about 3.0 seconds below the sea floor.

Although in theory there was a chance to reach the lowermost parts of the section, a disadvantage of this site was that the blue reflector, assumed to correspond to the top of the particularly interesting objective (upper-Jurassic sediments), apparently lies at depths of about 2500 to 2800 meters below the sea floor. Required penetration was therefore far in excess of that previously attained by the Glomar Challenger. Nevertheless, this technological challenge was also part of the plan for Leg 50 , inasmuch as it was the first time that an entire twomonth leg was devoted to drilling a single hole into thick sediment layers.

The drilling plan called for spot coring of the uppermost 1100 meters of the section, believed to correspond rather closely to the section sampled at Site 370 (Lancelot, Seibold et al., 1978). Below that level, coring was to be continuous until either time constraints or technical difficulties forced us to abandon the site. 

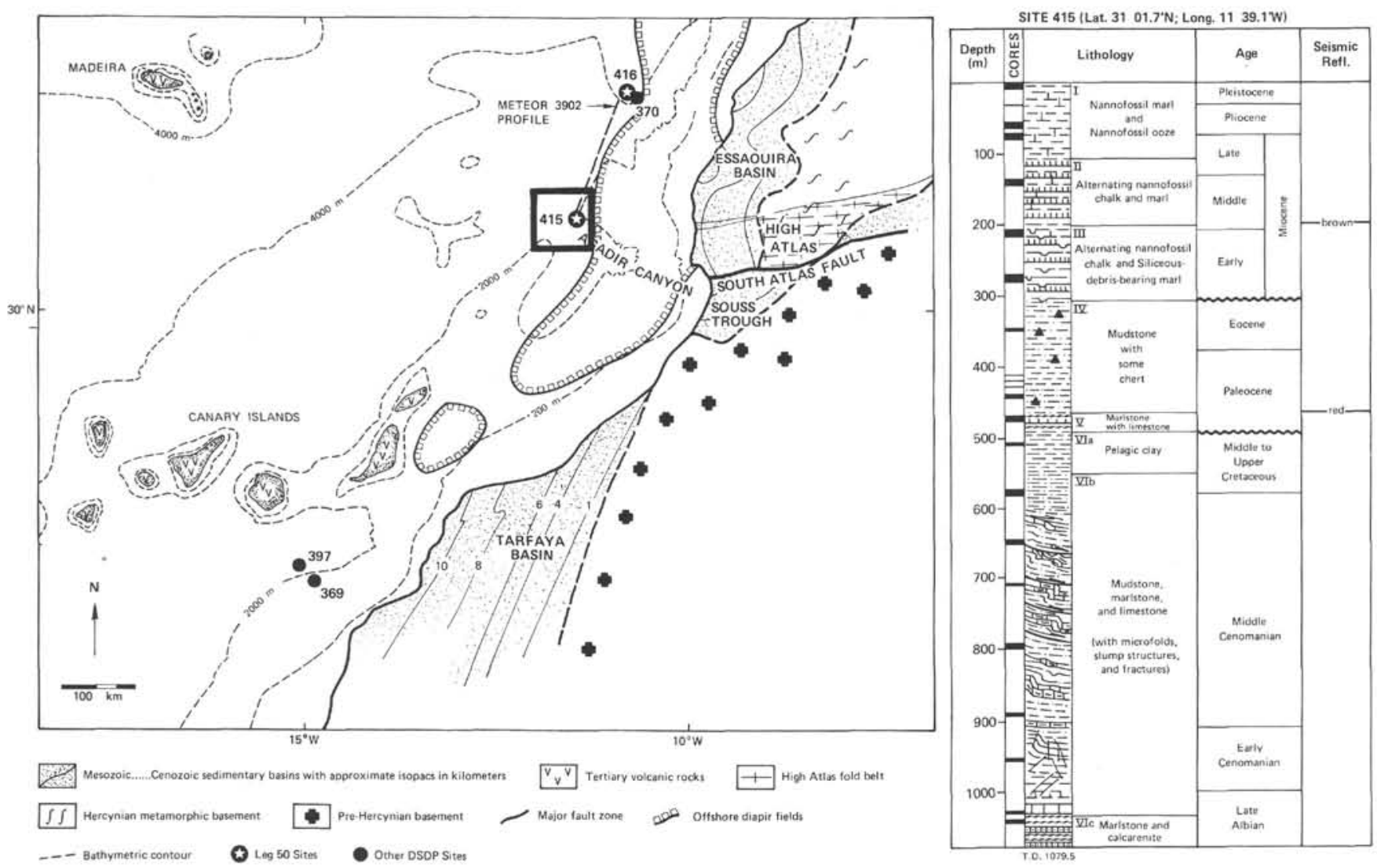

Figure 1. Location of Site 415 and graphic site summary.

\section{OPERATIONS}

\section{From Funchal to Site $\mathbf{4 1 5}$}

The ship left Funchal, on the island of Madeira, at 2335 hours on 11 September 1976, and set a course southeastward toward Site 415 , about 300 miles distant. Continuous seismic-reflection profiles and magnetometer records were obtained along the track, and a wideangle reflection survey, using an expendable sonobuoy, was made while crossing the Seine Abyssal Plain, to check our seismic system. The ship was kept headed toward a point about 40 miles WSW of the target site, located along the track of a multichannel (the unpublished GSI) seismic-reflection profile (see tracks on Figure 4). A course change to $077^{\circ}$ was then made to put us as near as possible on the GSI line, and the ship was slowed to 6 knots. Using both the 80 - and 20 -cubic-inch air guns as sound sources, the wide-angle sonobuoy reflection survey was initiated. After receiving signals from the sonobuoy for a distance of about 10 miles, the signal strength faded badly, and the experiment was terminated.

The details of the approach to the site are shown in Figure 5. We first crossed the Agadir Canyon on an eastward course, both to identify features along the GSI profile and to obtain our own seismic-reflection records, and then turned back on a parallel reciprocal course about 1 mile north, recrossing the canyon and going back up the west slope of the canyon for about 5 miles. On both the east and west crossings of this slope, suitable sites were identified at a depth of about $3.7 \mathrm{sec}-$ onds $(2775 \mathrm{~m})$. The seismic profiles we generated (Figures 6 and 7) look very similar to the upper portion of the GSI profile, and the slope was seen to comprise alternating gentle $\left(\sim 1^{\circ}\right)$ and steeper $\left(\sim 4^{\circ}\right)$ sections. The ship was turned back again to the east for a third crossing of the slope, and a specific target was chosen on a gentle slope at a depth of about 2780 meters. Two miles farther along, the ship made a Williamson turn and we steamed back westward along our previous track to the chosen site; we dropped the acoustic beacon while under way, at 1346 hours on 13 September.

After returning to the beacon, the automatic positioning system was set for an offset from the beacon of 300 feet north and 200 feet west. The corrected echosounding depth at this site was determined to be 2794 meters below sea level, or 2804 meters below the derrick floor.

The position of this offset first hole, Hole 415, as determined by averaging 14 satellite positions taken during two days while the ship was actually drilling there, was $31^{\circ} 01.72^{\prime} \mathrm{N}, 11^{\circ} 39.11^{\prime} \mathrm{W}$.

\section{Hole 415}

Hole 415 was a pilot hole, to explore conditions in the upper few hundred meters of the sediment column as a guide to determine where to land the 16 -inch and $11-3 / 4-$ inch casing. For this pilot hole, the bottom-hole assem- 


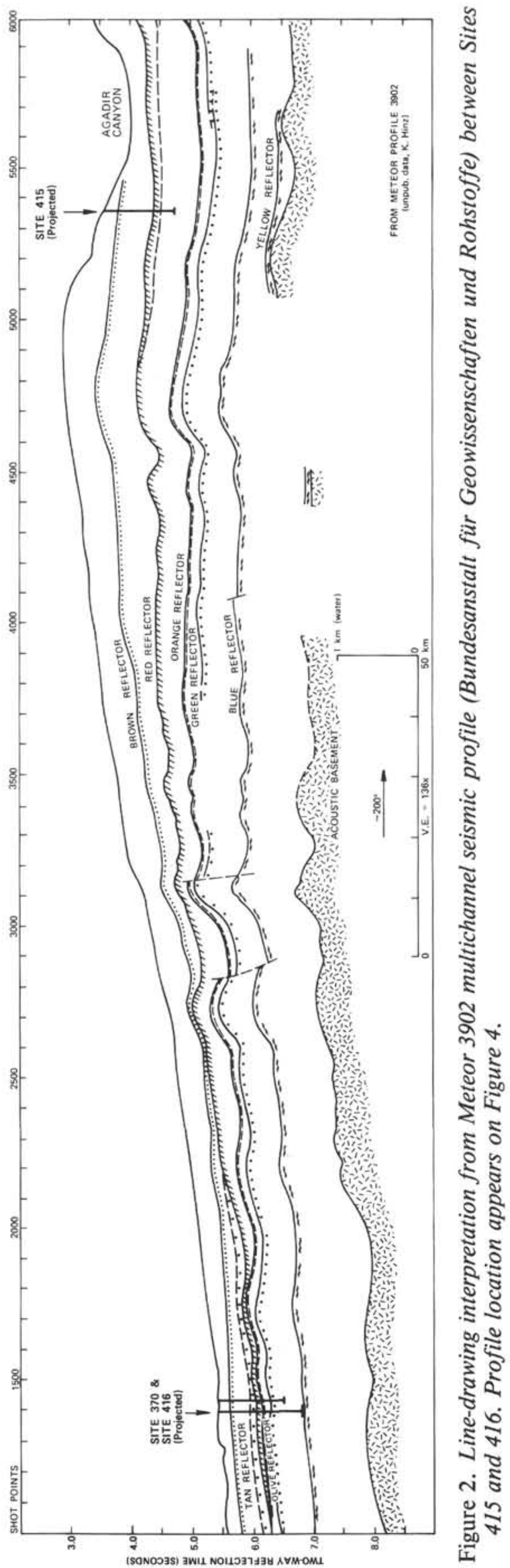

bly and drill string were made up with an acoustic pinger just inside the lower end of the string. The depth to the sea floor, determined from the measured length of drill pipe and the bottom-hole pinger, was 2817 meters. After retrieving the pinger, a core barrel was pumped down, and Core 50-415-1 was punched in the interval 2817 to 2824.5 meters $(0-7.5 \mathrm{~m}$ below sea floor $)$. The core contained a full 9.5 meters of sediment. Because of the probability of squeezing of the soft muds into the core barrel, and because of the slight deflection of the weight indicator at the beginning of coring, it was agreed that 2817 meters would be accepted as the official depth to the sea floor, measured from the derrick floor.

After Core 1 was taken, the bit was raised clear of the mudline and then washed down from 2817 to 2881 meters without rotation, gradually increasing pump pressure as the sediments became stiffer. At 2881 meters (64 meters sub-bottom), rotation was necessary, and the hole was deepened to 2891 meters, where Core 2 was taken in the interval 2891 to 2900.5 meters (74-83.5 m sub-bottom). After retrieving Core 2, the in situ porewater sampling device was dropped into the drill string and allowed to free-fall to the bottom. Upon retrieval, the sampler contained no water sample, because of an error in setting the timer and because of low battery power. Next, the in situ temperature probe was lowered, and a successful bottom-hole temperature measurement was made. A calibration problem resulted in an approximate value of temperature.

The interval 2900.5 to 2954.5 meters (83.5-137.5 m sub-bottom) was drilled, and Core 3 was cut from 2954.5 to 2964 meters (137.5-147 m sub-bottom). After retrieving this core, the pore-water sampler was again lowered, and a water sample was recovered, although the device lost its probe tip. We did not have the proper spare parts, and no further use was made of the device at this site.

After drilling the interval between 2964 and 3024 meters (147-207 m sub-bottom), Core 4 was cut from 3024 to 3033.5 meters (207-216.5 m sub-bottom); we then drilled to 3090.5 meters (273.5 m sub-bottom), where Core 5 was cut from 3090.5 to 3100 meters (273.5-283 m sub-bottom), the total depth reached in this hole. After retrieval of the last core, the in situ temperature instrument was lowered, but the drill pipe could be lowered only to 3094 meters ( $277 \mathrm{~m}$ sub-bottom) because the lower 6 meters of the hole was blocked, possibly by caving. The temperature device was back on deck at 1600 hours on 15 September. To prepare for logging, the bit was released, and the hole was filled with fresh-water mud.

The logging runs were successful, except for the try with the caliper log. This tool would not go past a point about 168 meters below the derrick floor, and it was decided to set it aside for later trimming to permit it to pass easily through the drill string. Runs were then made with three different combinations of Schlumberger tools:

1. Borehole Compensated Sonic (BHC) plus Gamma Ray (GR) Log. 


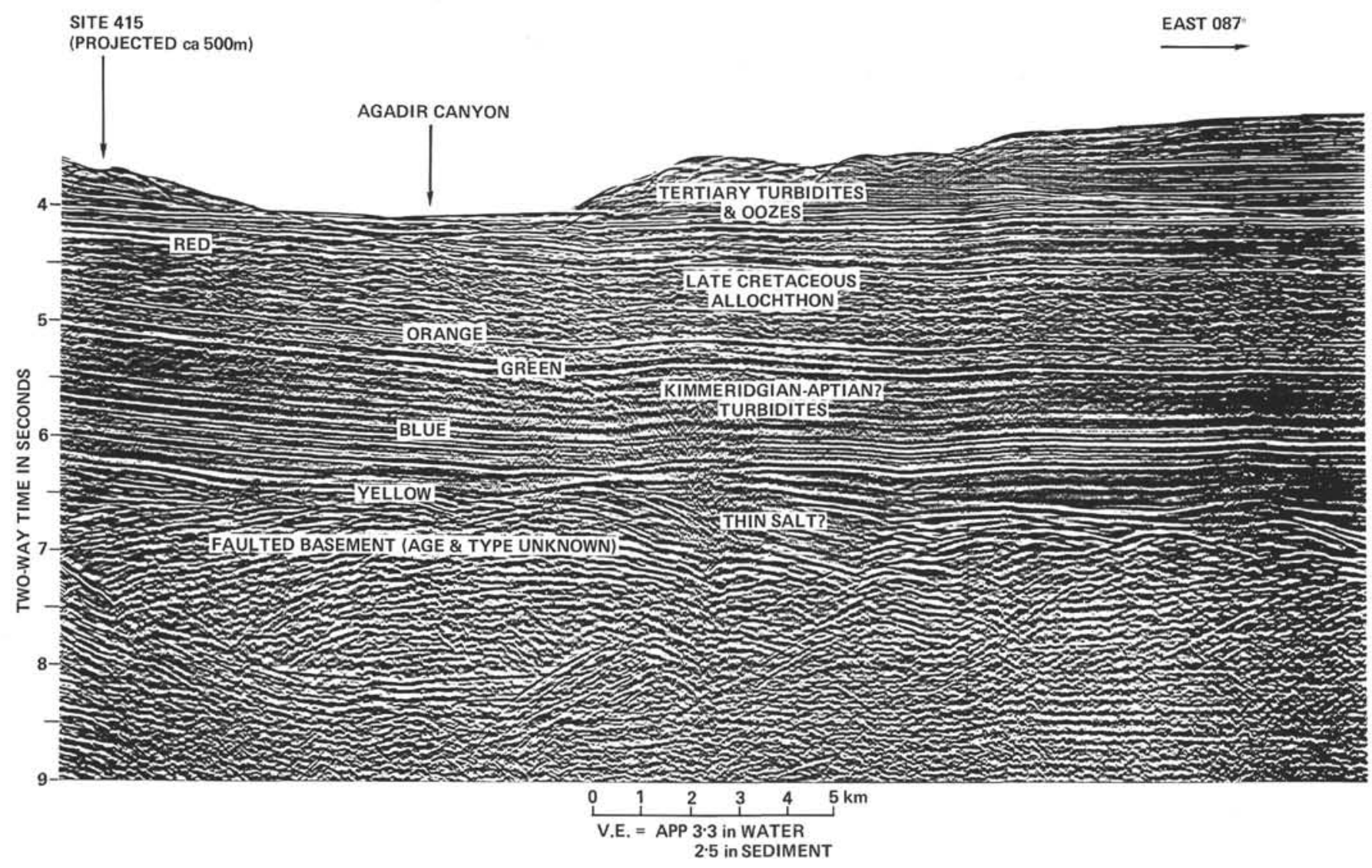

Figure 3. Seismic-reflection profile across Site 415 (projected - 500 meters). The record is SSL line 20, from shot points 2400 to 2629, reproduced with the permission of Phillips Petroleum Co., Ltd. and its partners (BRPM; Agip; Getty Oil, Ltd.; British Petroleum Co., Ltd.). We are grateful to each of these companies for permitting use of this profile in our report.

\section{Compensated Neutron (CNL) plus Formation} Density (FDC) plus GR Log.

3. Dual Induction (DIL) plus Laterolog (LL8) plus GR Log.

The lowest part of the hole was blocked by caving, and the logging tools could not be lowered past about 3084 meters (267 m sub-bottom). During the logging runs, the bottom-hole assembly was suspended to a depth of 2924 meters, so that the upper 107 meters of the hole was behind the pipe and could not be logged. The depth to the end of the bottom-hole assembly from drill-pipe measurement was 2926 meters, a discrepancy of only 2 meters from the Schlumberger measurement.

By 1100 hours on 16 September, the logging tools were back on deck, and the pipe was pulled out of the hole. At 1600, the last of the bottom-hole assembly was on deck, and preparations could begin for Hole 415A.

\section{Hole 415A}

To prepare for drilling Hole 415A, the ship was positioned 100 feet south and 40 feet west of the acoustic beacon on the sea floor. By 1800 hours on 16 September, the re-entry cone had been maneuvered beneath the moon pool, and at 0650 hours the next day the drilling crew began lowering the re-entry cone, the bottom-hole assembly, and the 16-inch casing to the sea floor. To confirm the depth of the sea floor, an attempt was made to core the interval 2797 to 2807 meters, but the core barrel was retrieved empty. A center bit was latched into place and, rather than taking another core to try to establish the depth to the sea floor, the pipe was lowered again. The bit was lowered gradually until the weight indicator flickered at $\mathbf{2 8 1 7}$ meters, suggesting the sea floor at that depth.

The 16 -inch casing was washed in with a $14-7 / 8$-inch bit to a depth of 2880 meters below the derrick floor, or approximately 63 meters below the sea floor. Since the length of casing up to the base of the cone was 68 meters, the top of the cone then should have been at 2812 meters, or about 5 meters above the sea floor. During the washing-in process, downward progress gradually slowed to a rate of a little less than a meter per hour during the last few meters.

After releasing the bottom-hole assembly from the cone and its attached 16-inch casing, drilling was immediately resumed and continued to a depth of 3161.5 meters, or 344.5 meters below the sea floor, where the increasing firmness of the rocks, as judged from the decreasing rate of penetration, suggested that we could safely land the $11-3 / 4-i n c h$ casing. Operations were delayed for three hours because one of the bow thrusters was apparently fouled and could not be operated at full 


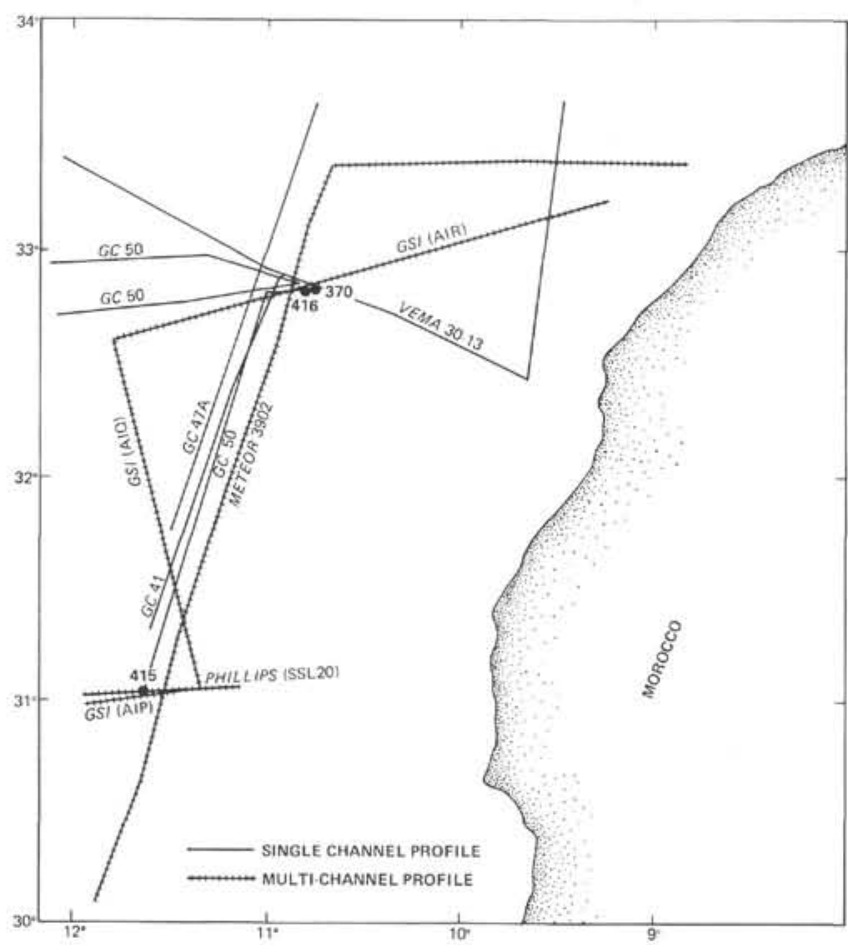

Figure 4. Locations of various seismic profiles in the vicinity of Sites 415 and 416.

power. When the thruster was again restored, the casing, bottom-hole assembly, and drill pipe were lowered to 2806 meters for re-entry.

This first re-entry went very smoothly. The three reflectors on the cone were easily seen, as well as the acoustic beacon, which appeared to be about 40 feet distant from the cone. Reflections from the sea floor suggested that the terrain near the cone was sloping and slightly irregular. About two hours after the re-entry maneuver began, a successful stab was made into the cone, the drill string was run into the hole, and the $11-3 / 4$-inch casing was latched to the cone.

At the moment of latching, the drill-pipe depth to the top of the casing was 2824 meters. The dimensions of the cone and casing hanger assembly are such that the top of the cone should then have been at 2818 meters, and the mud skirt, presumably at the sea floor itself, at 2820.5 meters. Because we had previous indications that the sea floor was at $\mathbf{2 8 1 7}$ meters, it is possible that the cone was in a crater-like depression, or that the cone and 16 -inch casing had sunk some 6 or 7 meters down from their original positions. On the other hand, the reflections seen by the bottom-hole sonic transducer suggested that the top of the cone was at least a little above its general surroundings. We arbitrarily fixed the "official" sea-floor depth for this hole at 2817 meters below the derrick floor, recognizing that this may be in error by a few meters.

The 11-3/4-inch casing was landed at a depth of 3155 meters (338 m sub-bottom) and cemented in place with 100 barrels of cement. A metal cementing plug, rather than a flapper valve, was used to stop off the bottom of the casing during cementing. The cementing was completed by 1220 hours on 20 September, and the pipe was then pulled out of the hole and on deck.

At midnight on 20 September the crew began lowering the drill string toward the sea floor again, this time with a 10-inch bit having four roller cones fitted with teeth about $0.8 \mathrm{~cm}$ long, which we believed might be efficient in penetrating the clay-rich rocks of the Lower Cretaceous. Also in the bottom hole assembly were two 9- $1 / 8$-inch stabilizers, designed to help maintain a straight vertical hole. Another novel element in the system was a packoff assembly designed to insert itself in the cone to divert cuttings into the three 8-inch discharge pipes attached along the underside of the cone. These pipes are designed to carry cuttings at high speed up and away

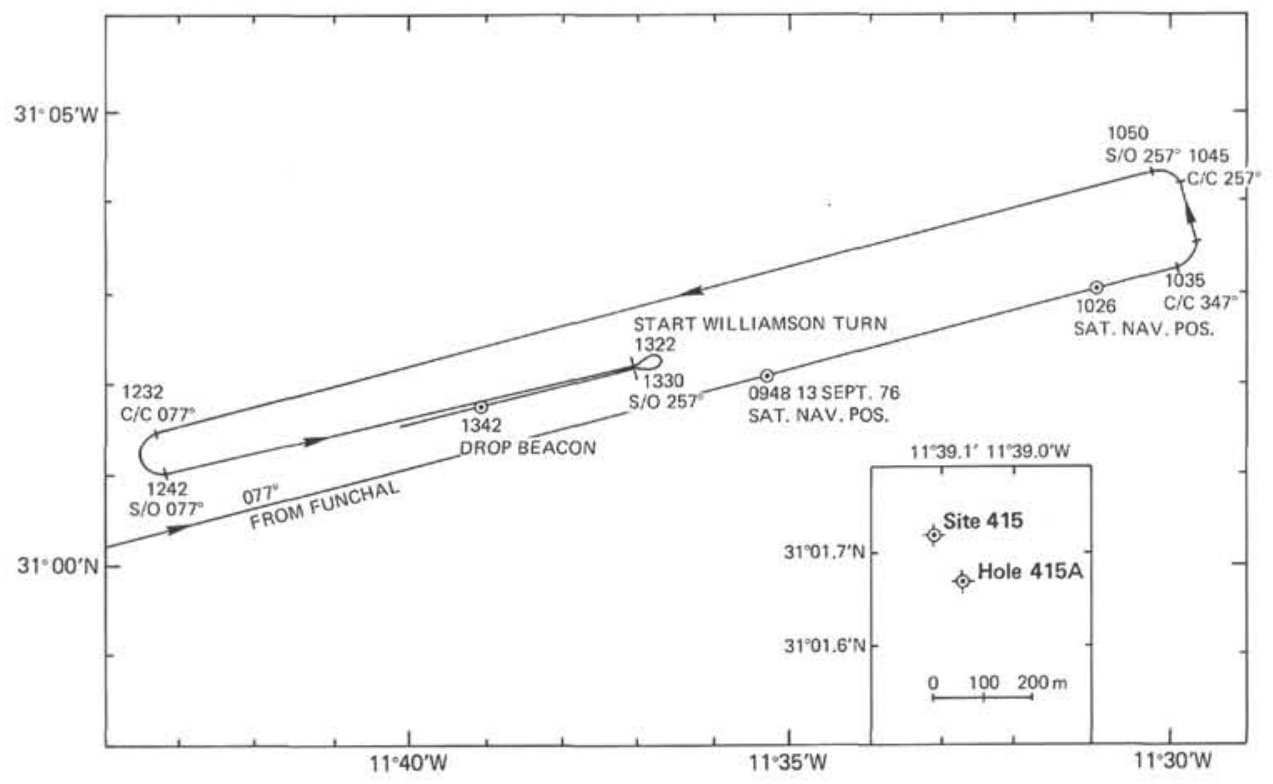

Figure 5. Tracks of Glomar Challenger approaching and leaving Site 415. 

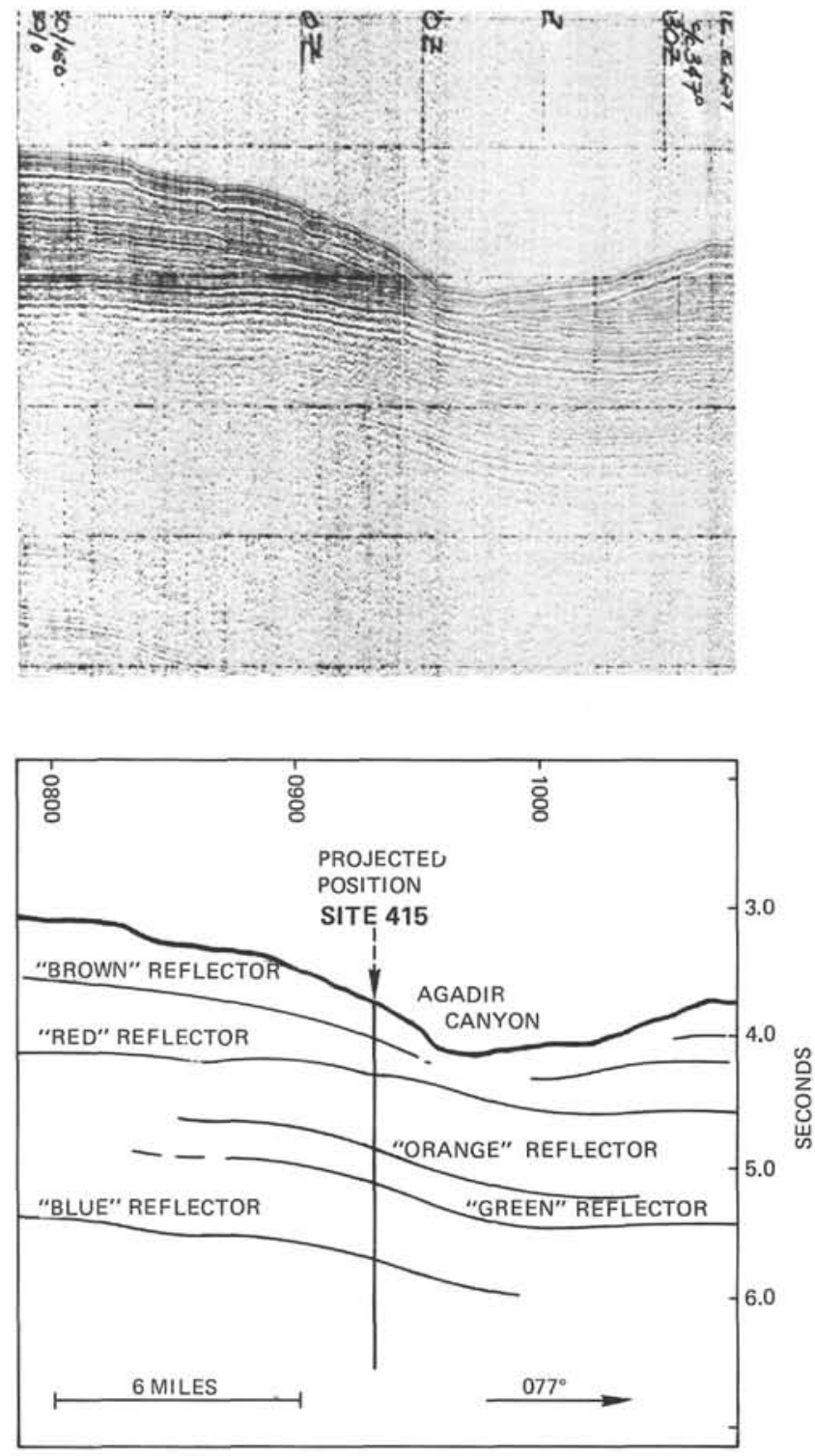

Figure 6. Seismic-reflection profile (low frequency, 10-80 Hz) obtained on the Glomar Challenger while approaching Site 415 on 13 September 1976. Site 415 is about 0.5 miles north of the projected position. See track on Figure 5.

from the cone, instead of having to discharge the cuttings out through the cone itself.

By 1225 on 21 September the down-hole transducer was positioned at 2807 meters below the derrick floor and we began our next re-entry attempt. At 1308 the target looked right, and the pipe was stabbed down. A great rattling was heard from the loudspeaker connected with the sonar probe, and the weight indicator wobbled a bit. The pipe was lowered 10 more meters with no indications of hitting anything, and we believed that the pipe was in the hole. But as we lowered more, the pipe took weight and we now suspected that we had missed the cone. To check on this, a core barrel was dropped and we cored the interval 2854.5 to 2864 meters. A few grams of gray mud were recovered with mixed Quater- nary and late-Pliocene fossils. Fearing contamination, we washed down another 9.5 meters and took another core from 2873.4 to 2881 meters. This core contained 3.1 meters of marl of the early Pliocene and proved beyond doubt that we were outside the cone. Evidently, we had struck the rim and rattled off onto the adjacent sea floor. The exercise was labeled Hole 415B, since samples had been obtained, and we withdrew to try again for re-entry.

By 2020 hours on 21 September, the sonar tool was poised off the sea floor at 2813.5 meters, and maneuvering began. At 0038 hours, after one miss, the pipe was stabbed into the cone and lowered to 2920 meters (103 m sub-bottom), where it began to take weight on account of the mud in the hole. Following a 1.5-hour delay caused by an electrical problem in the Bowen controls, the pipe was moved ahead to the top of the cement at 3132.5 meters and then drilled through the casing shoe at 3155 meters ( $338 \mathrm{~m}$ sub-bottom). The hole had been carried to 344.5 meters before re-entry, and we deepened this to 349 meters and took Core $415 \mathrm{~A}-1$, which recovered only $20 \mathrm{~cm}$ from 9.5 meters cored. A drift survey was run next, showing a deviation of less than 1 degree from the vertical. In retrieving the drift-survey tool, the regular port-side sand line jumped off its sheave, slacking the line and allowing it to twist. After attempting for 1.5 hours to make repairs, we put the sand line on the main draw-works into use.

After drilling ahead to 414.5 meters, another core was taken (415A-2), but the barrel returned empty. Core 415A-3 was taken immediately below Core 415A-2 and also yielded nothing. Concerned that something could be lodged in the throat of the bit, we lowered the extended core barrel and latched it in. This showed that the throat was clear, and coring resumed. Core $415 \mathrm{~A}-4$, immediately below Core $415 \mathrm{~A}-3$, returned only a handful of porcellanite chips from Paleocene, but it contained an almost miraculous gift: a cylinder of metal 6.5 $\mathrm{cm}$ across and $4 \mathrm{~cm}$ high, representing a major chunk of the metal cementing plug, drilled at the casing shoe. The plug is designed to be used with drilling bits, and could not be ground up by our coring bit. It had thus acted as a center bit-and a fairly effective one at that-during the drilling below the shoe.

Core 415A-5 was taken next below, from 443 to 452.5 meters sub-bottom, recovering 1.5 meters of Paleocene mudstone, with no signs of metal. The way was then clear, and we began a program of alternate drilling of six to eight single joints $(57-76 \mathrm{~m})$, then coring 9.5 meters, down through Core 415A-14 at 1041.5 meters sub-bottom. Drilling rates, using maximum pump volumes, averaged about $3 \mathrm{~min} / \mathrm{m}$, while coring rates, using much-reduced pumping rates, were mainly between 6 and $9 \mathrm{~min} / \mathrm{m}$. A drift survey at 718.5 meters subbottom showed a 1 degree deviation, but at 965 meters it was a little over 3 degrees. Another check at 1041.5 meters sub-bottom gave about 3.5 degrees.

Drilling continued until 1079.5 meters, where the pipe became stuck in the hole just after midnight on 26 September. All during the previous day, an increasing back flow was observed while making pipe connections 

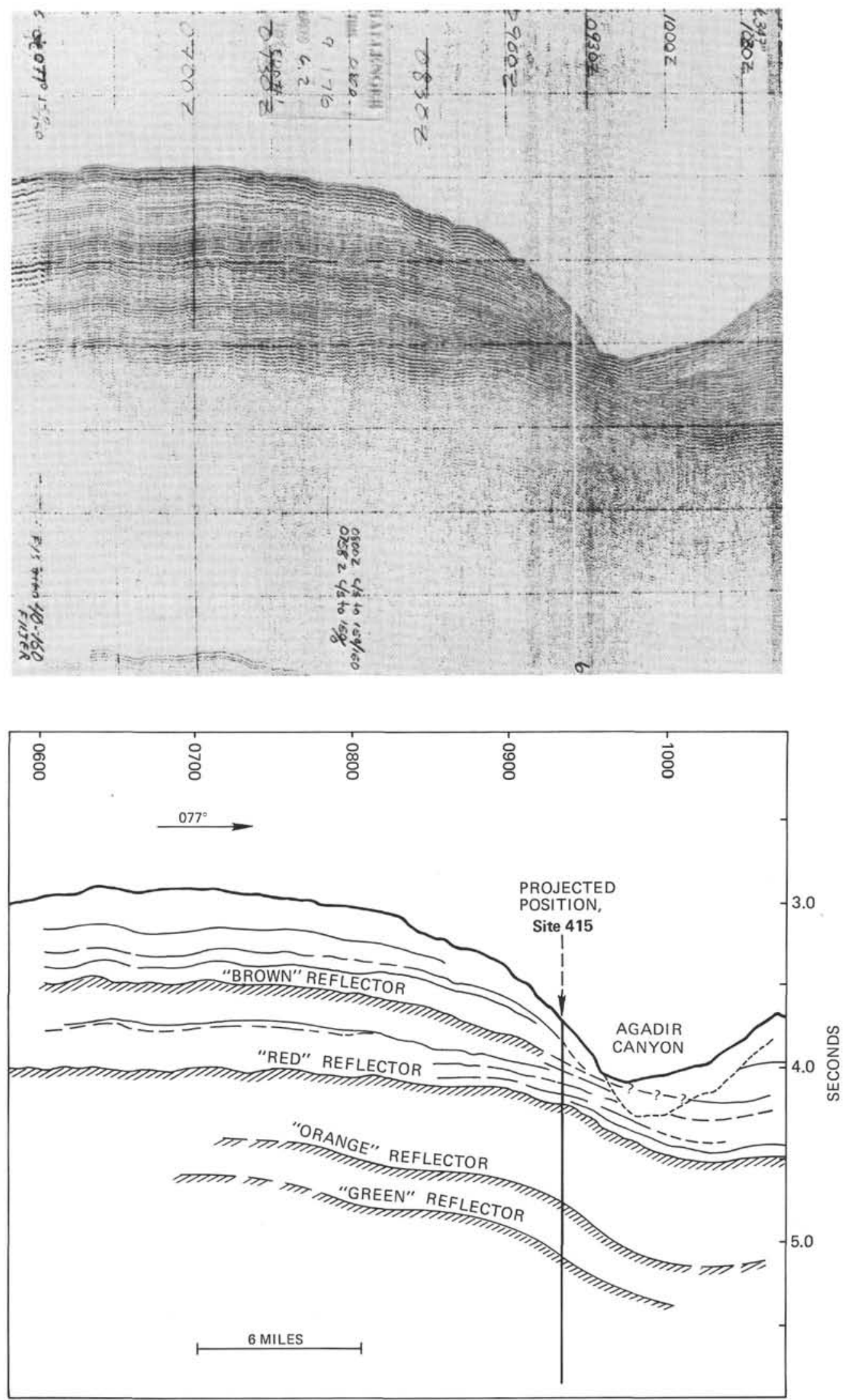

Figure 7. Seismic-reflection profile (high frequency, 40-160 Hz) obtained on the Glomar Challenger while approaching Site 415 on 13 September 1976. Site 415 is about 0.5 miles north of the projected position. See track on Figure 5. 
on the drill floor, suggesting an increasing column of cuttings in the annulus, but there were no signs of the pipe sticking. After spotting mud, the pipe was freed, and we began pulling out of the hole at 0450 hours on 26 September, in order to make up a new bottom-hole assembly and remove the diverter packoff assembly from the cone in the hope that it would improve the circulation of cuttings out of the hole, if indeed that was the major source of the difficulty. Core $415 \mathrm{~A}-14$, the last core, had recovered 2.2 meters of highly fractured and calcite-veined Cretaceous mudstone that may have been subbject to excessive caving. The bit was on deck at 1450 hours and close inspection showed that it was virtually in mint condition after about 45 hours of rotation.

After cutting out the damaged section of twisted sand line on the port side winch and making a long splice, the new bottom-hole assembly was made up; pipe was run in to a depth of 2815 meters, and the sonar tool was lowered. At 0513 hours on 27 September, the sonar was in place and searching for the cone for the third reentry.

Re-entry was successful, but it revealed some disturbing facts. The only clearly visible targets were the three small glass spheres which float 2 meters above the rim of the cone, although there was also one other poor reflector, which might have been one of the large steel reflectors on the rim. The glass spheres could only be seen with the sonar that looks down at an $8^{\circ}$ angle, not with the one at $45^{\circ}$. When the sonar was centered over the cone at $\mathbf{2 8 1 6}$ meters, the glass spheres were not more than about three meters away. These data suggest that the rim of the cone was at about 2818 or 2819 meters depth, which is at or below the surrounding sea floor. During the actual re-entry, at 0600 , no noise was heard, suggesting that the cone itself was at least partly filled with mud or cuttings. We were thus faced with the likelihood that our cone was lying with its rim almost even with or perhaps slightly below the sea floor, its main reflectors nearly buried, and its interior clogged with mud. The problem of keeping the hole clean was now greatly compounded by the problem of waste disposal at the surface.

The pipe ran into the hole without any resistance to a depth of about 530 meters, where cuttings in the hole required that we wash ahead and rotate the pipe. The Bowen power swivel was placed in the derrick, and the pipe was advanced to about 890 meters, where it started taking weight and resisting rotation. Progress slowed markedly, and the difficulties with rotation worsened with depth. At 1013 meters, the torque and weight suddenly dropped back to normal levels for a new hole, and we surmised that the bit may have been sidetracked from the previously drilled hole.

At 2115 hours on 27 September, the drill string was raised 100 meters to wipe and check on the condition of the hole. To raise the pipe was easy, but in lowering it again we met almost the same difficulties as before. Attempts to drill back to the bottom continued until 0800 hours on 28 September, but the bit never advanced beyond 1043 meters.
The situation was now critical. We believed that the troublesome interval was in highly fractured mudstones, similar to those recovered in Core 415A-14, and that these were continuing to cave in spite of efforts to stabilize the hole with mud and to circulate out the cuttings. A clogged cone resting nearly flush with the sea floor compounded the problem, and we concluded that further efforts in this hole probably would be futile. Even if we were to get past the caving shale, the cone problem would remain and probably become worse as we drilled deeper. Thus, the decision was made to abandon the hole.

Because our seismic-reflection-profile records indicated that the same fractured and caving formation was very widespread, we judged it imprudent to start again in the vicinity of Site 415 , for even if there were a properly placed cone we were very likely to meet the same bad down-hole conditions. Therefore, the decision was made to go to our alternate site, near Site 370 , about 110 miles northeast of Site 415 .

Before pulling out of Hole 415A, a gamma-ray log was run from within the drill pipe to try to extract additional information from this hole. The bit could not safely be run below 908 meters, but the logging run from there to the surface was completely successful and yielded vital clues to the succession of strata at the site. A further bit of information fell into our hands as the logging device emerged through the cone: the cone was filled to 2817 meters with material with high gamma radiation, suggesting cuttings from the Cretaceous, rather than mud from the surface sediments on the sea floor.

By 1615 hours on 29 September, the logging tools were back on deck. Two hundred barrels of bariteweighted mud were placed in the hole, and the drill string was recovered. At 2305 hours, the ship was under way from Site 415 to the area of Site 370 .

\section{Hole 415B}

As set out in the operations narrative for Hole 415A, the drilling of Hole 415B was the unintentional result of missing the cone on a re-entry attempt on 21 September, just after setting casing.

The stab into the sea floor next to the cone at Hole $415 \mathrm{~A}$ was made at 1308 hours on 21 September, and it is assumed for bookkeeping purposes that the bit entered the sea floor at 2817 meters below the derrick floor. This estimate may be shallow by several meters if there was a depression around the cone. It is also likely that the pipe entered the sea floor at an angle, so that the precise depth of the cores below the sea floor is further confused. The depths given are simply the length of drill pipe measured from the derrick floor. Details of the history of coring at Hole 415B are included in the narrative for Hole 415A. Two cores were taken, and a theoretical "total depth" of 64 meters was attained.

Operations at this hole were concluded at 1900 hours on 21 September, when the pipe was pulled just clear of the sea floor to attempt another re-entry at Hole 415A. 
An inventory of the cores recovered in the three successive holes appears in Table 1.

\section{LITHOLOGIC SUMMARY}

Six major lithologic units were sampled, units I to V in the Cenozoic section and unit VI in the Cretaceous (Table 2). Because the main objective at this site was to study the Jurassic sequence, and because the site was relatively near a site drilled previously (Site 370 ), only 15 widely spaced cores were taken throughout the Cenozoic and Cretaceous sections. Because only 4.7 per cent of this cored section was recovered, it is difficult to define the lithologic units very precisely. In general the boundaries between lithologic units fall between cores, in an unsampled interval typically 60 to 70 meters thick. We have therefore estimated depths to the lithologic boundaries using down-hole logs (gamma-ray, sonicvelocity, bulk-density, dual-induction, etc.) and the drilling rates, as shown on the graphic hole summary (Figure 8)*.

Determinations of calcium-carbonate content are reported in Table 3.

Smear-slide data are shown in Figure 9*, as well as on the graphic descriptions for each core. Thin-section data are reported in Table 4 and shipboard coarsefraction data are given in Table 5 .

\section{Lithologic Units}

Unit I: Nannofossil marl and nannofossil ooze. Cores 415-1, 415-2, 415B-1, and 415B-2; 0 to 110 meters, Pleistocene to upper Miocene.

* To facilitate comparison with core-description sheets, Figures 8 and 9 are placed at the end of the chapter.
Our information about the upper part of the sedimentary column is scanty. Coring in this unit was sparse, recovery was generally poor, and the cores were highly disturbed by the drilling process. The surface core (415-1), from 0 to 7.5 meters, is olive-gray and light-brown nannofossil marl, consisting of about 50 per cent clay and 50 per cent calcareous planktonic fossils. Nannofossils predominate over foraminifers, except in a few thin layers. Pteropods are present in the topmost part of this core. Core 415B-2 (56.5-64 meters) is more calcareous $\left(\sim 70 \% \mathrm{CaCO}_{3}\right)$ and is pinkish gray, and Core $415-2(74-83.5 \mathrm{~m})$ is clayey to marly at the top and calcareous at the bottom. Silt-size quartz and mica grains and tiny dark specks of authigenic pyrite make up a few per cent of unit I.

Except for a few sponge spicules (and in Core 415-2 rare diatoms and radiolarians), siliceous microfossils are absent. Benthic foraminifers, ostracodes, mollusk fragments, and echinoid spines are present but rare. Planktonic foraminifers are preserved unfragmented at the top of Core 415-1, but the degree of fragmentation increases to about 25 per cent in Core 415-2.

The only sedimentary structures discernible through the drilling disturbances are burrow mottles and a few sharp contacts between more-clayey and more-calcareous beds in Core 415-2.

Unit II: Alternating marl and nannofossil chalk. Core $415-3$; 110 to 199 meters. Upper to middle Miocene.

Unit II is differentiated from Unit I by its greater induration and by an obvious alternation of light-olivegray and light-gray layers on a scale of 5 to $10 \mathrm{~cm}$. The boundary between Units I and II is arbitrarily placed midway between Cores 415-2 and 415-3, at 110 meters.

TABLE 1

Coring Summary, Site 415

\begin{tabular}{|c|c|c|c|c|c|c|c|}
\hline & Date & & $\begin{array}{l}\text { Depth From } \\
\text { Drill Floor } \\
\text { (m) } \\
\text { Top Bottom }\end{array}$ & $\begin{array}{l}\text { Depth Below } \\
\text { Sea Floor } \\
(\mathrm{m})\end{array}$ & $\begin{array}{l}\text { Length } \\
\text { Cored }\end{array}$ & Recovery & Recovery \\
\hline Core ivo. & Date & ime & Bottom & Bottom & & & \\
\hline $415-1$ & $14 / 9 / 76$ & 0916 & $2817-2824.5$ & $0-7.5$ & 7.5 & 9 & 120 \\
\hline 2 & $14 / 9 / 76$ & 1744 & $2891-2900.5$ & $74-83.5$ & 9.5 & 2.4 & 26 \\
\hline 3 & $15 / 9 / 76$ & 0105 & $2954.5-2964$ & $137.5-147$ & 9.5 & 4.08 & 43 \\
\hline 4 & $15 / 9 / 76$ & 0808 & $3024-3033.5$ & 207-216.5 & 9.5 & 7.5 & 79 \\
\hline 5 & $15 / 9 / 76$ & 1415 & $3090.5-3100$ & $273.5-283$ & 9.5 & 8.3 & 87 \\
\hline 415B-1 & $21 / 9 / 76$ & 1600 & $2854.5-2864$ & $37.5-46$ & 9.5 & 0.01 & 1 \\
\hline 2 & $21 / 9 / 76$ & 1800 & $2873.5-2881$ & $56.5-64$ & 7.5 & 3.09 & 4.1 \\
\hline $415 \mathrm{~A}-1$ & $22 / 9 / 76$ & 1721 & $3166-3174.5$ & $349-357.5$ & 8.5 & 0.2 & 2 \\
\hline 2 & $23 / 9 / 76$ & 0053 & $3231.5-3241$ & $414.5-424$ & 9.5 & 0 & 0 \\
\hline 3 & $23 / 9 / 76$ & 0323 & $3241-3250.5$ & $424-433.5$ & 9.5 & 0 & 0 \\
\hline 4 & $23 / 9 / 76$ & 0700 & $3250.5-3260$ & $433.5-443$ & 9.5 & 0.05 & 1 \\
\hline 5 & $23 / 9 / 76$ & 0915 & $3260-3269.5$ & $443-452.5$ & 9.5 & 1.5 & 16 \\
\hline 6 & $23 / 9 / 76$ & 1537 & $3269.5-3326.5$ & $452.5-509.5$ & 57 & 3.3 & - \\
\hline 7 & $23 / 9 / 76$ & 1750 & $3326.5-3336$ & $509.5-519$ & 9.5 & 0.6 & 6 \\
\hline 8 & $24 / 9 / 76$ & 0003 & $3393-3402.5$ & $576-585.5$ & 9.5 & 3.0 & 32 \\
\hline 9 & $24 / 9 / 76$ & 0800 & $3459.5-3469$ & $642.5-652$ & 9.5 & 6.9 & 73 \\
\hline 10 & $24 / 9 / 76$ & 1605 & $3526-3535.5$ & $709-718.5$ & 9.5 & 2.0 & 21 \\
\hline 11 & $24 / 9 / 76$ & 2320 & $3611.5-3621$ & $794.5-804$ & 9.5 & 2.6 & 27 \\
\hline 12 & $25 / 9 / 76$ & 0520 & $3697-3706.5$ & $880-889.5$ & 9.5 & 2.9 & 30 \\
\hline 13 & $25 / 9 / 76$ & 1135 & $3773-3782.5$ & $956-965.5$ & 9.5 & 2.6 & 27 \\
\hline 14 & $25 / 9 / 76$ & 1830 & $3849-3858.5$ & $1032-1041.5$ & 9.5 & 2.2 & 23 \\
\hline 15 & $26 / 9 / 76$ & 1445 & $3858.5-3896.5$ & $1041.5-1079.5$ & 38 & 0.4 & - \\
\hline
\end{tabular}


TABLE 2

Lithologic Units at Site 415 (Holes 415, 415A, and 415B)

\begin{tabular}{|c|c|c|c|c|c|}
\hline Unit & Lithology & $\begin{array}{l}\text { Down-Hole Log Features } \\
\text { At Upper Unit Boundaries }\end{array}$ & Cores & $\begin{array}{l}\text { Depth Below } \\
\text { Sea Floor } \\
\text { (m) }\end{array}$ & Age \\
\hline I & $\begin{array}{l}\text { Nannofossil marl and } \\
\text { nannofossil ooze }\end{array}$ & No $\log$ & $\begin{array}{l}415-1 \text { to } 2 \\
415 B 1 \text { to } 2\end{array}$ & $0-110$ & $\begin{array}{l}\text { Late Miocene to } \\
\text { Pleistocene }\end{array}$ \\
\hline II & $\begin{array}{r}\text { Alternating marl and } \\
\text { nannofossil chalk }\end{array}$ & & $415-3$ & $110-199$ & Middle to late Miocene \\
\hline III & $\begin{array}{l}\text { Alternating nannofossil chalk } \\
\text { and siliceous-debris- } \\
\text { bearing marl }\end{array}$ & $\begin{array}{l}\text { Change from high } \gamma, \text { low } e \\
\text { and low } v \text { to fluctuating } \\
\text { high and low values of } \gamma \text {, } \\
e \text { and } v \text { at about } 199 \text { meters }\end{array}$ & $415-4$ to 5 & $199-313$ & $\begin{array}{l}\text { Early and middle } \\
\text { Miocene }\end{array}$ \\
\hline IV & $\begin{array}{l}\text { Mudstone with interbeds } \\
\text { of gravel, sandstone, } \\
\text { and chalk(?) }\end{array}$ & $\begin{array}{l}\gamma \text { increase and slow-down in } \\
\text { drilling rate at } 313 \text { meters }\end{array}$ & $\begin{array}{l}415 \mathrm{~A}-1 \text { to } 6 \\
\text { Sec. } 1,7 \mathrm{~cm}\end{array}$ & $313-476.5$ & $\begin{array}{l}\text { Late Paleocene to early } \\
\text { Eocene }\end{array}$ \\
\hline $\mathrm{V}$ & $\begin{array}{l}\text { Marlstone with intercalations } \\
\text { of nannofossil chalk and } \\
\text { limestone }\end{array}$ & Low $\gamma$ & $415 A-6$ & $476.5-491$ & $\begin{array}{l}\text { Early and late } \\
\text { Paleocene }\end{array}$ \\
\hline VIa & Mudstone & $\begin{array}{l}\text { Very strong } \gamma \text { peak at } \\
491 \text { meters }\end{array}$ & $415 \mathrm{~A}-7$ & $491-551$ & $\begin{array}{l}\text { Middle Cretaceous } \\
\text { (between Albian and } \\
\text { Coniacian) }\end{array}$ \\
\hline $\mathrm{VIb}$ & $\begin{array}{l}\text { Mudstone, marlstone, and } \\
\text { limestone }\end{array}$ & $\begin{array}{l}\text { Top of cyclic sequence at } \\
551 \text { meters; monotonous } \\
\text { high- } \gamma \text { response from } 758 \\
\text { to } 1008 \text { (end of log) }\end{array}$ & $415 \mathrm{~A}-8$ to 14 & $551-1041.5$ & $\begin{array}{l}\text { Late Albian to middle } \\
\text { Cenomanian }\end{array}$ \\
\hline VIc & Marlstone and calcarenite & & $415 \mathrm{~A}-15$ & $1041.5-1079.5$ & Late Albian \\
\hline
\end{tabular}

There is no apparent log response to the boundary between Units I and II. The boundary between Units II and III, which lies somewhere between Cores 415-3 and 415-4 (147-207 m), is likely at about 199 meters, where a change in the general character of the down-hole logs suggests a change from less-indurated marl and ooze to alternating more- and less-indurated marl and chalk or limestone (see section on physical properties and well logging in this chapter). Core 415-3, although somewhat disturbed by the drilling process, shows clear burrow mottles, especially in Section 3. The alternating lighter (more-calcareous) and darker (more-marly) layers generally have diffuse contacts.

The marly layers contain 35 to 45 per cent clay (mainly smectite and illite; see Chamley et al., this volume), while the more-calcareous layers contain as much as 85 per cent calcite. Nannofossils constitute almost the whole of the calcareous component. Planktonic foraminifers make up only 3 to 10 per cent of the sediment, and from 25 to 50 per cent of these are fragmented by dissolution. Radiolarians, diatoms, and sponge spicules are present but rare. Silt-size quartz grains are generally present in amounts less than 2 per cent. Coarse fractions also contain occasional rare grains of glauconite, and a few benthic foraminifers.
Unit III: Alternating nannofossil chalk and siliceousdebris-bearing marl. Cores 415-4 and 415-5; 199 to 313 meters. Middle and lower Miocene.

This unit differs from unit II in (1) being better indurated; (2) showing well-developed alternations (on a scale of tens of centimeters) of marly, grayish-green layers and chalky, pale-gray, greenish-gray, and lightgray layers; and (3) having a few coquina layers, consisting mainly of displaced shallow-water fossils (Core 415-5), and a bed of silicified calcarenite pebbles (Core $415-5, \mathrm{CC})$. There is a marked increase in the proportion of siliceous biogenic material in Core 415-5 (5-25\%) as compared to $415-4$ and to the overlying units I and II. The base of unit III is placed at a level ( 31.3 meters) where the drilling rate increased, and where there is a sharp increase in gamma radiation on the log.

The marly layers are generally 10 to $20 \mathrm{~cm}$ thick and alternate with more-chalky layers 40 to $200 \mathrm{~cm}$ thick. There is commonly a zone 5 to $10 \mathrm{~cm}$ thick of intensive mixing of the two types of material at contacts. Burrowing is the cause of this mixing and has obliterated most original bedding features (Figure 10). Burrows containing dark-green marl are abundant throughout both cores, but are particularly well developed in the darker marly layers. Zoophycos are well developed, particular- 
TABLE 3

Calcium-Carbonate Determinations for Site 415

\begin{tabular}{|c|c|c|c|}
\hline \multirow[b]{2}{*}{$\begin{array}{c}\text { Sample } \\
\text { (interval in } \mathrm{cm} \text { ) }\end{array}$} & \multicolumn{3}{|c|}{$\mathrm{CaCO}_{3}(\%)$} \\
\hline & $\begin{array}{c}\text { Shipboard } \\
\text { Carbonate } \\
\text { Bomb }\end{array}$ & $\begin{array}{l}\text { DSDP } \\
\text { Leco } \\
\text { WR-12 }\end{array}$ & $\begin{array}{c}\text { Bernard } \\
\text { Calcimeter } \\
\text { (data of } \\
\text { M. Melguen) }\end{array}$ \\
\hline $415-1-1,17-18$ & & 58 & \\
\hline $1-1,30-31$ & 51 & & \\
\hline $1-1,75-76$ & 51 & & \\
\hline $1-1,80-82$ & & & 58.5 \\
\hline $1-1,82-84$ & & & 57 \\
\hline $1-1,120-122$ & & & 50.5 \\
\hline $1-4,130-132$ & & & 41.0 \\
\hline $1-5,102-104$ & & & 57.5 \\
\hline $2-1,93-96$ & & & 58.5 \\
\hline $2-1,99-100$ & 66.5 & & \\
\hline $2-1,101-102$ & & 68 & \\
\hline $3-1,30-31$ & 69.5 & & \\
\hline $3-1,60-62$ & & & 65.5 \\
\hline $3-1,88-90$ & & 66 & \\
\hline $3-2,123-125$ & & & 59.0 \\
\hline $3-3,50-52$ & & & 54.5 \\
\hline $3-3,80-82$ & & & 79.0 \\
\hline $4-1,32-34$ & & & 69.5 \\
\hline $4-1,41-42$ & & 74 & \\
\hline $4-1,68-70$ & & & 51.0 \\
\hline $4-1,73-75$ & 67.5 & & \\
\hline $4-1,133-135$ & 63.5 & & \\
\hline $4-2,30-32$ & & & 29.0 \\
\hline $4-2,70-72$ & & & 62.3 \\
\hline $4-5,54-56$ & & & 25.0 \\
\hline $4-5,62-63$ & 33.0 & & \\
\hline $4-5,102-103$ & & & 69.5 \\
\hline $4-5,106-108$ & & & 73.5 \\
\hline $5-1,30-32$ & & & 52.0 \\
\hline $5-1,100-102$ & & & 38.1 \\
\hline $5-1,120-121$ & $56.5,67.0$ & & \\
\hline $5-3,50-52$ & & & 27.0 \\
\hline $5-4,30-32$ & 79 & & \\
\hline $5-4,65-67$ & & & 48.0 \\
\hline $5-4,67-69$ & & & 46.5 \\
\hline $5-5,92-93$ & 44 & & \\
\hline $5-6,25-27$ & & & 55.0 \\
\hline $5-6,41-43$ & & & 43.0 \\
\hline $5-6,60-62$ & 63.5 & & \\
\hline $415 \mathrm{~A}-5-1,34-35$ & & 0 & \\
\hline $5-1,53-54$ & 4 & & \\
\hline $5-1,129-131$ & & & 2.5 \\
\hline $5, \mathrm{CC}$ & 9 & & \\
\hline $6-1,20-21$ & 42.5 & & \\
\hline $6-1,72-74$ & & & 84. \\
\hline $6-1,110-112$ & & & 55. \\
\hline $6-1,148-149$ & 68 & & \\
\hline $6-2,8-10$ & & & 49.0 \\
\hline $6-2,37-39$ & & & 63.5 \\
\hline $7-1,26-28$ & & & 3. \\
\hline
\end{tabular}

ly in the chalky layers (Figure 11). The more-chalky layers consist of about 50 to 70 per cent calcareous nannofossils, 20 to 40 per cent clay (mainly smectite and illite), 5 to 15 per cent siliceous fossils, 2 to 10 per cent planktonic foraminifers, and 1 to 2 per cent quartz. The marly layers consist of about 30 to 45 per cent clay, 40 to 50 per cent calcareous nannofossils, 10 to 25 per cent siliceous fossils, 1 to 2 per cent planktonic foraminifers, and a few per cent quartz. The marly layers are thus richer than the chalky layers in siliceous remains and de-
TABLE 3 - Continued

\begin{tabular}{|c|c|c|c|}
\hline \multirow[b]{2}{*}{$\begin{array}{c}\text { Sample } \\
\text { (interval in cm) }\end{array}$} & \multicolumn{3}{|c|}{$\mathrm{CaCO}_{3}(\%)$} \\
\hline & $\begin{array}{c}\text { Shipboard } \\
\text { Carbonate } \\
\text { Bomb }\end{array}$ & $\begin{array}{l}\text { DSDP } \\
\text { Leco } \\
\text { WR-12 }\end{array}$ & $\begin{array}{l}\text { Bernard } \\
\text { Calcimeter } \\
\text { (data of } \\
\text { M. Melguen) }\end{array}$ \\
\hline $\begin{array}{c}415 \mathrm{~A}-8-2,36-37 \\
8-2,103-104 \\
9-1,91-92 \\
9-1,92-94 \\
9-3,71-72 \\
9-3,76-78 \\
9-4,54-55 \\
9, \mathrm{CC} \\
9, \mathrm{CC} 7-8 \\
11-1,6-8 \\
11-1,50-52 \\
11-1,120-123 \\
11, \mathrm{CC} 5-7 \\
12-1,111-113 \\
12-2,2-3 \\
12-2,113-115 \\
13-1,100-101 \\
13-1,128-130 \\
14-1,25-27 \\
14-1,120-121 \\
14, \mathrm{CC} 14-16 \\
15-1,19-20\end{array}$ & $\begin{array}{l}19 \\
85 \\
35.5 \\
38 .\end{array}$ & 38 & $\begin{array}{l}28.8 \\
27.2 \\
\\
25.6 \\
\\
56.8 \\
34.4\end{array}$ \\
\hline $\begin{array}{c}415 \mathrm{~B}-2-1,42-48 \\
2-1,50-51 \\
2-1,90-91 \\
2-1,100-101 \\
2-1,120-122 \\
2-2,30-31 \\
2-2,70-72 \\
2-2,100-101\end{array}$ & $\begin{array}{l}70 \\
62 \\
71 \\
73\end{array}$ & 72 & $\begin{array}{r}67.9 \\
70.3\end{array}$ \\
\hline
\end{tabular}

trital quartz, and are poorer in planktonic foraminifers. Authigenic pyrite is present in nearly all samples, but is more abundant in the darker marly layers.

Fragmentation of planktonic foraminifers ranges from 5 to 25 per cent, and is highest in the darker-colored marly layers.

In 415-4-5, the coquina layer (Figure 12) consists mainly of long tubules $(0.15 \mathrm{~mm}$ wide, $1-4 \mathrm{~mm}$ long), some of which have chambers. These tubules resemble bryozoans. Additional components are mollusk fragments (mainly pelecypods), planktonic foraminifers, echinoderm fragments, angular quartz grains, glauconite, and lumps of calcareous mud. All these components are partly cemented by sparry calcite, and coated with a dusting of tiny pyrite crystals that imparts a medium-gray color to the bed.

Other coarse textures occur in Core 415-4 at several levels where angular bits of dark chert and rounded grains of glauconite and clear quartz are both preserved in simple burrows and dispersed through multiple crisscrossing burrows (Figure 13).

The core-catcher of Core 415-5 contains a few angular pebbles of silicified calcarenite (Figure 14).

Unit IV: Mudstone, probably with intercalated sandstone and conglomerate, and perhaps chert. Cores $415 \mathrm{~A}-1$ through $415 \mathrm{~A}-6$, Section 1,0 to $7 \mathrm{~cm} ; 313$ to 476.5 meters. Lower Eocene to upper Paleocene. 
We have only a few scraps of core material from which to infer the lithology of this unit: Core $415 \mathrm{~A}-1$ is only $19 \mathrm{~cm}$ long, Cores $415 \mathrm{~A}-2$ and $415 \mathrm{~A}-3$ were empty, and Core 415-4 recovered almost nothing. Core 415A-5 recovered 1.6 meters, and Core 6 is hard to place, because it represents a composite of 57 meters of section. Between 313 meters and $\mathbf{4 7 6 . 5}$ meters lies an interval of higher gamma radiation. The sharp increase at 313 meters seems the logical boundary between the chalks of unit III and the underlying, more-terrigenous unit IV. In addition, the drilling rate fluctuated considerably, from about 2 to $6 \mathrm{~m} / \mathrm{min}$, in this part of the hole (Figure 8 ), suggesting that the lithology may not be uniform. Low rates first began at about 313 meters, which is therefore chosen as the top of unit IV. The lowest rates were between about 335 and 365 meters, which includes the pebbles sampled in Core 415A-1. Because of the presence of a piece of metallic junk in the hole over the interval 338 to 443 meters, the drilling rates may not be geologically significant.

Core $415 \mathrm{~A}-1$ contained pebbles 3 to $5 \mathrm{~cm}$ in diameter (Figure 15) and a few centimeters of yellowish-brown mud. Six of the pebbles are sub-rounded and thus are inferred to be from a gravel layer. They are siltstone and sandstone pebbles consisting of rounded quartz grains in a chert matrix. The seventh pebble is angular and consists of yellowish-brown porcellanite showing a conchoidal fracture and sub-vitreous luster. Small, angular grains of this same rock type are embedded in the underlying mud. It is possible that the porcellanite fragments come from a chert interbed in the drilled sequence. The yellowish-brown fragment is calcareous and includes streaks of nannofossil marl. Core 415A-5 and the upper $7 \mathrm{~cm}$ of Core 415A-6 consist of dusky-green to grayishblue-green, fine silty and clayey mudstone, with intercalations of greenish-black, laminated, highly burrowed mudstone. Burrows and laminae are most abundant in $415 \mathrm{~A}-5-1,0$ to $70 \mathrm{~cm}$. Zoophycos are mainly restricted to the greenish-black mud, while Chondrites are common throughout. The mudstone consists of about 90 per cent clay ( $90 \%$ smectite, $10 \%$ attapulgite), with 3 to 5 per cent accessory detrital quartz and a few per cent authigenic pyrite. Coarse fractions from the mud of Core 415A-1 contain benthic foraminifers, planktonic foraminifers, and quartz grains in about equal proportions, and about 5 per cent fish debris, but no siliceous microfossils. By contrast, coarse fractions of the mudstone of Core $415 \mathrm{~A}-5$ contain up to 25 per cent siliceous fossils (mainly radiolarians) and 50 per cent planktonic foraminifers, but only a few per cent each of benthic foraminifers, fish debris, and quartz. A possibly resedimented layer occurs in the top part of 415A-6-1, where deformed, elongate, soft sediment clasts up to $1 \mathrm{~cm}$ long include large $(2 \mathrm{~mm})$, thick-walled benthic foraminifers.

Planktonic foraminifers are about 30 per cent fragmented in Core $415 \mathrm{~A}-1$, but only 5 per cent fragmented in Core 415A-5.

The gamma-ray log suggests two sequences in unit IV, each with a progressive upward decrease in clay content, separated by an interval from 365 to 383 meters in which clay decreases upward. Given the seemingly clastic nature of unit IV, the log can be interpreted as indicating two coarsening-upward sequences (increasing sand content), suggesting a progradation. The gravel clasts of Core $415 \mathrm{~A}-1$ probably represent the upper part of the higher sequence.

Unit V: Marlstone with intercalations of nannofossil chalk and limestone. Core 415A-6 (except for uppermost $7 \mathrm{~cm}$ of Section 1); 476.5 to 491 meters. Upper and lower Paleocene.

Core 415A-6, below $7 \mathrm{~cm}$ in Section 1, belongs entirely to unit V. The chalky sediments of unit V, seen in Core $415 \mathrm{~A}-6$, must come from somewhere in the 57meter interval over which the core barrel was open for this core. On the log, the most likely interval is between 476.5 and 491 meters, which interval has the lowest gamma-ray count in the entire cored sequence. The few pieces of mudstone from 0 to $7 \mathrm{~cm}$ in $415 \mathrm{~A}-6-1$ are lithologically like the mudstone of unit IV and are assigned to that unit. They may come from any level in the 57 meters cored, above the chalks of unit V. At a depth of 491 meters, the gamma-ray log peaks very strongly, suggesting an anomalously high concentration of radioactive materials (phosphorite?) and thus a possible unconformity between units V and VI.

Core 415A-6 consists of light-olive-gray to greenishgray marlstone, with layers of light-greenish-gray nannofossil chalk which is marly (except for one layer; Section 1, 62-69 cm), containing up to 70 per cent nannofossils (Figure 16).

Laminae, including flaser-like laminae, are abundant throughout Core 415A-6, but especially in Section 2 (Figure 17). Deformation features (microfolds, microslumps, and shear planes) are encountered here for the first time at Site 415 (Figure 18). The effects of bioturbation are evident at many levels in the core, but they are not abundant or pervasive.

A large $(2-\mathrm{cm})$ pyrite nodule was lodged in the core catcher of 415A-6.

The marlstone consists of about 60 per cent clay ( $90 \%$ smectite, $10 \%$ attapulgite), 25 to 30 per cent calcareous nannofossils, and 10 per cent calcite and 1 per cent dolomite rhombs. The chalky layers are similar, except for a higher proportion of calcareous nannofossils.

Coarse fractions contain planktonic foraminifers $(50 \%)$, benthic foraminifers $(20 \%)$, radiolarians $(10 \%)$, quartz $(10 \%)$, and minor amounts of diatoms, fish debris, glauconite, and echinoid remains.

Unit VI: Claystone and dolomitic shale with intervals of marlstone, dolomite, and limestone. Core 415A-7 through $415 \mathrm{~A}-15$; 491 to 1041.5 meters. Cenomanian to upper Albian.

Because coring was very discontinuous and recovery was only modest, we have only 23.2 meters of core material on which to base inferences about 590 meters of section. The only down-hole log is the gamma-ray log, taken through the drill pipe over the upper 406 meters of unit VI. The cores show that the dominant rock type in unit VI is calcareous or dolomitic shale, accompanied by marlstone and marly limestone and dolomite. Quartzose calcarenite occurs in Cores 415A-14 and $415 \mathrm{~A}-15$. There is direct evidence in the cores of 
TABLE 4

Sediment Texture and Composition from Thin Sections, Hole 415A

\begin{tabular}{|c|c|c|c|c|c|c|c|c|c|c|c|}
\hline \multirow[b]{2}{*}{$\begin{array}{c}\text { Sample } \\
\text { (interval in } \mathrm{cm} \text { ) }\end{array}$} & \multicolumn{3}{|c|}{ Texture (\%) } & \multicolumn{8}{|c|}{ Biogenic Components (\%) } \\
\hline & Sand & Silt & Clay & $\begin{array}{l}\text { Benthic } \\
\text { Fora- } \\
\text { minifers }\end{array}$ & $\begin{array}{l}\text { Planktonic } \\
\text { Fora- } \\
\text { minifers }\end{array}$ & $\begin{array}{l}\text { Calc. } \\
\text { Nanno- } \\
\text { fossils }\end{array}$ & Diatoms & $\begin{array}{l}\text { Radio- } \\
\text { larians }\end{array}$ & $\begin{array}{l}\text { Sponge } \\
\text { Spicules }\end{array}$ & $\begin{array}{l}\text { Silico- } \\
\text { flagellates }\end{array}$ & $\begin{array}{c}\text { Fish } \\
\text { Debris }\end{array}$ \\
\hline $415 \mathrm{~A}-1, \mathrm{CC}$ (clast \#1) & 1 & 60 & 40 & - & - & - & - & - & - & - & - \\
\hline $1, \mathrm{CC}($ clast \#2) & 50 & 10 & 40 & - & - & - & - & - & - & - & - \\
\hline $1, \mathrm{CC}$ (clast \#5) & - & 30 & 70 & - & - & - & - & - & - & - & - \\
\hline $1, \mathrm{CC}$ (clast \#6) & 5 & 65 & 30 & 5 & - & - & - & - & 1 & - & - \\
\hline 1,CC (clast \#7) & 1 & 5 & 95 & - & $1-2$ & - & - & $1-2$ & 1 & - & - \\
\hline $4, \mathrm{CC}, 13-17$ & 5 & $>10$ & $>85$ & - & - & - & - & 2 & - & - & - \\
\hline $7-1,25$ & tr & tr & $>95$ & - & - & - & - & 2 & - & - & - \\
\hline $8, C C, 12-14$ & 5 & 80 & 10 & - & - & - & - & - & - & - & - \\
\hline $11-2,38-40$ & $<1$ & 35 & 65 & - & - & - & - & - & - & - & - \\
\hline $11, \mathrm{CC}, 24-26$ & - & - & - & - & - & - & - & - & - & - & - \\
\hline $12-1,102-103$ & - & - & - & - & - & - & - & tr & - & - & - \\
\hline $12, \mathrm{CC}, 15-16$ & 10 & 40 & 50 & - & - & - & - & - & $\operatorname{tr}$ & - & - \\
\hline $13-1,67$ & 1 & 9 & 90 & - & tr & tr & - & - & - & - & - \\
\hline $13-1,96-97$ & - & 50 & 50 & - & - & - & - & - & - & - & - \\
\hline $13-1,120$ & - & 70 & 30 & - & - & - & - & - & $\operatorname{tr}$ & - & - \\
\hline $14-1,63$ & - & 20 & 80 & - & - & - & - & - & - & - & - \\
\hline 14 (cuttings) & - & - & - & - & - & - & - & - & - & - & - \\
\hline $15-1,11-13$ & - & - & - & - & - & - & - & - & - & - & - \\
\hline $15, \mathrm{CC}, 0-5$ & 80 & 20 & - & - & - & - & - & - & - & - & - \\
\hline
\end{tabular}

creep and down-slope slipping of the sediments, and cycles observed on the gamma-ray log suggest postdepositional tectonic repetitions of the stratigraphic section.

Three lithologic subdivisions have been recognized, based partly on the cores themselves and partly on the gamma-ray log:

1. Sub-unit VIa: 491 to 551 meters (Core 415A-7).

The core is olive-gray to grayish-green mudstone, nearly carbonate-free. The clay is about 90 per cent smectite and 10 per cent attapulgite. Coarse fractions show an abundance of fish debris and zeolite-filled and -replaced radiolarians. Strong dissolution is suggested by this lithology.

The log shows irregular fluctuations, suggesting alternations of clayey and limey sediments, although the clay predominates.

2. Sub-unit VIb: 551 to 1041.5 meters (Cores $415 \mathrm{~A}-8$ through 415A-14).

The major part of this sub-unit consists of olivegreen and dark-greenish-gray mudstone, with intervals of olive-gray and gray-green calcareous mudstone, marlstone, and limestone, much disturbed by diagenetic deformation of depositional structures by creep and slumping.

The mudstone consists mainly of smectite, with a few per cent of kaolinite and attapulgite, except for $415 \mathrm{~A}$ 10-1, which contains about 35 per cent attapulgite. A few per cent silt-size quartz generally occurs in the mudstone.

The carbonate is mainly neomorphic $(20-30 \mu \mathrm{m})$ calcite spar (Figures 19 and 20) and rhombic ferroan dolomite microspar (5-15 $\mu \mathrm{m})$. In some layers, staining indicated non-ferroan dolomite, possibly ankerite and ferroan dolomite. Calcareous nannofossils and foraminifers, although present, probably contribute less than 5 per cent to the total carbonate; the remainder is apparently diagenetic carbonate. Total carbonate content, based on bomb analyses, ranges from 6 per cent (mudstone) to 85 per cent (limestone).
Other authigenic minerals include pyrite, which is present in small amounts throughout the core but is more abundant in the carbonate-poor rocks. The best examples occur in 415A-8-1, where pyrite nodules which grew in the mudstone display intergrown octahedrons as much as $2 \mathrm{~cm}$ in diameter. Crystals of anhydrite as much as $1.5 \mathrm{~cm}$ across are scattered in a marly-dolomite matrix in $415 \mathrm{~A}-13-1,120-130 \mathrm{~cm}$; they contain inclusions of dolomite rhombs and have ragged outlines, indicating replacement growth after dolomitization.

Lamination (Figure 21) on a millimeter to centimeter scale is common. It is present in all rock types but is best preserved in the marlstones and shales (where fissility is not too great). Typically, it is wavy or flasery, and it is commonly deformed by early diagenetic creep.

Even, parallel laminae are rather rare. They are best developed in Core 415A-10 (Figure 21), where they form graded beds 1 to $4 \mathrm{~cm}$ thick with a thin $(1-\mathrm{mm})$ basal layer of fine sand overlain by marlstone that grades up to lighter-colored crystalline limestone. The upper, limestone parts of these laminae are burrowed.

Relatively undisturbed depositional laminae are also preserved in parts of Core 415A-14. These show neither grading nor any other vertical polarity. The layers are generally thinner (a few $\mathrm{mm}$ to $2 \mathrm{~cm}$ ) than the graded units of Core 415A-10 and consist of light, carbonaterich, and of dark, organic-rich clay layers. In one place, this lamination shows indistinct, low-angle, lens-type cross-bedding and channeling (Figure 22), indicating traction deposition.

Bioturbation is less intensive than in the Cenozoic section, and well-preserved burrows are rare, except for Chondrites at the top of the graded units in Core $415 \mathrm{~A}-10$.

Limestone beds generally appear massive, but original depositional laminations may have been destroyed during diagenesis. Relics of clay laminae may be seen in thin sections of some limestone layers. Some mudstone intervals are also massive, but lamination may have been destroyed by fluidization during slumping. The 
TABLE 4 - Continued

\begin{tabular}{|c|c|c|c|c|c|c|c|c|c|c|c|c|c|}
\hline \multicolumn{5}{|c|}{ Terrigenous Components (\%) } & \multicolumn{6}{|c|}{ Authigenic Components (\%) } & \multirow[b]{2}{*}{$\begin{array}{c}\text { Calcite } \\
(\%)\end{array}$} & \multirow[b]{2}{*}{$\begin{array}{c}\text { Volcanic } \\
\text { Glass } \\
(\%)\end{array}$} & \multirow[b]{2}{*}{ Remarks } \\
\hline Clay & $\begin{array}{l}\text { Heavy } \\
\text { Minerals }\end{array}$ & Quartz & Micas & $\begin{array}{l}\text { Lithic } \\
\text { Grains }\end{array}$ & Pyrite & $\begin{array}{l}\text { Other } \\
\text { Opaque } \\
\text { Minerals }\end{array}$ & $\begin{array}{l}\text { Calcite and } \\
\text { Dolomite } \\
\text { Rhombs }\end{array}$ & Zeolites & Chert & $\begin{array}{l}\text { Glauco- } \\
\text { nite }\end{array}$ & & & \\
\hline 40 & $1-2$ & 40 & $<1$ & 2 & - & - & - & - & - & $8-10$ & - & 5 & Derived clast \\
\hline$<15$ & 5 & $>50$ & - & - & - & - & - & - & 30 & - & - & 1 & Bimodal-congl. clast \\
\hline 70 & - & 15 & - & $\sim$ & - & - & - & - & - & $5-10$ & - & $5-10$ & Siltstone clast \\
\hline 30 & 1 & 30 & 2 & 30 & - & - & - & - & 10 & - & $1-3$ & 1 & Siltstone clast \\
\hline 15 & - & 1 & - & - & - & - & - & - & $75-80$ & 5 & - & - & Porcellanite nodule \\
\hline 20 & - & tr & $\mathrm{tr}$ & - & - & 3 & - & - & $>70$ & 3 & 5 & - & Silicified hemipelagic chert grain \\
\hline- & 1 & 1 & - & - & - & 1 & - & - & $>95$ & - & - & - & Radiolarians totally silicified \\
\hline 5 & - & - & - & - & 1 & - & - & - & - & 1 & 90 & - & Recryst. limestone \\
\hline 60 & - & - & - & - & $<1$ & - & - & - & - & - & 40 & - & Recryst. marlstone \\
\hline $5-10$ & $<1$ & $<1$ & - & - & 1 & - & 90 & - & - & - & $1-3$ & - & Dolomite \\
\hline 95 & - & $\sim 1$ & - & - & 2 & - & $\mathrm{tr}$ & - & - & - & $<1$ & - & Shale \\
\hline 50 & - & 10 & - & - & 2 & - & - & - & - & 1 & - & - & $10 \%$ skeletal fragments \\
\hline 90 & - & - & - & - & 1 & - & - & - & - & - & 5 & - & Shale or mudstone \\
\hline 45 & - & 2 & - & - & 1 & - & 50 & - & - & - & - & - & Dolomite marlstone \\
\hline 30 & - & 1 & - & - & 2 & - & 60 & - & - & - & - & - & \\
\hline 80 & - & 1 & - & $=$ & 1 & - & 10 & - & - & - & 1 & - & Shale, various carbonates \\
\hline 5 & - & $2-3$ & - & 25 & - & - & - & - & - & - & - & - & Lithic grains are skeletal fragments \\
\hline 90 & - & $1-3$ & - & - & - & - & $1-3$ & - & - & - & 5 & - & Shale, with dolomite calcite \\
\hline- & - & 15 & - & 45 & tr & - & - & - & - & - & 40 & - & Lithic grains are skeletal fragments \\
\hline
\end{tabular}

12-cm-thick calcarenite bed in Core 415A-15 has welldeveloped parallel laminations throughout.

There is abundant evidence for early diagenetic plastic deformation (creep and slumping) of sedimentary layers. In Cores 415A-8 through 415A-14, the depositional laminae are crinkled by microfolds with amplitudes of a few millimeters and are dissected by shear planes with offsets of a few millimeters. Bedding surfaces in large parts of the cores are tilted as much as $45^{\circ}$. The disturbance of primary depositional layering is most intensive in Core 415A-9, where folds with amplitudes of at least $30 \mathrm{~cm}$ can be inferred from direct observation of the cores (Figure 23). Core 415A-14 shows the only example of brittle fracturing, indicated by calcitefilled veins in calcareous shale. The main fractures are subvertical, with associated "en echelon" tensional cracks dipping 10 to $30^{\circ}$. The highest fracture density is 2 to 3 per centimeter.

3. Sub-unit VIc: 1041.5 to 1079.5 meters (Core 415A-15).

Core $415 \mathrm{~A}-15$ differs from the overlying beds by the very even, practically undeformed lamination in the greenish-black marlstone, and by the occurrence of a $10-\mathrm{cm}$ layer of well-cemented, grayish-green calcarenite containing shallow-water carbonate detritus. A few pieces of calcarenite were also found among the cavings which accumulated in the hole after the cutting of Core $415 \mathrm{~A}-14$, and so we place the top of sub-unit VIc at 1041 to 1045 meters, which is the base of the interval cored in Core 415A-14.

The calcarenite consists of well-sorted, abundant, sand-size, benthic foraminifers; common fragments of mollusk shells and echinoderm ossicles; and a few phosphatic fish-bone fragments; all cemented by sparry calcite.

\section{ORGANIC GEOCHEMISTRY}

In Hole 415A, we expected to core a greater thickness of sediments than ever before encountered in DSDP history. Thus, there arose a unique opportunity to see the pattern of long geochemical evolution of organic substances under the conditions of a continental rise. The hole was expected to reach depths at which organic matter probably would be able to generate liquid hydrocarbons. Apart from its scientific significance, this hole thus also posed special problems of pollution prevention and safety, and the shipboard program of geochemical study was therefore designed to provide immediately available information for safety purposes.

Since hydrocarbon generation is a natural and inevitable result of the maturation of buried organic matter, the safety objective was reduced to distinguishing the imminent accumulation of hydrocarbons against the background of normal increase in hydrocarbon content with depth. For this purpose it was necessary (1) to estimate the current capacity of the organic matter to generate hydrocarbons, and (2) to compare this estimate with the actual presence of hydrocarbons, taking into account factors that could promote their migration and accumulation.

The Cenozoic section at Site 415 shows low gas concentrations (Table 6, Figure 24). Down to a sub-bottom depth of 450 meters (Core 415A-5), only methane is present in measurable amounts. Ethane was first recorded at a depth of 443 to 452 meters, and it maintained the same level of concentration $(50-80 \mathrm{ppm})$ throughout the Cenozoic sequence. Hydrocarbons heavier than ethane were absent until the lowest part of the Cenozoic section (452-509.5 meters), where propane appeared. Then, in a gas sample taken from a core which spanned the transition interval between Cenozoic and Cretaceous, heavy hydrocarbons including the isomers of butane and pentane were found in appreciable concentrations.

In contrast to the Cenozoic, the Cretaceous shows noticeable concentrations of heavy homologs of methane.

Downward from the top of the Cretaceous, $\mathrm{C}_{1} / \mathrm{C}_{2}{ }^{+}$ and $\mathrm{C}_{2} / \mathrm{C}_{3}$ ratios steadily decrease (Figure 24). The $\mathrm{C}_{3} /(i+n) \mathrm{C}_{4}$ ratio parallels the $\mathrm{C}_{1} / \mathrm{C}_{2}{ }^{+}$ratio. 
TABLE 5

Composition of Sediment Coarse Fraction, Site 415

\begin{tabular}{|c|c|c|c|c|c|c|c|c|c|c|c|c|}
\hline \multirow[b]{2}{*}{$\begin{array}{c}\text { Sample } \\
\text { (interval in } \mathrm{cm} \text { ) }\end{array}$} & \multicolumn{12}{|c|}{ Biogenic Components (\%) } \\
\hline & Bivalves & $\begin{array}{l}\text { Echino- } \\
\text { derms }\end{array}$ & $\begin{array}{l}\text { Ostra- } \\
\text { codes }\end{array}$ & $\begin{array}{l}\text { Ptero- } \\
\text { pods }\end{array}$ & $\begin{array}{l}\text { Benthic } \\
\text { Fora- } \\
\text { minifers }\end{array}$ & $\begin{array}{l}\text { Planktonic } \\
\text { Fora- } \\
\text { minifers }\end{array}$ & $\begin{array}{l}\text { Fragmented } \\
\text { Planktonic } \\
\text { Foraminifers }\end{array}$ & Diatoms & $\begin{array}{l}\text { Radio- } \\
\text { larians }\end{array}$ & $\begin{array}{l}\text { Sponge } \\
\text { Spicules }\end{array}$ & $\begin{array}{c}\text { Silico- } \\
\text { flagellates }\end{array}$ & $\begin{array}{c}\text { Fish } \\
\text { Debris }\end{array}$ \\
\hline $415-1-1,4-6$ & $1-2$ & tr & $<1$ & 5 & 2 & 90 & $5-10$ & - & 1 & 1 & - & - \\
\hline $1-1,127-129$ & $1-2$ & tr & $<1$ & - & 2 & 90 & $5-10$ & - & 1 & 1 & - & - \\
\hline $1-4,107-109$ & $1-2$ & $\mathrm{tr}$ & $<1$ & - & 2 & 95 & $5-10$ & - & - & 1 & - & tr \\
\hline $2-1,102-104$ & - & - & - & - & $<1$ & 90 & 20 & - & 2 & 2 & - & 3 \\
\hline $2-2,35-37$ & - & - & - & - & $<2$ & 85 & 40 & - & 1 & 1 & - & $1-2$ \\
\hline $2, \mathrm{CC}$ & - & 3 & - & - & 5 & 80 & 30 & - & 3 & 1 & - & 3 \\
\hline $3-1,25-27$ & - & 2 & tr & - & 5 & 40 & 30 & - & 10 & 2 & - & $2-3$ \\
\hline $3-2,54-56$ & - & 1 & - & - & $3-5$ & 80 & 25 & 1 & $5-7$ & 2 & - & 1 \\
\hline $3-3,36-38$ & - & - & tr & - & $2-3$ & 85 & 30 & - & 5 & 3 & - & $2-3$ \\
\hline $3, \mathrm{CC}$ & - & - & - & - & 1 & 80 & 10 & - & $2-3$ & 2 & - & $<1$ \\
\hline $4-1,36-38$ & - & 2 & - & - & $2-3$ & 85 & 10 & - & $1-2$ & $1-2$ & - & 2 \\
\hline $4-2,38-40$ & - & $<1$ & - & - & 1 & 10 & $30-40$ & - & 10 & 2 & - & 1 \\
\hline $4-3,71-73$ & - & - & - & - & $<2$ & 75 & $5-10$ & - & $3-5$ & 2 & - & $<1$ \\
\hline $4-4,91-93$ & - & - & 1 & - & 5 & 5 & $5-10$ & - & $10-15$ & 3 & - & 1 \\
\hline $4-5,60-62$ & $1-2$ & $<1$ & - & - & 2 & $10-15$ & 20 & - & $10-15$ & $3-5$ & - & - \\
\hline $4, \mathrm{CC}$ & 1 & 2 & 1 & - & 3 & 55 & 10 & - & 10 & 2 & - & $1-2$ \\
\hline $5-1,97-99$ & - & - & - & - & 10 & $3-5$ & $10-20$ & - & $10-15$ & $3-5$ & - & $1-2$ \\
\hline $5 \cdot 2,58-60$ & - & 1 & - & - & 5 & 40 & 5 & - & 25 & 1 & - & 1 \\
\hline $5-3,98-100$ & - & $<1$ & - & - & $1-2$ & 50 & $10-20$ & - & $25-30$ & 2 & - & $i$ \\
\hline $5-4,47-49$ & - & - & $<1$ & - & $<1$ & 70 & $5-10$ & - & $15-20$ & 2 & - & $1-2$ \\
\hline $5-5,89-91$ & - & $\mathrm{tr}$ & $<1$ & - & $5-7$ & 20 & 30 & - & 10 & - & - & 3 \\
\hline $5, \mathrm{CC}$ & - & - & - & - & - & 80 & 20 & - & $5-7$ & $1-2$ & - & 1 \\
\hline $415 \mathrm{~A}-1, \mathrm{CC}$ & - & - & 2 & - & 25 & 20 & 30 & - & - & - & - & $5-7$ \\
\hline $1, \mathrm{CC}$ & - & - & 1 & - & 25 & 20 & $20-30$ & - & - & - & - & $3-5$ \\
\hline $4, \mathrm{CC}$ & - & - & - & - & - & $<1$ & - & - & 5 & $<1$ & - & - \\
\hline $5-1,19-21$ & - & - & - & - & - & $\mathrm{tr}$ & - & - & 30 & 1 & - & - \\
\hline $5 . \mathrm{CC} 11-13$ & - & - & - & - & - & - & - & - & 15 & - & - & - \\
\hline $6-1,70-72$ & 2 & $\leqslant 1$ & $2-3$ & - & 15 & 35 & $<2$ & - & $5-10$ & - & - & $3-5$ \\
\hline $6-1,119-121$ & - & $1-2$ & $1-2$ & - & 20 & $15 \cdot 20$ & $<10$ & - & 5 & - & - & 5 \\
\hline $6-2,25-27$ & - & - & $1-2$ & - & 30 & 40 & $<10$ & - & 10 & - & - & 3 \\
\hline $6, C \subset 7-9$ & - & - & - & - & 10 & 65 & 5 & - & - & - & - & $3-5$ \\
\hline $7-1,21-23$ & - & - & - & - & tr & 2 & 100 & - & - & - & - & 10 \\
\hline $7, \mathrm{CC} 5-7$ & - & - & - & - & - & $-\operatorname{tr}$ & 100 & - & 20 & - & - & 20 \\
\hline $415 B-2-1,12-14$ & - & $<1$ & - & - & $3-5$ & 90 & 20 & - & - & - & - & 2 \\
\hline $2-1,140-142$ & - & $\leqslant 1$ & - & - & $<2$ & 97 & $\leqslant 10$ & - & - & - & - & $<1$ \\
\hline $2-1,32-34$ & - & $<1$ & - & - & $\leqslant 2$ & 97 & $<10$ & - & - & - & - & $<1$ \\
\hline $2-2,36-38$ & - & - & - & - & $<1$ & 98 & $\leqslant 10$ & - & - & - & - & $<1$ \\
\hline $2-2,80-82$ & - & - & - & - & $\leqslant 1$ & 98 & 20 & - & - & - & - & $<1$ \\
\hline $2-2,118-120$ & - & - & - & - & $7-10$ & 90 & 25 & - & - & - & - & $<1$ \\
\hline $2, \mathrm{CC} 4-6$ & - & - & - & - & $7-10$ & 90 & 25 & - & - & - & - & $<1$ \\
\hline
\end{tabular}

On the basis of pyrolysis data (Table 7), the upper part of the sequence, from the sea floor to 300 meters, is characterized by a very low potential hydrocarbon content and immature organic matter. An additional peak on the pyrolysis diagram between 300 and $360^{\circ} \mathrm{C}$, just before the $\mathrm{S}_{2}$ peak $\left(400^{\circ} \mathrm{C}\right)$, is characteristic of living higher plants and the organic matter of certain modern coastal sediments (Boutefeu, in prep.).

From 400 to 800 meters, the indexes of potential hydrocarbons and generated hydrocarbons increase a little. Finally, from 850 meters to the bottom of the hole, the generated-hydrocarbons index continues to increase but the potential-hydrocarbon index decreases. The organic matter in all investigated samples belongs to the detrital, immature type.

The data in Table 7 show no clear-cut trend or differentiation in organic-carbon concentrations. The average concentration of organic carbon over the sequence investigated is 0.6 per cent. Cenozoic samples have slightly less organic carbon $(0.4 \%)$, while the samples from the upper part of the Cretaceous (Cores 415A-8 and $415 \mathrm{~A}-9)$ are slightly enriched in organic carbon $(1.06 \%$ avg.).

The carbonate content, averaging all the samples together, is rather high, especially in the upper part of the Cenozoic section, where it averages 52 per cent, but samples from the lower part of the Cenozoic (415A-5-1,
415A-5, CC, 415A-7, CC) have very low carbonate contents $(1.0-6.5 \%)$.

As can be seen in Table 7, the $\mathrm{C} / \mathrm{N}$ ratio of the Cenozoic sediments at Site 415 increases with depth of burial. This may indicate progressive diagenetic change in the organic matter of these sediments from the Pleistocene down to the lower-Miocene, and it also suggests that these Cenozoic sediments were deposited in similar environments. There is a fair correlation between the $\mathrm{C} / \mathrm{N}$ ratio and the carbonate content. This fact is an argument in favor of environmental control of the observed $\mathrm{C} / \mathrm{N}$ ratio.

In the lower Miocene, some thin, dark layers were encountered (415A-5-1) which showed comparatively high concentrations of organic carbon $(2.27 \%)$. This section is also distinguished by a relatively high potentialhydrocarbon index $\left(\mathrm{S}_{2}=8.4\right)$.

\section{INORGANIC GEOCHEMISTRY}

Chemical composition of interstitial water has been determined by techniques described in the introductory chapter of this volume. The data are presented in Figure 25.

In the upper 300 meters of the sequence, there are slight changes with depth in the measured parameters. The decrease in $\mathrm{Mg}^{++}$, with a concomitant increase in $\mathrm{Ca}^{++}$, is probably the result of ion-exchange reactions 
TABLE 5 - Continued

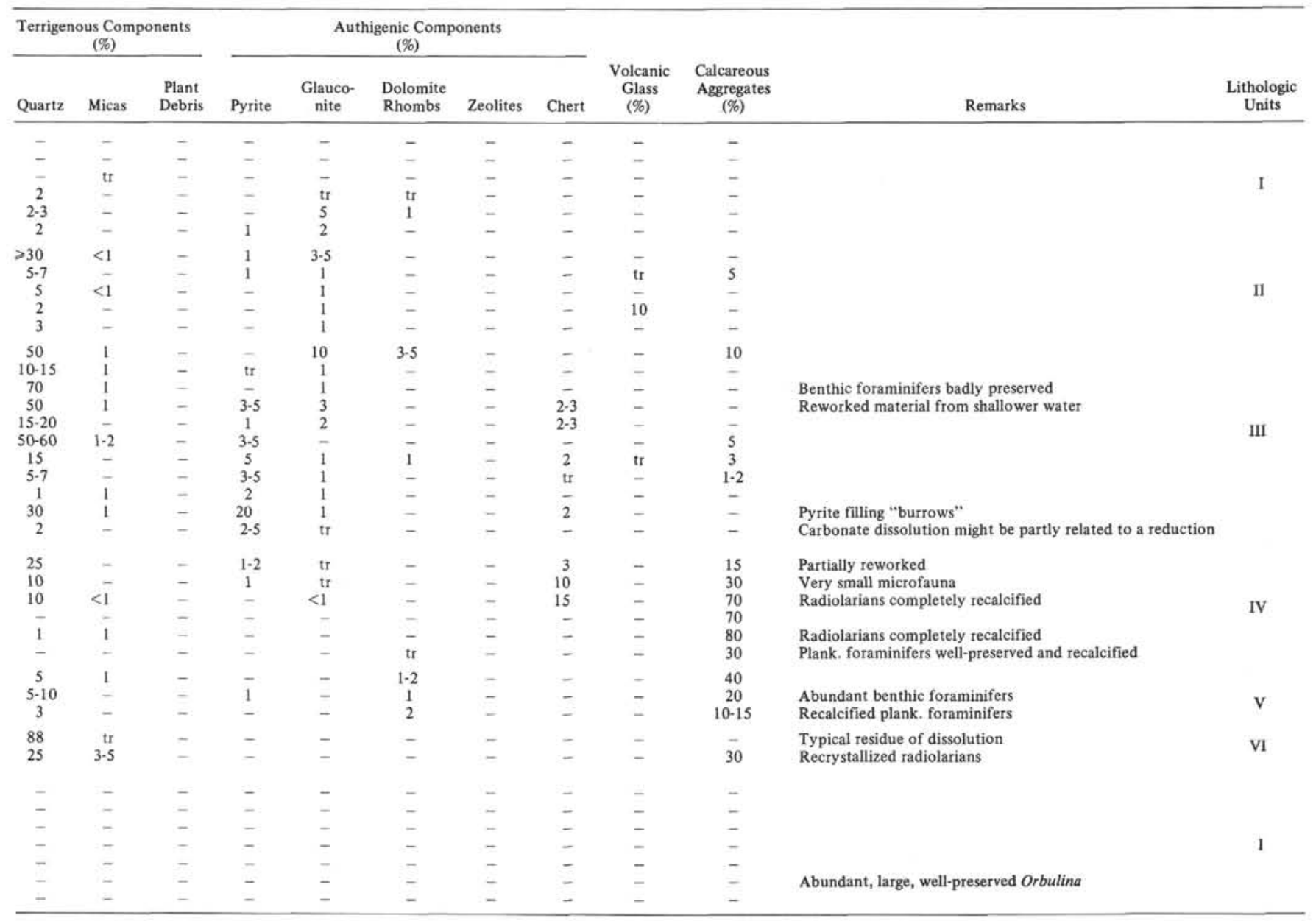

during diagenetic dolomitization. In general, the pattern of interstitial-water chemistry at the top of the Cenozoic sequence is quite consistent with the idea of normal diagenesis of predominantly biogenic sediments.

There is a gap in the data between 280 and 580 meters, where a parallel increase in $\mathrm{Mg}^{+}+$and $\mathrm{Ca}++$ occurs, accompanied by a decrease in $p \mathrm{H}$, possibly indicating dissolution of carbonate.

Below the top of the Cretaceous sequence, the trend of $\mathrm{Mg}^{++}$reverses and becomes again antithetical to the continuous downward increase in $\mathrm{Ca}^{++}$content. In the same interval there is an increase in $p \mathrm{H}$ and a reduction in salinity (see discussion in Gieskes et al., this volume).

\section{PHYSICAL PROPERTIES AND WELL-LOGGING MEASUREMENTS}

Wet-bulk density, wet-water content, porosity, compressional-sound velocity, and acoustic impedance were routinely determined on each core, where such measurements were feasible; the data are listed in Table 8 and presented in small-scale plots (Figures 26 and 27) and large-scale plots (Figures 28 and 29).

In addition, where the proper lithologic prerequisites were met (undisturbed clay), vane shear-strength measurements were attempted. Heat-conductivity measure- ments were attempted on soft cores, but the equipment was not working properly until after the beginning of coring operations at Hole 415A. Because only a few of these shear-strength and heat-conductivity measurements were made, the data are presented only in the text. Definitions and methodology of the laboratory physical properties are presented in Appendix 1 of this volume, and Schlumberger Well Log definitions and methods are discussed in Appendix 2. All laboratory physical properties are reported at ambient laboratory pressures and temperatures (unless otherwise stated), and all laboratory density, water-content, and porosity data are corrected for a median salinity of 45 per mill.

Because the geologic section was spot cored at 50 meter to 70-meter depth intervals, the laboratory measurements give only the most general trends. In addition, where the cores were disturbed, the physical properties, except for analog GRAPE wet-bulk density (see core plots), were not measured. (See core plots preceding core-description sheets at the end of this chapter.)

\section{Shear Strength}

Of the four attempts to measure shear strength of the clayey sediments of Hole 415 by vane shear techniques, only that for a green claystone from a depth of about 78 


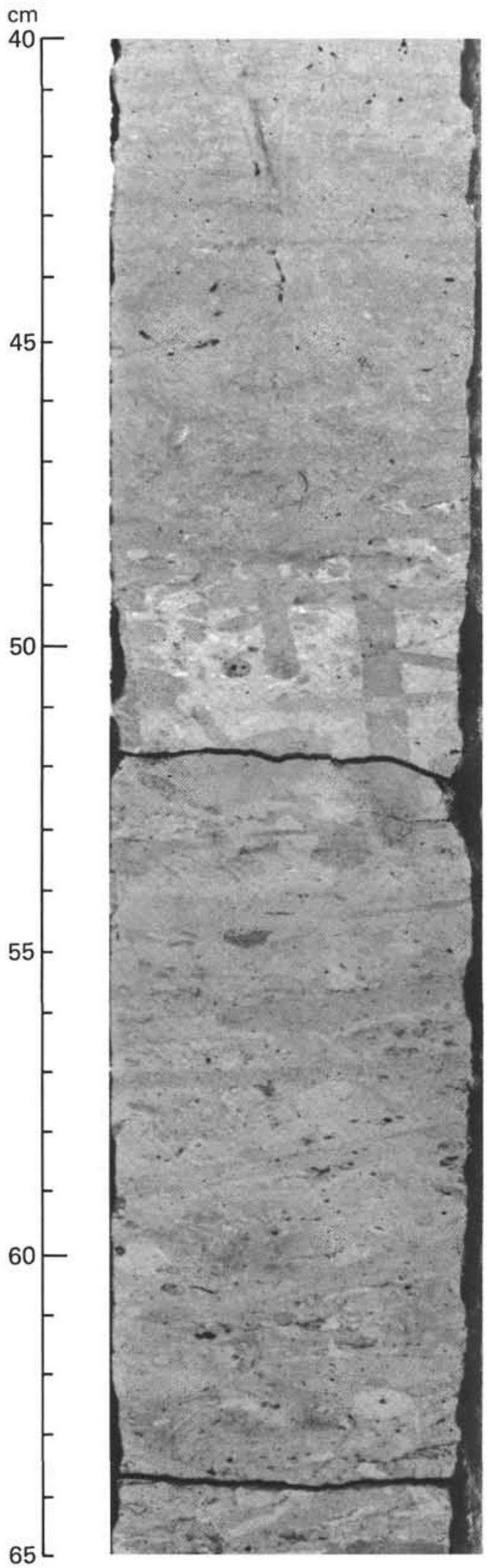

Figure 10. Burrows in foraminifer-nannofossil chalk (light colored) and marly chalk (darker colored), producing a blurring of lithologic boundaries. 415-5-2, 40-64 cm; lower Miocene.

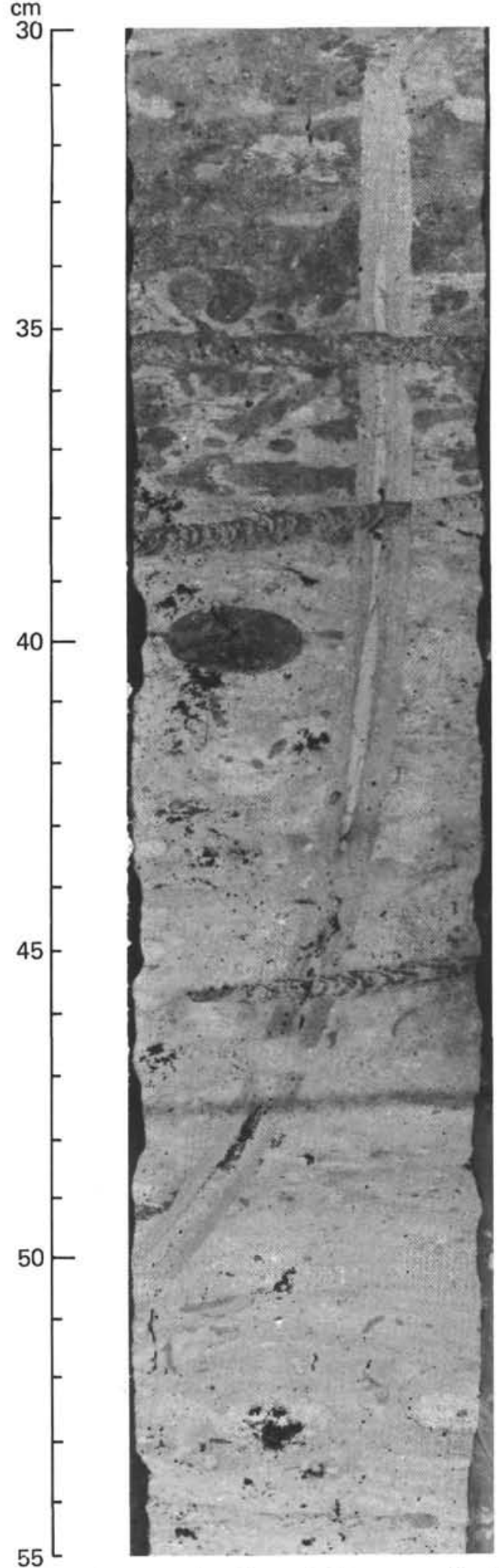

Figure 11. Burrows in foraminifer-nannofossil chalk (light colored) and marly chalk (darker colored). Horizontal Zoophycos, small Chondrites, and a long, vertical, composite burrow, which is transected by several Zoophycos burrows. 415-5-2, 30-52 cm; lower Miocene. 
$\mathrm{cm}$

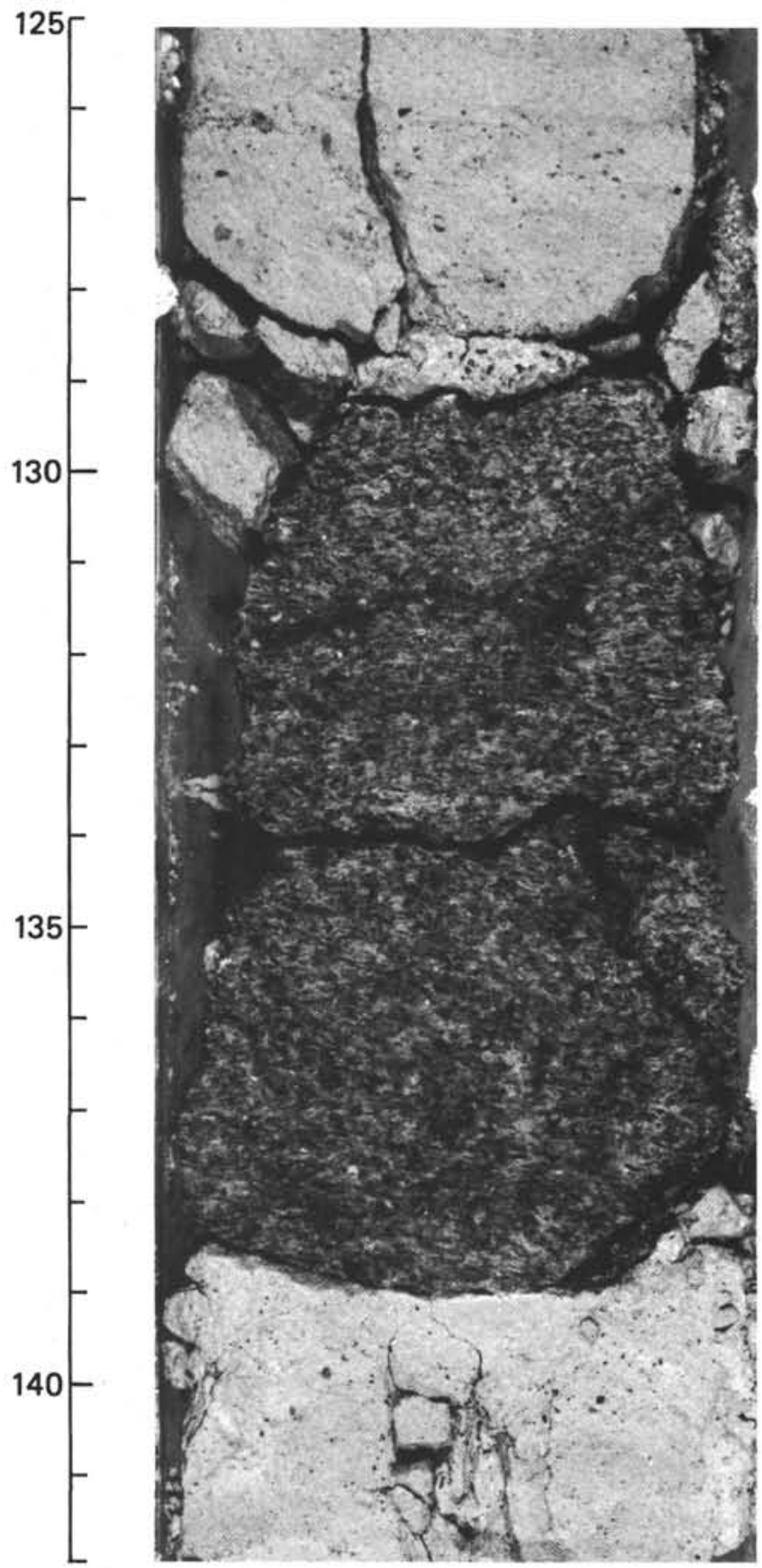

Figure 12. Coquina bed. The layer consists of a porous, redeposited fossil hash, comprising mainly tubules (bryozoans?) 1 to $4 \mathrm{~mm}$ long and about $0.15 \mathrm{~mm}$ thick, along with fragments of mollusks and echinoderms, plus planktonic foraminifers, quartz and glauconite, cemented by sparry calcite and coated with pyrite, which gives the layer its dark color. 415-4-5, 125-142 cm; lower Miocene.

meters was successful. This sample, which had a wetbulk density of $1.75 \mathrm{~g} / \mathrm{cm}^{3}$, a wet-water content of 34 per cent, and a porosity of 60 per cent, had a shear strength of $0.572 \mathrm{~kg} / \mathrm{cm}^{2}$ and a remolded strength of

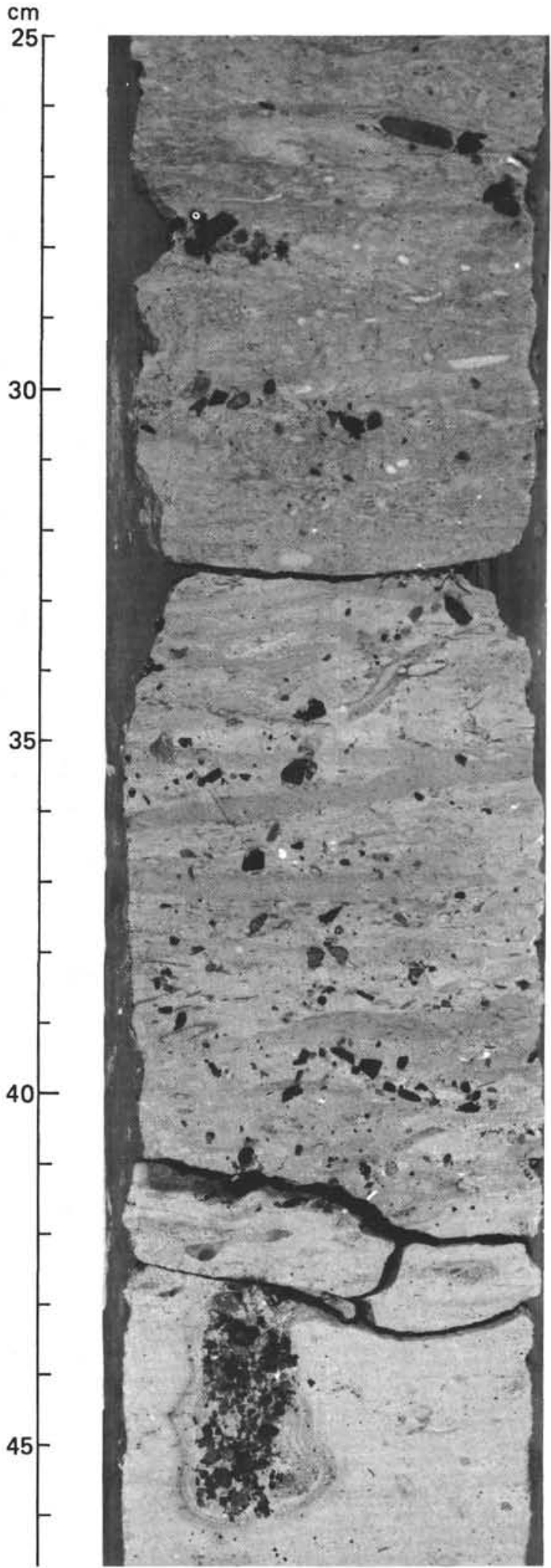

Figure 13. Dark-colored, angular grains of chert, concentrated in a burrow (bottom), dispersed by multiple burrows (center), and preserved in more or less intact beds (top). 415-4-2, 25-47 cm; middle Miocene. 

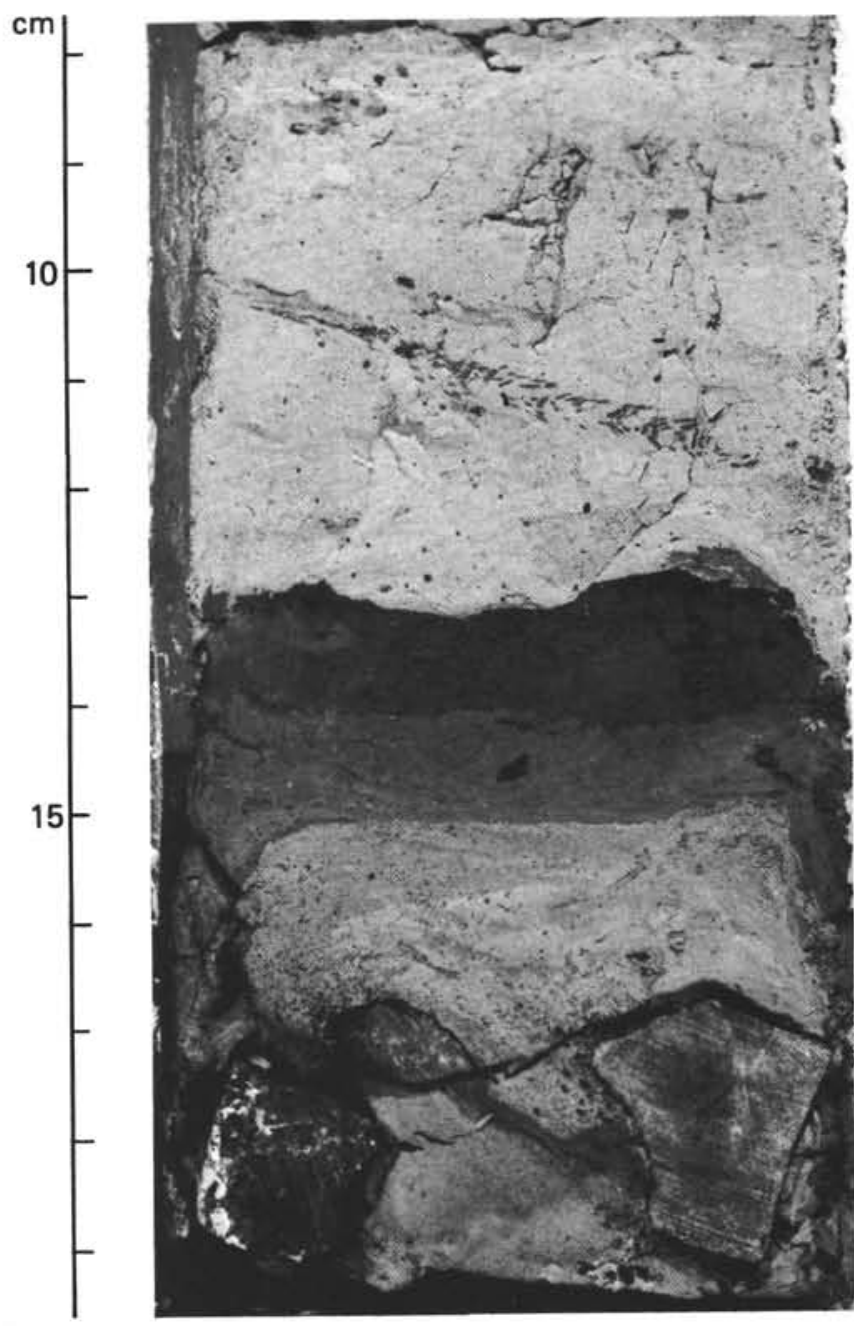

Figure 14. Angular fragments of silicified calcarenite in marly chalk (bottom), overlain by marlstone (dark) and burrowed chalk. 415-5, CC; lower Miocene.

$0.058 \mathrm{~kg} / \mathrm{cm}^{2}$. This compares favorably with Lee's (1973) results on claystone from Leg 19 at the same depth and with Trabant's (1978) results on claystones from Leg 41, also at similar depths.

\section{Thermal Conductivity}

Only one thermal conductivity measurement was successful: in a mudstone from 444 meters (415A-5-1, 98 $\mathrm{cm})$, the conductivity was $1.88 \mathrm{mcal} / \mathrm{cm}-\mathrm{s} .{ }^{\circ} \mathrm{C}$. The sample had a wet-bulk density of $1.73 \mathrm{~g} / \mathrm{cm}^{3}(57.9 \%$ porosity).

\section{Sound Velocity}

In general, sound velocities are higher parallel to the bedding than perpendicular to the bedding. In the Tertiary section, sound travels 0 to 15 per cent faster horizontally (typically $\sim 0-4 \%$ ). In the Cretaceous section, sound travels faster horizontally by 0 to 20 per cent ( $12 \%$ being typical). Acoustic anisotropy may be created by any combination of (1) alignment of longer or
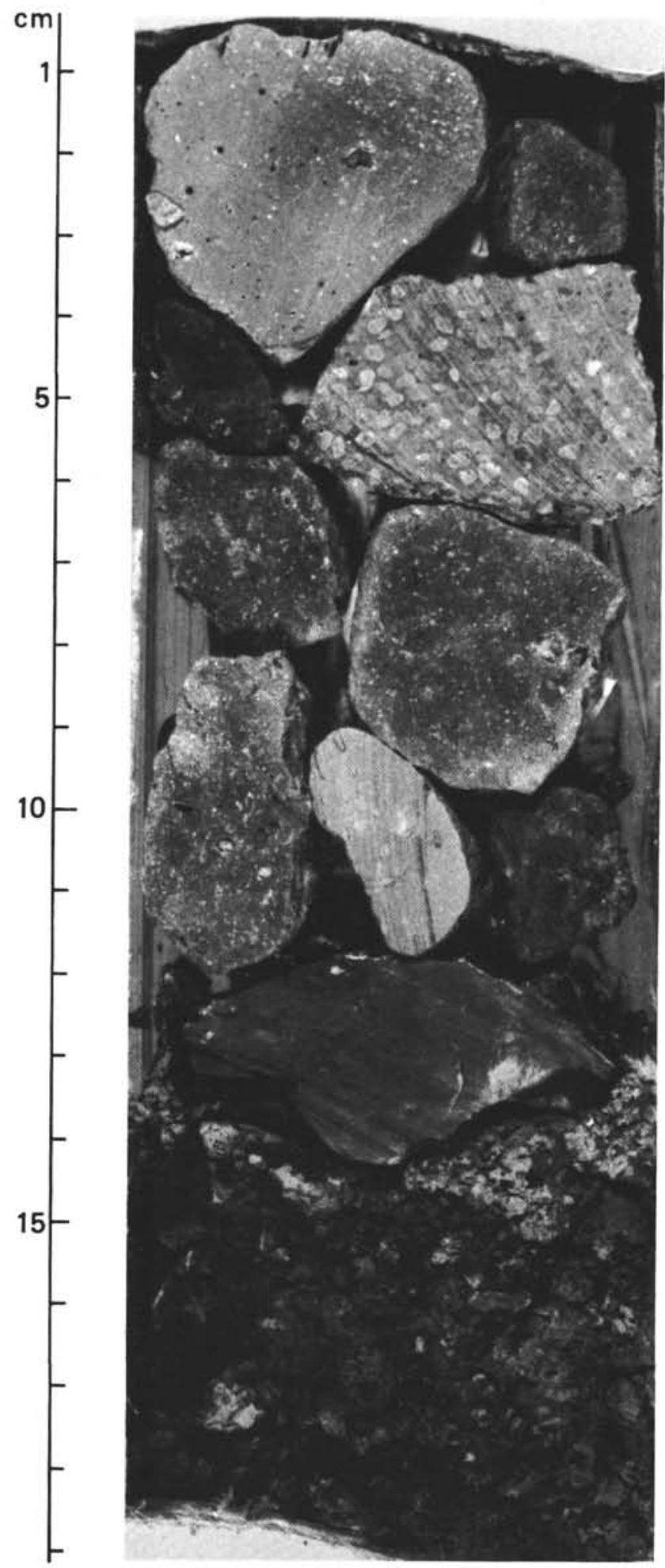

Figure 15. Pebbles of silica-cemented quartz sandstone and siltstone, and an angular piece of porcellanite (bottom clast). The lowest $5 \mathrm{~cm}$ in the core is an artificial drilling breccia. 415A-1,CC; lower Eocene.

platey minerals parallel to bedding (particularly clay minerals), creating a faster path because there are fewer gaps between minerals; (2) the presence of minerals which have different velocities in different crystallo- 


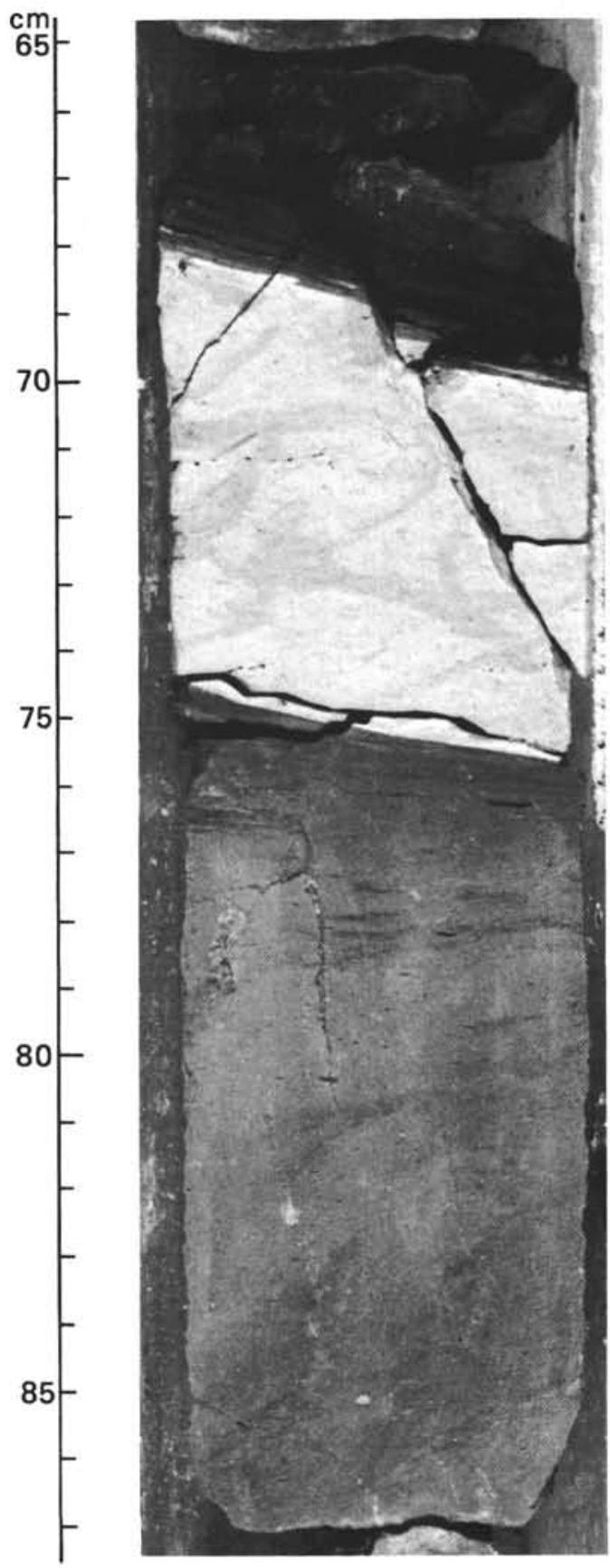

Figure 16. Nannofossil-chalk layer $(69-75 \mathrm{~cm})$ intercalated in light-olive-gray marlstone. The abundant and well-preserved calcareous fossils in the chalk suggest either accumulation well above the CCD or rapid redeposition from shallower water. Note also the change in dip of the inclined bedding, from about 15 degrees at the top of the chalk to horizontal in the underlying marlstone. The top of the white chalk layer corresponds to an unconformity truncating the upper part of the lower Paleocene. The placement of the core is different in this figure than in the core photographs at the end of this chapter, because of slippage of core material in the core tray. The depth shown in this figure corresponds to depths used by the shipboard paleontologists. $415 \mathrm{~A}-6-1,64-88 \mathrm{~cm}$; lower to upper Paleocene.

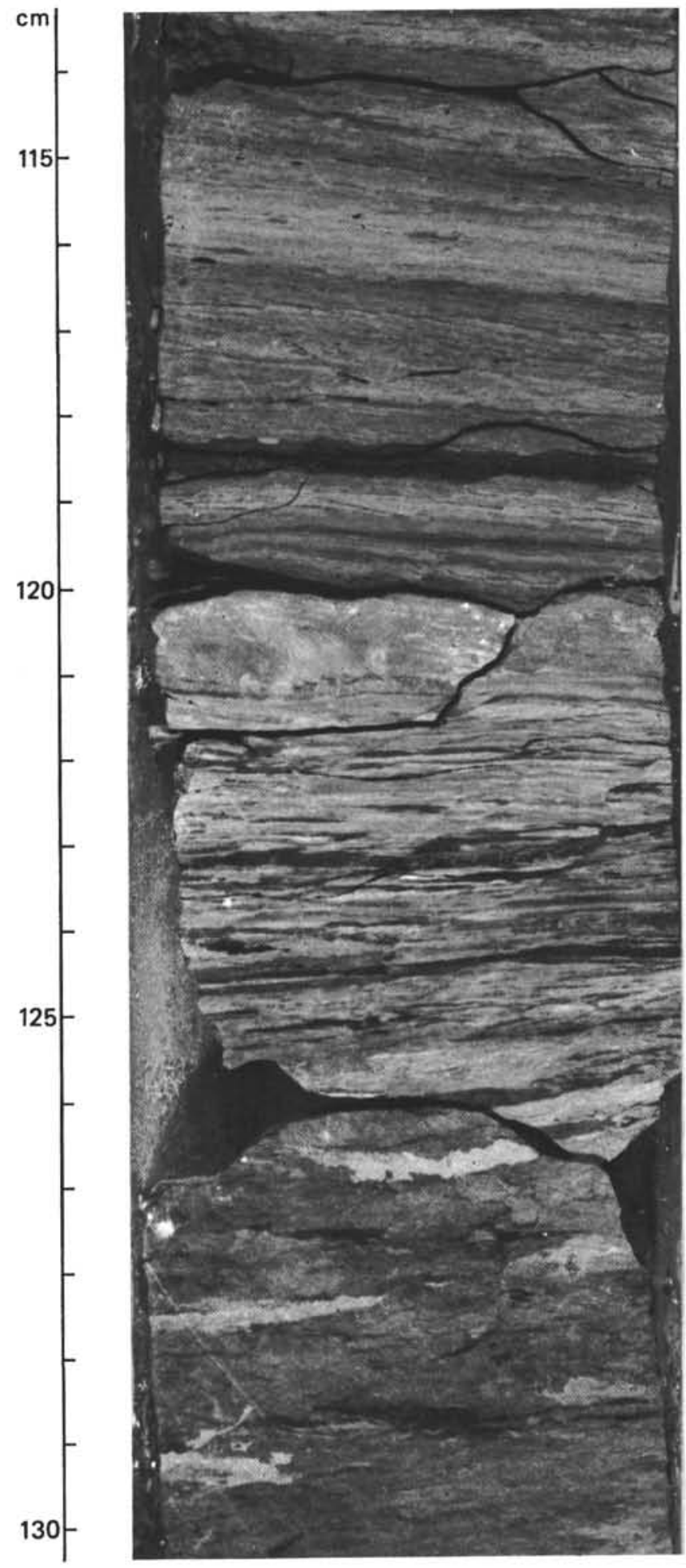

Figure 17. Thin, white, chalky laminae interlayered with light-olive-gray to green-gray marlstone. Some of the laminae are discontinuous and flaser-like. Note the low-angle normal faults cutting the laminae at $123 \mathrm{~cm} .415 A-6-2,114-131 \mathrm{~cm}$; lower Paleocene.

graphic orientations; (3) the presence of alternating high- and low-velocity laminae; and (4) foliation. Only the first factor is judged to be important at Site 415 .

The interval velocity calculated for the Tertiary section is $2.002 \mathrm{~km} / \mathrm{s}$ (or $1.82 \mathrm{~km} / \mathrm{s}$ if data from Cores $1 \mathrm{~A}$ 


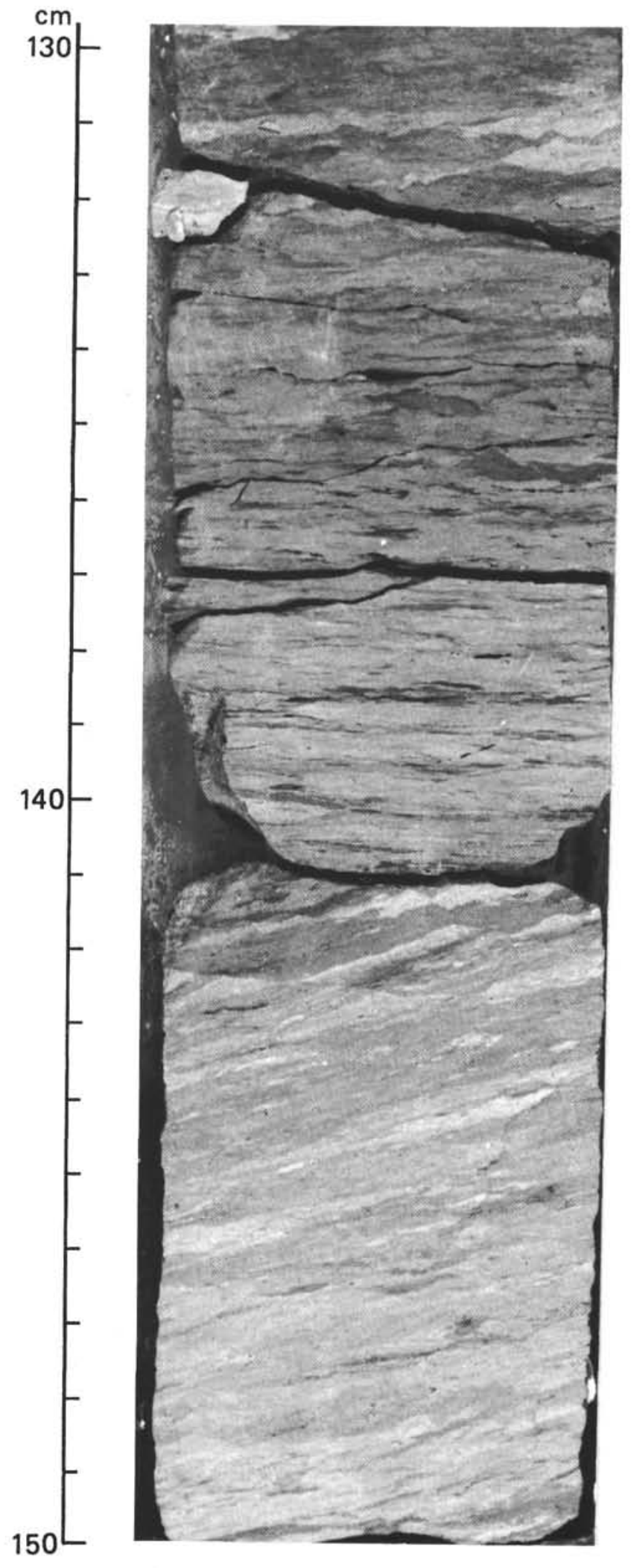

Figure 18. Greenish-gray, marly nannofossil chalk, with microfolds and low-angle microfaults that deform plastic sediments. 415A-6-2, 130-150 cm; lower Paleocene.

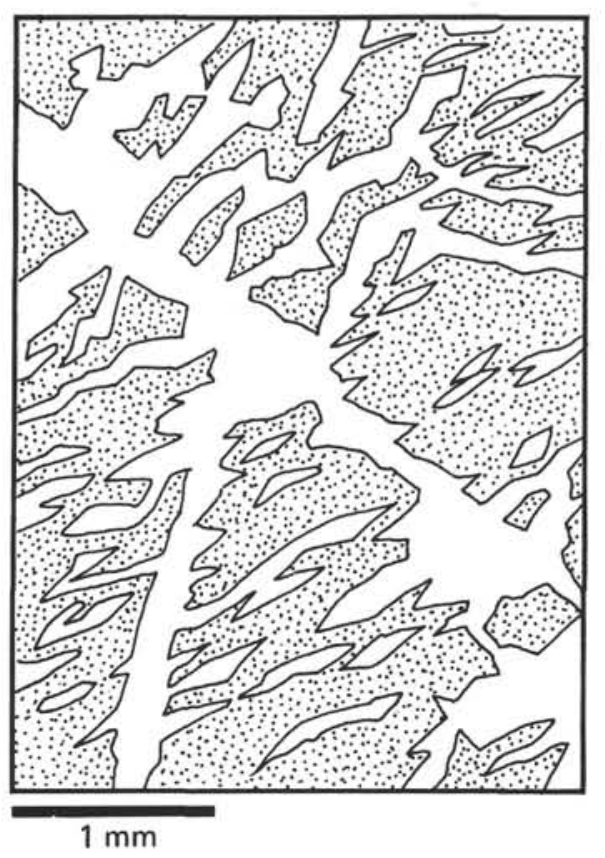

Figure 19. Neomorphic calcite spar in shale (stippled). Calcite occurs in lenses parallel to sedimentary lamination and along two fracture systems. 415A-11-2, 38-40 cm; middle Cenomanian.

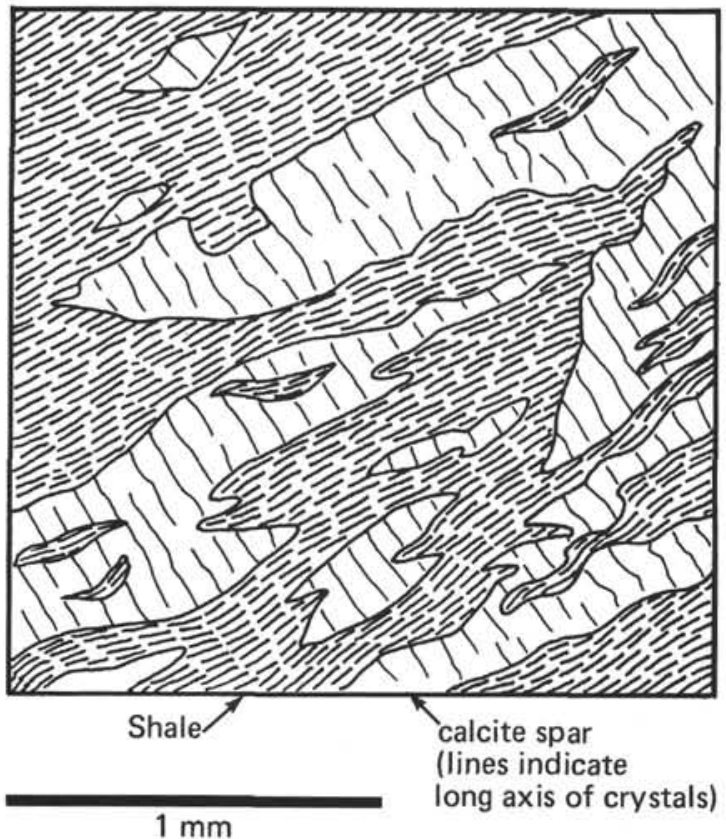

Figure 20. Lenses of neomorphic calcite spar with crystals oriented perpendicular to sedimentary lamination and elongation of lenses. 415-11-2, 38-40 cm; middle Cenomanian.

and 4A are not considered characteristic of the in situ geologic section), and for the Cretaceous section it is $2.08 \mathrm{~km} / \mathrm{s}$. These values are corrected for porosity rebound, salinity (data from Sites 370 and 415), in situ 


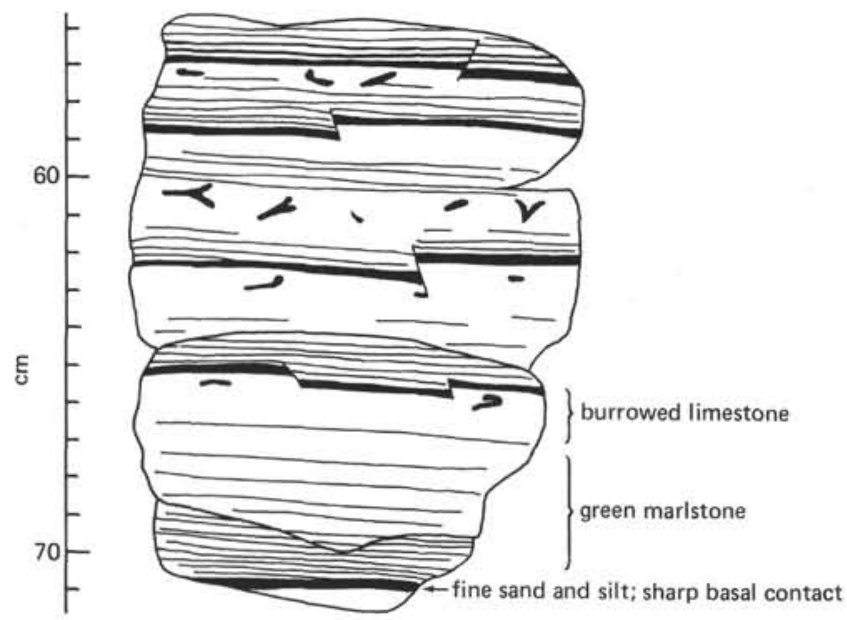

Figure 21. Graded sequences with sharp bases and gradational tops, interpreted as turbidites, overlain by layers showing low-angle cross-stratification. $415 \mathrm{~A}$ 10-1, 54-71 cm; middle Cenomanian.

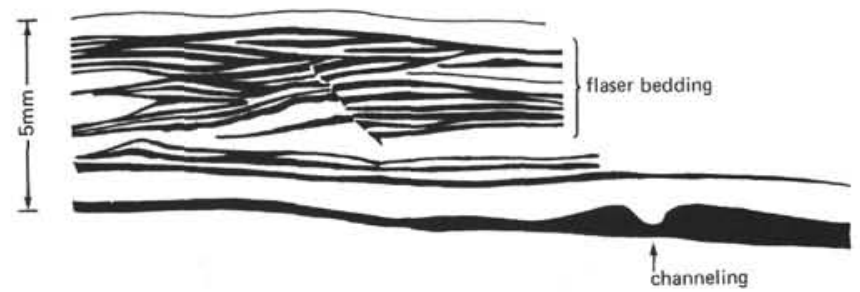

Figure 22. Lamination in marlstone. Low-angle crossstratification (flaser bedding) and channeling suggest weak bottom currents. The shear plane cutting diagonally across the specimen is probably caused by early diagenetic creep. 415A-14-1, 23-33 cm; upper Albian.

hydrostatic pressure, and temperature, as discussed in Boyce (1976); however, because there is no correction for grain-to-grain overburden pressure, these velocity values are minimal. Details of the calculations are in Boyce (this volume).

Several assumptions were made in these calculations. The temperature gradient is taken as $30^{\circ} \mathrm{C}$ per 1000 meters depth below the sea floor $\left(3.0^{\circ} \mathrm{C}\right)$, based on the temperature $\log$ at Site 416 . The interval velocity used for the Tertiary section, at laboratory pressure and temperature, is $1.930 \mathrm{~km} / \mathrm{s}$; this value assumes (1) a surface velocity of $1.51 \mathrm{~km} / \mathrm{s}$; (2) that samples in Core $1 \mathrm{~A}$ and 4A are representative of the in situ geologic section, and not just the most drill-resistant rocks surviving the coring operations; and (3) that Cores $415 \mathrm{~A}-4,415 \mathrm{~A}-5$, and $415 \mathrm{~A}-6$ can be treated as a single core in the averaging process. On the other hand, if one assumes that Cores $415 \mathrm{~A}-1$ and $415 \mathrm{~A}-4$ are not representative of the in situ geologic section, and therefore discards the data from these cores, then the calculated interval velocity is 1.72 $\mathrm{km} / \mathrm{s}$. A typical interstitial-water salinity of $47.6 \mathrm{per}$ mill (range of $35-60 \%$ ) was used in these calculations.

The Cretaceous section was assumed to be 90 per cent mudstone and 10 per cent limestone. At laboratory tem- peratures and pressures, an interval velocity of 1.86 $\mathrm{km} / \mathrm{s}$ is calculated for the mudstone, and $3.20 \mathrm{~km} / \mathrm{s}$ for the limestone. A typical interstitial-water salinity of 51 per mill was assumed (range $47-60 \%$ ).

The other laboratory physical-property data will not be discussed, because their variations are conveniently seen in the graphs and tables.

\section{Schlumberger Well Logs}

Schlumberger logging tools are described in Appendix 2. These logs were run in Hole 415: (1) the borehole compensated sonic (BHC) and gamma ray (GR); (2) the formation density compensation $\log$ (FDC) and compensated neutron log (CNL); (3) the dual induction Laterolog-8 (in fresh mud) and GR; and (4) gamma ray through pipe (see Figures 30 to 32). The GR detects natural gamma radiation and mainly responds to clayey (high-response) sediments; it is used on each logging run for correlations of the runs.

A caliper log was intended to accompany the sonic $\log$, but it would not pass through the pipe properly. Lacking a caliper, we may suspect enlarged hole conditions, because there is a relatively wide discrepancy between the deep induction log (ID) (assuming no invasion and that the true formation resistivity is significantly less or greater than the resistivity of the mud in the hole) and the medium induction $\log$ (IM). If the hole is of normal diameter, the ID and IM curves are close, but if the hole is too wide the IM will read a much higher resistivity than the ID, because the IM will be affected by the high resistivity of the fresh mud which was placed in the hole. This will be correct only where the true formation resistivity is lower than the mud resistivity, as in Hole 415. Hole conditions can also be estimated from the FDC Log by looking at the "delta density" plot, which is the correction applied to the FDC when the formation density is calculated; if a large $\left(-0.15 \mathrm{~g} / \mathrm{cm}^{3}\right)$ correction is applied, then the hole diameter may be enlarged.

The sonic $\log (\mathrm{BHC})$ is obviously important in interpreting the seismic-profile data, and it aids in locating acoustic reflectors. The BHC log plots integrated acoustic travel time versus depth, but because of a malfunction in the tool that caused high-velocity spikes, the log is inaccurate, and any integrated velocity derived from it will be too high. According to Lynch (1962), artificial, sharp deflections to the right (higher velocities) may be created by triggering due to "noise," and sharply lower artificial velocities may be caused by "cycle skipping." According to Schlumberger (1972), the BHC transmits a pulse which travels through the formation and is received by two receivers spaced $61 \mathrm{~cm}$ apart. The sound velocity is the difference between the arrival times divided by the distance between the receivers. "Cycle skipping" occurs when the outgoing pulse is strong enough to trigger the first receiver but not the second. "Instead the far receiver may be triggered by a different, later arrival in the sonic wave train, and the travel time measured on this pulse cycle will be too large... Such skipping is more likely to occur when the signal is strongly attenuated by unconsolidated formation..." 

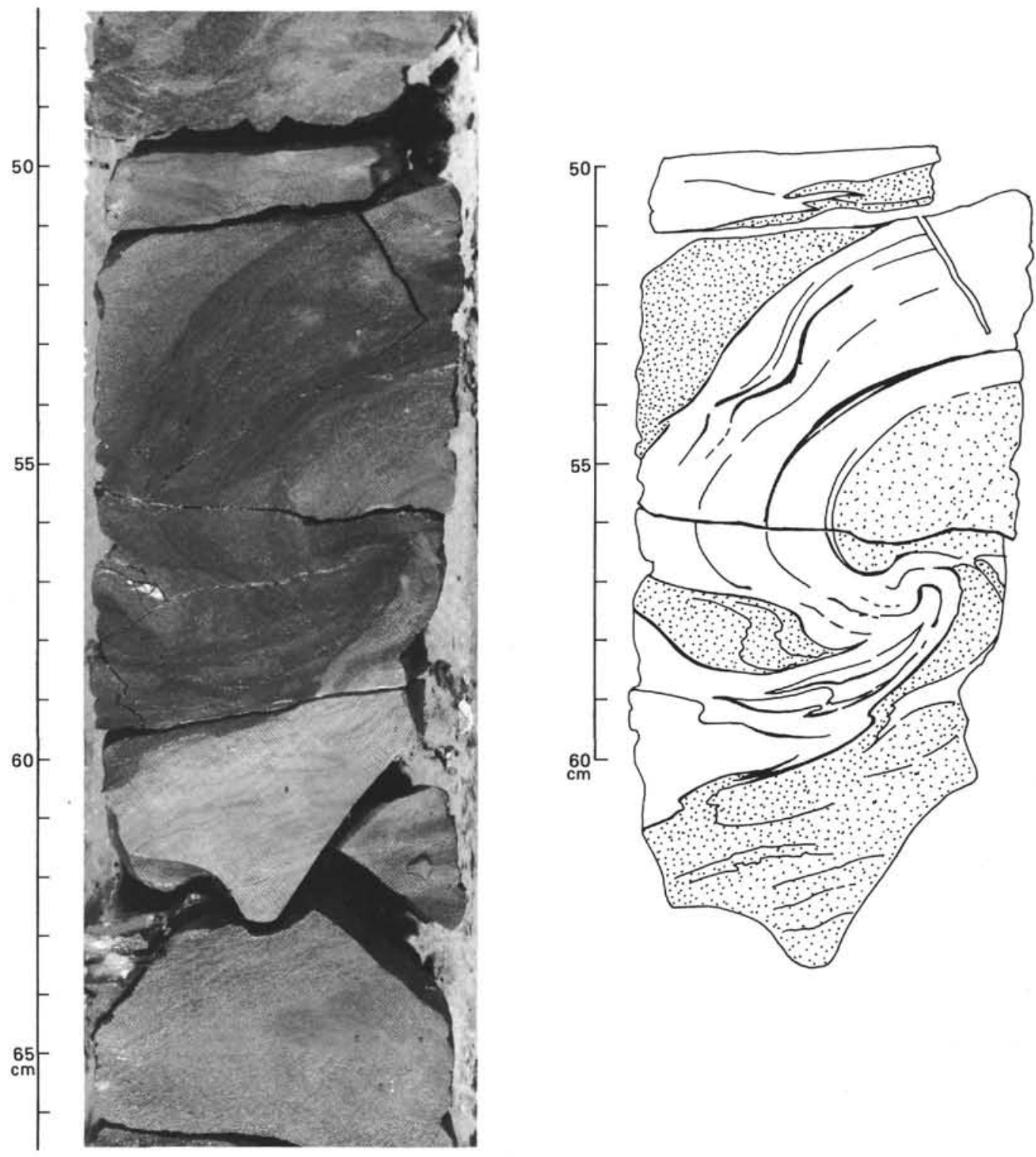

Figure 23. Slump fold in mudstone and marl (stippled). 415A-9-1, 50-60 cm; middle Cenomanian.

Because the compensated neutron log $(\mathrm{CNL})$ is designed primarily for low-porosity, hard formations, the high formation porosity in Hole 415 saturated the CNL (at $65 \%$ porosity). In part, the saturation may have been caused by an eccentering arm which could extend only $30 \mathrm{~cm}$ and which is located at the bottom of the 8.3-meter-long FDC-CNL tool combination. Since the $\mathrm{CNL}$ is at the top of the FDC-CNL tool, the CNL can be pulled away from the side of a vertical hole as the top of the tool is pulled upward and toward the center of the hole. Because the CNL may not have been against the side of the hole, it may have "seen" large artificial porosity and become saturated.

The wet-bulk density recorded on the FDC Log will be true density provided the formation is limestone saturated with fresh water, which is the lithology for which the FDC tool is empirically calibrated. For formations which have saline interstitial water or have solid minerals which do not have the attenuation coefficient or grain density of limestone, the true densities can still be calculated, as shown in Schlumberger (1972) and Tittman and Wahl (1965).

To use the electric logs properly, one should compare the porosity (assuming a grain density) derived from the FDC to the porosity calculated from the electric log [e.g., through use of the Archie (1942) equation]. Any large difference between these two calculated porosities may indicate (1) salinity or temperature anomalies; (2) a grain density significantly different from that used to calculate the porosity from the FDC log, which might identify a layer of high-density minerals; (3) the presence of minerals which are electrically conductive; or (4) the presence of oil or gas.

\section{Evaluation of Hole 415 Logging Data}

Since the caliper did not pass through the pipe in Hole 415 , the variations in diameter of the hole are not known.

To evaluate the degree to which the logged formations were soft and thus perhaps disturbed by the drill- 
TABLE 6

Concentrations of $\mathrm{CH}_{4}, \mathrm{CO}_{2}$, and $\mathrm{C}_{2}-\mathrm{C}_{5}$, Site 415

\begin{tabular}{|c|c|c|c|c|c|c|c|c|c|}
\hline \multirow[b]{2}{*}{ Core } & \multirow{2}{*}{$\begin{array}{l}\text { Sub-bottom } \\
\text { Depth } \\
\text { (m) }\end{array}$} & $\mathrm{CH}_{4}$ & $\mathrm{CO}_{2}$ & $\mathrm{C}_{2} \mathrm{H}_{6}$ & $\mathrm{C}_{3} \mathrm{H}_{8}$ & $i-\mathrm{C}_{4} \mathrm{H}_{10}$ & $n-\mathrm{C}_{4} \mathrm{H}_{10}$ & $i-\mathrm{C}_{5} \mathrm{H}_{12}$ & $n-\mathrm{C}_{5} \mathrm{H}_{12}$ \\
\hline & & \multicolumn{2}{|c|}{ (vol. \%) } & \multicolumn{6}{|c|}{ (ppm by vol.) } \\
\hline $415 \mathrm{~A}-3$ & $137.5-147$ & 0.03 & 0.16 & & & & & & \\
\hline 5 & $273.5-283$ & 0.3 & 0.08 & 2.9 & & & & & \\
\hline 5 & $443.0-452$ & 27.3 & 0.14 & 83.2 & & & & & \\
\hline 6 & $452.0-509.5$ & 20.2 & 0.25 & 54.8 & & & & & \\
\hline 7 & $509.5-519$ & 4.7 & 0.13 & 43.7 & 2.1 & & & & \\
\hline 8 & $519.0-585.5$ & 16.7 & 0.29 & 126.2 & 11.6 & 2.7 & 2.2 & 1.3 & 0.6 \\
\hline 9 & $642.0-752$ & 29.8 & 0.20 & 239 & 31 & 11.6 & 6.8 & 5.6 & 2.8 \\
\hline 10 & $709.0-718.5$ & 57.5 & 0.16 & 414.3 & 55.6 & 19.2 & 8.4 & 7.0 & 1.7 \\
\hline 11 & $794.0-804$ & 49.6 & 0.17 & 733.6 & 113.4 & 60 & 22.0 & 18.5 & 8.4 \\
\hline 12 & $880.0-889.5$ & 34.1 & 0.20 & 424.2 & 63 & 28.2 & 10.9 & 9.0 & 4.5 \\
\hline 13 & $956.0-965.5$ & 26.0 & 0.16 & 588 & 97.4 & 53.1 & 19.2 & 18.0 & 6.7 \\
\hline 14 & $1032.0-1041.5$ & 59.8 & 0.25 & 1222.3 & 142 & 70.4 & 24.3 & 20.7 & 7.8 \\
\hline
\end{tabular}

ing operations, the FDC log is examined, because it has a shallow depth of investigation. The data from the FDC and dual induction-Laterolog-8 were compared at two stratigraphic intervals (202.5 and $233 \mathrm{~m})$. At these intervals the resistivity values of the dual inductionLaterolog- 8 combination were used to calculate porosity, which then can be compared to the porosity derived from the FDC log, assuming a grain density (e.g., 2.7 $\mathrm{g} / \mathrm{cm}^{3}$ ). The resistivity data were solved for true formation resistivity, and the interstitial-water resistivity was calculated by assuming a bottom-water temperature of $3^{\circ} \mathrm{C}$ and a vertical temperature gradient of $30^{\circ} \mathrm{C} / \mathrm{km}$. The interstitial-water salinities were also measured $(39 \%$ ) ; therefore, the interstitial-water resistivity could be determined (Thomas et al., 1934). The ratio of the formation resistivity to the interstitial-water resistivity is called the formation factor $(F)$. The formation factor at the 202.5 meter depth was: $F=(1.37 \mathrm{ohm}-\mathrm{m}) /(0.244$ ohm-m) $=5.61 ;$ and at 233 meters, $F=(0.816$ ohm-m $) /(0.231 \mathrm{ohm}-\mathrm{m})=3.53$. From these formation factors, various theoretical porosities can be calculated. Using Archie's (1942) formula, $F=\phi^{-2}$, where $\phi$ is fractional porosity; substituting the two formation factors, 5.61 and 3.53 , the corresponding porosities are 43 and 54 per cent. If "Humble's" formula (Winsauer et al., 1952) is used, $F=0.62 \phi^{-2.15}$, and the resulting porosities are 37 and 45 per cent. Boyce's (1968) equation, $F=1.3 \phi^{-1.45}$, yields porosities of 37 and 50 per cent. In general, the Archie (1942) and Boyce (1968) equations compare well to the porosities of 40 and 51 per cent derived from the wet-bulk densities from the FDC $\log$ ( 2.04 and $1.84 \mathrm{~g} / \mathrm{cm}^{3}$; see Boyce, this volume). In summary, the FDC log appears to record true formation density.

If the widely spaced and sparse laboratory data are plotted for all the Cenozoic sedimentary rocks, the trend is toward slightly increasing density and velocity with depth. Superimposed on this trend, however, are irregular variations in the logging densities and velocities between 108 and 270 meters. The irregular variations in the density and sonic logs are confirmed by irregular fluctuations in the drill rate, and by the deepinvestigating dual induction log. The dual induction log investigates deeply enough (1.5 meters) to be unaffected by hole-diameter problems which may affect the shallowinvestigating sonic $(10 \mathrm{~cm})$ or density $(50 \mathrm{~cm})$ logs.

Direct comparison of the laboratory velocity and wet-bulk-density data with the Schlumberger logging data shows that they are not everywhere identical. On the other hand, considering the continuity of the logging and the small number and small size of laboratory samples, the log and laboratory data match fairly well. It also must be kept in mind that the coring and logging depths may not be correlated correctly in detail, and that the logging tools may move up and down as the ship heaves. In Core 415-3, laboratory densities and velocities match almost identically the density and velocity of the logs, but in Core 415-4 the direct comparisons are not as close. At the depth of Core $415-4$, the density logs show a range of 1.6 to $2.2 \mathrm{~g} / \mathrm{cm}^{3}$, and in Core $415-4$ laboratory densities are 1.7 to $1.95 \mathrm{~g} / \mathrm{cm}^{3}$. The velocities shown on the logs are 1.6 to $2.1 \mathrm{~km} / \mathrm{s}$, while the laboratory velocities are ábout 1.8 to $1.9 \mathrm{~km} / \mathrm{s}$.

To carry still further the comparisons between the logging data and the laboratory data, cross plots (see Boyce, this volume) of velocity versus density for the cores and the logs indicate that the velocity from the Schlumberger logs is reasonable. In fact, the cores show lower densities (equivalent to about 5 porosity units), than the in situ logs, as predicted by Hamilton's (1959, 1964,1965 , 1976) consolidation-rebound curves. Hamilton's data show that a rebound of about 5 per cent in porosity can be expected from uncemented (30-60\% porosity) sediments as the overburden pressure is released. Further testing at other sites is needed to be certain that the velocity logs are not slightly biased toward low values because of the very shallow depth of investigation of the $\mathrm{BHC} \log$.

\section{Preliminary Interpretation of Hole 415 Logs}

Characteristic stratigraphic intervals which can be established from the logging combination of gamma ray, sonic, density, and electrical-resistivity logs are (1) 108 meters (beginning of the log) to 170 meters, (2) 170 meters to 185 meters, (3) 185 meters to 199 meters, (4) 199 meters to 214 meters, (5) 214 meters to 226 meters, (6) 226 meters to 238 meters, and (7) 238 meters to 275 meters (end of logging data). The resistivity log con- 


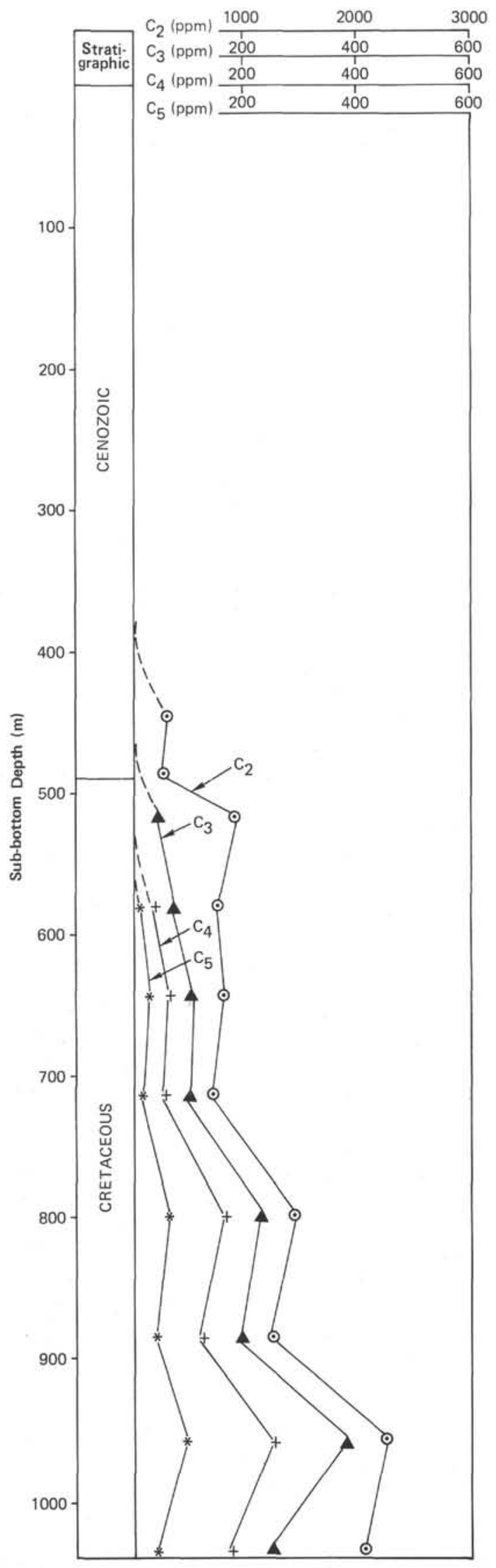

Figure 24. Variations in concentrations of $C_{2}-C_{5}$ hydrocarbons in Hole 415A. firms that all density changes are primarily related to porosity changes.

From 108 meters to 170 meters, the GR slightly and irregularly increased with depth, and the lithology observed in Core 415-3 (alternating marls and chalks) probably extends over this entire interval. Velocities are about $1.64 \mathrm{~km} / \mathrm{s}$ (range $1.52-1.78 \mathrm{~km} / \mathrm{s}$ ), and density irregularly increased from 1.8 to $1.9 \mathrm{~g} / \mathrm{cm}^{3}(54-48 \%$ porosity). The density has a range of 1.7 to $1.95 \mathrm{~g} / \mathrm{cm}^{3}$ (60-45\% porosity).

From 170 meters to 185 meters, the GR irregularly decreases very slightly, suggesting an increase in the proportion of chalk or of sands and silts, as at Site 370 . Velocity irregularly increases from 1.64 to $1.97 \mathrm{~km} / \mathrm{s}$, and the density irregularly increases from 1.9 to 2.1 $\mathrm{g} / \mathrm{cm}^{3}$ (46-36\% porosity).

From 185 meters to 199 meters, the GR has a slight irregular increase in intensity, which suggests an increasing proportion of marl. Velocity has an irregular (2.2$1.53 \mathrm{~km} / \mathrm{s}$ ) decrease from 2.0 to $1.6 \mathrm{~km} / \mathrm{s}$. This corresponds to a wet-bulk density decrease of 2.1 to 1.95 $\mathrm{g} / \mathrm{cm}^{3}$ (36-45\% porosity).

From 199 meters to 214 meters there are abrupt fluctuations between high and low GR intensities, which suggests alternating marls and chalks, with corresponding velocity and wet-bulk-density variations. The chalk has the higher densities and velocities. Velocities alternate abruptly (reflectors?) within a range of 1.6 to 2.2 $\mathrm{km} / \mathrm{s}$ (respective densities $1.7-2.1 \mathrm{~g} / \mathrm{cm}^{3} ; 60-36 \%$ porosity).

From 214 meters to 226 meters, the GR varies irregularly but does not change with increasing depth. It possibly suggests alternating chalks and clayey chalk. Velocities are about $1.65 \mathrm{~km} / \mathrm{s}(1.56-1.76 \mathrm{~km} / \mathrm{s}$ range). Density decreases slightly from 1.85 to $1.7 \mathrm{~g} / \mathrm{cm}^{3}$ (60-50\% porosity).

From 226 meters to 238 meters, the GR has a very high count; therefore, the lithology is probably marl. The GR change at 226 meters is very abrupt from a low count to a high count. Velocities are about $1.64 \mathrm{~km} / \mathrm{s}$ and slightly decreasing, with a variation between 1.66 and $1.58 \mathrm{~km} / \mathrm{s}$. Density is about $1.8 \mathrm{~g} / \mathrm{cm}^{3}(49 \%$ porosity) and slightly decreases; it varies from 1.75 to 1.97 $\mathrm{g} / \mathrm{cm}^{3}$.

From 238 meters to 275 meters (end of logging data), the GR varies irregularly, suggesting that the lithologies may be alternating chalks and marls. The GR very abruptly decreases at 238 meters. The velocity increases from 1.64 to $1.9 \mathrm{~km} / \mathrm{s}$, but the sonic log is of very poor quality at this depth. Density increases from 1.8 to 1.98 $\mathrm{g} / \mathrm{cm}^{3}$ (54-43\% porosity).

\section{Gamma Ray Log Through the Pipe, Hole 415A}

At Hole 415A, the GR was used through the pipe, because hole conditions were deteriorating in the lower 500 meters. Although 300 meters of the hole was still open and might have been fully logged, it was decided that the same section could be logged later in the Site 370 area.

The GR log at Hole 415A was taken through the pipe and recorded graphically at vertical scales of 1:200 and 
TABLE 7

Carbon and Nitrogen Contents and Pyrolysis Data, Site 415

\begin{tabular}{|c|c|c|c|c|c|c|c|}
\hline \multirow[b]{2}{*}{$\begin{array}{c}\text { Sample } \\
\text { (interval in cm) }\end{array}$} & \multirow{2}{*}{$\begin{array}{l}\text { Sub-bottom } \\
\text { Depth } \\
\text { (m) }\end{array}$} & \multirow[b]{2}{*}{$\mathrm{C}_{\text {org }}$} & \multirow[b]{2}{*}{$\mathrm{CO}_{3}$} & \multirow[b]{2}{*}{$\mathrm{N}_{2}$} & \multicolumn{3}{|c|}{ Pyrolysis Data } \\
\hline & & & & & $s_{1}+s_{2}$ & $\begin{array}{c}\mathrm{S}_{1} \\
\left(\mathrm{~S}_{1}+\mathrm{S}_{2}\right)\end{array}$ & $\begin{array}{l}T_{\mathrm{M}} \\
\left({ }^{\circ} \mathrm{C}\right)\end{array}$ \\
\hline $415-1-5,33-34$ & 7.8 & 0.37 & 68.0 & 0.02 & 0.19 & 0.32 & - \\
\hline $2-1,53-54$ & 74.5 & 0.27 & 40.5 & 0.02 & 0.22 & 0.27 & - \\
\hline $3-2,32-33$ & 140.8 & - & - & - & 0.07 & 0.07 & - \\
\hline $5 \cdot 1,13-15$ & 273.6 & - & - & - & 0.39 & 0.08 & 404 \\
\hline $5, \mathrm{CC}$ & 283.0 & 0.28 & 58.5 & 0.01 & 0.14 & 0.21 & - \\
\hline $415 A-5-1,26-30$ & 443.2 & 2.29 & trace & 0.14 & 8.09 & 0.006 & 414 \\
\hline $5, \mathrm{CC}$ & 444.5 & 0.47 & 1.0 & 0.08 & 0.31 & 0.011 & 429 \\
\hline $7, \mathrm{CC}$ & 510.1 & 0.32 & 1.0 & 0.06 & 2.08 & 0.012 & 416 \\
\hline $8 \cdot 2,42-43$ & 577.9 & 1.27 & 14.5 & 0.10 & 1.47 & 0.013 & 428 \\
\hline $8, \mathrm{CC}$ & 579 & 1.08 & 27.5 & 0.09 & 1.01 & 0.02 & 426 \\
\hline $9-1,68-70$ & 643.1 & 1.25 & 17.0 & 0.10 & 1.07 & 0.009 & 425 \\
\hline $10-2,39-40$ & 710.8 & 0.42 & 19.0 & 0.05 & 0.89 & 0.011 & 425 \\
\hline $11-2,11-12$ & 796.1 & 0.62 & 13.5 & 0.06 & 1.41 & 0.028 & 425 \\
\hline $12-1,28-30$ & 880.2 & 0.76 & 15.0 & 0.06 & 0.52 & 0.11 & 423 \\
\hline $13-2,42-44$ & 957.9 & 0.87 & 10.5 & 0.08 & 0.61 & 0.02 & 423 \\
\hline $13, \mathrm{CC}$ & 958.6 & - & - & - & 0.42 & 0.14 & 423 \\
\hline $14-1,43-45$ & 1032.4 & 0.72 & 17 & 0.070 & 0.84 & 0.049 & 425 \\
\hline $14, \mathrm{CC}$ & 1034.2 & - & - & - & 0.72 & 0.026 & 410 \\
\hline
\end{tabular}

1:1000, and at an expanded API scale. The log was run with a 3-second time constant in order to improve the statistical variation and resolution. In the upper parts of the hole, the GR was logged through the combined thickness of the drill pipe, the 40.6- $\mathrm{cm}$ (16-inch) casing, and the $29.8-\mathrm{cm}\left(11^{3 / 4}\right.$-inch) casing; the lower ends (the shoe) of these cased intervals are marked on the Schlumberger field prints. Of course, the GR response is attenuated because of the shielding provided by both the pipe and casing. In the lower part of the hole, the GR did not scan through the $17.8-\mathrm{cm}$ (7-inch) drill pipe, rather through the thicker drill collars and bumper subs, which have varying diameters. These extra shields also cause anomalously low gamma counts. When studying the GR data taken through the $17.8-\mathrm{cm}$ (7-inch) drill pipe, it is useful to keep in mind that the pipe joints at 9.5-meter intervals cause low gamma counts (inverse spikes).

In principle, if the GR were calibrated with the cores of known lithology, the log might be used to give some indication of the lithology between cores.

\section{Interpretation of the GR Log at Hole 415A}

In general, this log can be segregated into at least six intervals, three of which are artifacts of the casing, drill collars, and bumper subs:

1. From 0 to 73 meters, the GR is so heavily shielded by pipe and the two sets of casing that the data are probably useless.
2. From 73 to 333 meters, the GR is shielded by the pipe and the $29.8-\mathrm{cm}$ casing. The GR is very attenuated, but when it is compared to the GR recorded in the open bore hole of Hole 415, some very subtle correlations can be seen, although the data from Hole $415 \mathrm{~A}$ are probably too degraded to be used with much confidence. At 313 meters, the GR begins to increase gently, suggesting the top of the unit shown better from 333 to 383 meters.

3. From 333 to 383 meters, the GR shows a large, irregular increase interpreted as a decrease in clay content of the siltstone and sandstone. Core 415A-1, recovered in this interval, contained siltstone, sandstone, and porcellanite, but these rocks may not be characteristic of the geologic section. They may be only hard rocks that are most easily recovered with our coring techniques.

4. From 383 meters to 489 meters, the GR irregularly increases in intensity and probably represents chalk which gradually and irregularly changes to a marl or shale at 489 meters.

5. From 489 meters to 493 meters, the GR shows a very high response, which could represent an unconformity or clay layer deposited very slowly; where sediments accumulate slowly there may be increased concentrations of radioactive minerals. Although this GR peak may not represent the exact level of the Cretaceous/Tertiary boundary, the general character of the GR logs below this horizon is different from that above. Thus, this horizon, if not the Cretaceous/Tertiary contact, is an important lithologic boundary.

6. From 493 meters to 1008 meters (end of log), the GR $\log$ consists of alternating high and low gamma counts, which probably represent alternating mudstone, marl, and limestone. Below 583 meters, part of the log appears to repeat itself several times, in the same interval where the sedimentologists have identified faulted zones in the cores.

\section{BIOSTRATIGRAPHY}

\section{Biostratigraphic Summary}

The 1079-meter-thick sedimentary section penetrated at Site 415 represents a sequence from Quaternary to late Albian, with a remarkably thick $(>300 \mathrm{~m})$ middleCenomanian interval (Figure 34 ). There are two substantial hiatuses of about 25 to 30 m.y., spanning the
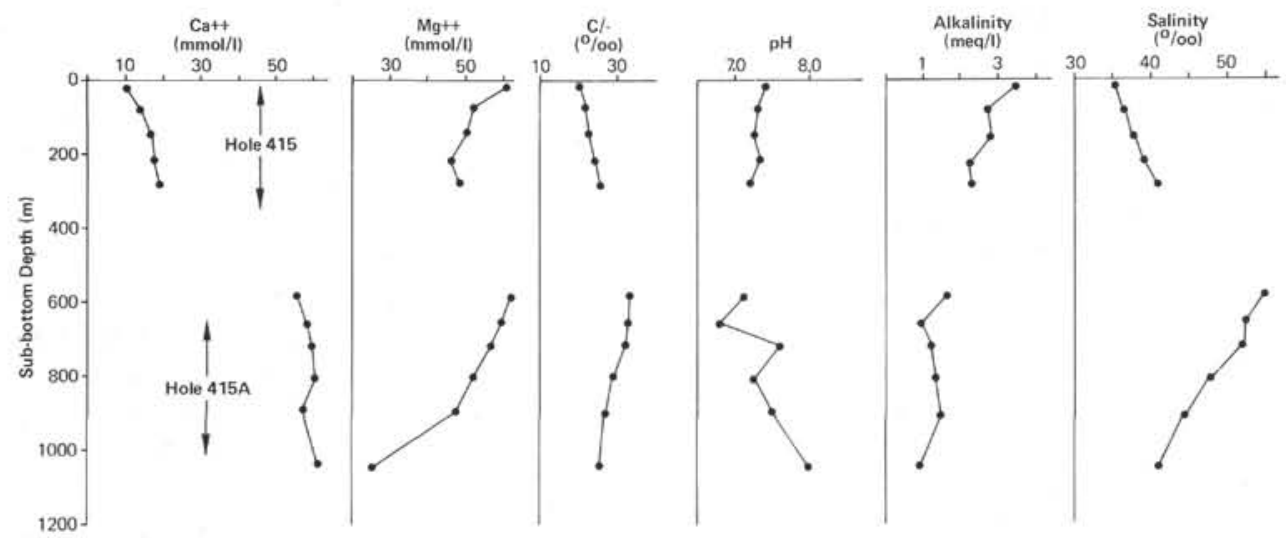

Figure 25. Chemical composition of the pore waters, Holes 415 and $415 \mathrm{~A}$. 
TABLE 8

Physical Properties of Sediments, Site 415

\begin{tabular}{|c|c|c|c|c|c|c|c|c|c|c|c|c|}
\hline \multirow[b]{3}{*}{$\begin{array}{c}\text { Sample } \\
\text { (interval in cm) }\end{array}$} & \multirow{3}{*}{$\begin{array}{l}\text { Sub-bottom } \\
\text { Depth } \\
\text { (m) }\end{array}$} & \multicolumn{5}{|c|}{ Compressional-Sound Velocity } & \multirow{2}{*}{\multicolumn{2}{|c|}{$\begin{array}{c}\text { Grape "Special" } \\
\text { Wet-Bulk Densitya } \\
\text { (2-min count) } \\
\left(\mathrm{g} / \mathrm{cm}^{3}\right)\end{array}$}} & \multirow{3}{*}{$\begin{array}{c}\text { Wet-Water } \\
\text { Content } \\
\text { (salt corr.) } \\
(\%)\end{array}$} & \multirow[b]{3}{*}{$\begin{array}{l}\text { Porosityb } \\
\text { (\%) }\end{array}$} & \multirow{3}{*}{$\begin{array}{l}\text { Acoustic } \\
\text { Impedance } \\
\frac{\mathrm{g} \times 10^{5}}{\mathrm{~cm}^{2}-\mathrm{s}}\end{array}$} & \multirow[b]{3}{*}{ Lithology } \\
\hline & & \multirow{2}{*}{$\begin{array}{c}\| \\
\text { Beds } \\
(\mathrm{km} / \mathrm{s})\end{array}$} & \multirow{2}{*}{$\begin{array}{c}1 \\
\text { Beds } \\
(\mathrm{km} / \mathrm{s})\end{array}$} & \multicolumn{2}{|c|}{ Anisotropy } & \multirow[b]{2}{*}{$\begin{array}{l}\text { Temp. } \\
\left({ }^{\circ} \mathrm{C}\right)\end{array}$} & & & & & & \\
\hline & & & & $\begin{array}{c}1-1 \\
(\mathrm{~km} / \mathrm{s})\end{array}$ & $\begin{array}{c}(1-1) / 1 \\
(\%)\end{array}$ & & $\begin{array}{c}\| \prime \\
\text { Beds }\end{array}$ & $\begin{array}{c}1 \\
\text { Beds }\end{array}$ & & & & \\
\hline $415-2-1,131-133$ & 75.31 & 1.588 & 1.588 & 0.000 & 0.00 & 28 & - & 1.828 & 35.60 & 63.06 & 2.903 & Foraminifer-nannofossil marl \\
\hline $2-1,64-70$ & & - & - & - & - & - & - & - & 35.92 & - & - & Foraminifer-nannofossil marl \\
\hline $2, \mathrm{CC}$ & & & - & - & - & - & - & - & 28.41 & - & - & (Interstitial water) \\
\hline $3-3,15-17$ & 140.65 & 1.733 & 1.729 & 0.004 & 0.23 & 28 & - & 1.815 & 33.37 & 58.69 & 3.138 & Foraminifer-nannofossil marl \\
\hline $4-1,140-142$ & 208.40 & 1.876 & 1.802 & 0.074 & 4.11 & 26 & - & 1.718 & 36.76 & 61.20 & 3.096 & Foraminifer-nannofossil chalk \\
\hline $4-3,128-130$ & 211.28 & 1.917 & 1.814 & 0.103 & 5.68 & 26 & - & 1.954 & 24.99 & 47.32 & 3.545 & Nannofossil chalk \\
\hline $5-1,10-12$ & 273.60 & 1.761 & 1.721 & 0.040 & 2.32 & 25 & - & 1.816 & - & - & 3.125 & Sandy nannofossil chalk \\
\hline $5-3,144-146$ & 277.94 & 1.876 & 1.852 & 0.024 & 1.30 & 26 & - & 1.885 & - & - & 3.491 & Nannofossil chalk (silica-rich) \\
\hline $5-5,140-142$ & 280.90 & 2.055 & 2.001 & 0.054 & 2.70 & 26 & - & 1.893 & - & - & 3.788 & Nannofossil marl (silica-rich) \\
\hline 415A-1,CC piece \#1 & 349.1 & - & 2.652 & - & - & 25 & - & - & - & - & - & Siltstone \\
\hline piece $\# 2$ & & & 3.958 & 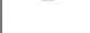 & & 25 & & & & & & Silty Sandstone \\
\hline piece $\# 3$ & & & 2.474 & & & 25 & & & & & & Siltstone \\
\hline piece $\# 4$ & & & 2.388 & & & 25 & & & & & & Siltstone \\
\hline piece $\# 5$ & & & 2.358 & & & 25 & & & & & & Siltstone \\
\hline piece \#6 & & & 3.953 & & & 25 & & & & & & Sandstone \\
\hline piece $\# 7$ & & & 3.972 & & & 25 & & & & & & Porcellanite \\
\hline $4, \mathrm{CC}$ & - & - & 2.670 & - & - & 26 & - & - & - & - & - & Nannofossil marl (silica-rich) \\
\hline $5 \cdot 1,18-20$ & 443.19 & 2.016 & 1.760 & 0.256 & 14.55 & 26 & - & 1.887 & 27.12 & 49.59 & 3.321 & Mudstone \\
\hline $5-1,48-50$ & 443.48 & 2.483 & 2.233 & 0.250 & 11.20 & 26 & 1.841 & - & 25.20 & 44.95 & 4.111 & Mudstone \\
\hline $6-1,42-44$ & 452.92 & 1.753 & 1.761 & -0.008 & -0.45 & 25 & - & 1.699 & 35.34 & 58.18 & 2.992 & Nannofossil marl \\
\hline $6-1,149-151$ & 455.49 & 2.124 & 1.972 & 0.152 & 7.71 & 25 & - & 2.081 & 19.39 & 39.10 & 4.104 & Nannofossil chalk \\
\hline $8-1,11-13$ & 576.11 & 1.715 & 1.511 & 0.204 & 13.50 & 26 & - & 1.802 & 28.65 & 50.03 & 2.723 & Mudstone \\
\hline $8-1,140-150$ & 577.45 & - & - & - & - & - & - & - & 27.10 & - & - & (Interstitial water) \\
\hline $8-2,92-94$ & 578.42 & 1.810 & 1.671 & 0.139 & 8.32 & 27 & - & 1.861 & 26.46 & 47.72 & 3.110 & Mudstone \\
\hline $8, C^{14-16}$ & 578.85 & 3.219 & 3.263 & -.044 & -1.35 & 28 & - & 2.522 & 6.45 & 15.76 & 8.229 & Limestone \\
\hline $9-1,128-129$ & 643.78 & - & - & - & - & - & - & - & 21.67 & - & - & \\
\hline $9-2,136-138$ & 645.39 & - & - & - & - & - & - & 2.022 & 24.41 & 47.83 & - & Marlstone \\
\hline $9-4,140-150$ & 648.45 & - & - & - & - & - & - & 2.022 & 21.20 & - & - & Marlstone \\
\hline $9, \mathrm{CC} 10-12$ & 649.37 & 2.613 & 2.884 & -0.271 & -9.40 & 28 & - & 2.454 & 8.23 & 19.57 & 7.077 & Limestone \\
\hline $10-1,18-20$ & 709.18 & 3.119 & 2.564 & 0.555 & 21.65 & 25 & - & 2.456 & 10.82 & 25.75 & 6.297 & Limestone \\
\hline $10-1,140-150$ & 710.45 & - & - & - & - & - & - & - & 19.07 & - & - & (Interstitial water) \\
\hline $11-1,140-150$ & 795.95 & & & & & & - & - & 18.66 & - & - & (Interstitial water) \\
\hline $11-2,39-41$ & 796.40 & & & & & & - & 2.440 & 7.02 & 16.60 & - & Limestone \\
\hline $11-2,66-68$ & 796.66 & 2.221 & 1.826 & 0.395 & 21.63 & 25 & - & 2.169 & 16.06 & 33.75 & 3.961 & Shale \\
\hline $12-1,140-150$ & 881.45 & - & - & - & - & - & - & - & 19.48 & - & - & (Interstitial water) \\
\hline $13-1,138-140$ & 957.39 & - & - & - & - & - & - & 2.292 & 12.33 & 27.38 & - & Shale \\
\hline $14-1,16-17$ & 1032.16 & 2.558 & 2.121 & 0.437 & 20.60 & 26 & - & 2.284 & 13.09 & 28.97 & 4.844 & Claystone \\
\hline $14-1,140-150$ & 1033.45 & - & - & - & - & - & - & - & 13.04 & - & - & (Interstitial water) \\
\hline $14, \mathrm{CC} 14-16$ & 1034.10 & 4.314 & 4.104 & 0.210 & 5.12 & 26 & - & 2.669 & 5.01 & 12.96 & 10.954 & Limestone \\
\hline
\end{tabular}

${ }^{a}$ The calculation used the following parameters: $\rho_{\mathrm{g}}, \rho_{\mathrm{gc}}=2.7 \mathrm{~g} / \mathrm{cm}^{3} ; \rho_{\mathrm{f}}=1.025 \mathrm{~g} / \mathrm{cm}^{3} ; \rho_{\mathrm{fc}}=1.128 \mathrm{~g} / \mathrm{cm}^{3} ; \mu=0.1028 \mathrm{~cm} 2 / \mathrm{g}$.

${ }^{\mathrm{P}}$ Porosity $=[($ salt-corrected wet-water content $) /($ wet-bulk density $)] /\left(\right.$ interstitial-water density); assumed salinity $=45 \%$; interstitial-water density $=1.032 \mathrm{~g} / \mathrm{cm}{ }^{3}$.

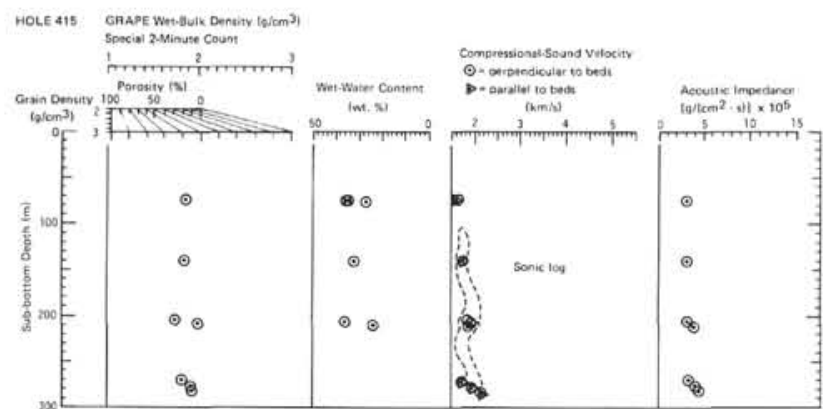

Figure 26. Physical properties and logging data versus depth, Hole 415.

earliest Miocene through the middle Eocene and most of the Late Cretaceous, respectively; there is also a minor hiatus of approximately $3 \mathrm{~m} . \mathrm{y}$. near the boundary of the late and early Paleocene.

A summary of the various fossil-group zonations plotted against sub-bottom depths is represented in the graphic hole summary (Figure 9). There is good agreement among the various fossil groups for age assignment of recovered sediments. Spot coring with broad uncored intervals and poor recovery, however, preclude precise positioning of epoch boundaries. Several of these were placed within uncored intervals on the basis of sedimentation rates or lithologic changes reflected on the gamma-ray log. (See Figure 33 and discussion on sedimentation rates.)

From top to bottom, the section consists of:

1. One hundred and thirty meters of upper-Neogene (upper-Miocene to Quaternary) foraminifer-nannofossil marl to nannofossil ooze (Cores 415-1 and 2; 415B-1 and 2), which contains abundant, well-preserved calcareous nannoplankton and abundant planktonic foraminifers, well preserved in the Pleistocene and Pliocene and less well preserved in the upper Miocene. Radiolarians are rare. They are poorly preserved and fragmented in the Plio-Pleistocene and moderately well preserved in the upper Miocene.

2. One hundred and eighty-three meters (130-313 m) of lower- and middle-Miocene alternating nannofossil marl, nannofossil ooze, and siliceous-debris-bearing marl (Cores 415-3 through 415-5) which contain common to abundant, poorly to moderately well preserved calcareous plankton and rare to common, moderately well preserved radiolarians.

3. An unconformity around 313 meters which reflects a lacuna encompassing probably the lower lower 


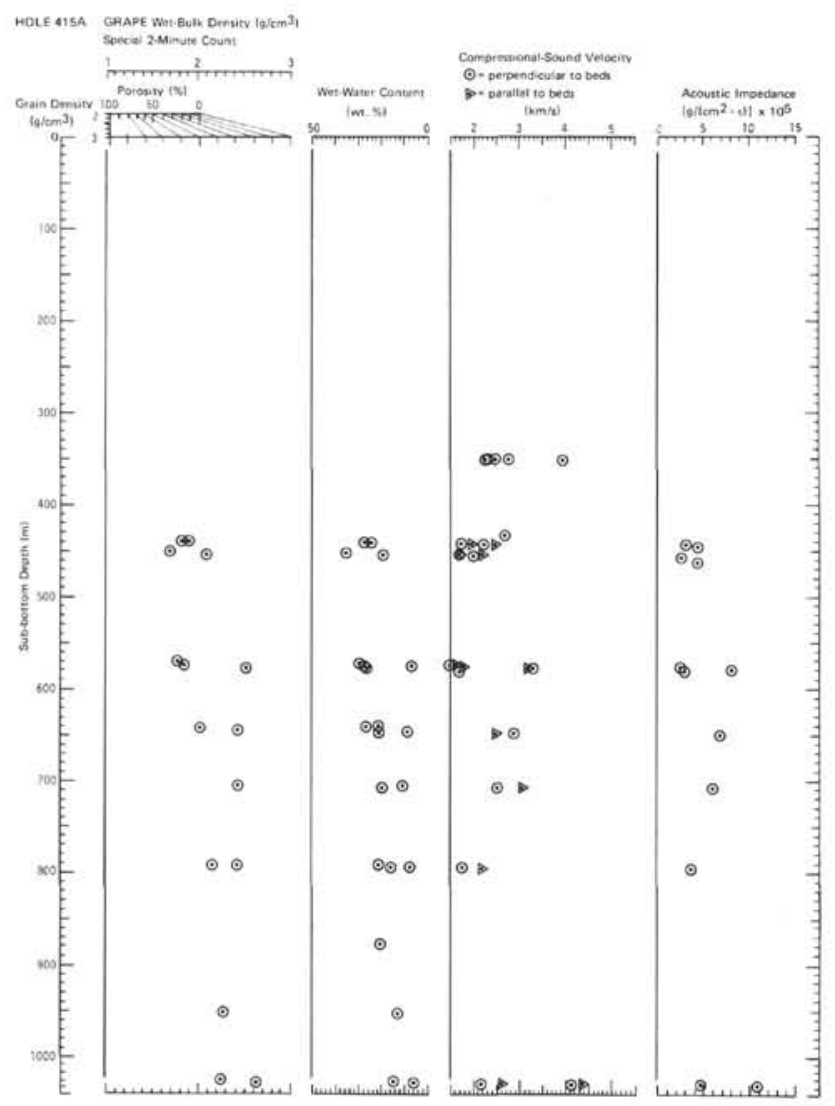

Figure 27. Physical properties and logging data versus depth, Hole 415A.

Miocene, the entire Oligocene, and the upper and middle Eocene. This is equivalent to a time span of as much as 29 m.y.

4. 178 meters (313-491 m) of Eocene and Paleocene mudstone and marlstone (Cores 415A-1 through 415A6 ). In the lower Eocene (Core 415A-1), calcareous nannofossils are common and poorly to moderately well preserved; in the Paleocene they are absent (Core 415A5 ), very rare (Core 415A-4), or common (Core 415A-6), and very poorly preserved, exhibiting fragmentation and signs of dissolution. Planktonic foraminifers are absent in the Paleocene of Cores 415A-4 and 415A-5; they are rare in the lower-Eocene of Core $415 \mathrm{~A}-1$ and in the lowermost Paleocene of Core 415A-6, in which planktonic-foraminifer tests are small and largely recrystallized. Rare and moderately well preserved radiolarians are present only in the two lowermost Paleocene cores (415A-5 and 415A-6).

A stratigraphic gap equivalent to a time span of approximately $3 \mathrm{~m} . \mathrm{y}$. appears to truncate the uppermost lower Paleocene. Included in the lower-Paleocene section there is an interval (415A-6-2, 27-33 cm) of allochthonous Maestrichtian nannofossil chalk.

5. An unconformity (or extremely condensed section) around 491 meters which probably eliminates most of the Upper Cretaceous. The hiatus covers a time span of possibly 20 m.y. Its extent, however, cannot be estab-

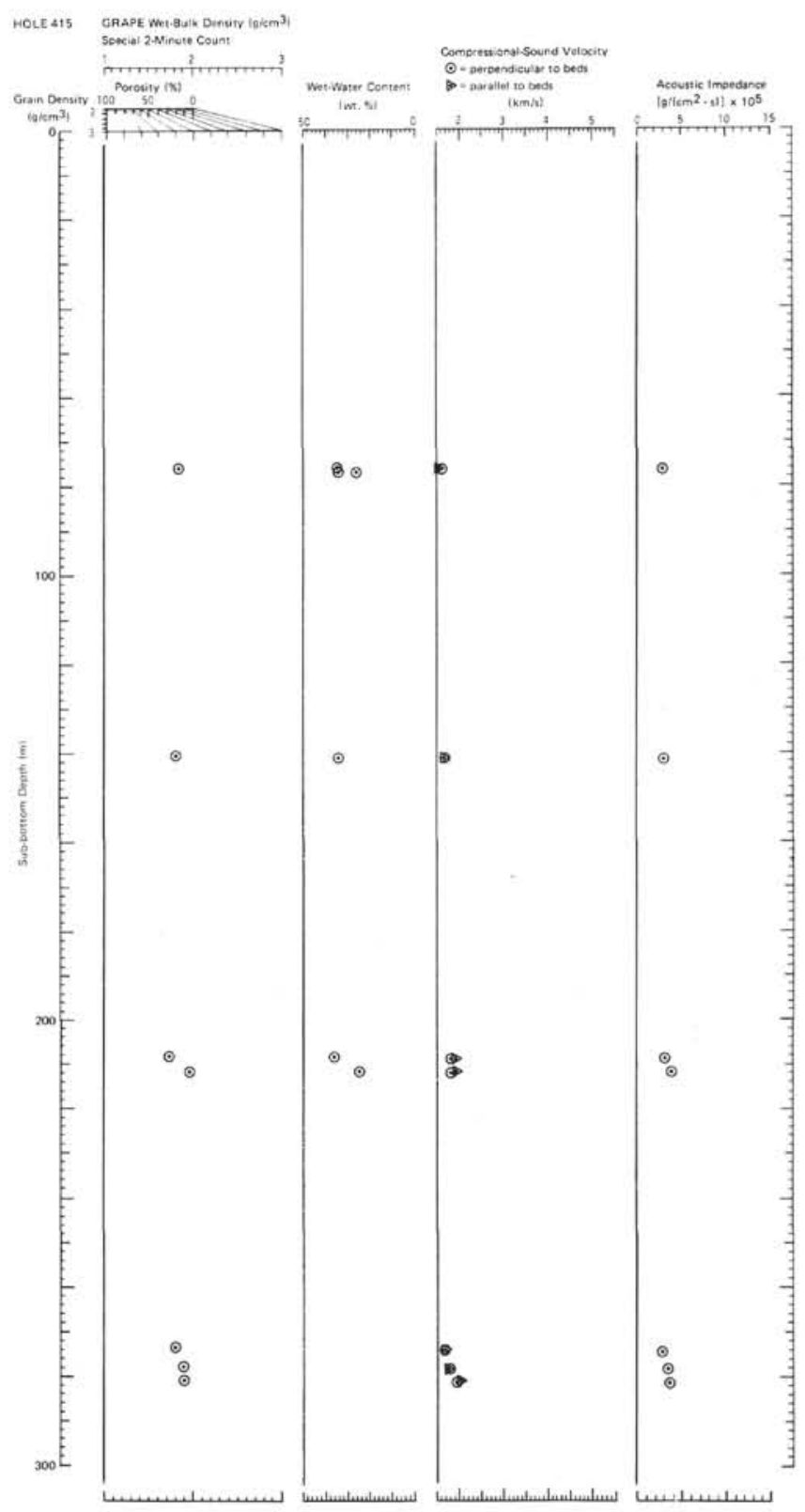

Figure 28. Data of Figure 26 at a larger scale.

lished, because of poor biostratigraphic control below the unconformity.

6. Approximately 86.5 meters (from about 491 to 577.5 meters) of pelagic clay (Cores $415 \mathrm{~A}-7$ through 415A-8, Section 1), barren of nannofossils and containing very rare specimens of the planktonic foraminifer Hedbergella, which indicates an age no younger than Coniacian and no older than Albian. Due to the uncertainty of the time interval represented by these sediments, an age range of Albian to Coniacian is indicated. In this dissolution facies, poorly preserved radiolarians are rare and filled with zeolites or recrystallized silica.

7. Five hundred and two meters (577.5-1079.5 m) of middle-Cenomanian to upper-Albian marlstone, with intercalations of limestone (Cores $415 A^{*}-8$, Section 2, through $415 \mathrm{~A}-15$ ) which contain rare and poorly preserved calcareous plankton showing significant dissolu- 

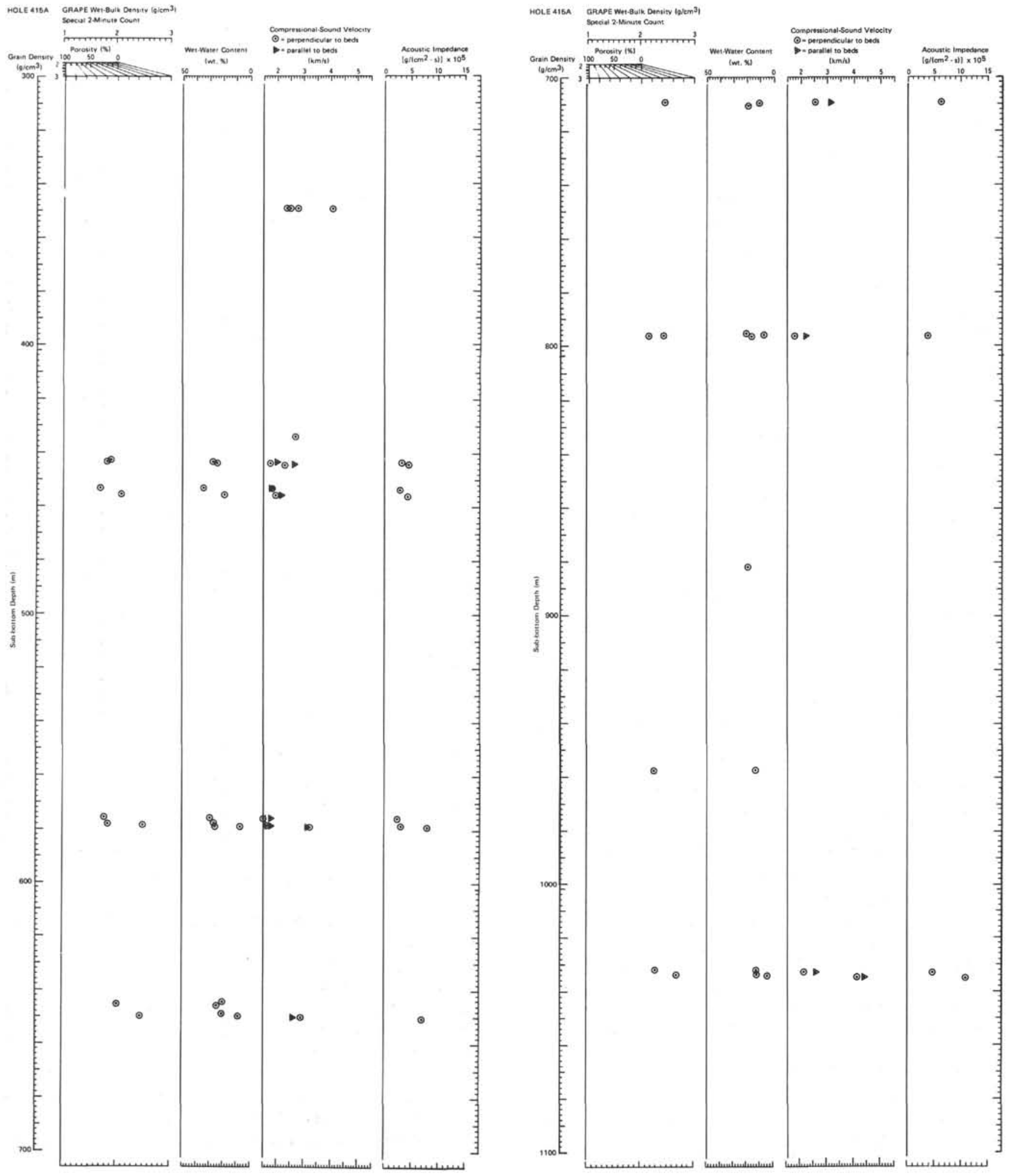

Figure 29. Data of Figure 27 at a larger scale. 


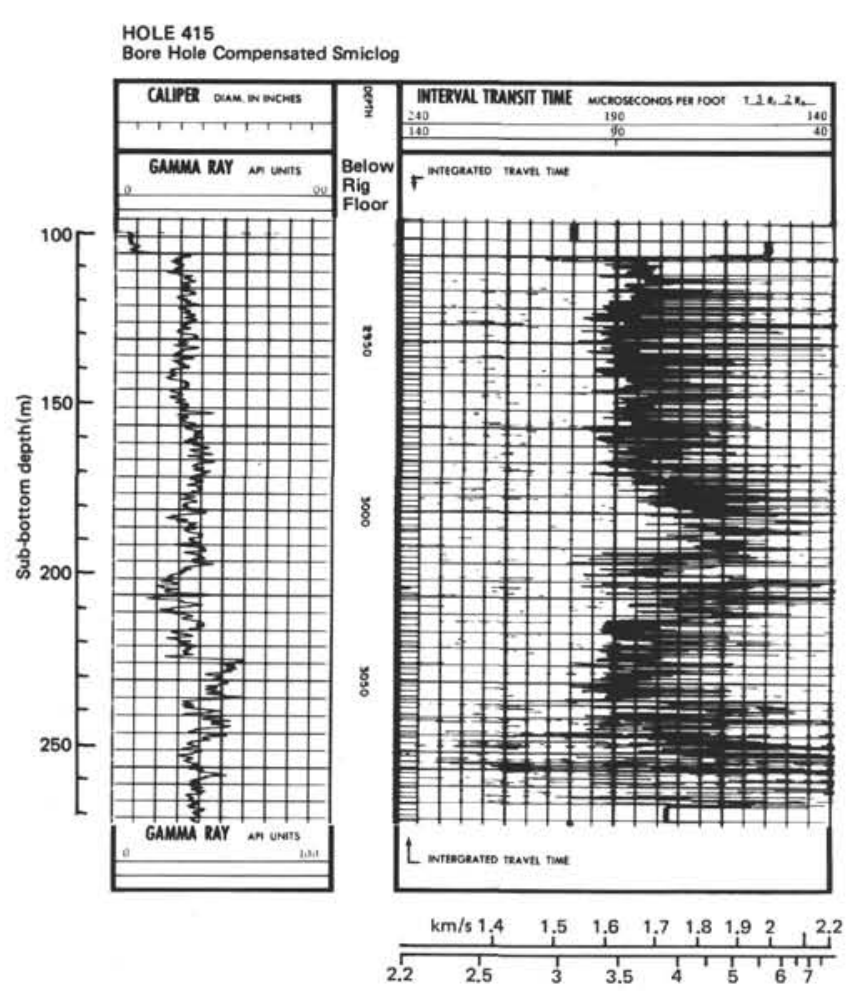

Figure 30. Borehole compensated sonic log and gamma-ray log of Hole 415. The dominantly dark velocity data are on the 1.4- to 2.2-km/s (740-140 micro$\mathrm{sec} / \mathrm{s})$ scale. To obtain an approximate depth below sea floor, subtract the water depth $(2807 \mathrm{~m})$ and subtract 10 meters from the depth indicated on the log.

tion. Foraminifers are small and are size-sorted, a characteristic of current-laid deposits. Radiolarians are rare and mostly calcitized.

The great thickness of the middle-Cenomanian section $(>300 \mathrm{~m})$ is remarkable. The sporadic and repetitious nature of the foraminifer fauna within this section and its cyclic preservation patterns, and the presence of disturbed bedding, suggest the effects of gravitational sliding and subsequent increased dissolution in the moreexposed or fractured intervals.

\section{Calcareous Nannoplankton}

\section{Pleistocene}

Pleistocene sediments were recovered only in the first core of Hole $415(0-7.5 \mathrm{~m})$. Nannofossils are abundant and well preserved. The assemblages from 415-1-1, 0-1 $\mathrm{cm}$ to $415-1-3,80-81 \mathrm{~cm}$ belong to the Emiliania huxleyi Zone (NN 21), the base of this zone being defined by the first occurrence of E. huxleyi. The core catcher of 415-1 contains Gephyrocapsa oceanica, but not E. huxleyi and Pseudoemiliania lacunosa; it therefore belongs to the Gephyrocapsa oceanica Zone (NN 20).

Core 415-1 contains one specimen of Cretarhabdus crenulatus, which is late Berriasian to Maestrichtian. No reworking from the earlier Tertiary was observed.

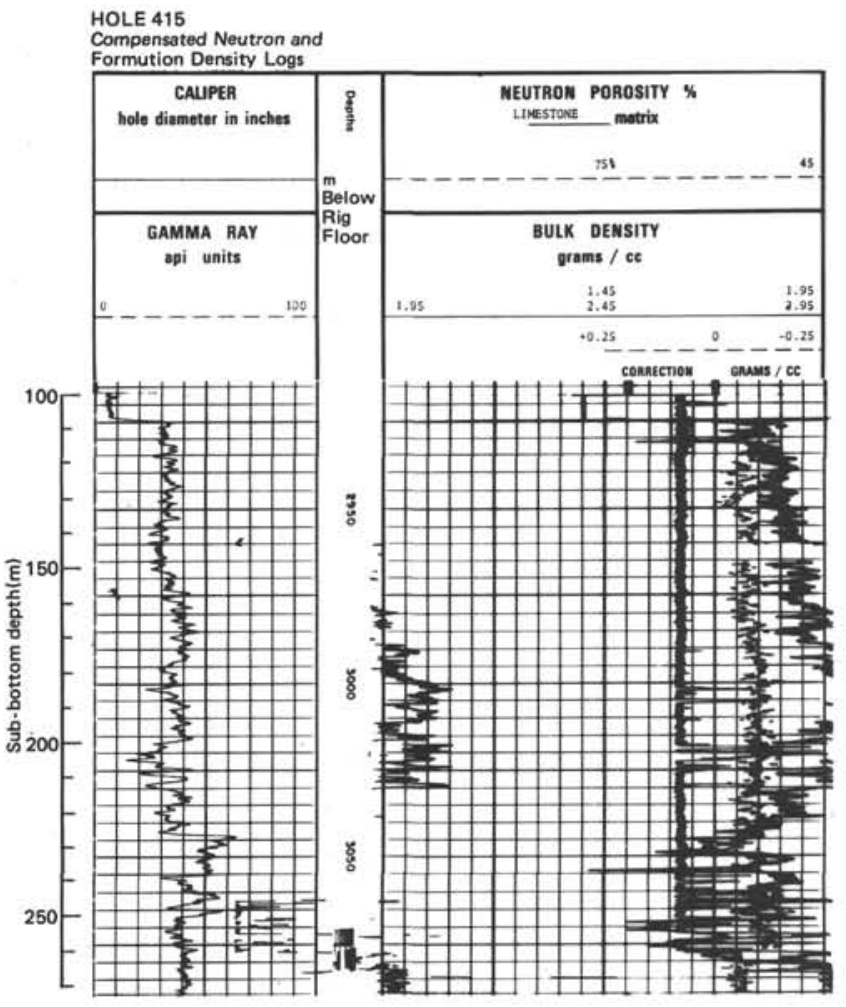

Figure 31. Compensated neutron-formation density and gamma-ray logs of Hole 415. At 2950 meters the three curves on the larger graph, from left to right, are (1) neutron, (2) correction applied to density data, and (3) density data. Approximate depth below the sea floor is equal to the depth on the log minus the water depth (2807 meters) and minus 10 meters.

\section{Pliocene}

Liner scrapings of Core 415B-1, Core 415B-2, and the uppermost part of Core 415-2 included Pliocene sediments (37.5 to $\sim 75.0 \mathrm{~m})$. Liner scrapings of 415B-1 represent the Discoaster surculus Zone (NN 16) of the early late Pliocene, with $D$. sp. cf. $D$. surculus, but without $G$. oceanica and Reticulofenestra pseudoumbilica. This determination should be interpreted cautiously because the sample might be contaminated. Core $415 \mathrm{~B}-2$ is placed in the interval of the $D$. surculus Zone (NN 16) to the Reticulofenestra pseudoumbilica Zone (NN 15) and contains specimens of $R$. pseudoumbilica. $P$. lacunosa and Ceratolithus rugosus are missing. The base of the lower Pliocene was recovered from 415-2-1, $32-33 \mathrm{~cm}$ to $415-2-1,62-63 \mathrm{~cm}$. In this interval, $C$. rugosus was observed without Discoaster asymmetricus and $D$. quinqueramus; $C$. rugosus is the marker species for the Ceratolithus rugosus Zone (NN 13).

The nannofossils of the Pliocene sequence are abundant and well preserved.

\section{Pliocene/Miocene Boundary}

The Pliocene/Miocene boundary is within the Ceratolithus tricorniculatus Zone (NN 12), which is the inter- 


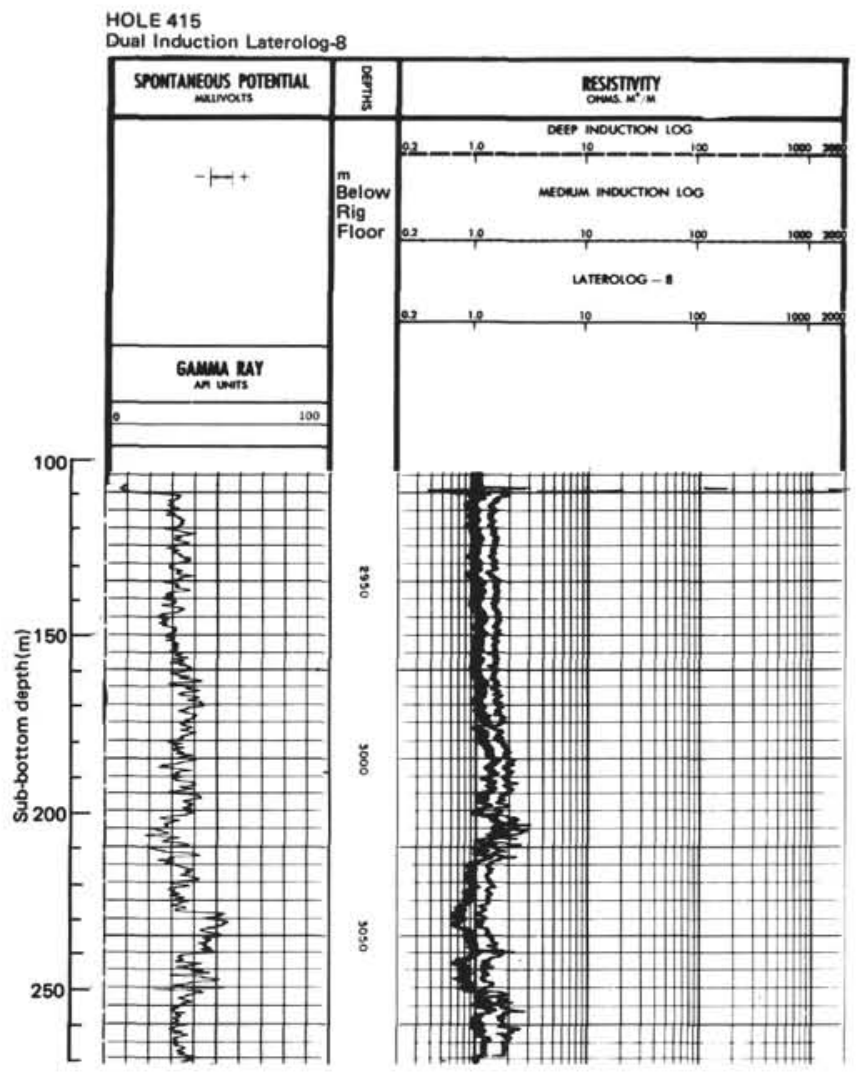

Figure 32. Dual induction-Laterolog-8 and gammaray log of Hole 415. Two basic lines are visible on the resistivity scale. The right heavy line is the Latero$\log -8$ data. The left heavy line is the combined data of the deep induction (left side) and medium induction data (right). Approximate depth below the sea floor is equal to the depth on the log minus water depth (2807 meters) and minus 10 meters.

val from the last occurrence of $D$. quinqueramus to the first occurrence of $C$. rugosus. This interval was recorded at $415-2-1,75-76 \mathrm{~cm}$ and $85-86 \mathrm{~cm}$. Missing from these samples were $C$. rugosus, $D$. quinqueramus, and C. tricorniculatus. The stratigraphic determination is based on the absence of $C$. rugosus, which is present in the top of the same core $(32-33 \mathrm{~cm}$ and $62-63 \mathrm{~cm})$ and which identifies the base of Zone NN 13, and on the absence of $D$. quinqueramus, which identifies Zone NN 11. The difficulty of recognizing Zones NN 13 and NN 12 at this site is due to the extremely poor recovery of specimens of Ceratolithus. The same problem with the rarity of Ceratolithus was noted at Site 397, and it is not known whether paleoenvironmental restrictions or dissolution effects are responsible for the extremely small number of specimens of this genus.

The calcareous nannoplankton of the Pliocene/ Miocene boundary interval is abundant and well preserved.

\begin{tabular}{|c|c|c|c|}
\hline Series & Cores & 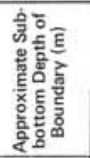 & Basis for Boundary Position \\
\hline Pleistocene & $415-1$ & \multirow[t]{2}{*}{32} & \multirow[t]{2}{*}{ Inferred from sedimentation rate } \\
\hline Upper Pliocene & $415 \mathrm{~B}-1$ & & \\
\hline Lower Pliocene & $415 \mathrm{~B}-2 \cdot 1,22 \mathrm{~cm}$ & 54 & Inferred from sedimentation rate \\
\hline 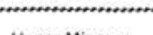 & $415 \cdot 2-1,102$ & 75 & Highest N17 sample \\
\hline Upper Miocene & $415 \cdot 2, \mathrm{CC}$ & \multirow{2}{*}{130} & \multirow{2}{*}{ Inferred from sedimentation rate } \\
\hline Middle Miocene & $415-3$ & & \\
\hline & $415-4.3$ & 211.5 & \multirow[t]{2}{*}{ NN $5 /$ NN 4 boundary } \\
\hline Lower Miocene & $\begin{array}{l}415-4-4 \\
415-5\end{array}$ & \multirow[b]{2}{*}{313} & \\
\hline Lone Fona & & & Inferred from gamma-ray log \\
\hline & & 381 & \multirow[t]{2}{*}{ Inferred from sedimentation rate } \\
\hline Upper Paleocene & $\begin{array}{l}415 A-4 \\
415 A-6-1,6\end{array}$ & \multirow{2}{*}{477.2} & \\
\hline Lower Paleocene & 415A-6-1, 7 & & Overlap of NP 3 and P3 \\
\hline & $415 A-6$ & \multirow[t]{2}{*}{491} & \multirow{2}{*}{ Inferred from gamma-ray log. } \\
\hline $\begin{array}{l}\text { Middle to Upper } \\
\text { Cretaceous }\end{array}$ & $\begin{array}{l}415 A-7 \\
415 A-8-1\end{array}$ & & \\
\hline Middle & $415 A \cdot 8 \cdot 2$ & 577.5 & Highest $R$. cushmani Zone sample \\
\hline Cenomanian & $415 A-12$ & \multirow{2}{*}{$\begin{array}{l}\text { tween } 883 \\
\text { and } 956\end{array}$} & \multirow{2}{*}{ Undetermined } \\
\hline $\begin{array}{l}\text { Lower } \\
\text { Cenomanian }\end{array}$ & $415 A-13$ & & \\
\hline & 415A-14 & 1000 & \multirow[t]{2}{*}{$\begin{array}{l}\text { Arbitrarily placed at mid-point } \\
\text { between cores }\end{array}$} \\
\hline Upper Albian & 415A-1E & & \\
\hline
\end{tabular}

Figure 33. Stratigraphic series at Site 415.

\section{Miocene}

The presence of Discoaster quinqueramus in Samples 415-2-2, 40-41 cm and 415-2-2,CC indicates the $D$. quinqueramus Zone (NN 11) at this level.

Middle- to lower-Miocene floras were recovered in the last three cores of Hole 415 (415-3 to 415-5; 145-283 m). Discoaster pentaradiatus suggests an age not older than middle Miocene (probably Zone NN 9) for the interval between 415-3-1, 109-110 $\mathrm{cm}$ and 415-3-3, 75-76 $\mathrm{cm}$. Discoaster pentaradiatus is missing in the 4153,CC, but Discoaster sp. cf. D. kugleri is present, which indicates a middle-Miocene age: Discoaster kugleri Zone (NN 7) to Catinaster coalitus Zone (NN 8).

The sediments of 415-4-2, 36-37 $\mathrm{cm}$ to 415-4-3, 69-70 $\mathrm{cm}$ contain Sphenolithus heteromorphus, but not Helicopontosphaera ampliaperta; this interval thus belongs to the Sphenolithus heteromorphus Zone (NN 5) of the early to middle Miocene. The placement of Cores 415-4-4 (bottom) and 415-5 (207-283 m) in Zones NN 4-NN 3 (Helicopontosphaera ampliaperta Zone-Sphenolithus belemnos Zone) is based upon the presence of $H$. ampliaperta (top of interval) and Sphenolithus heteromorphus (base of interval).

Nannofossils are abundant in Cores 415-3 and 415-4 and common in $415-5$, but preservation is poor to moderately good. No reworking was observed. Some overgrowths were found in Core 415-3. 


\begin{tabular}{|c|c|c|c|c|c|c|}
\hline \multicolumn{2}{|r|}{$\begin{array}{l}\text { Paleontological } \\
\text { Events }\end{array}$} & \multirow{2}{*}{$\begin{array}{c}\begin{array}{c}\text { Cores, } \\
\text { Site } 415\end{array} \\
415 \cdot 1 \cdot 5 / 415 \cdot 1 \cdot 6\end{array}$} & \multirow{2}{*}{\begin{tabular}{|c|}
$\begin{array}{c}\text { Sub-bottom } \\
\text { Depth } \\
\text { (m) }\end{array}$ \\
7.5
\end{tabular}} & \multirow{2}{*}{$\begin{array}{c}\begin{array}{c}\text { Age } \\
\text { (m.y.) }\end{array} \\
0.27\end{array}$} & \multicolumn{2}{|c|}{$\begin{array}{c}\text { Average } \\
\text { Sediment } \\
\text { Accumulation } \\
\text { Rate } \\
(\mathrm{m} / \mathrm{m} . \mathrm{y} .) \\
\end{array}$} \\
\hline 1 & NN $21 /$ NN 20 boundary & & & & 27.8 & \\
\hline 2 & Top G. margaritae & $4158 \cdot 2$ (upper) & Ca. 57 & 3.3 & & 17.8 \\
\hline 3 & $\begin{array}{l}\text { Bottom G. puncticulata } \\
\text { Bottom C. rugosus }\end{array}$ & $415 \cdot 2-1,63 \mathrm{~cm}$ & 74,63 & 4.2 & & \\
\hline \multicolumn{7}{|c|}{ Hiatus spanning approximately $2 \mathrm{~m} . \mathrm{y}$, at $75 \mathrm{~m}$} \\
\hline 4 & NN $9 /$ NN 8 boundary & 415-3-3 (base) & 141.5 & 11.5 & & \\
\hline 5 & NN $5 /$ NN 4 boundary & $415-4-3 / 415-4 \cdot 4$ & 211.5 & 15.5 & & 19.7 \\
\hline 6 & $\begin{array}{l}\text { Within the overlap } \\
\text { between S. wolffii Zone } \\
\text { and N.6 and NN } 3\end{array}$ & 415.5 (base) & 283 & 18.5-19 & & \\
\hline \multicolumn{7}{|c|}{ Probable hiatus spanning approximately $29 \mathrm{~m} . \mathrm{y}$. at $313 \mathrm{~m}$} \\
\hline 7 & Within NP 12 & 415A-1 (base) & 349.25 & 51.52 & & \\
\hline 8 & Within NP 8-NP 7 & $415 \mathrm{~A} \cdot 4$ (base) & 433.75 & 56.57 .5 & & 15.5 \\
\hline 9 & $\begin{array}{l}\text { Within the overiap } \\
\text { between P } 3 \text { and NP } 3\end{array}$ & $415 \mathrm{~A}-6-1,69 \mathrm{~cm}$ & 477.20 & 59.5-60 & & \\
\hline \multicolumn{7}{|c|}{ Probable hiatus spanning approximately $3 \mathrm{~m} . \mathrm{y}$. at $477.2 \mathrm{~m}$} \\
\hline 10 & Within NP 2 & $415 A-6, C C$ & ? & 63 & & \\
\hline \multicolumn{7}{|c|}{ Probable hiatus spanning approximately $20 \mathrm{~m} . \mathrm{y}$. at $491 \mathrm{~m}$} \\
\hline 11 & Within R. custmani Zone. & $415 \mathrm{~A}-8 \cdot 2,105 \mathrm{~cm}$ & 578.55 & $96-97.5$ & \multirow{2}{*}{\multicolumn{2}{|c|}{$\begin{array}{c}203 \\
\text { minimum }\end{array}$}} \\
\hline 12 & Within R. cushmsni Zone & 415A-12,CC & 883 & $96-97.5$ & & \\
\hline 13 & $\begin{array}{l}\text { Within } R \text {. brotzeni- } \\
\text { R. montsalvensis Zone }\end{array}$ & $415 A-13$ & $956-965.5$ & $97.5-100$ & \multicolumn{2}{|l|}{ ? } \\
\hline 14 & $\begin{array}{l}\text { Within } R \text {. appenninica- } \\
\text { P. buxtorfi Zone }\end{array}$ & $\begin{array}{l}415 A \cdot 14 \\
415 A \cdot 15\end{array}$ & $1032-1043$ & $100-102$ & \multicolumn{2}{|c|}{34.7} \\
\hline
\end{tabular}

Figure 34. Average sediment-accumulation rates at Site 415. Ages are taken from the time scales cited in the introductory chapter of this volume. Data for paleontological event 2 are from Hays et al. (1969), Berggren (1973), Saito et al. (1975), and Ryan et al. (1975), and for paleontological event 3 from Gartner (1973), Cita and Gartner (1973), Kennett and Watkins (1974), and Ryan et al. (1975). When a certain thickness interval or a time span is indicated for a paleontological event, the mid-point of the interval arbitrarily has been taken for calculation of accumulation rate.

\section{Early Eocene}

Lower-Eocene sediments were recovered only in Core 415A-1,CC (349-357.5 m). The species assemblage of Marthasterites tribrachiatus, Discoaster diastypus, $\mathrm{Zy}$ golithus dubius, and Discoaster lodoensis identifies the M. tribrachiatus Zone (NN 12) at this level.

The preservation and abundance of nannoplankton is the same as in the Miocene. No reworking, dissolution, or overgrowths were observed. Some fragmentation of nannoplankton was observed.

Cores $415 \mathrm{~A}-2$ and $415 \mathrm{~A}-3$ were without recovery.
Paleocene

Cores 415A-4 and 415A-6 (443-510 m) are considered early Paleocene. The core catcher of Core 415A-4 contains very poorly preserved (high fragmentation and dissolution) and very rare nannoplankton. The presence of Discoaster gemmeus (lower limit), and Fasciculithus tympaniformis (upper limit), and the absence of Discoaster multiradiatus (upper limit), indicate that this level belongs to the Discoaster gemmeus (NP 7) to Heliolithus riedeli (NP 8) zonal interval (late Paleocene). The core catcher of Core $415 \mathrm{~A}-5$ is barren of nannoplankton.

Lower-Paleocene specimens are few to common and show fragmentation, dissolution and poor preservation in Core 415A-6. The age of Sample 415A-6-1, 67-69 cm is identified as the Chiasmolithus danicus Zone (NP 3). The sample contains an assemblage with Chiasmolithus danicus, but without Ellipsolithus macellus and Fasciculithus tympaniformis.

From 415A-6-1, 74-75 cm to 415A-6-1,CC, Cruciplacolithus tenuis, Coccolithus cavus, Prinstus bisulcus, and Ericsonia subperbosa determine an early-Paleocene age, Cruciplacolithus tenuis Zone (NP 2). This age is derived from negative evidence, because no specimens of nannofossils species of a younger than Zone NP 2 were observed.

\section{Late Maestrichtian}

A nannofossil assemblage of the Micula muraNephrolithus frequens Zone was recognized in Samples $415 \mathrm{~A}-6-2,27-28 \mathrm{~cm}$ and $6-2,32-33 \mathrm{~cm}$. These samples do not contain an admixture of Cenozoic species. However, inasmuch as lower-Paleocene sediments occur above and below this level, the Maestrichtian sediments are interpreted as allochthonous.

\section{Late Albian-Cenomanian}

Lower Cretaceous sediments were recovered at Site 415 only in Hole 415A. The first Lower Cretaceous calcareous nannofossils were recovered in Section 415A8-2. The first section of this core and Core 415A-7 are barren of coccoliths. The identified nannofossils include Eiffellithus turriseiffeli, which indicates a maximum age of late Albian (E. turriseiffeli Zone). The upper boundary is Cenomanian, based on the presence of Parhabdolithus asper, but the typical species for the definition of the upper boundary of the Albian (e.g., Rucinolithus irregularis and Hayesites albiensis) or the Cenomanian (e.g., Lithraphidites alatus) are missing. The preservation of Cretaceous coccoliths from this hole is generally poor, except in $415 \mathrm{~A}-8, \mathrm{CC} ; 11, \mathrm{CC} ; 12$ and $15, \mathrm{CC}$. Dissolution occurs in most samples, and recrystallization in 415A-9-1, 61-62 cm. Abundance is relatively low, except in 415A-11,CC; 415-12; 13,CC, and $15, \mathrm{CC}$. 


\section{Foraminifers}

\section{Cenozoic}

\section{Coarse-Fraction ( $>63 \mu \mathrm{m}$ ) Components, Abundance and Preservation of Foraminifers}

Foraminifers are the dominant component of the coarse fraction of upper-Neogene sediments (upper Miocene to Quaternary). They are well preserved in the Pleistocene and Pliocene assemblages (Cores 415-1; 415B-1 and 2; upper $25 \mathrm{~cm}$ of $415-2$ ), in which planktonic species make up over 95 per cent of the foraminifer population, and less well preserved in the upper Miocene (remainder of Core 415-2). In the latter assemblages, fragmentation of planktonic tests is more pronounced, and benthic species constitute a greater proportion of the foraminifer population $(5-10 \%)$. Other components are rare and include pteropods (in the upper $43 \mathrm{~cm}$ of Core $415-1$ only), mollusk fragments, gastropods, and sponge spicules. Radiolarians and echinoderm debris are very rare. In upper-Miocene samples, glauconite and subangular quartz grains occur in noticeable abundance $(2-5 \%)$.

In middle- and lower-Miocene samples (Cores 415-3 to 415-5), biogenic siliceous components are more abundant; radiolarians and sponge spicules occur commonly. Glauconite is common. Subangular quartz grains are generally common, and very abundant in some layers. Volcanic glass occurs in the lower part of Core 415-3. Foraminifers are moderately well preserved. They are abundant in some intervals, in which they dominate the coarse fraction, whereas detrital components are dominant in others. Detrital quartz grains are particularly abundant in Samples 415-3-1, 25-27 cm; 415-4-2, 38-40 $\mathrm{cm}$; 415-4-4, 91-93 cm; 415-4-5, 60-62 cm; 415-5-1, 97-99 cm; 415-5-2, 58-60 cm; 415-5-5, 89-91 cm; and $415-5-6,17-19 \mathrm{~cm}$. Calcareous and siliceous rock fragments of pebble size, as well as pink calcite, occur in Sample $415-4-2,38-40 \mathrm{~cm}$. Chert fragments and pyrite were noted throughout most of Core 415-5. Displaced shallow-water material such as Balanus sp. and abraded Elphidium sp. are present in Sample 415-4,CC.

Eocene material was recovered only in the core catcher of Core 415A-1. Mud from the top of this core catcher yielded a very small amount of coarse fraction in which terrigenous components are dominant (small and large quartz grains; rock fragments including chert). Glauconite is rare. Foraminifers are common and dominated by benthic species. The planktonic-foraminifer fauna is poorly preserved and comprises small species. A thin section from one of the rock pebbles (\#6) contained in the gravel at the base of the core catcher shows the same components and the same foraminifer fauna and probably represents indurated sediments from the same formation.

Paleocene samples (Cores $415 \mathrm{~A}-4$ to $415 \mathrm{~A}-6$ ) are dominated by recrystallized calcareous aggregates. Radiolarians, partly replaced by calcite, are common; small, subangular quartz grains are rare to common, Cores $415 \mathrm{~A}-4$ and $415 \mathrm{~A}-5$ are barren of foraminifers, whereas Core $415 \mathrm{~A}-6$ contains common, although poorly preserved foraminifers. The fauna is dominated by benthic species. Planktonic species are small and commonly recrystallized.

\section{Planktonic-Foraminifer Zonation}

The presence of Globorotalia truncatulinoides throughout Core 415-1 indicates a Pleistocene age for this core, and the presence of pink specimens of Globigerinoides ruber as far down as $415-1, \mathrm{CC}$ indicates that it is not older than late Pleistocene. Changes in the relative abundance of warmer and colder elements of the fauna are evident in various levels of this core and reflect latePleistocene climatic changes. These variations may correlate with sediment color changes observed in that core. Layers with a colder fauna, characterized by a greater relative abundance of Neogloboquadrina pachyderma and the absence of pink Globigerinoides ruber, were observed in Samples 415-1-1, 41-43 cm and 415$1-1,127-129 \mathrm{~cm}$, from the olive-gray intervals.

Liner scrapings from Core 415B-1 yielded a Pleistocene fauna similar to Core 415-1, with common G. truncatulinoides and $G$. inflata (modern three-chambered morphotypes). Pink specimens of $G$. ruber were not found in this sample, and a few individuals of Globigerinoides obliquus s.1., a species known to have become extinct in the earliest Pleistocene, suggest an earliestPleistocene age for this sample. A Pleistocene fauna with common $G$. truncatulinoides was also found in the upper $7 \mathrm{~cm}$ of Core $415-2$, which very probably represents cavings from the upper part of the hole. Sediments from this interval have an olive-gray color distinct from that of the rest of the core.

Core 415B-2 contains an early-Pliocene fauna characterized throughout by Globorotalia puncticulata, Globoquadrina alispira, Sphaeroidinellopsis spp., and Globigerina nepenthes. Globorotalia margaritae was not found in the uppermost part of the core $(12-14 \mathrm{~cm})$, but it is present throughout the remainder of the core. It is assumed that the last occurrence of this species in the interval 32 to $34 \mathrm{~cm}$ represents its extinction level, which marks the boundary between Zones MPL. 4 and MPL. 3 of Cita (1975). On this basis, the top of Core 415B-2, without $G$. margaritae, is assigned to MPL.4, whereas the remainder of the core is assigned to MPL.3. Faunal assemblages of Core 415B-2 are dominated by $N$. pachyderma (dextral) and contain common $G$. bulloides and G. sacculifer. Rare but consistently occurring species include Sphaeroidinellopsis subdehiscens, S. seminulina, Globigerina apertura, Globigerinoides obliquus s.1., and Neogloboquadrina humerosa. Globigerina nepenthes and Pulleniatina primalis are very rare. Inverse variations in the relative abundance of the two species $G$. puncticulata and G. margaritae (common to rare) in various levels of the core are probably related to climatic changes during the time of deposition; horizons with a higher abundance of $G$. puncticulata reflect cooler conditions.

The upper $24 \mathrm{~cm}$ of Core $415-2$ contains a fauna similar to that of Core 415B-2, with the addition of the rare occurrence of members of the Globorotalia menardii group. G. puncticulata is rare but definitely present in this interval, which is thus assigned to MPL.3. The re- 
mainder of Core 415-2 appears to be late Miocene (N.17) on the basis of the rare occurrence of Globoquadrina dehiscens. Typical sinistral forms of $G$. margaritae were not found in the lower part of Core 415-2. However, rare dextral forms referred to $G$. sp. cf. $G$. margaritae were noted. Rare Globorotalia plesiotumida occur in the lower part of Core 415-2 where Globorotalia menardii (group) is common, suggesting for this interval warmer-water conditions than for that above. The warm-water forms Sphaeroidinellopsis spp. are rare however.

Core 415-3, which contains common Globorotalia mayeri, is middle Miocene. The presence of Globorotalia peripheroronda and of $G$. fohsi (group) indicates an N.12-N.13 age. Sphaeroidinellopsis subdehiscens was not observed in the bottom of Core 415-3, but it is present in the upper part (Section 1, 25-27 cm). The earliest occurrence of this species at the latter level marks the base of Zone N.13. Core 415-4 is assigned to Zone N.8-N.9 on the basis of the occurrence of Globigerinoides sicanus. Orbulinids were not observed in this core, but a few praeorbulinids were found. Core 415-5 contains a planktonic assemblage similar to that of Core 415-4, but without G. sicanus and with Catapsydrax dissimilis. Because of the co-occurrence of $C$. dissimilis and Globigerinoides sacculifer, this core is assigned to Zone N.6. Globorotalia siakensis, Globoquadrina dehiscens, and $G$. altispira occur commonly throughout Cores 415-3, 415-4 and 415-5.

Core $415 \mathrm{~A}-1, \mathrm{CC}$, which contains a poor planktonic fauna consisting mainly of Acarinina soldadoensis, is early Eocene (P.6-P.0). Core 415A-6 contains a relatively rich Paleocene planktonic fauna. Assemblages of Sections 1 and 2 of the latter core, which include Morozovella angulata, are assigned to Zone P.3, and those of 416A-6.CC, which include $M$. trinidadensis, are assigned to Zone P.1.

\section{Benthic Foraminifers}

Benthic foraminifers constitute more than 50 per cent of the foraminifer population in the Paleocene and Eocene sediments; they are less abundant in the Neogene assemblages, in which they constitute 10 to less than 1 per cent of the fauna. This change in the relative abundance of benthic species (less resistant to solution than planktonic species) is probably related to the position of the site relative to the foraminifer lysocline. The site was probably below the lysocline during the Paleocene and early Eocene (as reflected also by the low-diversity planktonic fauna), and well above during the Neogene.

Benthic species are dominated by calcareous forms which are mainly indicative of a bathyal environment. Miocene benthic species include Cibicides wuellerstorfi, Melonis pompiloides, M. barleeanus, Eggerella bradyi, Uvigerina hispida, Epistominella exigua, Sphaeroidina bulloides, Laticarinina pauperata, and large Pyrgo sp. Displacement of shallow-water forms (such as abraded Elphidium sp.) is noticeable in lower-Miocene sediments $(415-4, \mathrm{CC})$.

Lower-Eocene and Paleocene benthic assemblages are indicative of a middle bathyal environment. The shallower indicators of the lower-/Eocene fauna in Sam- ple 415A-1CC are Uvigerina, Plectofrondicularia and keeled tritaxia. Also present are deep-water species such as Aragonia aragonensis, Nuttalides trumpyi, and Oridorsalis umbonatus.

\section{Mesozoic}

\section{Zonation}

Cores $415 \mathrm{~A}-7$ to $415 \mathrm{~A}-8-2$ consist of olive to olivegreen mudstone and contain very rare agglutinated species and partly recrystallized fragments of the planktonic genus Hedbergella. These specimens date this interval as Albian to Coniacian. Cores $415 \mathrm{~A}-8-2$ to $415 \mathrm{~A}-12, \mathrm{CC}$ are regarded as from the middle-Cenomanian Rotalipora cushmani Zone. Foraminifers from Core 415A-8-2,CC are poorly preserved and include species of Clavihedbergella, Hedbergella, Praeglobotruncana, Schackoina, and Gubkinella. Core 416A-9 contains an increased planktonic fauna with somewhat better preservation, but dissolution and recrystallization strongly affect the calcareous species. Core $415 \mathrm{~A}-10$ for the most part is again strongly affected by dissolution. This interval of dissolution, and the presence of microfolds and slump structures in Cores $415 \mathrm{~A}-8$ to 10 , may represent the presence of gravity slide sheets that have disturbed the sediments and allowed renewed interstratal dissolution. Cores $415 \mathrm{~A}-11$ and 12 contain faunas that are among the most abundant and best preserved in the Cretaceous sections of Hole 415A; nevertheless, preservation remains poor to moderately good. Core $415 \mathrm{~A}-13$ is placed within the early-Cenomanian Rotalipora brotzeni/R. montsalvensis Zone. Preservation is poor to moderately good, and benthic species increase in number and diversity. Cores $415 \mathrm{~A}-14$ and 15 are late Albian and are assigned to the Rotalipora appenninica/Planomalina buxtorfi Zone. Preservation is again poor to moderate, and the low-diversity benthic faun contains species such as Gavelinella intermedia and Textularia foeda.

\section{Paleoecology}

Several broad paleoenvironmental trends are noted throughout the Cretaceous sequence. The site of deposition was apparently a deep-water environment of about 3000 to 4000 meters, as evidenced by a predominantly agglutinated fauna consisting of Recurvoides, Glomospira, Gaudryina, Textularia, Hyperammina, Ammodiscus, and Bathysiphon, among others. Elements of this assemblage are found in Cores $415 \mathrm{~A}-7$ through 415A-15. Upper-Albian to lower-Cenomanian outershelf to upper-slope sediments containing large nodosariids, fistulose polymorphinids, and worn miliolids were emplaced into this environment. These are followed by the cyclic sediments of Core 415A-10, which contain small planktonic and benthic foraminifers and probably represent distal fan deposits. Cores $415 \mathrm{~A}-7$ to 415A-9 complete the trend, with a gradual decrease of gravity-flow deposits and the appearance of sediments and faunas characteristic of deep-water dissolution facies. The younger Cenomanian faunas of Cores 415A-9, CC; 415A-10, CC; 415A-11; and 415A-12 stand out in being relatively diverse and consist predominantly of al- 
lochthonous upper to middle bathyal assemblages, as evidenced by nodosariids and species of Gavelinella, Gyroidinoides, Conorboides, Nodophthalmidium, Praebulimina, Ellipsoidella, and several large, agglutinated genera.

\section{Radiolarians}

Two samples from the Quaternary of Core 415-1 contained only very rare, poorly preserved orosphaerid fragments and indeterminate spumellarians.

A sample from 415B-2-1, 60-62 cm yielded no radiolarians, but samples from the Pliocene and Miocene of Cores 415-2 through 415-5 contained a sufficient number of moderately well-preserved radiolarians for stratigraphic interpretation. The assemblage in Core 415-2 apparently belongs in the Stichocorys peregrina Zone or the Spongaster pentas Zone, but the species necessary to distinguish the two zones are not present. Cores 415-3 and 415-4 belong in the Dorcadospyris alata Zone. Assemblages representing the Calocycletta costata Zone probably occur in the 60-meter unsampled gap between Cores 415-4 and 415-5, and the assemblages of Cores 415-5 belong in the Stichocorys wolffii Zone (the upper part of the former Calocycletta virginis Zone).

The lower Eocene of Core 415-1 contains no radiolarians, nor does the Paleocene of Core 415A-4. Rare, poorly to moderately-well preserved radiolarians occur in Cores 415A-5 and 415-6, indicating the unzoned part of the Paleocene older than the Bekoma bidartensis Zone.

Radiolarians are sparse and poorly preserved in the Cretaceous section. In three samples from Core 7 and the top of Core 8 , they are rare to very rare, filled with zeolite or recrystallized silica, and not identifiable. In the lower part of Core 8 through the top of Core 11, nine samples yielded no radiolarians. From Core 11-2 downward, radiolarians are very rare to rare and calcitized, with some recognizable forms. Core 11, CC yielded a pseudoaulophacid, Dictyomitra torquata, and doubtful specimens of Dictyomitra somphedia. Together, the four samples $415 \mathrm{~A}-12-2,53-55 \mathrm{~cm} ; 415 \mathrm{~A}-12$, CC; 415A-13-1, 135-137 cm; and 415A-13-2, 64-66 cm yielded Amphipyndax stocki, Dictyomitra macrocephala, D. torquata, D. veneta, Eucyrtis bulbosus, E. tenuis, and Stichomitra asymbatos. This interval probably belongs in the $D$. veneta Zone. Four samples from $415 \mathrm{~A}-13, \mathrm{CC}$ through $415 \mathrm{~A}-15, \mathrm{CC}$ contained very rare radiolarian fragments.

\section{SEDIMENTATION RATES}

Because of poor biostratigraphic control resulting from long unsampled intervals, sediment accumulation rates at Site 415 can be evaluated only in general terms. On the other hand, the few data points obtained throughout the section appear reliable, in view of the good agreement among age assignments based on various fossil groups. From these scattered data points, average accumulation rates have been estimated (Figure 34) using the time scales presented in the introductory chapters of this volume. Corrections for differential compaction have not been applied. Data from each fossil group are reported on Figure 35, on which a mean accumulation curve has been hand drafted.

A reliable datum point was obtained at about 74.63 meters with the coincident initial occurrence of Globorotalia puncticulata and Ceratolithus rugosus. Both these foraminifer and nannofossil events have been recorded at approximately the same level in Italian Pliocene type sections (Cita and Gartner, 1973) and have been paleomagnetically dated in extra-Mediterranean areas at about 4.2 m.y., within the Gilbert paleomagnetic Epoch (Gartner, 1973; Kennett and Watkins, 1974; Ryan et al., 1975). This date allows estimation of an average accumulation rate of about $18 \mathrm{~m} / \mathrm{m}$.y. for the 74.63 upper meters of the section. The last occurrence of Globorotalia margaritae at approximately 57 meters is in agreement with this value. The extinction level of the latter species has been recorded in paleomagnetically dated cores near the Gilbert/Gauss boundary at about 3.3 m.y. (Hays et al., 1969; Berggren, 1973; Saito et al., 1975; Ryan et al., 1975).

An average rate of accumulation of about $18 \mathrm{~m} / \mathrm{m} . \mathrm{y}$. can thus be confidently inferred for the Pliocene-Pleistocene section. Based on this value, the lower/upper Pliocene and Pliocene/Pleistocene boundaries are placed at 54 meters and 32 meters, respectively (Figure 8 ). The placement of the Pliocene/Pleistocene boundary at this level, slightly above Core 415B-1, is in agreement with the late-Pliocene age of the calcareous nannoplankton recovered in liner scrapings of this core. The foraminifer fauna of the same sample indicates a slightly lesser age (earliest Pleistocene), but, considering the poorly defined location of this sample, the disagreement between the floral and faunal date is not significant.

An age estimate of about 11.5 m.y. for the horizon at 141.5 meters indicates an average accumulation rate of about $9 \mathrm{~m} / \mathrm{m}$.y. for the lowermost Pliocene, upper Miocene, and upper middle Miocene section between 74.63 meters and 141.5 meters. Assuming a constant sedimentation rate between these two levels, the upper/middle Miocene boundary is placed at 130 meters. Age estimates of approximately 15.5 m.y. and 18.7 m.y. for the horizons at 211.5 and 283 meters, respectively, give an average accumulation rate of about $20 \mathrm{~m} / \mathrm{m}$.y. for the lower and middle Miocene between 141.5 and 283 meters.

It appears, then, that lower- to middle-Miocene sediments and Plio-Pleistocene sediments accumulated at a comparable rate (18 and $20 \mathrm{~m} / \mathrm{m} . y$. , respectively). In contrast, the late-Miocene rate of $9 \mathrm{~m} / \mathrm{m}$.y. is much reduced. If it is assumed that the Miocene section between Cores 415-2 and 415-3 accumulated at the same rate as underlying sediments $(20 \mathrm{~m} / \mathrm{m} . \mathrm{y}$.), the lower part of Core $415-2$ would be about 8.6 m.y. old, and a hiatus of about 4 m.y. would eliminate the upper part of the upper Miocene. Because of the widely spaced biostratigraphic data, it cannot be determined if the upperMiocene section is truncated by an unconformity, or if these strata are condensed. A clue is provided by the history of Neogene accumulation at Site 369 (off Cape Bojador, about $500 \mathrm{~km}$ southwest of Site 415 ; water depth $1762 \mathrm{~m}$ ), where continuous coring provided good 


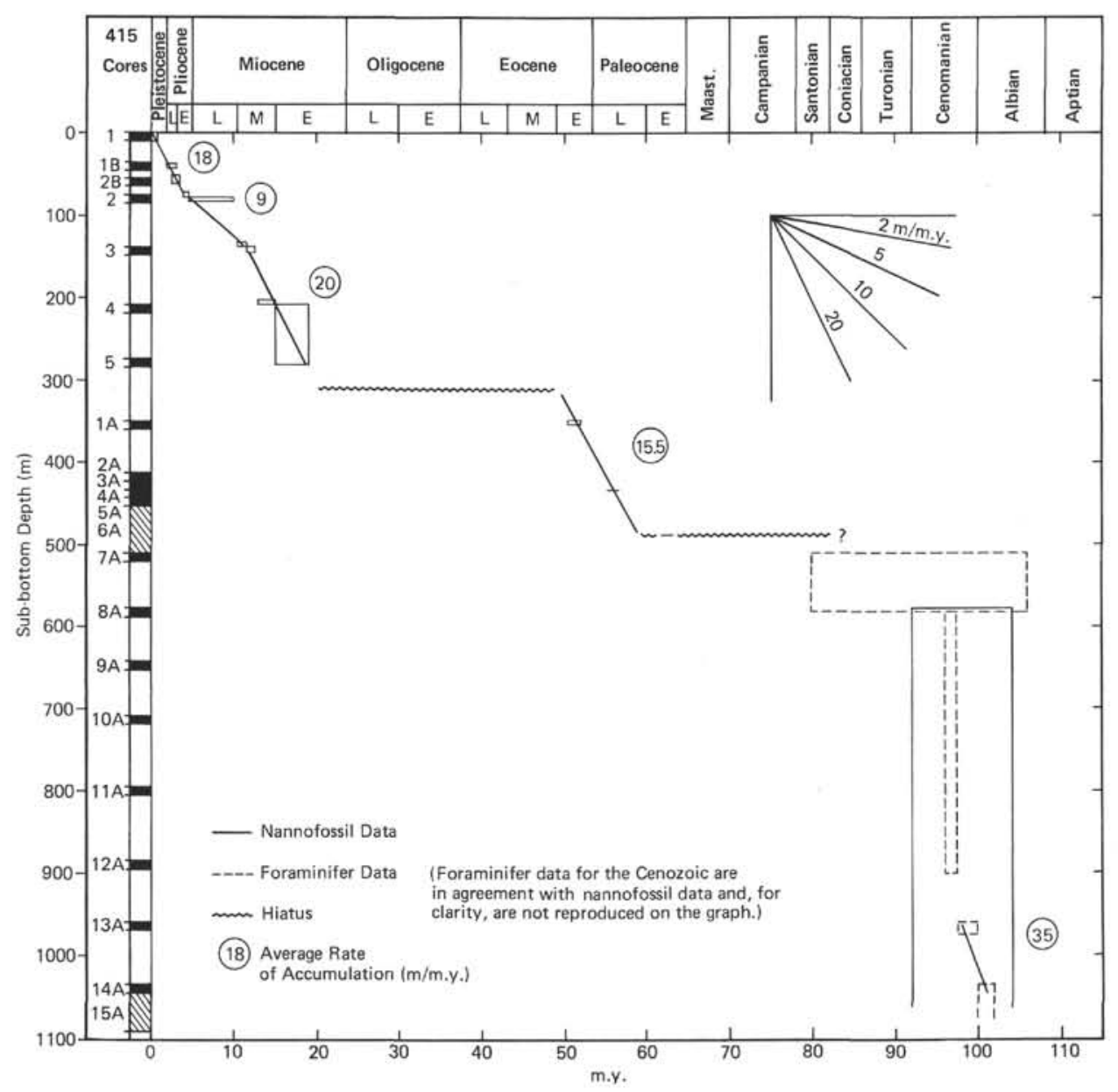

Figure 35. Sedimentation-rate curve for Site 415.

biostratigraphic control, and where, although there is no apparent stratigraphic gap at the Miocene/Pliocene boundary, the upper-Miocene sediments nonetheless accumulated significantly more slowly than underlying and overlying sediments. It is possible that the reduced upper-Miocene accumulation rate in the region of Sites 415 and 369 is related to an increase in calcium carbonate solution, as suggested by the poorer-than-average preservation of planktonic foraminifers in the lower part of Core 415-2.

The 66-meter-thick unsampled interval between Cores 415-5 and 415A-1 corresponds to the early Miocene to early Eocene and represents a time span of approximately $33 \mathrm{~m} . \mathrm{y}$. It is thus probable that one or more hiatuses occurs in this interval. The simplest interpretation of the available data is to place the unconformity arbitrarily at 313 meters (Figures 8 and 35 ), as suggested by the gamma-ray log.

Assuming that sediments between 313 and 349.25 meters accumulated at the same rate as underlying sediments (about $15.5 \mathrm{~m} / \mathrm{m} . \mathrm{y}$.), the strata just beneath the unconformity at 313 meters would be latest early Eocene (about $49.2 \mathrm{~m} . \mathrm{y}$. old), and by the same reasoning the strata just above would be $20.2 \mathrm{~m}$.y. old (early Miocene). A substantial hiatus thus would exist, encompassing the lowermost Miocene, the entire Oligocene, and the upper and middle Eocene, equivalent to a time span of approximately $29 \mathrm{~m} . \mathrm{y}$. Such a hiatus is represented on Figure 36. The extent of the hiatus, however, depends on the stratigraphic level of the unconformity, which could lie anywhere between the bottom of Core 415-5 (lower Miocene) and the top of Core 415A-1 (lower Eocene).

Age estimates of about 51 to 52 m.y. and 56 to 57.5 m.y. for the horizons at 349.25 meters and 433.75 , respectively, indicate an average accumulation rate of approximately $16 \mathrm{~m} / \mathrm{m}$.y. for the Eocene to Paleocene section between these two levels. Based on this value, the Eocene/Paleocene boundary is placed at 381 meters.

The position of Core $415 \mathrm{~A}-6$, cut between 452.5 and 509.5 meters, is not well defined. From the gamma-ray $\log$, however, the likely interval for this core is between 476.5 and 491 meters. The top of Core $415 \mathrm{~A}-6$ thus is placed arbitrarily at $\mathbf{4 7 6 . 5}$ meters (see Figure 8 ), and Sample $415 \mathrm{~A}-6-1,69 \mathrm{~cm}$ is therefore located at 477.20 meters. This sample, taken from the dark-gray layer just above a light-colored chalky interval (see Figure 16), falls biostratigraphically in the interval of overlap between Zones NP.3 and P.3, which spans an interval of time from 59.5 to 60 m.y. (earliest late Paleocene). This datum indicates an average accumulation rate of 14.5 $\mathrm{m} / \mathrm{m}$.y. for the upper Paleocene between 433.75 and 


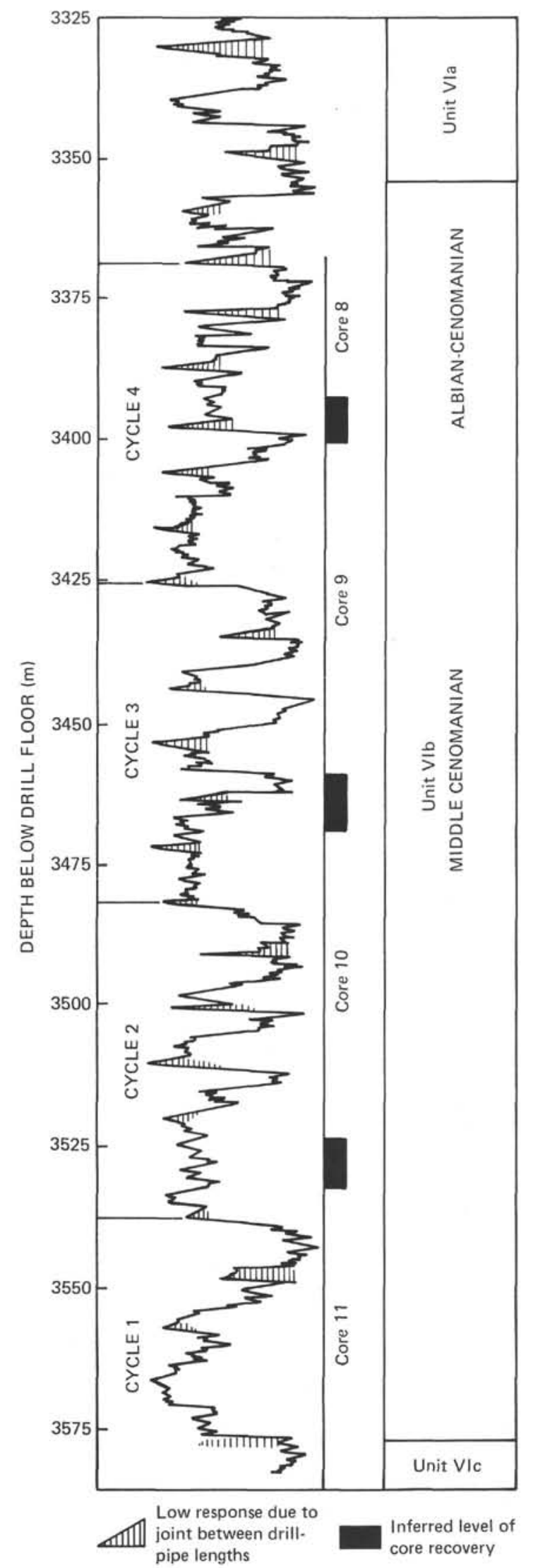

Figure 36. Gamma-ray log (taken behind the drill pipe) from 491 to 753 meters sub-bottom, Hole $415 \mathrm{~A}$.
477.2 meters. This value is comparable to the rate of the overlying interval $(16 \mathrm{~m} / \mathrm{m} . \mathrm{y}$.), and the entire Eoceneupper Paleocene sequence at the site accumulated at an average rate of $15.5 \mathrm{~m} / \mathrm{m} . \mathrm{y}$.

The Late Cretaceous hiatus between Cores 415A-6 and $415 \mathrm{~A}-7$ is placed at 491 meters, at the level of a distinct peak on the gamma-ray log. If a rate of 15.5 $\mathrm{m} / \mathrm{m}$.y. is assumed for the lower-Paleocene section between 477.2 and 491 meters, the sediments just above the unconformity would be about $61 \mathrm{~m} . \mathrm{y}$. old and would thus belong to Zones NP.3 and P.2. They are older, however, as evidenced by the recognition of Zones NP. 2 and P.1 in the interval between Sample 415A-6-1, $74 \mathrm{~cm}$ and 415A-6, CC. These data suggest the presence of a stratigraphic gap truncating the upper part of the lower Paleocene. This unconformity, equivalent to a time span of approximately 3 m.y., occurs in Core 415A, Section 1 at approximately $69 \mathrm{~cm}$, between a dark-gray marl and an underlying light-gray chalk (Figure 16). Stratigraphic disturbance in the lower Paleocene is evidenced by displaced Maestrichtian sediments in Core 415A-6-2, 27-33 cm.

No attempt is made to estimate sedimentation rates in the Cretaceous section, because of the lack of paleontological data and the evidence of stratigraphic disturbance. The extent of the Late Cretaceous hiatus cannot be established, because of the uncertainty of the time interval represented by the sediments below the unconformity.

It appears, however, that these sediments between 491 and 577.5 meters accumulated slowly. The combination of a low sedimentation rate, strong carbonate dissolution, and development of zeolites correlates these sediments with the dissolution facies or barren interval that characteristically extends from the late Cenomanian to the middle Santonian in oceanic sediments (Sliter, 1976, 1977).

The interval from 577.5 to 883 meters is attributed to the middle-Cenomanian $R$. cushmani foraminifer zone, which spans an interval from 96 to $97.5 \mathrm{~m}$.y. This age assignment indicates a minimum accumulation rate of $203 \mathrm{~m} / \mathrm{m}$.y. for this interval. This extremely high rate obviously does not reflect pelagic deposition at the site during this time and is probably a result of gravitational sliding, as suggested by the cyclic and repetitious nature of the foraminifer fauna and the lithologic disturbance.

The Albian/Cenomanian boundary occurs in the interval between 1032 and 965.5 meters. It is arbitrarily placed at the mid-point of this interval, at 1000 meters. Based on this assumption the lower part of the sedimentary sequence (lower Cenomanian and upper Albian) accumulated at the relatively high rate of about $35 \mathrm{~m} / \mathrm{m} . \mathrm{y}$.

\section{COMPARISON OF SEISMIC- REFLECTION PROFILES WITH DRILLING AND LOGGING RESULTS}

Several high-quality seismic-reflection profiles have been obtained in the vicinity of Site 415 , and even though the hole was terminated before reaching the deeper objectives, the results of both drilling and logging can be used to correlate the most prominent reflectors with the lithology. 
Four seismic lines passing very close to Site 415 are available for this correlation: (1) the two single-channel profiles run by Glomar Challenger during the approach to the site (Figures 6 and 7), and (2) the two multichannel profiles run by Phillips Company Ltd. (SSL, line 20; Figure 3) and by Bundesanstalt für Geowissenschaften und Rohstoffe (Meteor 3902) (Figure 2), respectively. Both the Glomar Challenger and Meteor profiles are presented in a separate chapter on underway geophysics in this volume.

Several estimates of interval velocities were obtained by K. Hinz (personal communication) from the Meteor line and proved particularly valuable in interpreting the drilling and logging results. They are discussed, together with the regional acoustic stratigraphy, in the background and objectives section of this chapter.

Because only the upper part of the section actually has been sampled and partially logged, our interpretation is based mostly on the Glomar Challenger profiles (Figures 6 and 7). These records were made on two crossings of the west slope of the Agadir Canyon, the first about $1 \mathrm{~km}$ south of Site 415 , and the other a roughly equal distance to the north (Figure 4). To estimate the two-way reflection time to where reflectors should be beneath Site 415 , the averages of the times measured from the sea floor to reflectors on the two crossings are used. The sea floor depth is taken as that at the site (3.71 s).

Using this method, the two-way times to reflectors that may have been reached by the drilling at Site 415 are as follows:

$\begin{array}{ll}\text { Brown Reflector: } & 0.245 \mathrm{~s} \\ \text { Red Reflector: } & 0.500 \mathrm{~s} \\ \text { Orange Reflector: } & 1.145 \mathrm{~s}\end{array}$

Using several different classes of evidence, estimates can be made of the most plausible depth and stratigraphic position of each of these reflectors.

\section{Brown Reflector}

Several lines of evidence point to the brown reflector being at the top of a series of well-cemented sandy or shelly layers close to the boundary between the middle and lower Miocene, at a sub-bottom depth of about 200 meters at Site 415. First, we have the evidence of the various Schlumberger logs. The sonic log run in Hole 415 shows that velocities are low - mainly between 1.52 and $1.78 \mathrm{~km} / \mathrm{s}$ - in the upper part of the logged interval (108 to about $170 \mathrm{~m}$ ), and it is probable that velocities still closer to the sea floor are nearer the lower end of this range. For example, an initial estimate of the interval velocity from sea floor to brown reflector of 1.61 $\mathrm{km} / \mathrm{s}$ gives a reflector depth of 197 meters. Each 0.01 $\mathrm{km} / \mathrm{s}$ change shifts the depth by about 1 meter. We thus start by looking near 197 meters.

On the gamma-ray log, there is a pronounced decrease in intensity at about 199 meters, accompanied by a corresponding large increase in velocity shown on the sonic log, as well as by a marked increase in resistivity on the Laterolog, and by the top of a series of spikes on the neutron porosity log. A fairly abrupt lithologic change is thus indicated, and the combination of log features suggests cemented sandstone or limestone.

This lithologic inference is supported by evidence from Core 415-4, at about 207 to 216.5 meters, which contained thin layers of well-cemented, redeposited coquina limestone interbedded with nannofossil chalk and marl. The Schlumberger logs suggest that this core comes from the lower part of a 15-meter-thick sequence with coherent logging characteristics.

The drilling-rate diagram (Figure 8) shows a steady slowing from 150 to about 190 meters, then nearly uniform slow progress through Core 415-4.

Another choice for the brown reflector is at $238 \mathrm{me}-$ ters, where the gamma-ray log shows an abrupt decrease in radiation below an 11-meter-thick interval with abnormally high gamma radiation. A marked increase also shows at nearly this same level on both the sonic and resistivity logs, while drilling rates show an abrupt decrease. The computed interval velocity from the sea floor to 238 meters, using 0.245 -second reflection time, is $1.942 \mathrm{~km} / \mathrm{s}$, a value that appears rather too high to fit the sonic log. The preferred identification of the brown reflector is thus at about 200 meters, and the corresponding computed interval velocity from the sea floor is $1.63 \mathrm{~km} / \mathrm{s}$.

\section{Red Reflector}

We have no sonic log of the strata deeper than about 275 meters as a guide to interval velocities. The laboratory measurements on Cores $415 \mathrm{~A}-4,415 \mathrm{~A}-5$, and $415 \mathrm{~A}-6$ suggest an interval velocity between the brown and red reflectors ranging from 2.0 to $2.4 \mathrm{~km} / \mathrm{s}$, but the data are sparse. The stacking velocities derived from the 24 -fold seismic-reflection survey for the brown-to-red interval in the region close to Site 415 range from about 2.35 to $2.7 \mathrm{~km} / \mathrm{s}$. Assuming 200 meters for the depth to the brown reflector, and 0.255 seconds for the two-way time between brown and red, the depth to the red reflector is 475 meters, and the interval velocity is $2.15 \mathrm{~km} / \mathrm{s}$. Using the interval-velocity range of 2.3 to $2.7 \mathrm{~km}$, the computed depth would be between 493 and 544 meters. The maximum reasonable range of values is therefore 475 to 544 meters.

On the gamma-ray log, there is a very sharp spike of about 110 counts/min at 491 meters, suggesting a layer of unusual mineralogy. Below this depth gamma counts commonly exceed $70 / \mathrm{min}$, whereas higher up, with very minor exceptions, values typically are around 40 to 50 counts/min.

The core data suggest an unconformity between $\mathrm{Pa}$ leocene and Cenomanian beds at or a little above the level of Core 415A-7, which begins at 509.5 meters. Core 415A-6, which was entirely Paleocene, cannot be fixed at a specific depth within the interval 452 to 509.5 meters. Core 415A-7 contained some Paleocene nannofossils at the top of the core and Cretaceous radiolarians in the core catcher, but the lithology of the mudstone, even near the top of the core, strongly resembles that of the mudstone in the Cretaceous beds below. Neither the 
laboratory data on density and velocity nor the drillingrate data give much indication of an important lithologic break between 475 and 550 meters, possibly excepting a slight slowing of penetration rate in the interval from 470 to 490 meters.

Precise identification of the red reflector using the data from this site thus eludes us. On the other hand, this reflector has been correlated with an unconformity between Paleocene and Eocene layers at Site 416 (Site 416 report, this volume). At Site 415 , the Paleocene layers extend at least as high as 443 meters and perhaps 414.5 meters, and it is unlikely that the red reflector would correspond to the same stratigraphic horizon. The most reasonable location for this reflector appears to be somewhere between 475 and 491 meters, and the interval velocity would accordingly vary from 2.16 to $2.28 \mathrm{~km} / \mathrm{s}$.

\section{Orange Reflector}

Measurements on core samples from Hole 415A are too few to provide a solid basis for estimating an interval velocity between the red and orange reflectors. The mudstone was commonly just gassy enough to interfere with sound transmission; the harder, more calcareous rocks give good values, ranging from 2.6 to $3.6 \mathrm{~km} / \mathrm{s}$, but the proportion of this type of rock in situ is unknown.

Various stacking velocities for the red-orange interval obtained along the unpublished GSI profile and the Meteor line are in the range of 2.2 to $2.6 \mathrm{~km} / \mathrm{s}$, and if we accept the red reflector depth as 491 meters, the orange reflector would be expected between 1200 and 1330 meters, some 120 to 250 meters below the total depth reached at Site 415 .

On the other hand, the hard, well-stratified calcarenite in Core 415A-15, from the interval 1041.5 to 1079.5 meters (but more likely from 1070 to 1079.5 meters as judged from the very slow drilling rate), is a plausible candidate for the top of the orange reflector, if such layers are frequent below this level. The shale in Core $415 \mathrm{~A}-14$ is highly fractured, whereas the calcarenite in Core $415 \mathrm{~A}-15$ is unfractured, suggesting that the base of the slide mass described in the lithology section lies between the two cores. The seismic-reflection character of the red-orange interval consists of a confusing combination of diffractors and discontinuous, slightly inclined reflectors, in contrast to the highly stratified reflectors that underlie the orange reflector. This disturbed internal structure is consistent with the lithologic and biostratigraphic data, which point to a sequence of slumps or slide sheets from Core 415A-7 through Core 415A-14. However, if we fix the base of the slide sequence at 1070 meters, then the red-orange interval velocity would be only $1.80 \mathrm{~km} / \mathrm{s}$, a value that is clearly out of line with the stacking velocities from the multifold seismic line and from the laboratory data. This interpretation further implies a large velocity reversal below the red reflector. In light of these difficulties, the conclusion is that the drill probably never reached the orange reflector at Site 415, and that the reflector is likely at least as old as Aptian.

\section{SAFETY AND POLLUTION-PREVENTION PROGRAM}

\section{Hole 415}

No hydrocarbon fluorescence or cut was observed in any of the five cores taken in Hole 415.

Data on gas samples obtained from Cores 415-3 and 415-5 appear in Table 9.

\section{Hole 415A}

Each core from Hole 415A was monitored for hydrocarbons, utilizing all available methods of observation. In the Cenozoic, Cores 415A-1 through 415A-4 were not analyzed, owing to no or very little recovery. The high $\mathrm{C}_{1} / \mathrm{C}_{2}$ ratios of all measured sediments in the Cenozoic and the pyrolysis measurement on Core $415 \mathrm{~A}-5$ indicated poor source rocks for hydrocarbon generation and no evidence of proximity to any significant hydrocarbon accumulations.

Seven cores were taken within the Cretaceous. The obtained results appear in Table 10. The "quick" gas analysis indicated a major decrease in the $C_{1} / C_{2}+$ ratio between Cores 415A-10 and 415A-11. Core 415A-10 had a $C_{1} / C_{2}+$ ratio of 1135 , while Core $415 \mathrm{~A}-11$ had a ratio of 567. The ratio remained between 400 and 500 through the final core, $415 \mathrm{~A}-14$. While this rapid narrowing of the $C_{1} / C_{2}+$ ratio could have been a cause for alarm, the quantities of $\mathrm{C}_{2}-\mathrm{C}_{5}$ were still relatively low, and the $C_{1} / C_{2}+$ ratio was not yet at a critical level. Also, the data from pyrolysis of samples from Cores

TABLE 9

Hydrocarbon Monitoring in Hole 415

\begin{tabular}{ccccccc}
\hline Core & $\begin{array}{c}\text { Interval } \\
(\mathrm{m})\end{array}$ & Series & Lithology & $\begin{array}{c}\mathrm{CH}_{4} \\
(\%)\end{array}$ & $\begin{array}{c}\mathrm{C}_{2}-\mathrm{C}_{5} \\
(\mathrm{ppm})\end{array}$ & $\mathrm{C}_{1} / \mathrm{C}_{2}+$ \\
\hline $415-3$ & $2954.5-2964$ & $\begin{array}{l}\text { M. Miocene } \\
\text { L. Miocene }\end{array}$ & $\begin{array}{l}\text { Nannofossil marl } \\
\text { Nannofossil ooze } \\
\text { and marl with } \\
\text { siliceous debris }\end{array}$ & $\begin{array}{l}0.032 \\
0.50 .5-3100\end{array}$ & $\mathrm{C}_{2}=2.9$ & 1100 \\
\hline
\end{tabular}

TABLE 10

Hydrocarbon Monitoring in Hole 415A

\begin{tabular}{|c|c|c|c|c|c|c|}
\hline Core & $\begin{array}{l}\text { Interval } \\
\text { (m) }\end{array}$ & Fluor. & GQF & $\begin{array}{c}\text { Methane } \\
(\%)\end{array}$ & $\mathrm{C}_{1} / \mathrm{C}_{2}{ }^{+}$ & Pyrolysis Data \\
\hline $415 \mathrm{~A}-8$ & $\begin{array}{l}3336- \\
3402.3\end{array}$ & 0 & $3-4$ & 16.7 & 1156 & - \\
\hline $415 A-9$ & $\begin{array}{l}3459.3- \\
3469\end{array}$ & 0 & 4 & 68.5 & 3166 & - \\
\hline $415 \mathrm{~A}-10$ & $\begin{array}{l}3526- \\
3535.5\end{array}$ & 0 & 2 & $\begin{array}{l}29.8^{*} \\
57.5\end{array}$ & $\begin{array}{l}953^{*} \\
1135\end{array}$ & - \\
\hline $415 \mathrm{~A}-11$ & $\begin{array}{l}3611.5- \\
3621\end{array}$ & 0 & 2 & 17.4 & 567 & - \\
\hline $415 \mathrm{~A}-12$ & $\begin{array}{l}3697- \\
3706.5\end{array}$ & 0 & 5 & 39.8 & 438 & - \\
\hline $415 \mathrm{~A}-13$ & $\begin{array}{l}3773- \\
3782.5\end{array}$ & 0 & 4 & $\begin{array}{l}42.6 \\
30.4^{*}\end{array}$ & $\begin{array}{l}588 \\
369^{*}\end{array}$ & $\begin{array}{l}\text { Very little generated } \\
\text { hydrocarbons, little } \\
\text { potential. Type } 3 \\
\text { kerogen, poor source. }\end{array}$ \\
\hline $415 \mathrm{~A}-14$ & $\begin{array}{l}3849- \\
3858\end{array}$ & 0 & 3 & $\begin{array}{l}62.4 \\
59.8^{*}\end{array}$ & $\begin{array}{l}514 \\
402 *\end{array}$ & $\begin{array}{l}\text { Very little generated } \\
\text { hydrocarbons, very } \\
\text { small potential. Type } \\
2-3 \text { kerogen, poor } \\
\text { source. }\end{array}$ \\
\hline
\end{tabular}

"gas sample measured after waiting one or more hours to sample from plastic liner. 
415A-13 and 415A-14 indicated that the sediments contain little generated hydrocarbons and that the kerogens were Type $2-3$; thus, we considered the rocks a poor source. Also, the degree of maturation was still low. Core $415 \mathrm{~A}-14$ was still in the immature stage, but was approaching maturity.

Immediately prior to abandonment of Site 415 , preparations were underway for continuous coring operations as a safety measure. The increase in $\mathrm{CH}_{4}$ and the narrowing of $\mathrm{C}_{1} / \mathrm{C}_{2}+$ ratio resulted in a very careful scrutiny of each core by all three methods of observation, but no indications had been encountered that would have led to abandonment for safety reasons.

The combination of visual observation, gas analyses, and pyrolysis seems to be the most viable method yet devised of maintaining a safety program while drilling.

\section{SUMMARY AND CONCLUSIONS}

Given that the main objective at this site was to sample deeply buried Jurassic sediments, the results obviously fall short of what was expected. Bad drilling conditions forced us to abandon the site after having reached Albian sediments at a sub-bottom depth of 1079.5 meters.

Nevertheless, the three holes drilled at this site proved to be more than a mere exercise, and they yielded important new insights on regional questions such as the evolution of the Canary Islands area and the interpretation of the acoustic stratigraphy of the Moroccan Basin, as well as on fundamental topical problems such as largescale intraformational tectonics.

The sedimentary section was sampled in three successive holes. The first hole (415) was a 283 -meter-deep pilot hole to test the frictional resistance of the sediments in which we planned to emplace the re-entry cone and casing assembly. The principal hole $(415 \mathrm{~A})$ was drilled to the final depth after three successive reentries, of which two were required for placing casing in the upper part of the hole and one for an attempt at improving drilling conditions in the lower section. The third hole (415B) was purely accidental and caused by a temporarily undetected missed re-entry after the emplacement of the $113 / 4$-inch casing.

Because of the proximity of Site 370, where the upper 1176 meters of the sedimentary section had been relatively closely sampled, coring at Site 415 was very dis continuous. Cores were taken at approximately 70 meter intervals, mainly to monitor possible hydrocarbon occurrences and the state of maturation of organic matter, so as to establish the trends necessary to evaluate potential hazards in the deeper part of the section. From the spot cores we can nevertheless attempt a schematic reconstruction of the geologic evolution of the area since the late Albian.

We divide the sampled section into three major intervals that correspond with rather well-differentiated phases separated by hiatuses: Mesozoic (Albian-Cenomanian and undifferentiated Upper Cretaceous, possibly up to Coniacian); Paleogene (Paleocene-lower Eocene); and Neogene (lower Miocene to Quaternary).

\section{Mesozoic}

The Mesozoic section consists primarily of marlstone, with occasional intercalations of more-or-less dolomitic limestone layers or laminae. The lithology of these sediments and the contained microfossils indicate deep-water environments, with regular influxes of material from shallow-water environments at the base of the section. Upward, this influx of redeposited material changes both in quantity and in kind; gradually, shallow-water (shelf) microfossils are replaced by material from moderately deep water (slope), and finally both kinds disappear.

The sedimentary environment during Albian through middle-Cenomanian time appears to be that of a deep (3000-4000 m) basin, in which predominantly hemipelagic sediments were deposited below the CCD. Terrigenous materials were continuously supplied, but in variable amounts that decrease regularly upward. These thin laminae of quartzose silt are common, and clay is omnipresent, but some layers consist of coarse-grained detrital material such as shelf-derived quartzose calcarenite.

The stratigraphy of this interval shows unusual features. Several lines of evidence indicate that this part of the section has been subject to post-depositional disruption and tectonic superposition of the Cretaceous sediment layers, probably because of large-scale gravity sliding. Evidence comes from (1) sedimentary structures, (2) the biostratigraphic record, (3) down-hole logs, and (4) seismic-reflection records.

1. In nearly all cores there is abundant evidence of shearing and small-scale folding, most of which took place while the sediments were still fairly plastic. In Cores $415 \mathrm{~A}-13$ and $415 \mathrm{~A}-14$, fracture patterns suggest more-brittle rocks, and in Core 415A-14 fractures are filled with calcite veins.

2. Age assignments for cores from this interval indicate anomalously high rates of accumulation. We do not have sure means of calculating such rates for the entire interval, but, as an example, the middle-Cretaceous sediments (Rotalipora cushmani Zone) have a minimum thickness of over 300 meters, indicating a minimum rate of accumulation of $200 \mathrm{~m} / \mathrm{m}$.y. during the corresponding period. Such figures do not seem appropriate for fine-grained mudstone deposited below the CCD in 3000 to 4000 meters of water.

3. The gamma-ray log for the interval between 491 and 753 meters shows striking patterns that suggest at least three and perhaps five repetitions of a single log signature (Figure 36 ). The log cycles thus defined are illustrated in Figure 37. The match of cycles 2 and 3 is particularly striking. Cycle 1 is incomplete, but may contain a repetition of the upper part of the characteristic log signature. Cycle 4 shows a good log correspondence with cycles 2 and 3 , although the match is not as good as that between cycles 2 and 3 . Another possible correlation of cycles is shown in Figure 38.

It is difficult to see how such exact repetition of the log signature could occur without at least a three-fold and perhaps a four- or five-fold lithologic repetition, of 


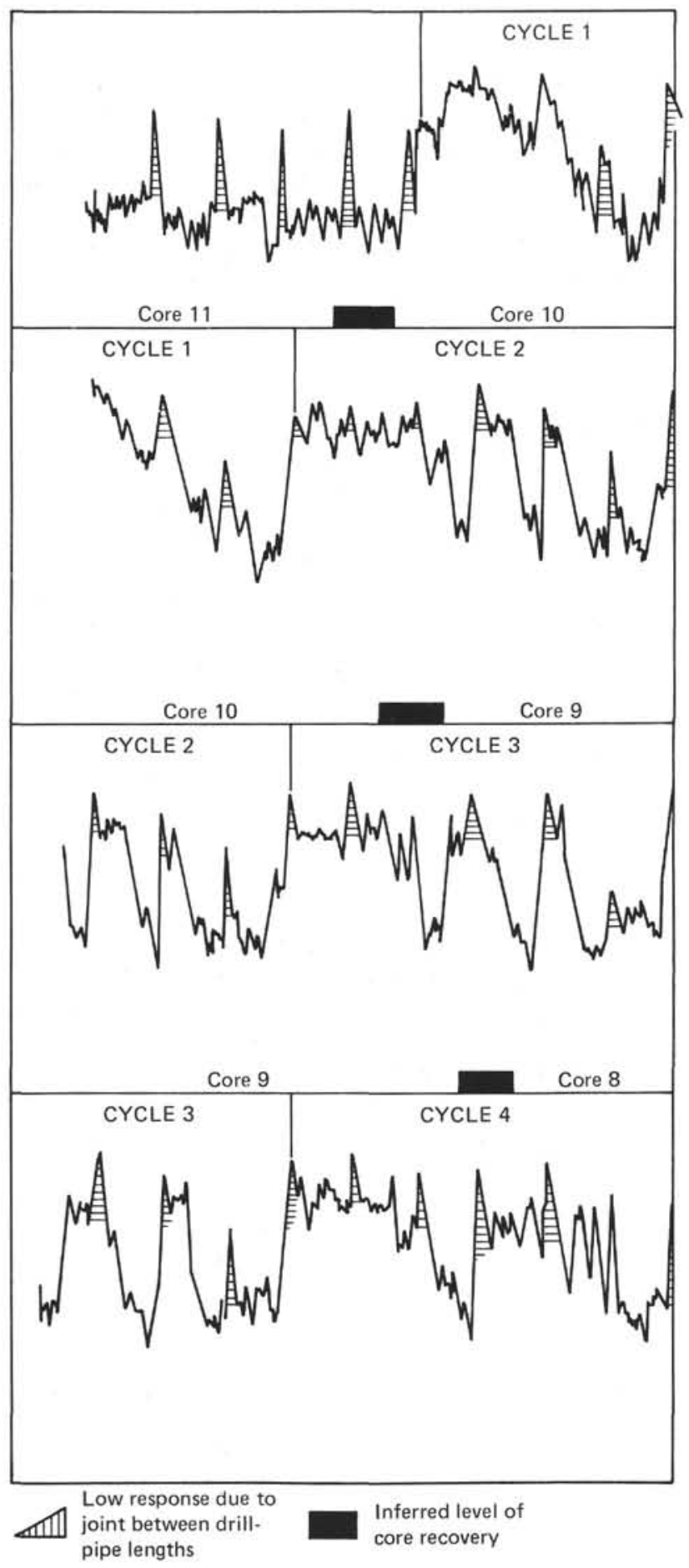

Figure 37. A possible correlation of cycles on the gamma-ray log, Hole $415 \mathrm{~A}$.

either sedimentary or tectonic origin. The basic sequence (cycles 2 and 3 ) is some 57 meters thick, carbonate-rich at the base and becoming more shaley upwards. The starting place in the cycles can be changed from the base to the top of the carbonate-rich part without loss of similarity among cycles. We suspect that the match of cycles 2 and 3 is too perfect to be a product of cyclic

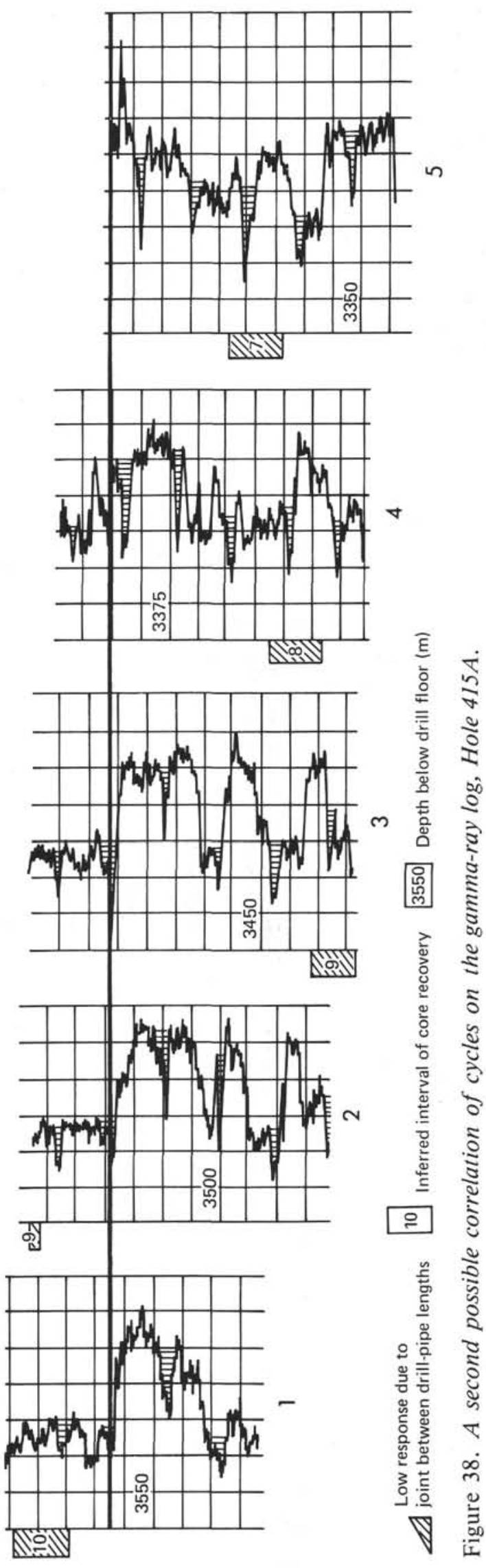


sedimentation and believe that the sequence has been stacked several times in a slump mass. (See Price, this volume, for regional implications).

4. On the seismic profiles, the interval of slide sheets apparently corresponds with the upper two-thirds of the section between the red and orange reflectors, an interval characterized by a general lack of coherent reflections; by slightly inclined, discontinuous reflectors; and by abundant small-scale diffractions. These acoustic characteristics confirm the overall impression that largescale displacement of sediment has taken place over considerable distances in the Moroccan Basin within a relatively restricted stratigraphic interval.

The evidence from Site 415 points to gravitational sliding under very modest overburden, rather than regional tectonism, as the mechanism of deformation. The style of deformation shows that the sediments were very plastic during displacement. Redeposited shelf and upper-slope materials in the beds suggest that the site of original accumulation was on or at the foot of the continental slope; the autochthonous foraminifers suggest 3000 to 4000 meters of water depth. A plausible origin is gravitational sliding of a relatively thin sheet of sediments - possibly 200 meters thick - bounded at its base by a contact between Albian shales and underlying, more competent rocks. During sliding, under this model, the sheet was riven by internal shears, especially at contacts between more- and less-competent layers, and the sub-sheets were plastically deformed.

\section{Cenozoic}

\section{Paleogene}

The Paleogene sediments at Site 415 are separated from middle to late Cretaceous strata by a major hiatus. This unconformity was not actually cored, and even though the core barrel placed in the drill string (Core 415A-6) was open for collecting samples from both above and below the unconformity, only Paleocene rocks were recovered. In that coring interval, the gamma-ray log shows a sharp peak in radioactivity of the sediments, corresponding to a local enrichment in radioactive material that is plausibly associated with an unconformity. For this reason the Cretaceous/Tertiary boundary has been placed at the level of this peak ( 491 $\mathrm{m}$ sub-bottom). It is of course tempting to associate this unconformity with the major red reflector observed on the seismic profiles of this area. The correlation is not straightforward, however, because our recovered sediment samples did not show a major change in acoustic properties between the Cretaceous and the Tertiary beds. It is thus possible that the reflector corresponds in fact to the lowermost Tertiary beds that were sampled some 25 meters above the level at which we have placed the hiatus. Indeed, the results from logging at Site 416 to the north clearly show that the red reflector there corresponds to a hiatus at the top of the Paleocene beds, and not to the Cretaceous/Tertiary boundary, which occurs some 20 meters below.

Seismic profiles recorded in the vicinity of the site (see Meteor 3902 profile in the chapter on underway geophysics, this volume) indicate that after the folding of the Cretaceous beds sediment-accumulation patterns resulted in a smoothing of the topography: synclines were accumulating more sediments than anticlines, conferring a more or less lenticular geometry to the strata between the red reflector and a reflector parallel to and about 0.1 to 0.15 seconds below the brown reflector (sub-brown reflector). It is therefore probable that the main deformation of the Cretaceous beds had already ended by Paleocene times, although minor slump features in Paleocene sediments might still be related to the late Cretaceous tectonics.

The Paleogene was very poorly sampled, and interpretations can be only very tentative. The age of the recovered sediments ranges from early Paleocene to early Eocene. The accumulation rate during this interval would have been about $15.5 \mathrm{~m} / \mathrm{m}$.y., although the wide gap between the Paleocene and Eocene samples makes this value extremely tentative. The Paleocene sediments consist of mudstones, with conspicuous intercalations of nannofossil chalk and limestone. Sediments of Paleocene age in the deep basins of the North Atlantic are very rare. Although they are present on elevated areas such as Sierra Leone Rise and Ceara Rise, they are generally missing in the deep basins, probably because of extensive erosion caused by vigorous bottom-water circulation. On the other hand, they have been sampled in deep water off Morocco at Site 370, but at that site the rate of accumulation shows a marked minimum in that interval, following a Cenomanian-Paleocene hiatus. Early-Paleocene sediments at both Site 370 and Site 415 contain relatively high proportions of carbonate, although during the early Paleocene there was a marked shoaling of the CCD in the North Atlantic (Berger and von Rad, 1972).

Although the higher rate of accumulation of carbonate sediments at Site 415 could result from regional uplift during the earliest Tertiary, which would have brought the sea floor to the "abnormal" level at which it lies today, above the level of the CCD, a non-tectonic effect, such as regional deepening of the CCD or downslope transport and redeposition of the calcareous material, could as well provide an explanation. Redeposition is especially well documented in this interval by the occurrence of a layer of Maestrichtian chalk within the Paleocene section. Actually, this layer contains the only evidence of Upper Cretaceous beds on the slopes east of Site 415. The low carbonate content of the overlying upper-Paleocene and lower-Eocene sediments also suggests that part or all of the Paleocene layers might be redeposited; furthermore, the sharp contacts both at the base and at the top of these layers suggest redeposition. Even the 3-m.y. hiatus that separates the lower from the upper Paleocene may be the result of redeposition.

Early-Eocene sediments were recovered only in a very short core $(19 \mathrm{~cm})$ made up mainly of pebbles of porcellanite and cherty sandstone with nannofossil marl and mudstone. This sample is so small and so isolated in the section that it cannot be treated as truly representative of the whole interval. The rounded pebbles suggest long transport; thus, they might mark the initiation of Aga- 
dir Canyon, but the layering on seismic records of this interval suggests that the lower part of the canyon at that time was only a broad valley.

\section{Neogene}

Neogene sediments are almost certainly separated from the Paleogene by another hiatus, which, like the unconformity at the Cretaceous/Tertiary boundary, was not directly observed in the cores. Instead, it is inferred from the rate-of-accumulation curves; thus, it might just as well be a very condensed section. The exact depth of this unconformity cannot be determined easily, because it does not leave a clear signature on the downhole logs, although a gradual change in character of the gamma-ray signal is observed around 313 meters, becoming more pronounced around 330 meters. In fact, the condensed or missing interval may lie anywhere between the base of Core 415-5 (283 meters) and the top of Core 415A-1 (349 meters). A simple extrapolation of the rates of accumulation for strata below and above this interval shows that the hiatus could span a time period of about 29 m.y., encompassing part of the lower Miocene, the entire Oligocene, the entire upper Eocene, and - depending on the level at which one chooses to place the unconformity - either the entire middle Eocene and the uppermost part of the lower Eocene, or only part of the middle Eocene (see Figure 33).

Alternatively, the section may be present in its entirety, but highly condensed, with an average rate of accumulation of only about $2 \mathrm{~m} / \mathrm{m}$.y. In any case, the occurrence of a hiatus around the Eocene/Oligocene boundary is plausible in view of the wide extent of an unconformity at about that level in the eastern North Atlantic (Berger and von Rad, 1972; Lancelot and Seibold, 1978; Arthur et al., in press). Although the time-span of the hiatus is too large, and data too scarce, to specify the timing of the paleoceanographic event responsible for the unconformity, it is tempting to relate it to the onset of vigorous bottom-water circulation associated with the first strong influx of Antarctic bottom water in the basin. However, it might also result from local paleoenvironmental conditions associated with the evolution of the adjacent margin.

The Neogene sediments consist mainly of marls and chalks to oozes, with relatively abundant siliceous microfossils in the lower part of this interval. They accumulated at the high rate of 18 to $20 \mathrm{~m} / \mathrm{m}$.y., with a temporary decrease during the late middle Miocene and late Miocene, when the rate dropped to an average of 9 $\mathrm{m} / \mathrm{m}$.y. Another brief but marked decrease (or possibly a short hiatus) appears at the Miocene/Pliocene boundary. It is associated with a notable deterioration in the preservation of planktonic foraminifers and therefore could be caused by a momentary shoaling of the CCD related to the "salinity crisis" in the Mediterranean Sea. The increase in the rate of accumulation during the Neogene relative to the rates derived for the underlying sediments might also be explained by the increase in carbonate contribution caused by the uplift of the area near Site 415 at the time of uplift of the Canary Islands. It might also be caused in part by an increase in productiv- ity of the surface waters, as evidenced by the abundance of siliceous microfossils in the lower-Miocene sediments. Our cores are simply too widely spaced to allow us to choose among these possibilities.

\section{Geochemical Characteristics of the Section}

The Cretaceous sediments of the section contain about 1 per cent organic carbon, whereas in the Cenozoic the average is a little less than half that amount. Gas-analysis data show a clear trend toward higher concentrations of heavier compounds with depth, and pyrolysis data show a parallel trend toward greater values of the index of generated hydrocarbons with increasing depth. Most of the organic matter appears to be detrital and shows rather poor hydrocarbon-generation properties. (For more detailed analyses and interpretations, see various chapters on organic geochemistry in this volume.)

Analyses of pore waters from the rocks show a striking maximum in chlorinity and salinity at about 500 meters sub-bottom. This maximum may result from an interstratal influx of brines flowing from the large evaporite field that lies less than $50 \mathrm{~km}$ east of the site. Such an influx may also explain the occurrence of sepiolite and palygorskite (attapulgite) in this interval. On the other hand, these minerals may be detrital, because they are common in the lower-Tertiary sediments of several basins bordering Northwest Africa. (See Gieskes et al., this volume, for discussion of the various down-hole geochemical trends.)

\section{REFERENCES}

Archie, G. E., 1942. The electrical resistivity log as an aid in determining some reservoir characterisics, Trans. AIME, v. 146, p. 54 .

Arthur, M. A., von Rad, U., Cornford, C., McCoy, F., and Sarnthein, M., 1979. Evolution and sedimentary history of the Cape Bojador continental margin, northwestern Africa. In Ryan, W., von Rad, U., et al., Initial Reports of the Deep Sea Drilling Project, v. 47, Part 1: Washington (U. S. Govt. Printing Office), p. 773.

Berger, W. and von Rad, U., 1972. Cretaceous and Cenozoic sediments from the Atlantic Ocean. In Hayes, D. E., Pimm, A. C., et al., Initial Reports of the Deep Sea Drilling Project, v. 14: Washington (U. S. Govt. Printing Office), p. 787-954.

Berggren, W. A., 1973. The Pliocene time-scale: calibration of planktonic foraminiferal and calcareous nannoplankton zones, Nature, v. 243, p. 391-397.

Boyce, R. E., 1968. Electrical resistivity of modern marine sediment from the Bering Sea, J. Geophys. Res., v. 73, p. 4759 .

1976. Sound velocity-density parameters of sediment and rock from DSDP drill Sites $315-318$ on the Line Islands Chain, Manihiki Plateau and Tuamotu Ridge in the Pacific Ocean. In Schlanger, S. O., Jackson, E. D. et al., Initial Reports of the Deep Sea Drilling Project, v. 33: Washington (U. S. Govt. Printing Office), p. 695.

Cita, M. B., 1975, Studi sul Pliocene e sugli strati di passagio dal Miocene al Pliocene. VIII. Planktonic foraminiferal biozonation of the Mediterranean Pliocene deep sea record, a revision, Riv. Ital. Paleont., v. 81, p. 527-544. 
Cita, M. B. and S. Gartner, 1973. The stratotype Zanclean. Foraminiferal and nannofossil biostratigraphy, Riv. It. Paleont. Strat., v. 79, p. 503-558.

Gartner, Jr., S., 1973. Absolute chronology of the late Neogene nannofossil succession in the equatorial Pacific, Geol. Soc. Am. Bull., v. 84, p. 2021-2034.

Hamilton, E. L., 1959. Thickness and consolidation of deep sea sediments, Geol. Soc. Am. Bull., v. 70, p. 1399. 1964. Consolidation characteristics and related properties of sediments from experimental Mohole (Guadalupe Site), J. Geophys. Res., v. 69, p. 4257. 1965. Sound speed and related physical properties of sediments from experimental Mohole (Guadalupe Site), Geophysics, v. 30, p. 257. 1976. Variations of density and porosity with depth in deep-sea sediments, J. Sed. Petrol., v. 46, p. 280.

Hays, H. D., Saito, T., Opdyke, N.D. and Burckle, L. H., 1969. Pliocene-Pleistocene sediments of the equatorial Pacific-their paleomagnetic, biostratigraphic and climatic record, Geol. Soc. Am. Bull, v. 80, p. 1481-1514.

Hollister, C., Ewing, J., et al., 1972. Initial Reports of the Deep Sea Drilling Project, v. 11: Washington (U. S. Govt. Printing Office).

Kennett, J. P. and Watkins, N. D., 1974. Late Miocene-Early Pliocene paleomagnetic stratigraphy, paleoclimatology and biostratigraphy in New Zealand, Geol. Soc. Am. Bull., v. 85 , p. $1385-1398$.

Lancelot, Y. and Seibold, E., 1978. The evolution of the Central Northeastern Atlantic-summary of results of DSDP Leg 41. In Lancelot, Y., Seibold, E., et al., Initial Reports of the Deep Sea Drilling Project, v. 41: Washington (U. S. Govt. Printing Office), p. 1215-1245.

Lancelot, Y., Seibold, E., et al., 1978. Initial Reports of the Deep Sea Drilling Project, v. 41: Washington (U. S. Govt. Printing Office).

Lee, H. J., 1973. Measurements and estimates of engineering and other physical properties, Leg. 19. In Creager, J. S., Scholl, D. W., et al., 1973. Initial Reports of the Deep Sea Drilling Project, v. 19: Wasnington (U. S. Govt. Printing Office), p. 701-720.
Lynch, E. J., 1962. Formation Evaluation. New York (Harper \& Row)

Ryan, W. B. F., Cita, M. B., Dreyfus, R. M., Burckle, L. H., and Saito, T., 1975. A paleomagnetic assignment of Neogene stage boundaries and the development of isochronous datum planes between the Mediterranean, the Pacific and Indian Oceans in order to investigate the response of the World Ocean to the Mediterranean "Salinity Crisis", Riv. It. Paleont. Strat., v. 80, p. 631-688.

Saito, T., Burckle, L. M. and Hays, J. D., 1975. Late Neogene Epoch boundaries in deep sea sediments. In Symposium on Late Neogene Epoch Boundaries: Internat. Geol. Congr., Montreal, Micropaleontology Press, Special Publ. No. 1, p. 226-244.

Schlumberger, 1972. Log interpretations. Volume 1: Principles: New York (Schlumberger Ltd.).

Sliter, W. V., 1976. Cretaceous foraminifers from the southwestern Atlantic Ocean, Leg 36, Deep Sea Drilling Project. In Barker, P., Dalziel, I. W. D., et al., Initial Reports of the Deep Sea Drilling Project, v. 36: Washington (U. S. Govt. Printing Office), p. 519-573.

1977. Cretaceous benthic foraminifers from the western South Atlantic, Leg 39, Deep Sea Drilling Project. In Supko, P. R., Perch-Nielsen, K., et al., Initial Reports of the Deep Sea Drilling Project, v. 39: Washington (U. S. Govt. Printing Office), p. 657-697.

Thomas, B. D., Thompson, T. G., and Utterback, C. L., 1934. The electrical conductivity of sea water, J. Conseil., Conseil Perm. International Exploration Mer, v. 9, p. 28.

Tittman, J. and Wahl, J. S., 1965. The physical foundations of formation density logging (gamma-gamma), Geophysics, v. 30, p. 284.

Trabant, P. K., 1978. Synthesis of physical properties data from DSDP Leg 41. In Lancelot, Y., Seibold, E., et al., Initial Reports of the Deep Sea Drilling Project, v. 41: Washington (U. S. Govt. Printing Office), p. 1199-1214.

Winsauer, W. O., Shearing, H. M. Jr., Mason, P. H., and Williams, M., 1952. Resistivity of brine-saturated sands in relation to pore geometry, Bull. Am. Assoc. Petrol. Geol., v. 36, p. 253 . 


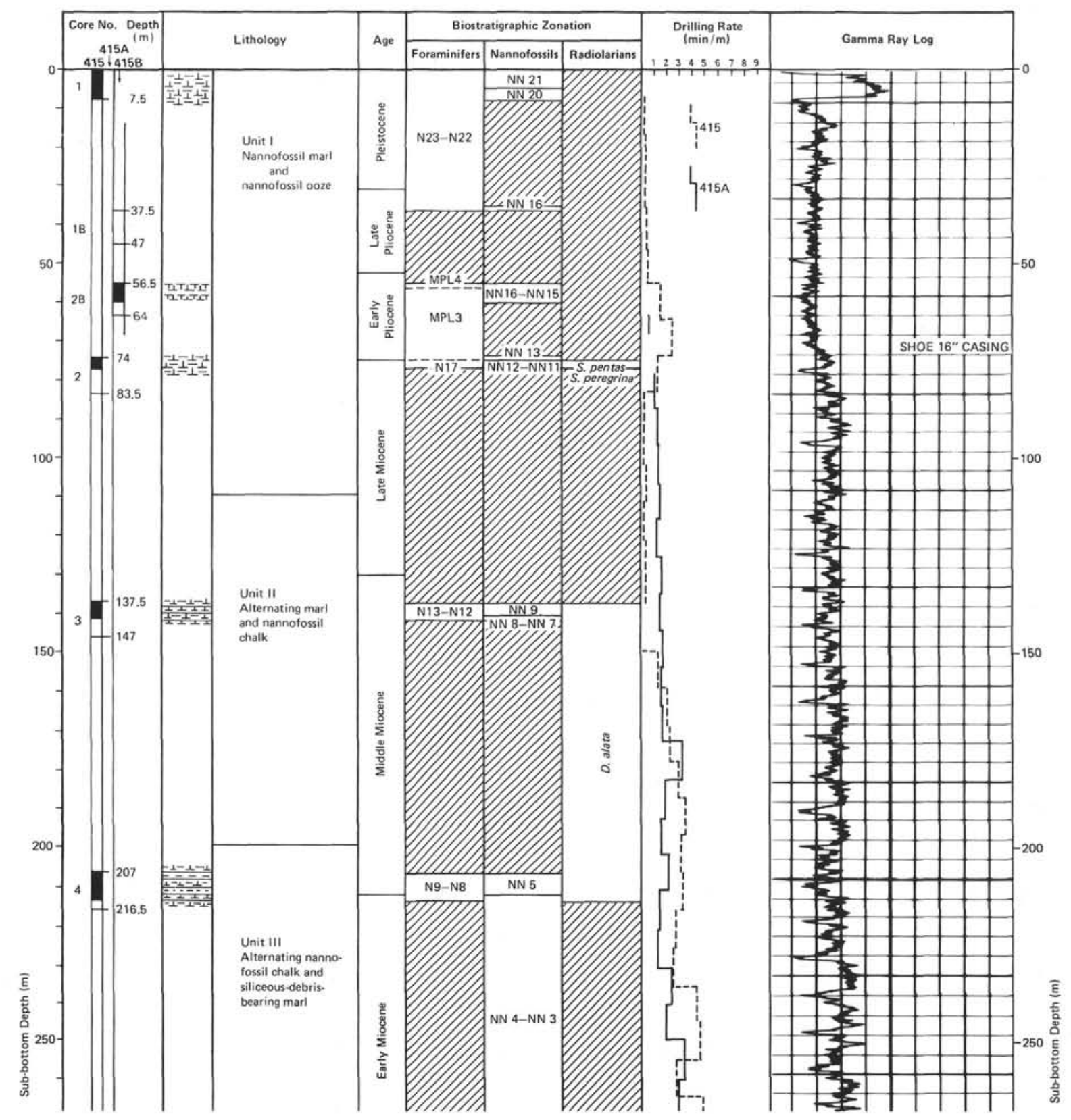



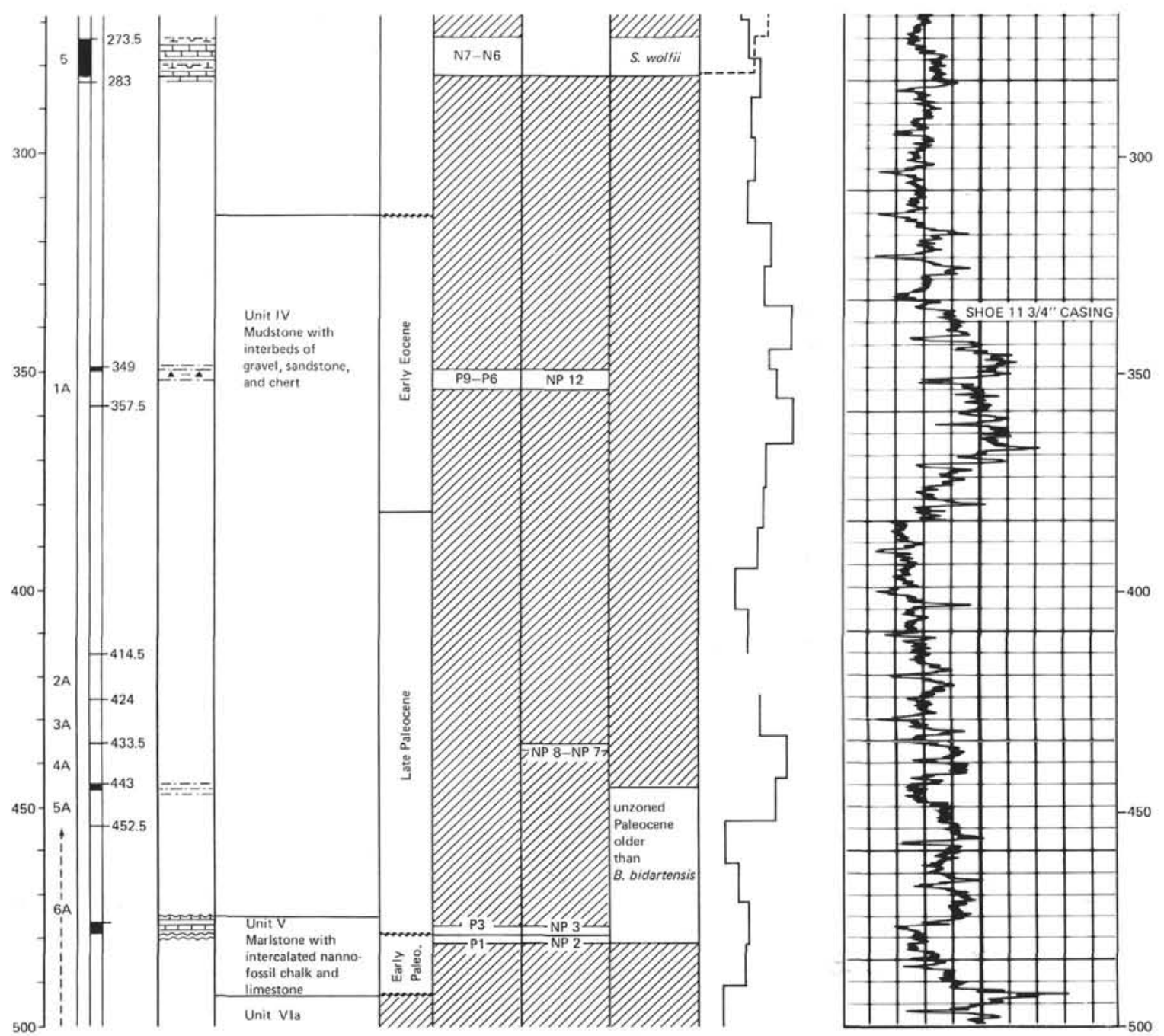

Figure 8. Graphic site summary. The gamma-ray log of Hole $415 \mathrm{~A}$ was measured through the drill string, cone, and casing. (See text discussion of artifacts created by drill string, cone, and two sets of casing.) Approximate depth below sea floor equals well log depth minus 10 meters, minus water depth (2807 meters). 


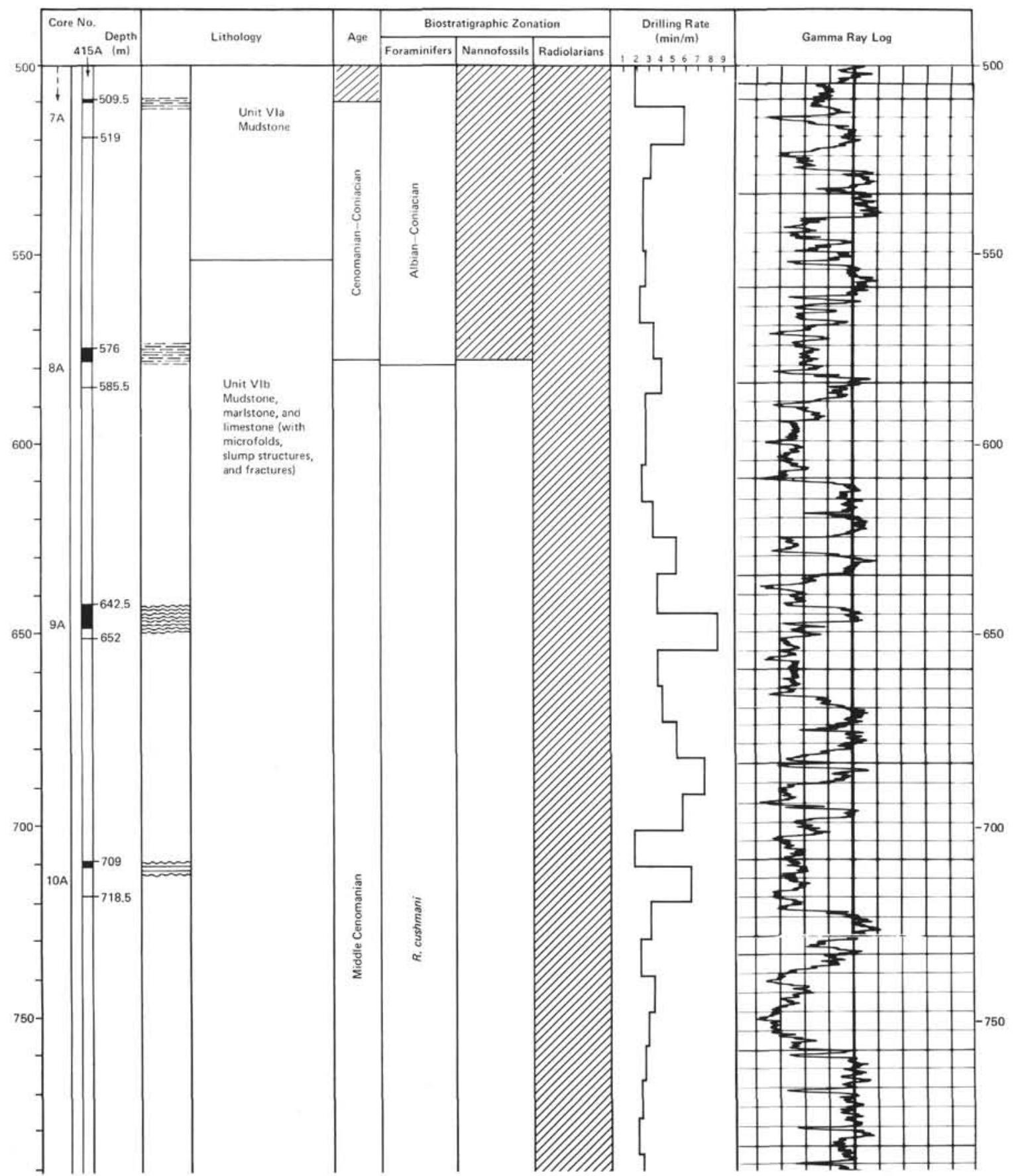




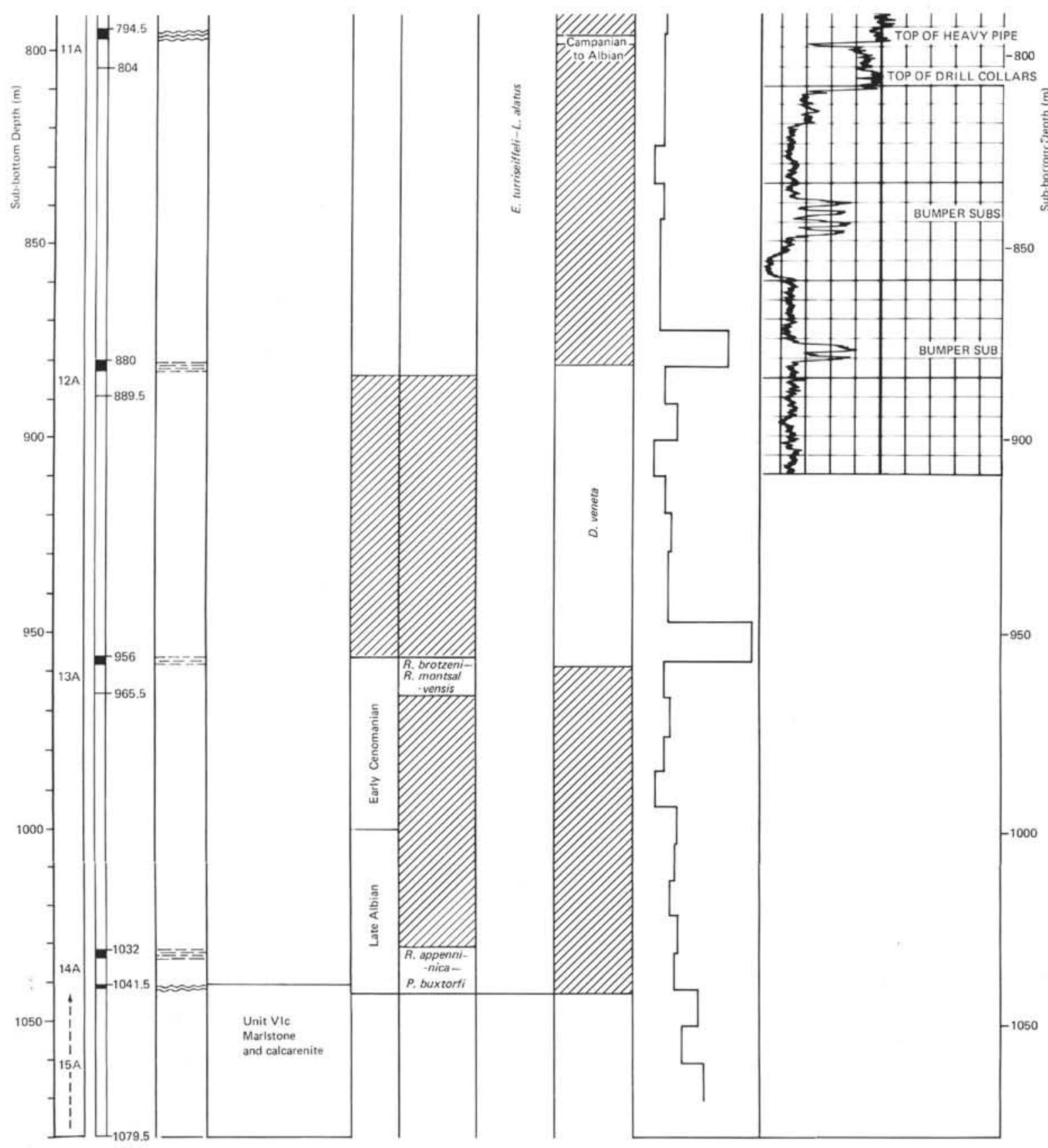


SMEAR SLIDE SUMMARY - SITE 415
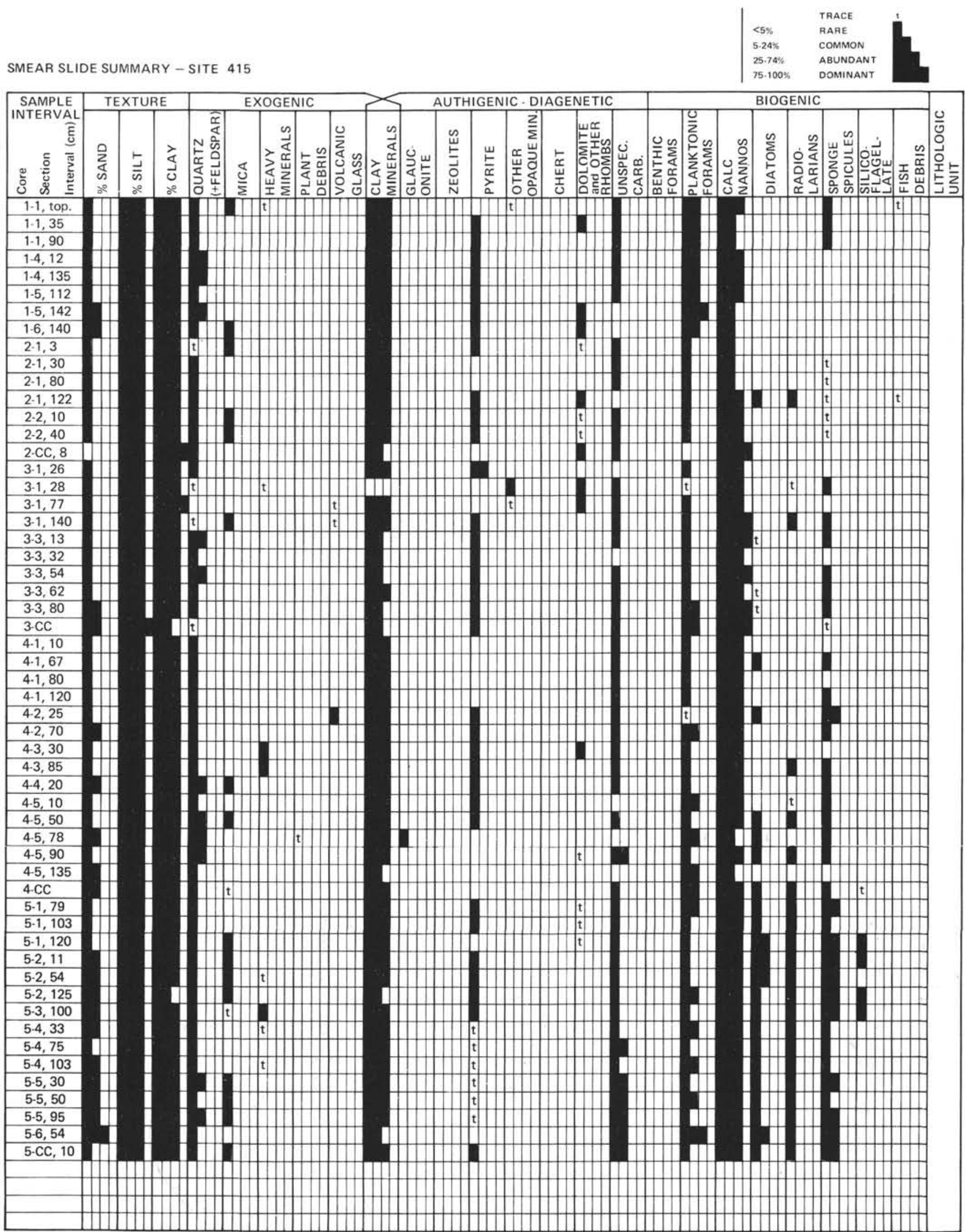

Figure 9. Visual estimates of sediment composition from smear slides at Site 415. A. Hole 415. B. Hole 415A. C. Hole $415 B$. 


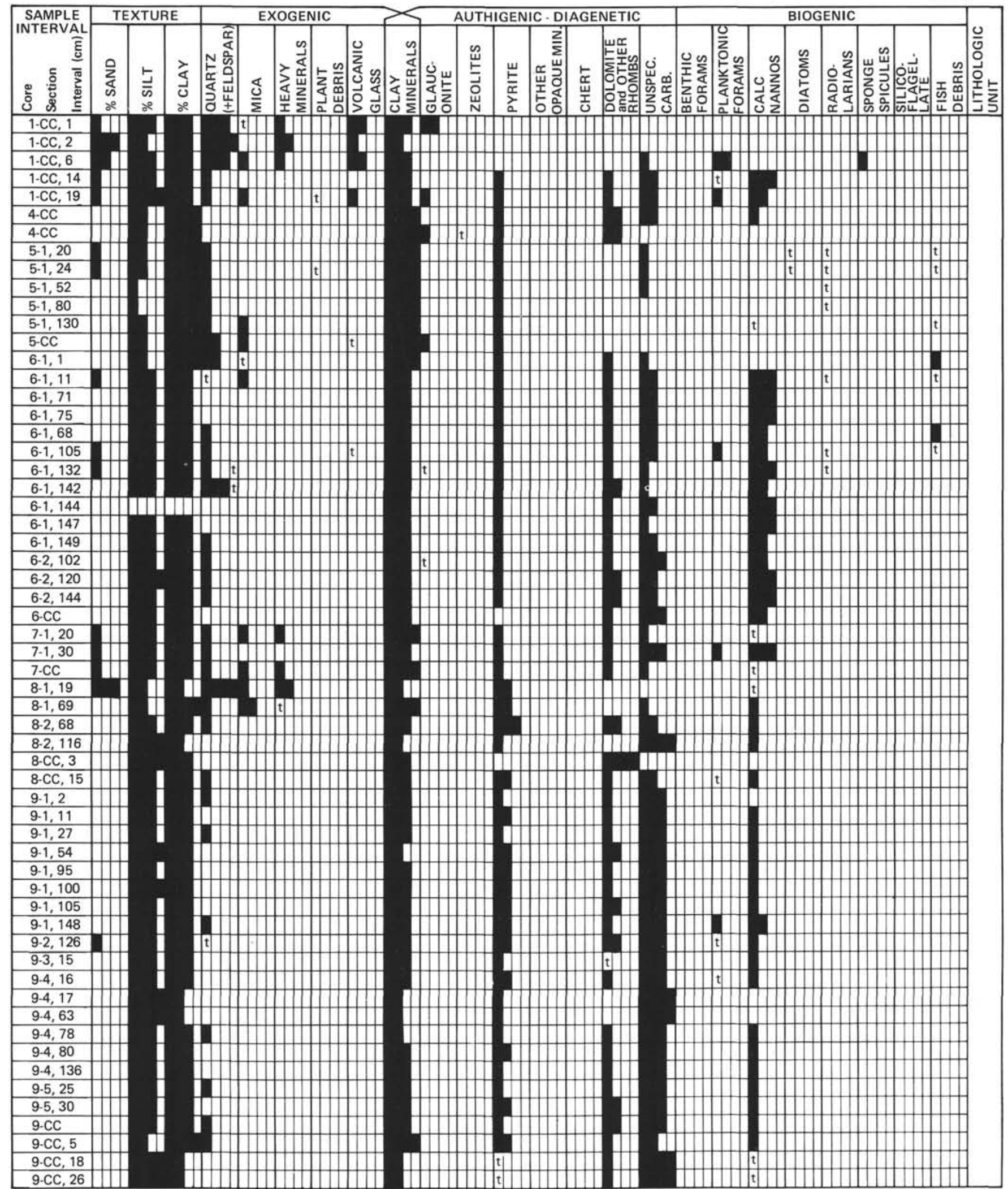

Figure 9. Continued. 
SMEAR SLIDE SUMMARY - Hole 415A

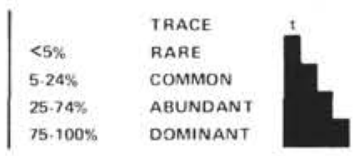

\begin{tabular}{|c|c|c|c|c|c|c|c|c|c|c|c|c|c|c|c|c|c|c|c|c|c|c|c|c|c|c|}
\hline \multirow[b]{2}{*}{ 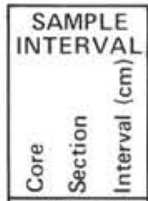 } & \multicolumn{3}{|c|}{ TEXTURE } & \multicolumn{5}{|c|}{ EXOGENIC } & \multicolumn{8}{|c|}{ AUTHIGENIC - DIAGENETIC } & \multicolumn{9}{|c|}{ BIOGENIC } & \multirow[b]{2}{*}{ 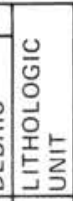 } \\
\hline & 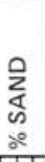 & $\begin{array}{l}\stackrel{5}{5} \\
\text { के }\end{array}$ & $\begin{array}{l}2 \\
0 \\
0 \\
0\end{array}$ & 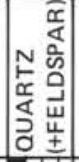 & $\frac{\mathbb{U}}{\Sigma}$ & 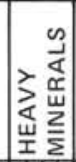 & 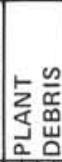 & 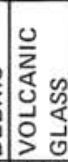 & 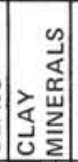 & نِ & 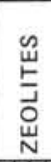 & $\frac{\vec{b}}{\frac{w}{\alpha}}$ & 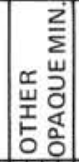 & 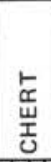 & 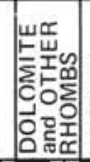 & 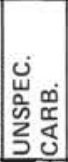 & 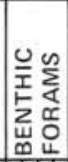 & 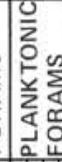 & & 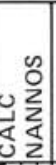 & $\begin{array}{l}\sum_{0}^{\infty} \\
\frac{1}{L} \\
\frac{4}{0}\end{array}$ & 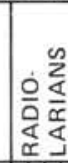 & 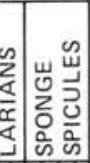 & 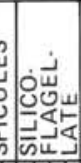 & 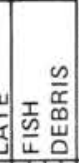 & \\
\hline $10-1,18$ & & & & & & & & & & & & & & & & & & & & & & & & & & \\
\hline $10-1,19$ & & & & & & & & & & & & & & & & & & & & & & & & & & \\
\hline $10-1,49$ & & & & & & & & & & & & & & & & & & & & & & & & & & \\
\hline $10-1,50$ & & & & & & & & & & & & & & & & & & & & & & & & & & \\
\hline $10-1,60$ & & & & & & & & & & & & & & & & & & & & & & & & & & \\
\hline $10-1,64$ & & & & & & & & & & & & & & & & & & & & & & & & & & \\
\hline $10-1,65$ & & & & & & & & & & & & & & & & & & & & & & & & & & \\
\hline $10-1,97$ & & & & & & & & & & & & & & & & & & & & & & & & & & \\
\hline $10-1,98$ & & & & & & & & & & & & & & & & & & & & & & & & & & \\
\hline $10-1,99$ & & & & & & & & & & & & & & & & & & & & & & & & & & \\
\hline $10-1,103$ & & & & & & & & & & & & & & & & & & $t$ & & & & & & & & \\
\hline $10 \cdot \mathrm{CC}$ & & & & & & & & & & & & & & & & & & & & & & & & & & \\
\hline $11-1,10$ & & & & & & & & & & & & & & & & & & & & & & & & & & \\
\hline $11-1,45$ & & & & & & & & & & & & & & & & & & & & & & & & & & \\
\hline $11-2,20$ & & & & & & & & & & & & & & & & & & & & & & & & & & \\
\hline $11 \cdot 2,70$ & & & & & & & & & & & & & & & & & & & & & & & & & & \\
\hline 11-CC, 13 & & & & & & & & & & & & & & & & & & & & & & & & & & \\
\hline $11 \cdot \mathrm{CC}, 20$ & & & & & & & & & & & & & & & & & & & & & & & & & & \\
\hline $12 \cdot 1,10$ & & & & & & & & & & & & & & & & & & $t$ & & & & & & & & \\
\hline $12-2,102$ & & & & & & & & & & & & & & & & & & & & & & & & & & \\
\hline $13-1,68$ & & & & & & & & & & & & & & & & & & & & & & & & & & \\
\hline $13-1,90$ & & & & & & & & & & & & & & & & & & & & & & & & & & \\
\hline $13-1,97$ & & & & & & & & & & & & & & & & & & & & & & & & & & \\
\hline $13-1,125$ & & & & & & & & & & & & & & & & & & & & & & & & & & \\
\hline $13-1,130$ & & & & & & & & & & & & & & & & & & & & & & & & & & \\
\hline $13-1,138$ & & & & & & & & & & & & & & & & & & & & & & & & & & \\
\hline $14-1,40$ & & & & & & & & & & & & & & & & & & & & & & & & & & \\
\hline $14-1,60$ & & & & & & & & & & & & & & & & & & & & & & & & & & \\
\hline 14-CC & & & & & & & & & & & & & & & & & & & & & & & & & & \\
\hline
\end{tabular}

SMEAR SLIDE SUMMARY - HOLE 415B
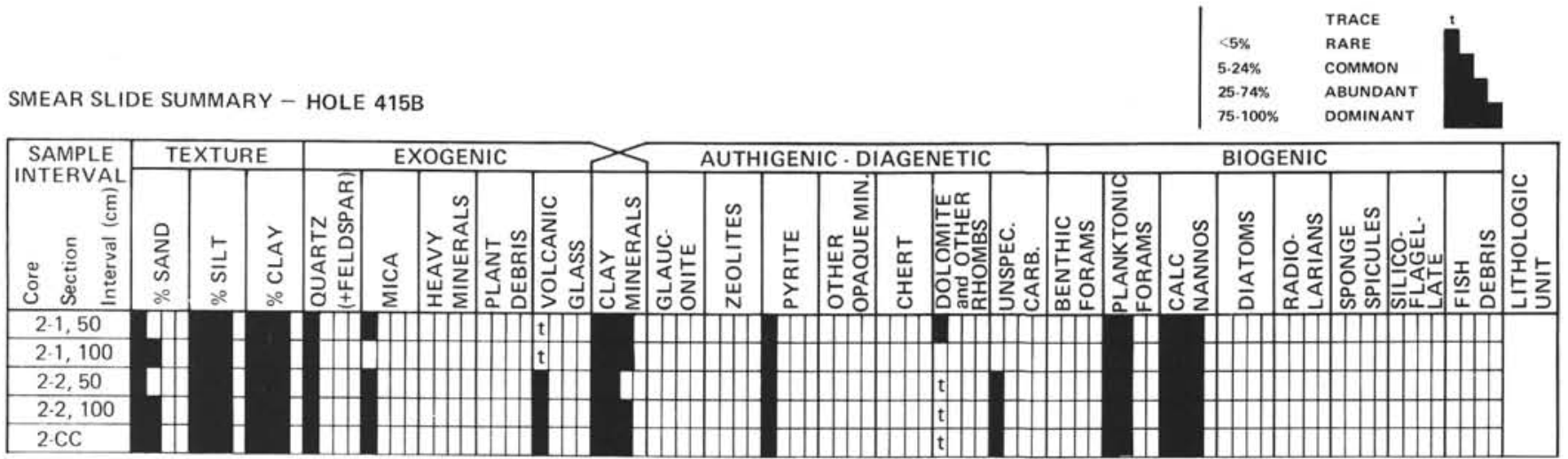

Figure 9. Continued. 
PHYSICAL PROPERTIES CORE PLOTS
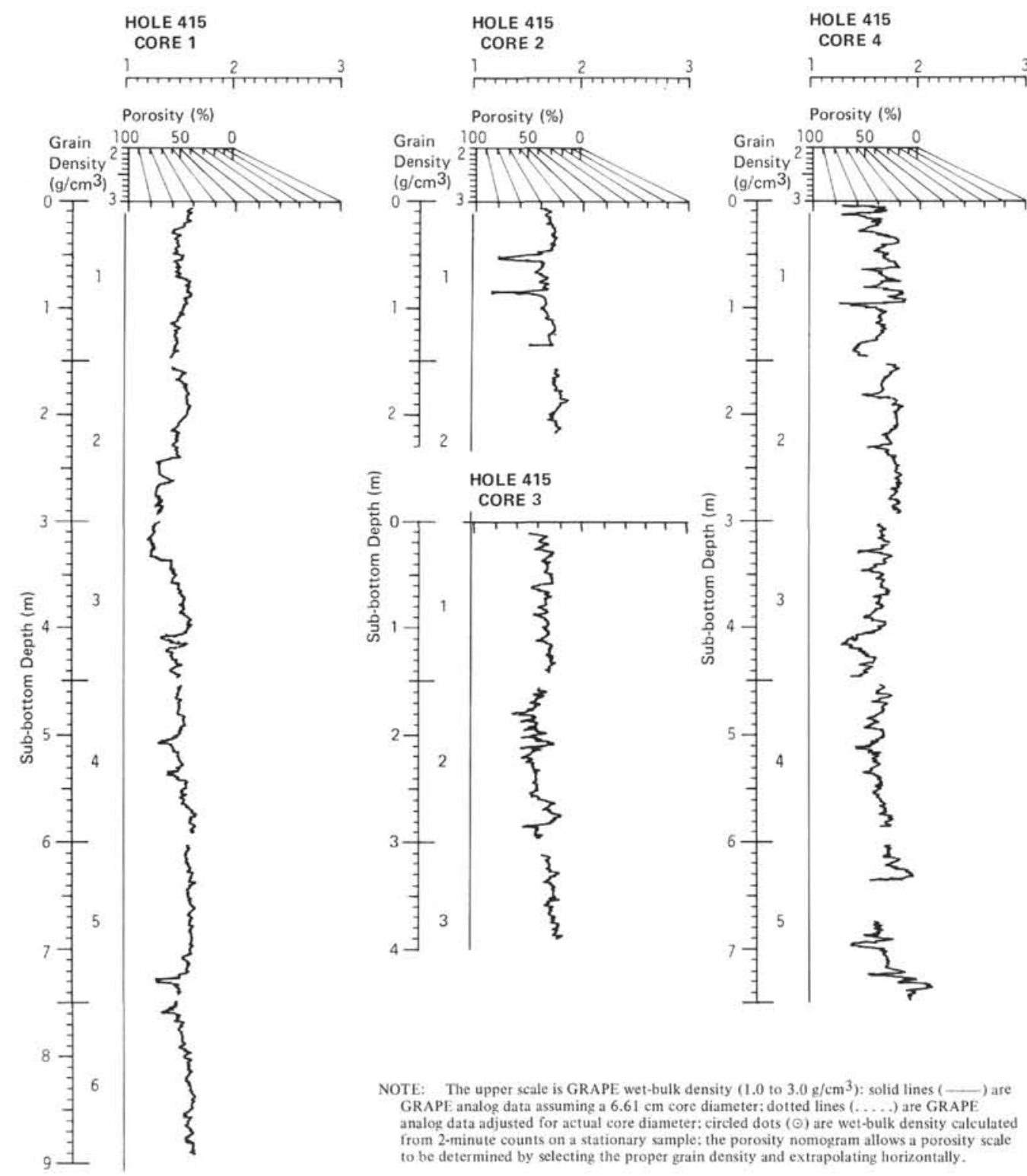

All Leg 50 GRAPE analog computer data has been severely edited for publication. For Leg 50 analog GRAPE data (particularly Site 416), all rock diameters were measured by hand, usually one measurement per $5 \mathrm{~cm}$ core segment. These core segments are very rough and ifregular, therefore, when these diameters land assumption of off set from the GRAPE beam as described by Equ the 36 in Boyce, 1976 are applied to the raw Cularly when small, irregular diameter core segments are scanied and the calculat (Equation 38) offeet is incorrect, thus cousing extremely bed data. As a result, the unadiusted GRAPE data are plotted as a solid line, with "diameter adiusted" date presented as a dotted line. The obvious errors were then corrected by hand This presentation allows investigators to manipulate the dato Investigators interested in the density of a specific layer or rock piece should check the sample diameter from the core photographs and make the appropriate diameter corrections, as discussed in Boyce (1976):

Boyce, R.E., 1976. Definitions and laboratory techniques of compressional sound velocity parameters and wet-water content, wet-bulk density, and porosity parameters by gravimetric and gamma ray attenuation techniques. In Schlanger, S.O., Jackson, E.D., et al.. Initial Reports of the Deep Sea Drilling Project, v. 33: Washington
(U.S. Government Printing Office), pp. 931-963. 


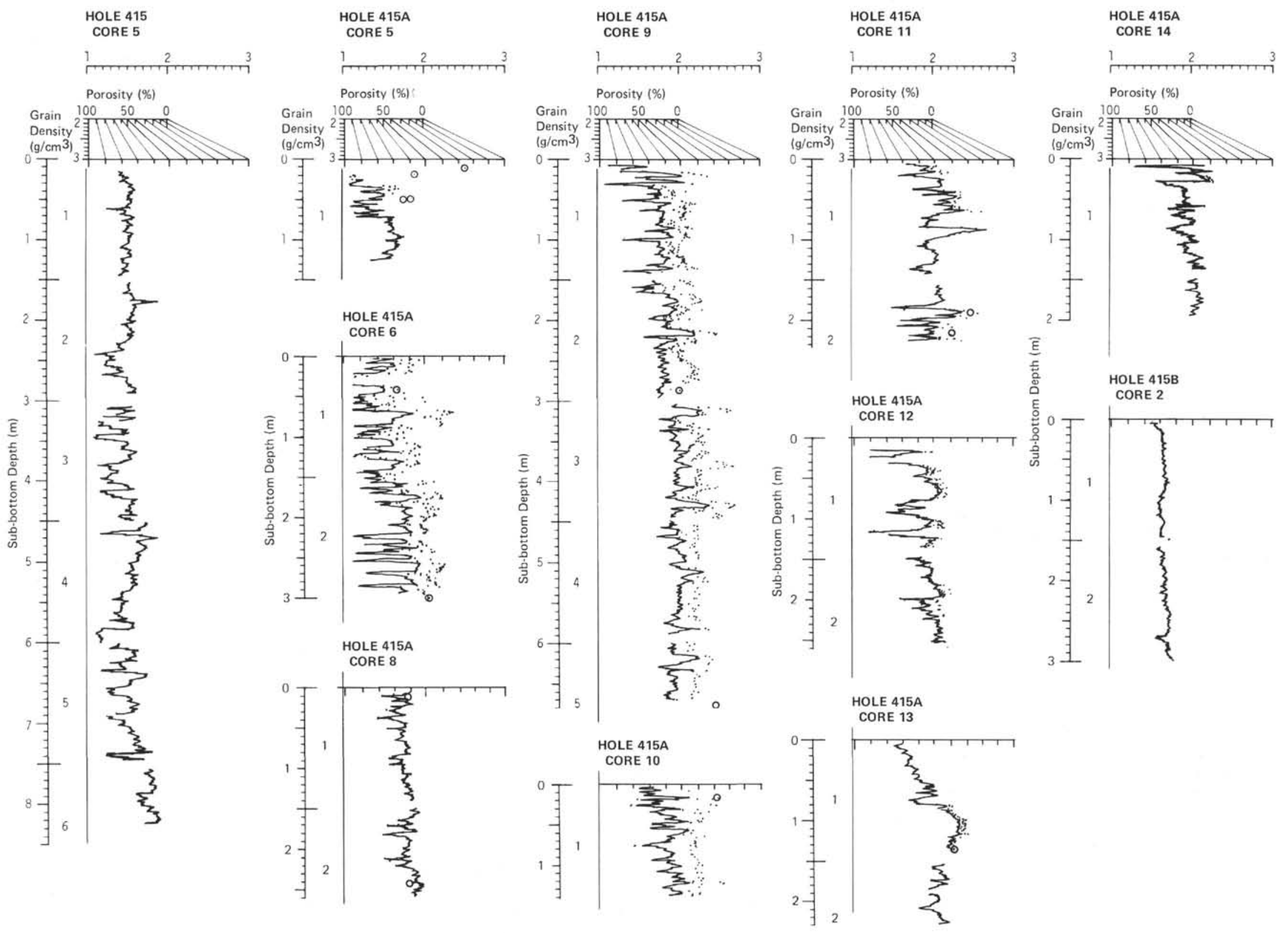


CORE DESCRIPTIONS, SITE $415^{1}$

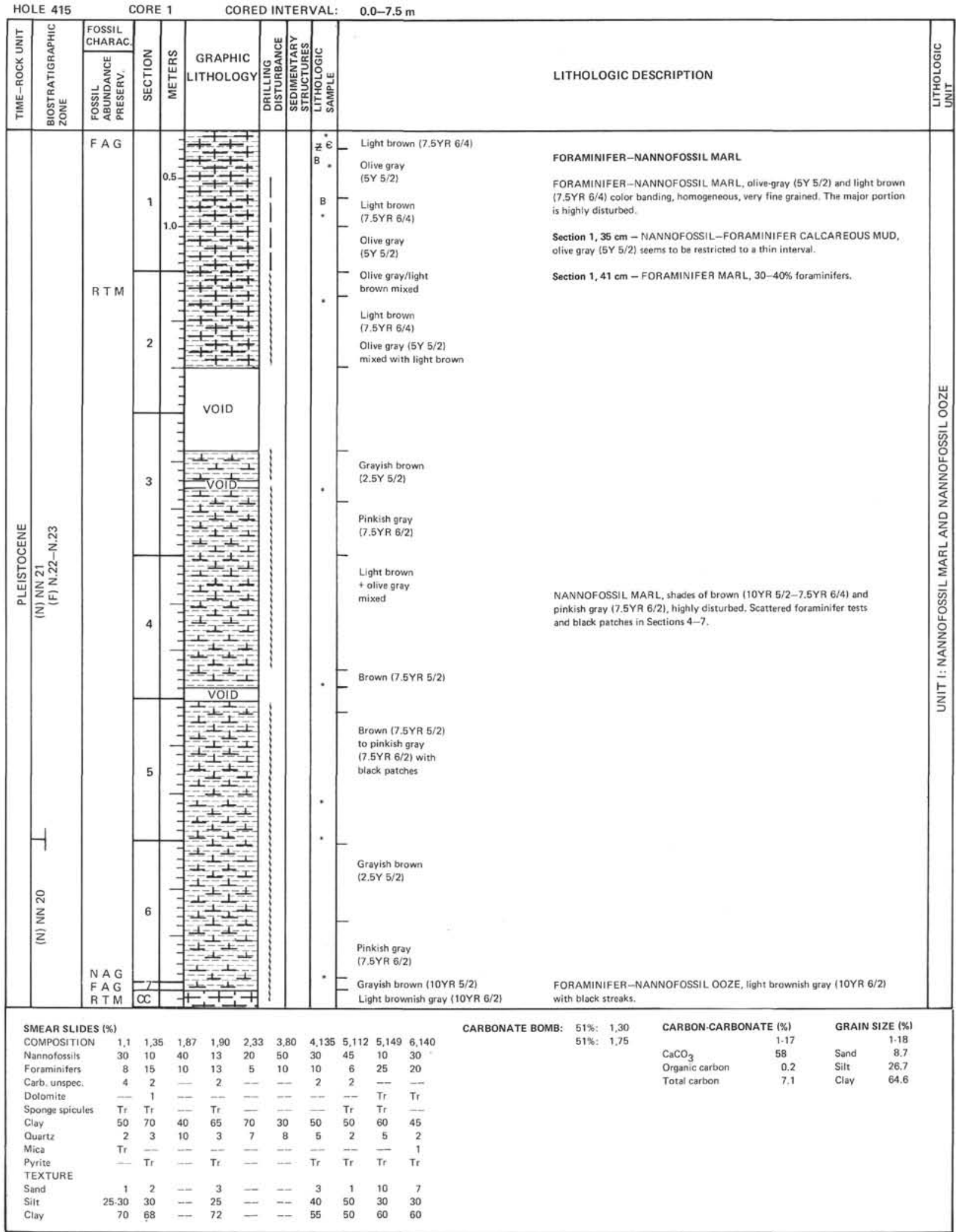

1 Information on core description sheets represents field notes taken aboard ship under time pressure. Some of this information has been refined in accord with postcruise findings, but production schedules prohibit definitive correlation of these sheets with subsequent findings. Thus the reader should be alerted to the occasional ambiguity or discrepancy. 
Site 415

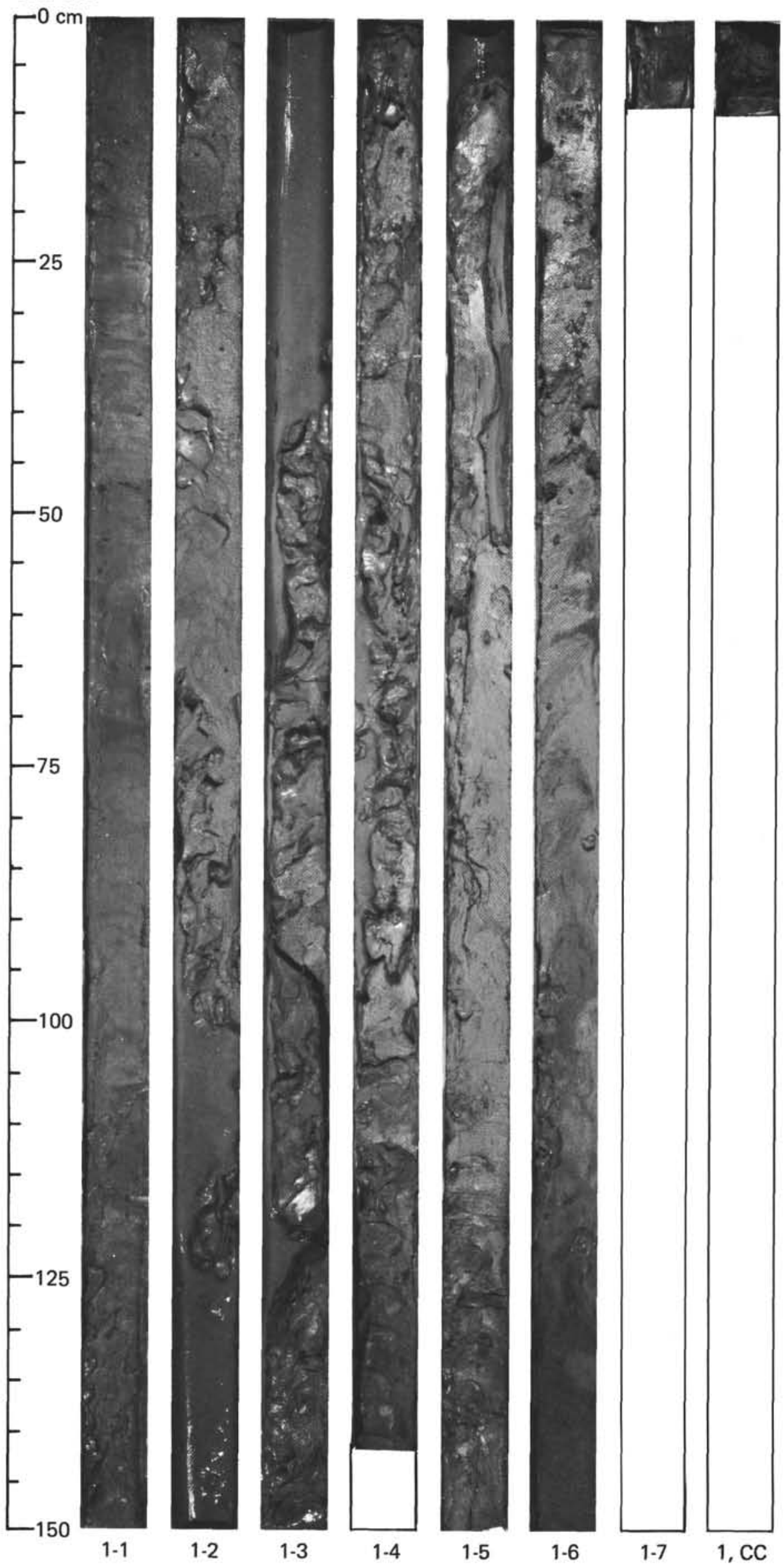




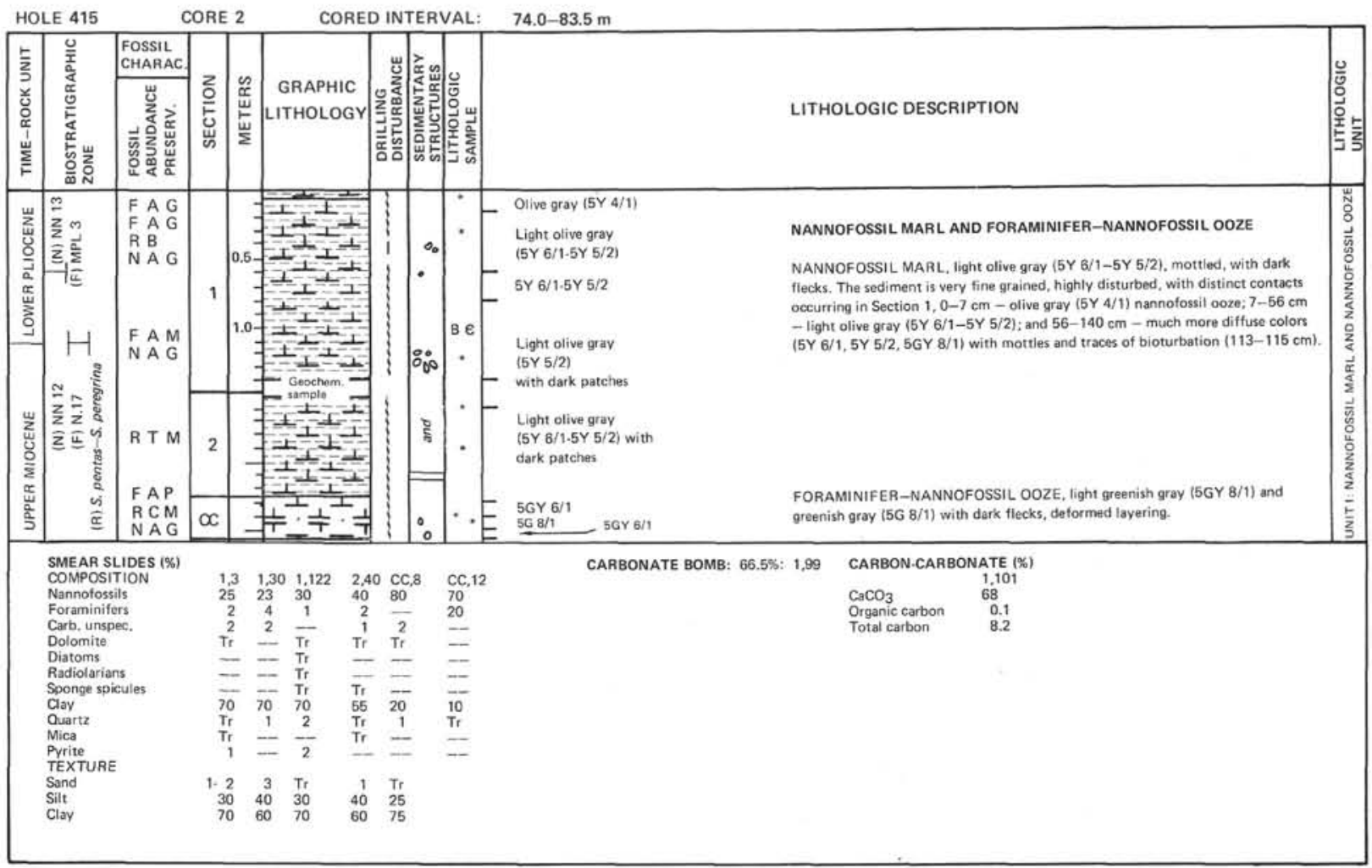

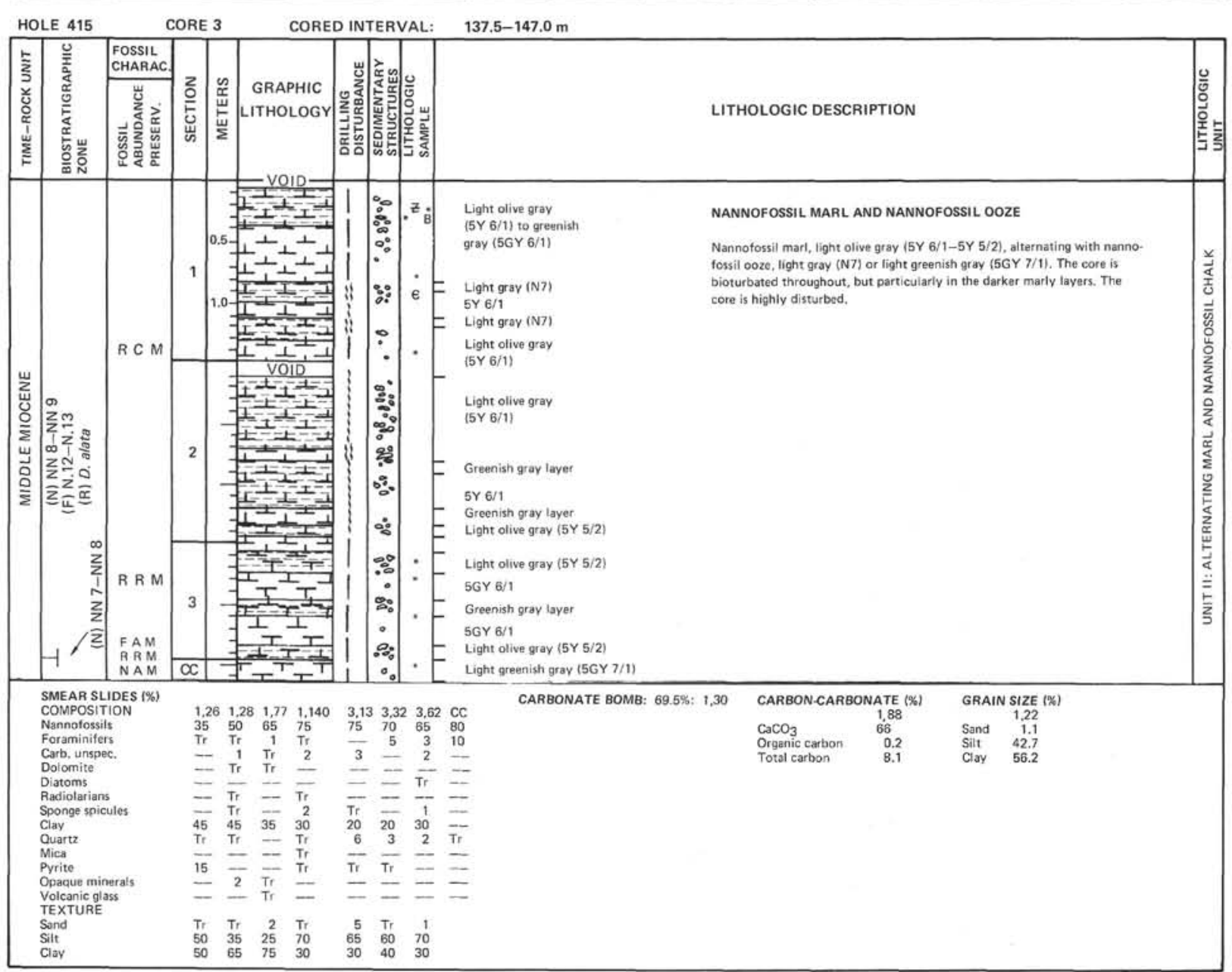


Site 415

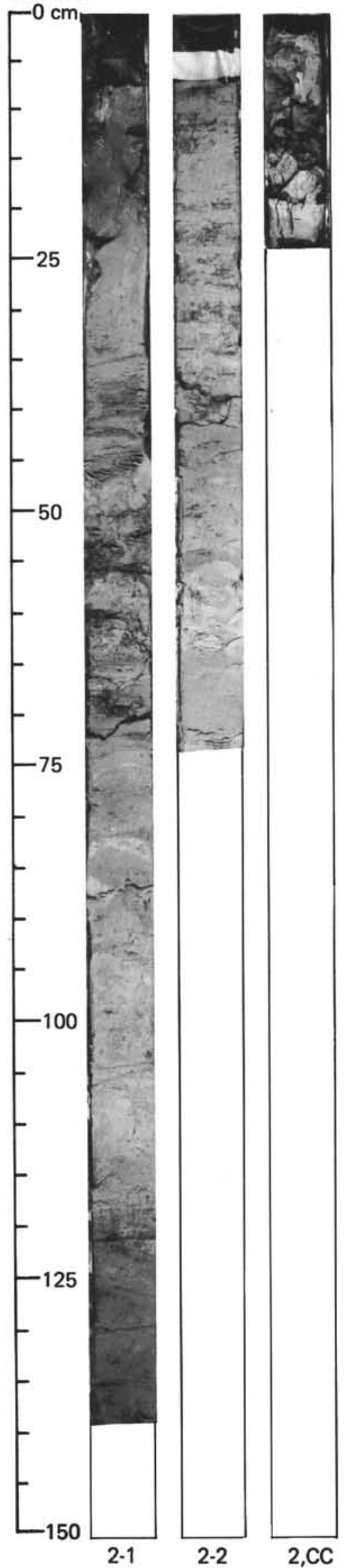

Site 415

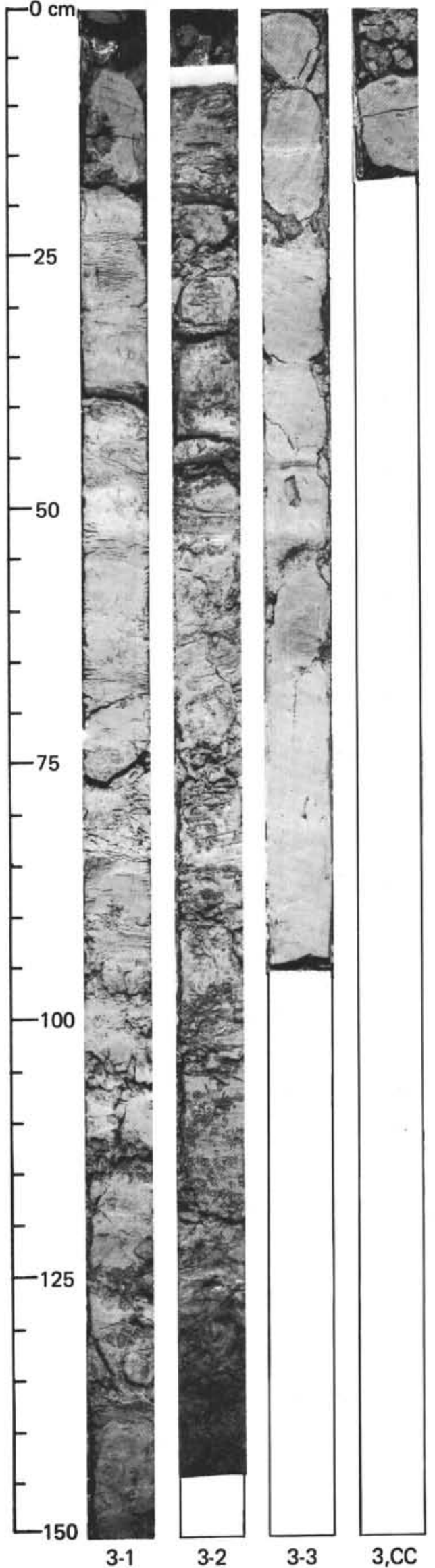




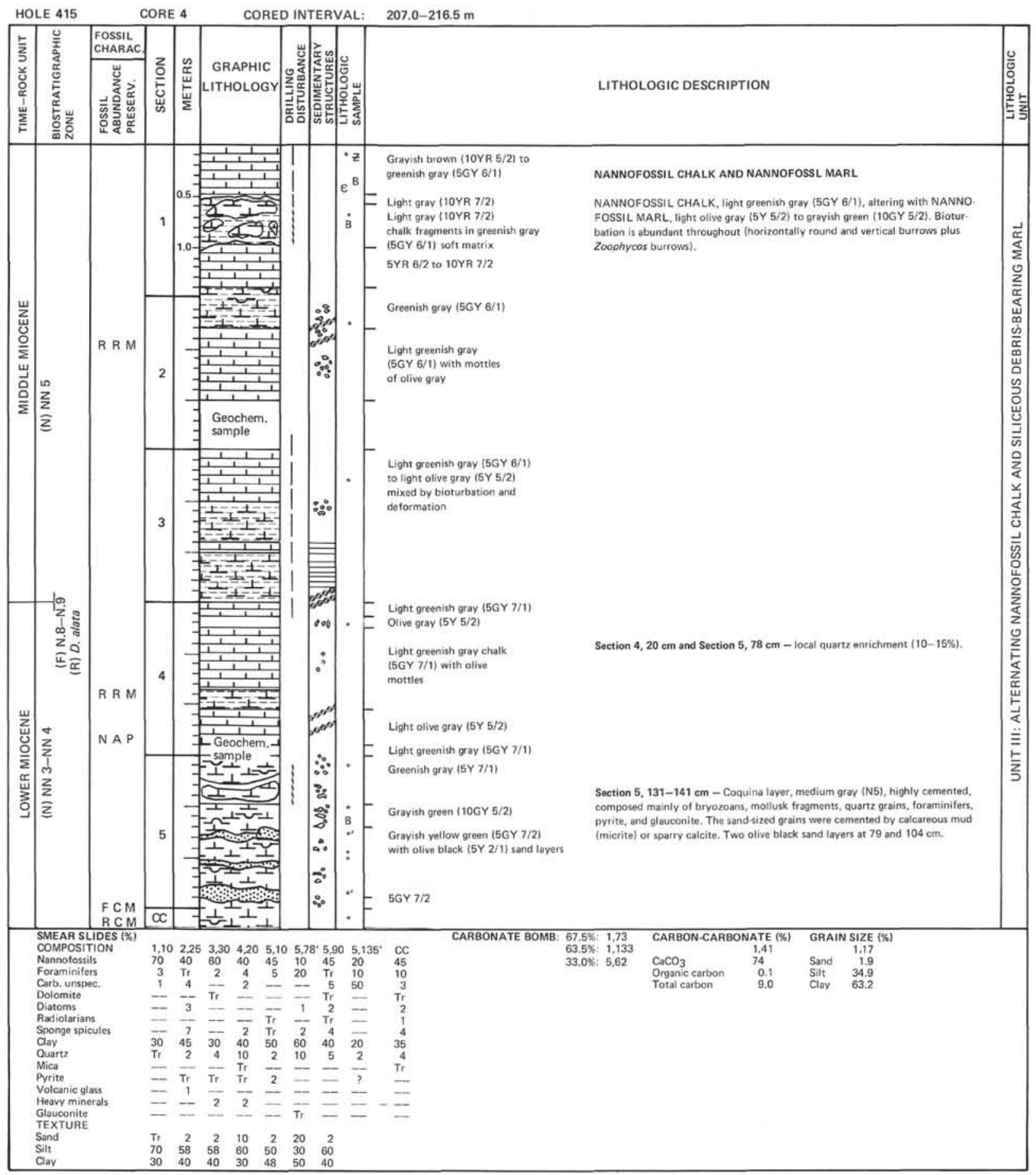


Site 415

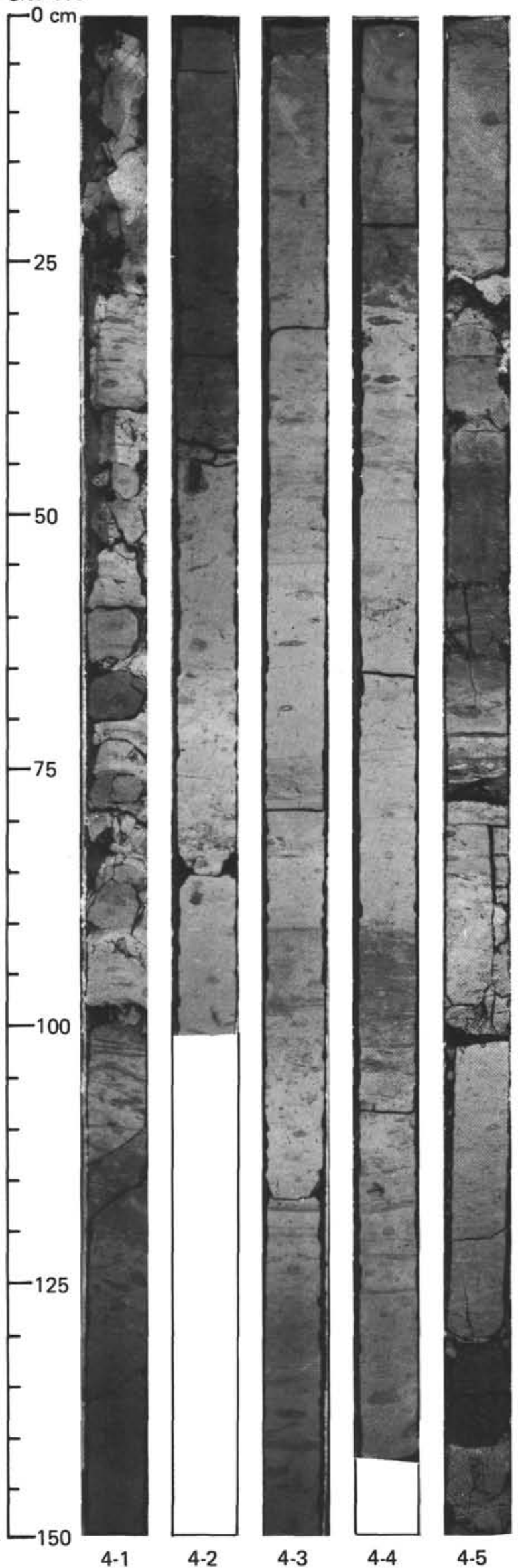




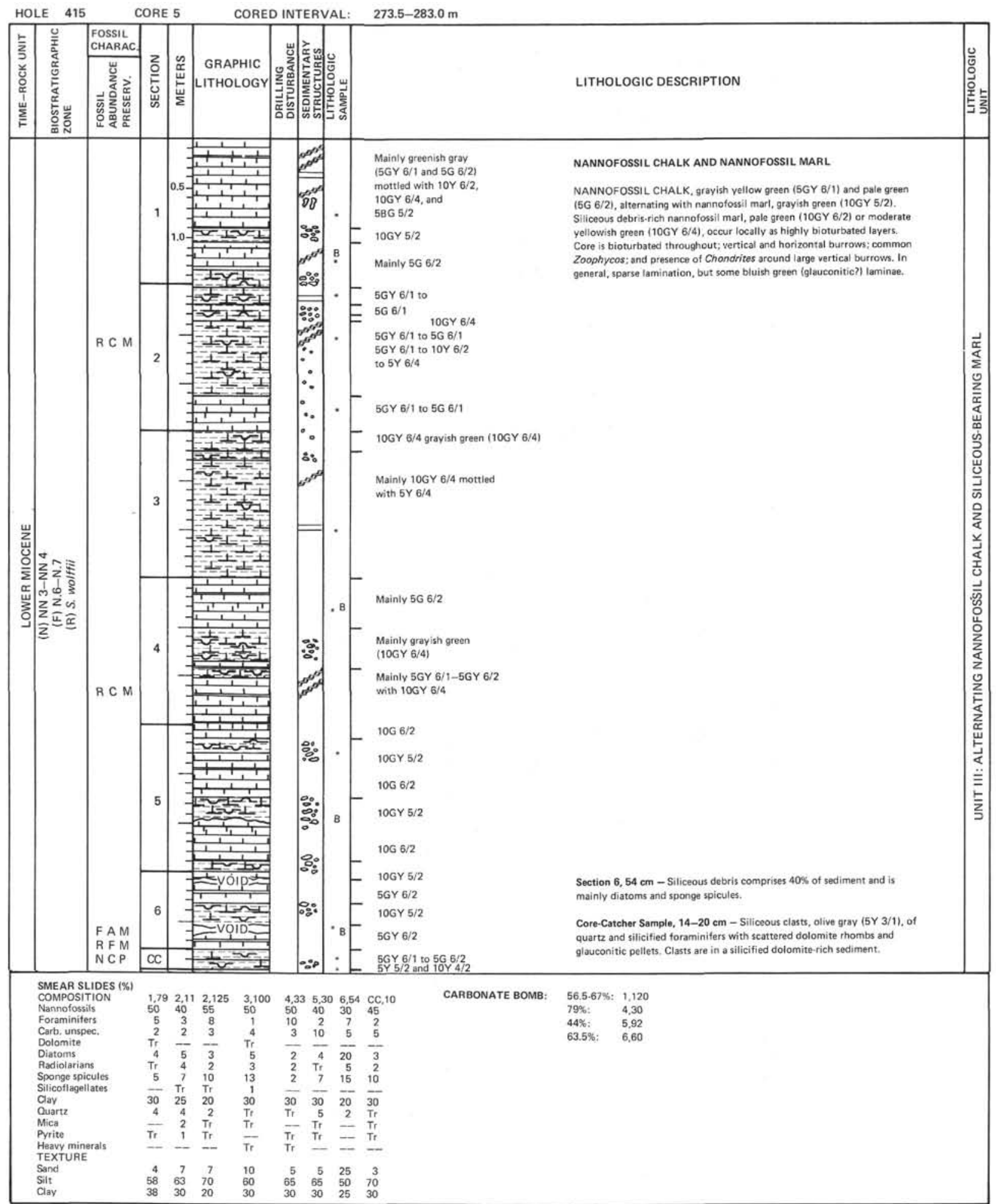




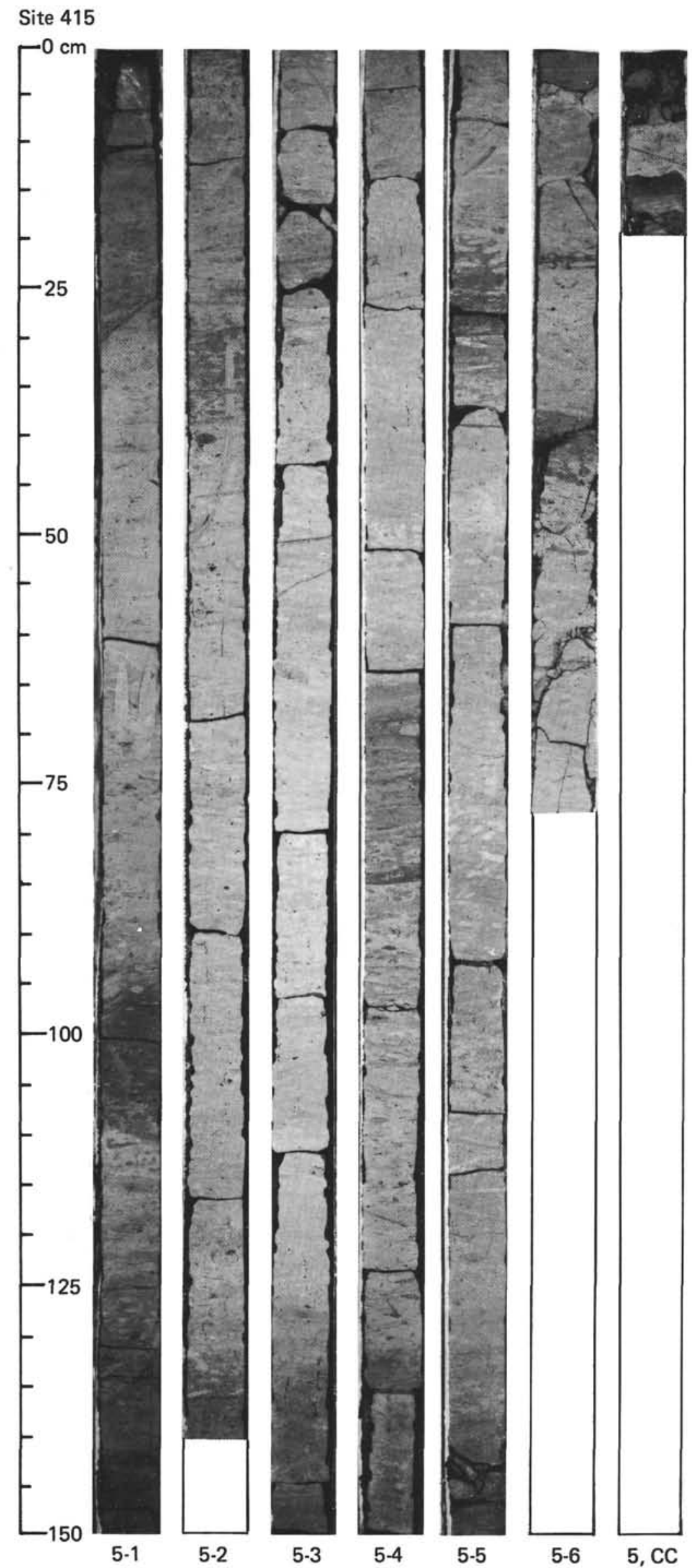




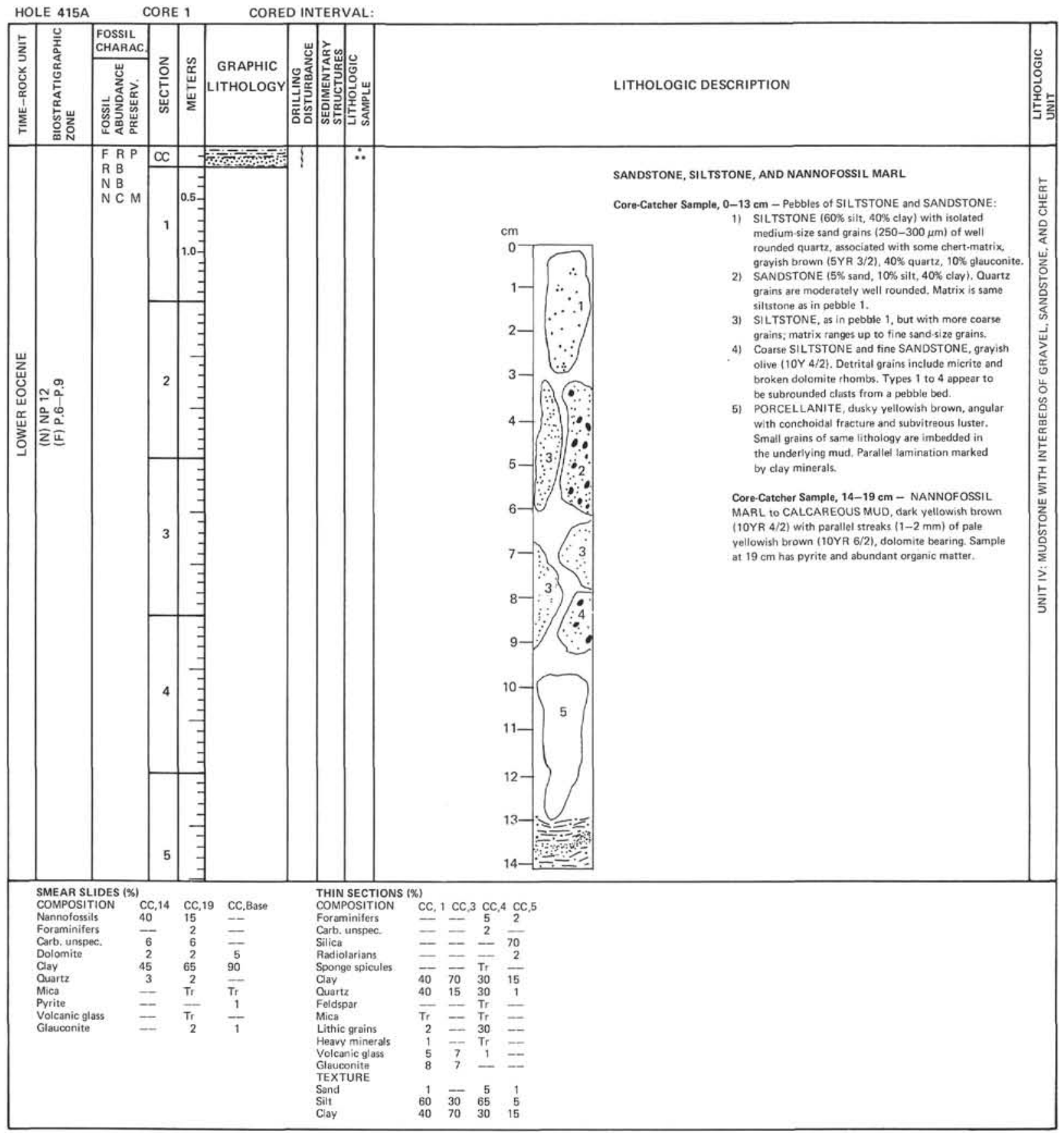



SITE 415

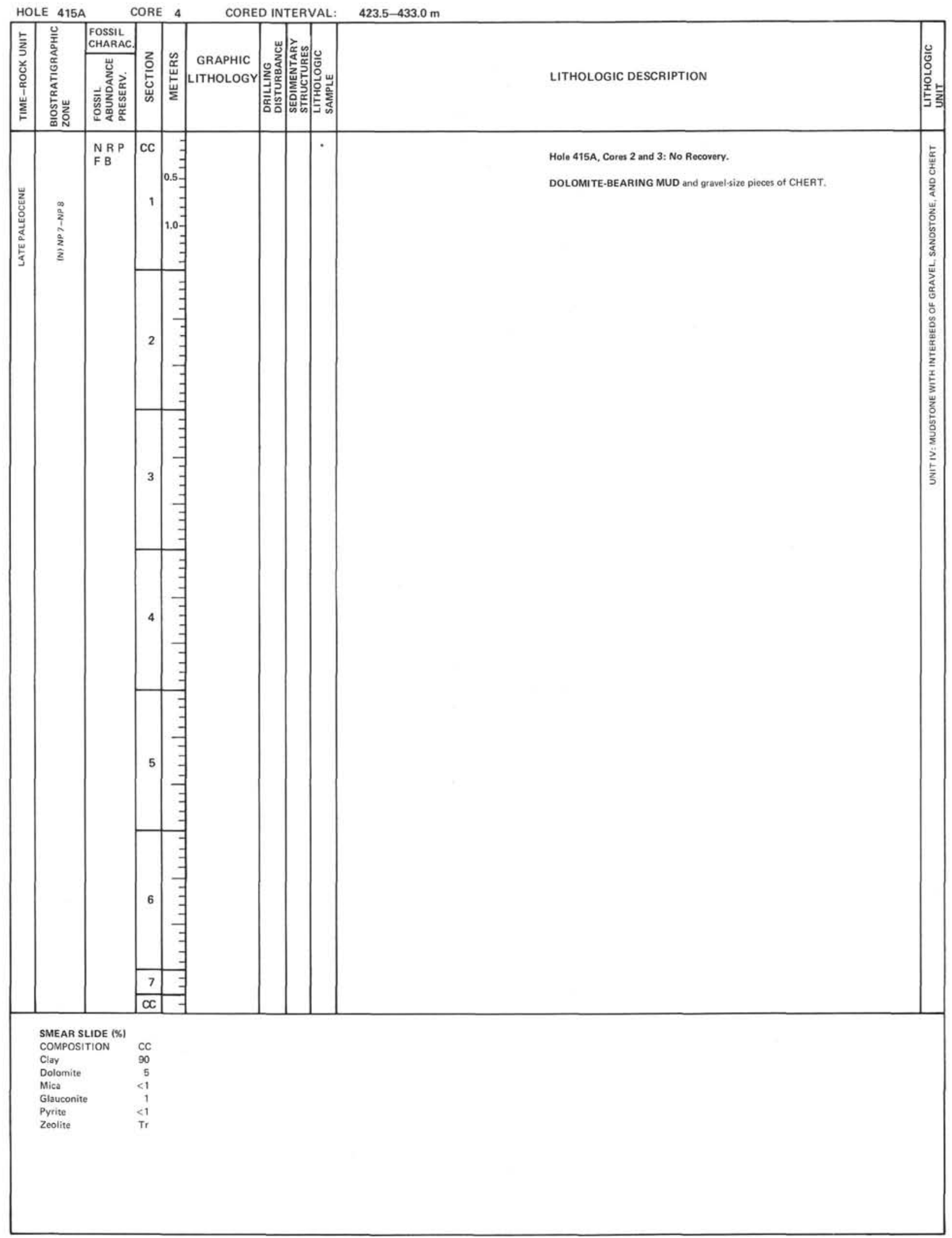


Hole 415A

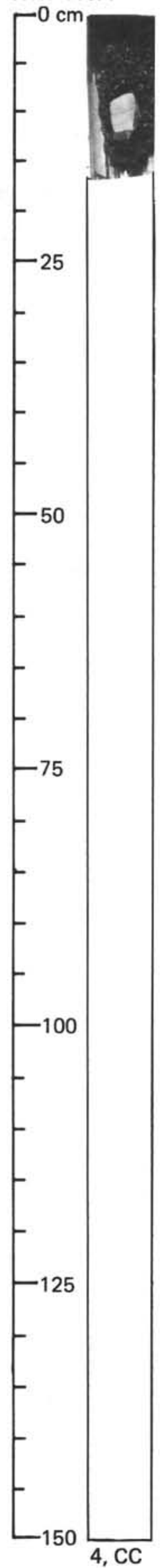


SITE 415

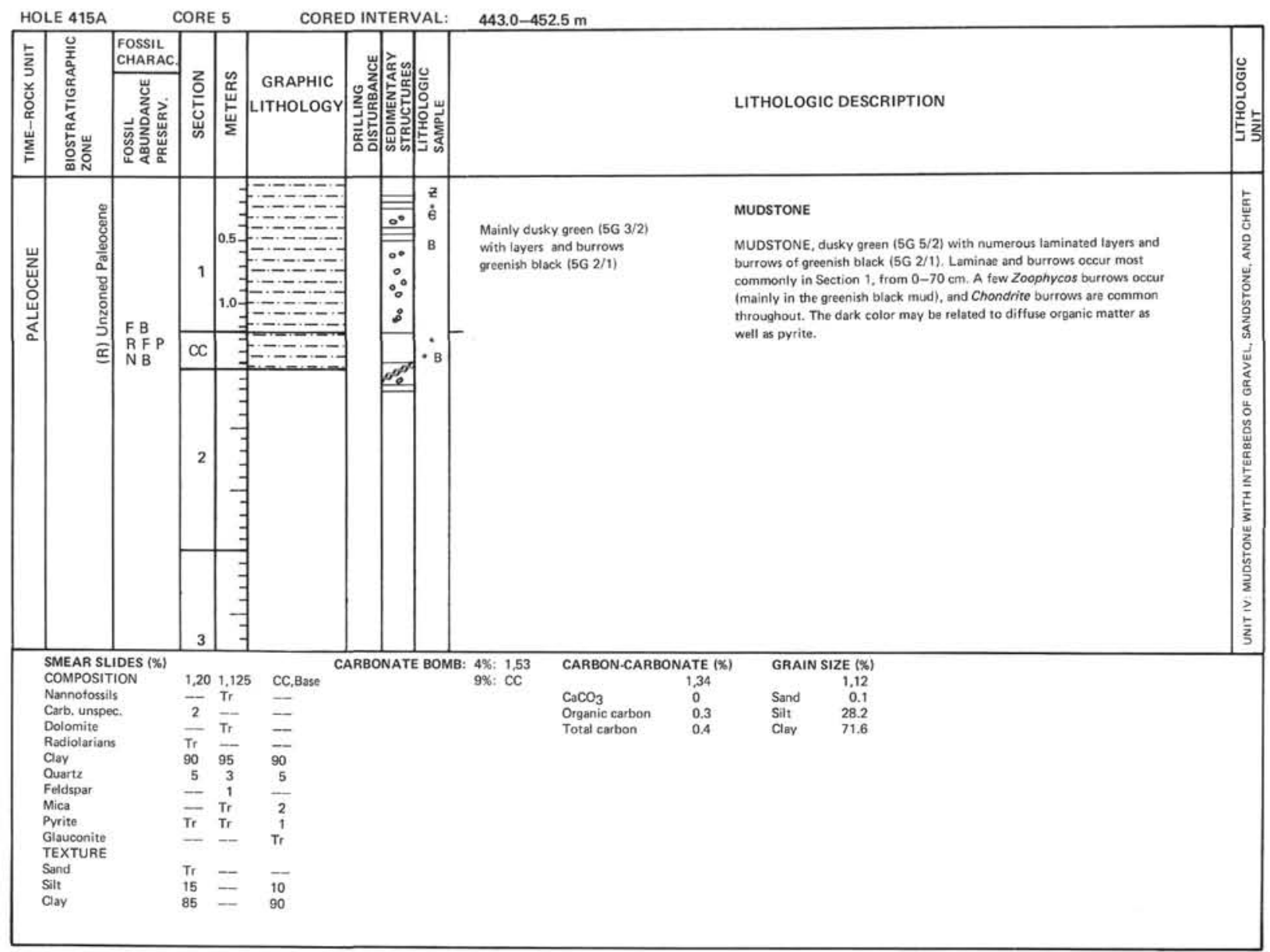


Hole 415A

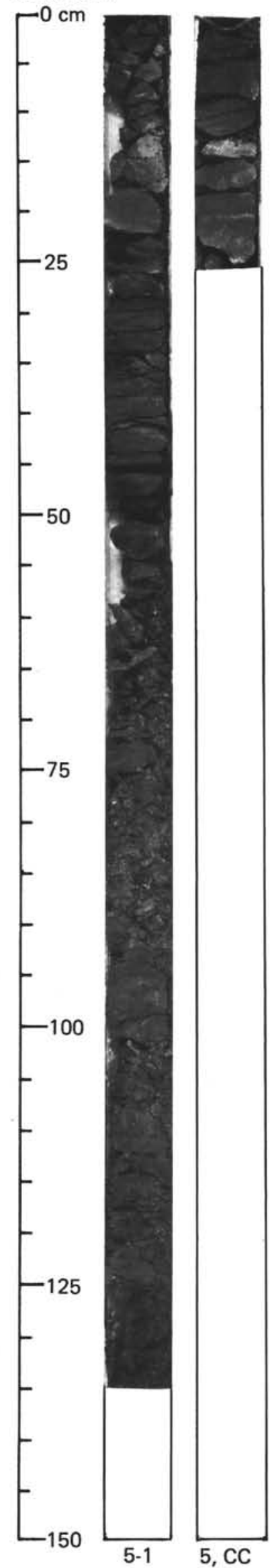




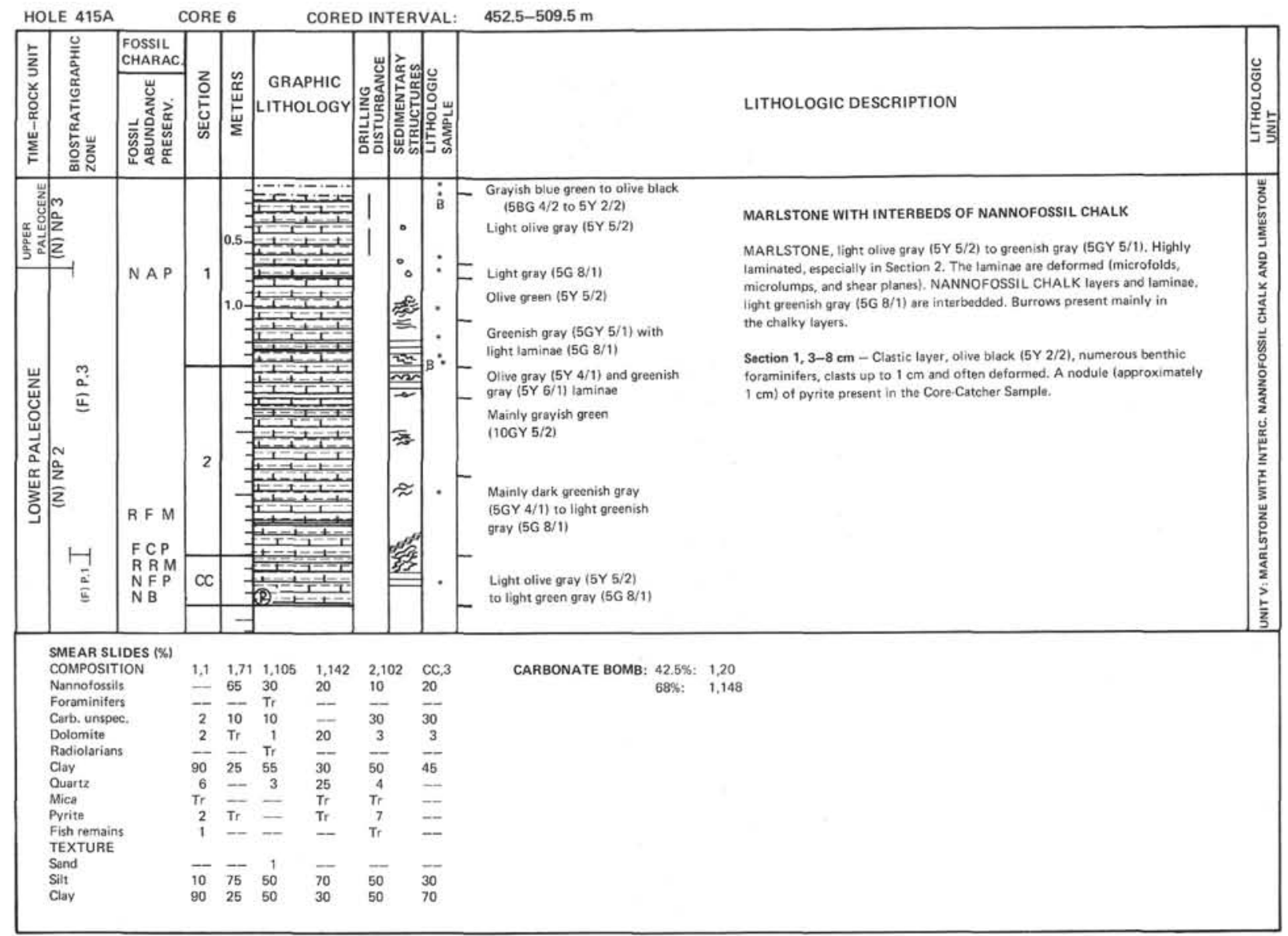

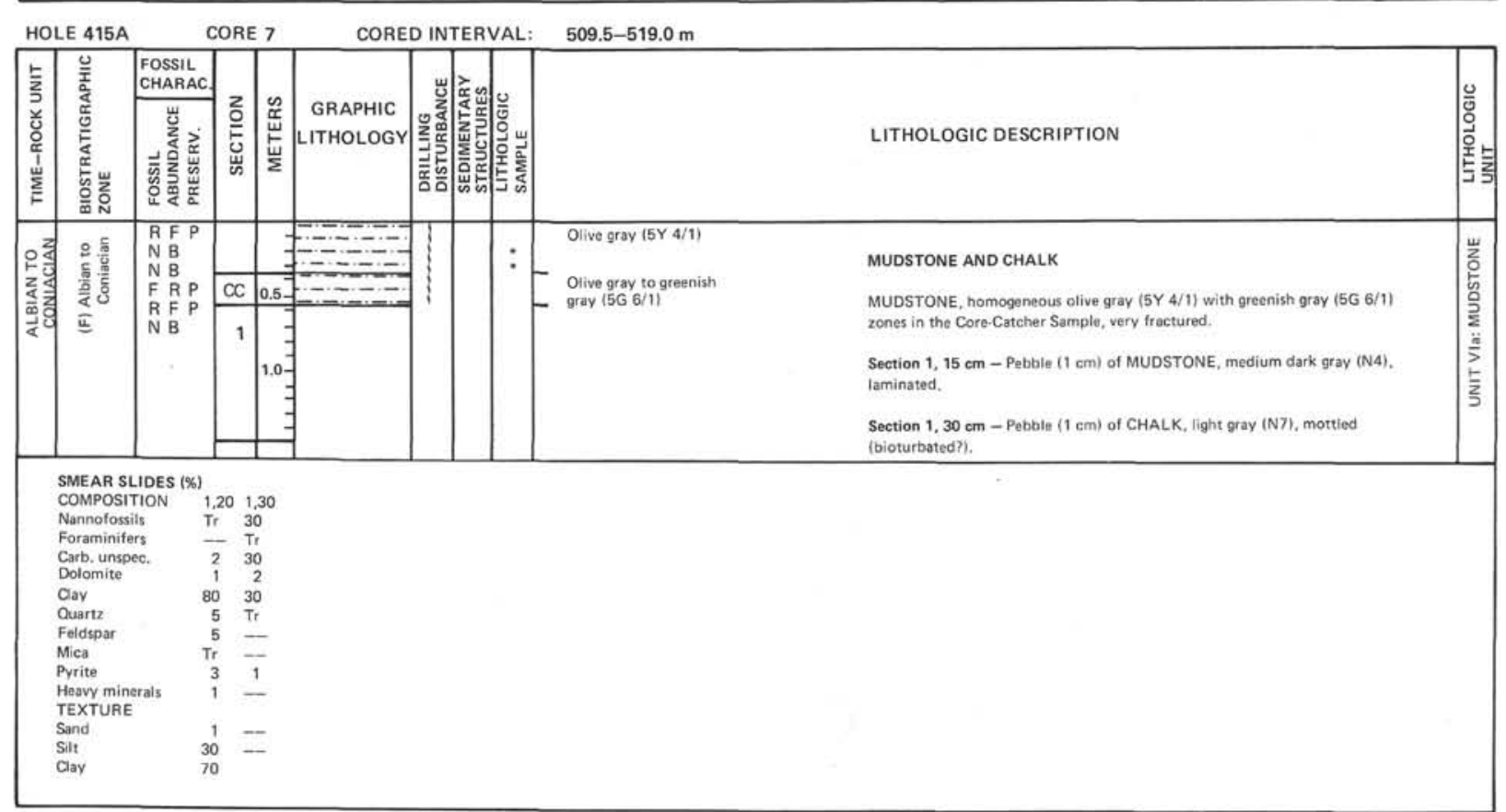


Hole 415A

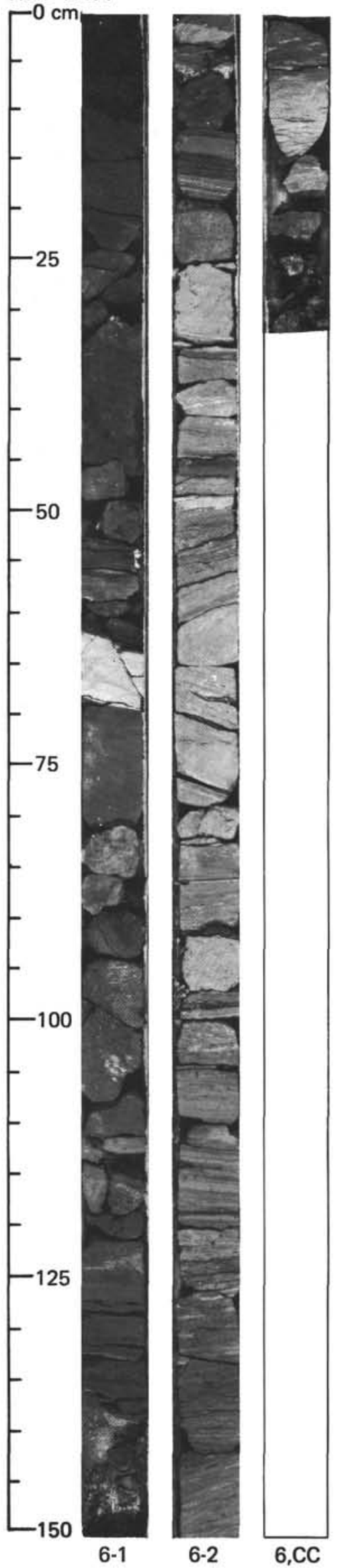

Hole 415A

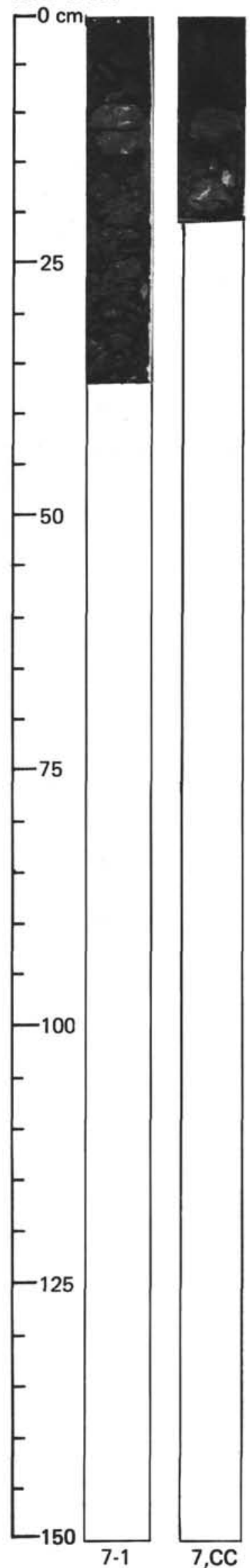




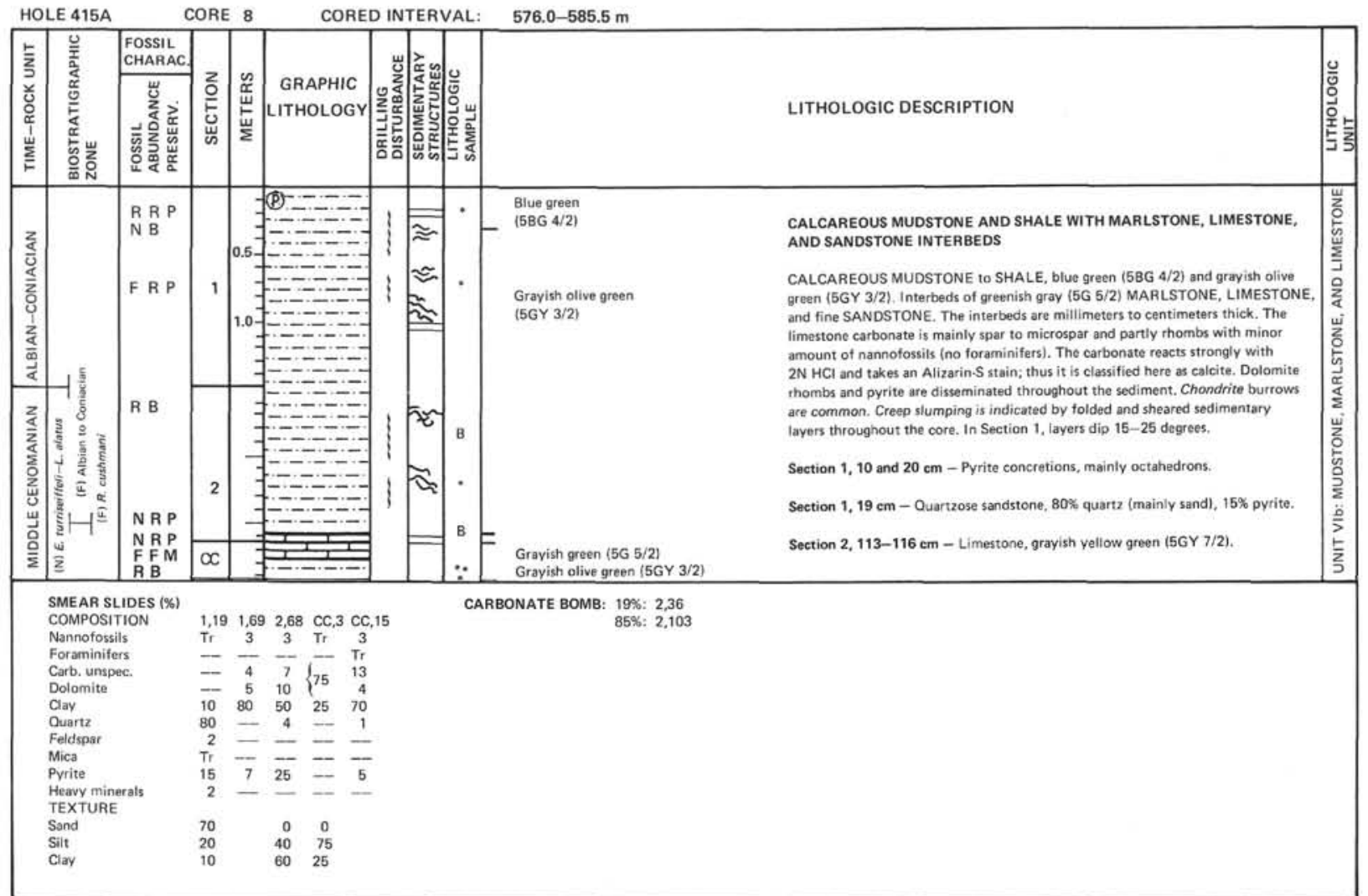


Hole 415A

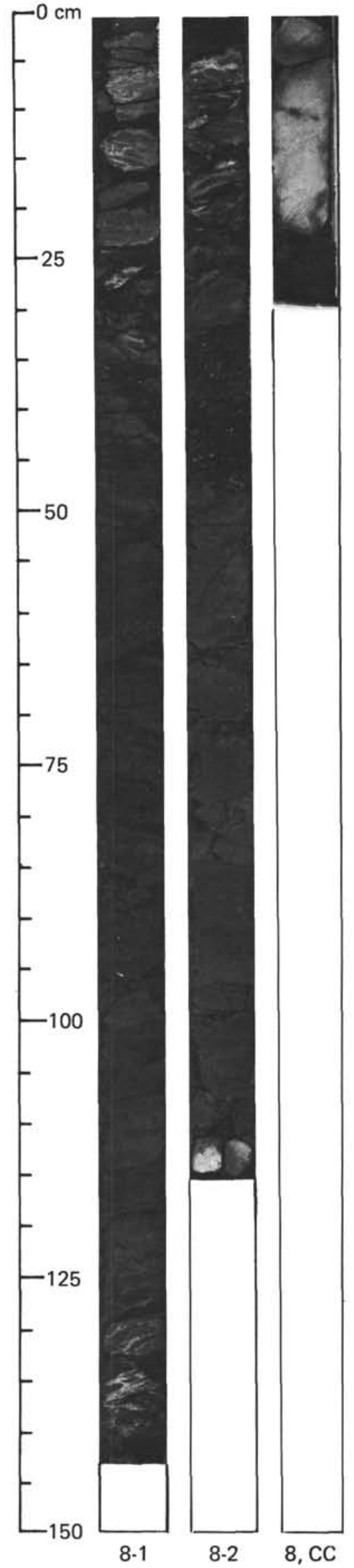




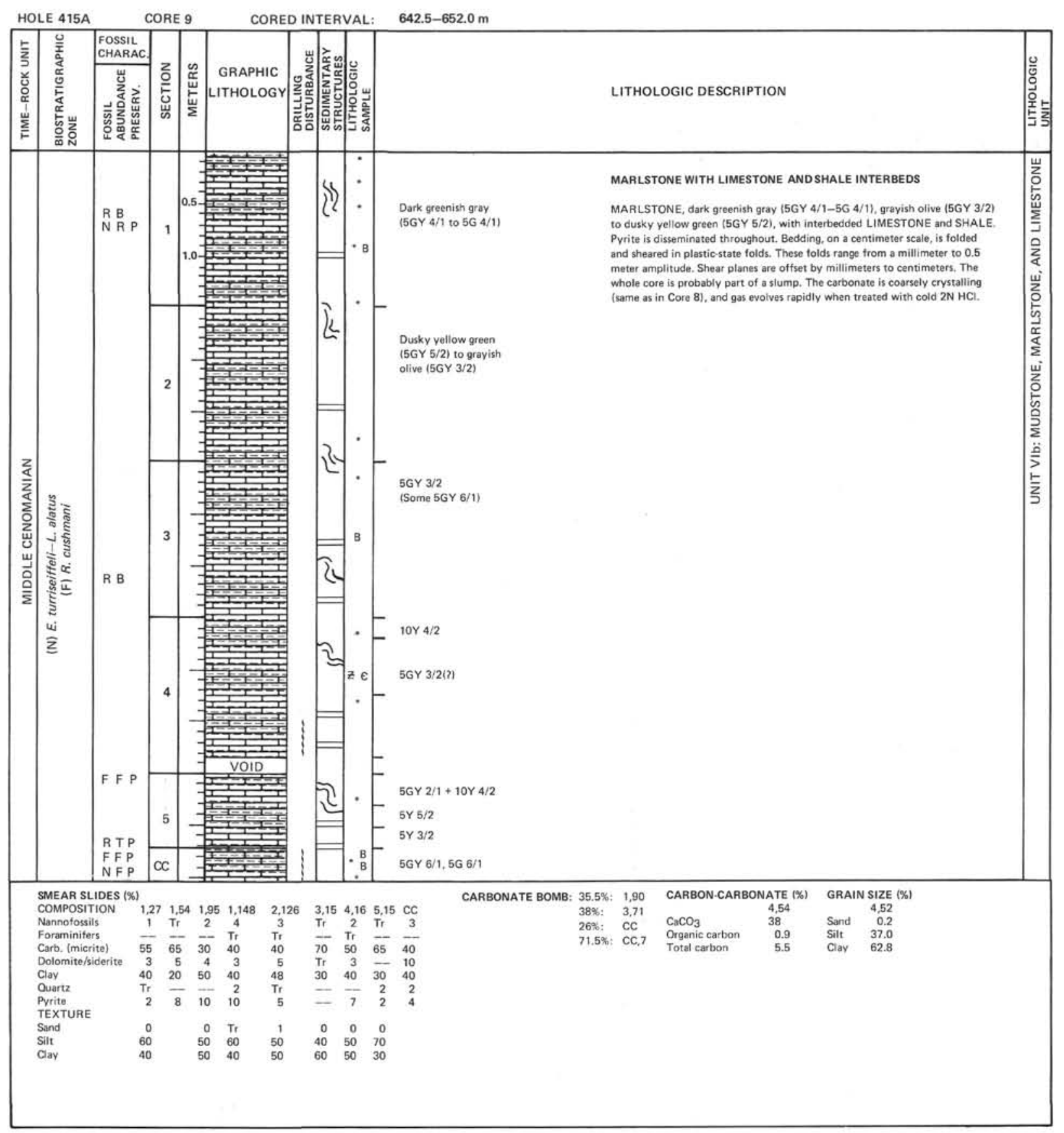




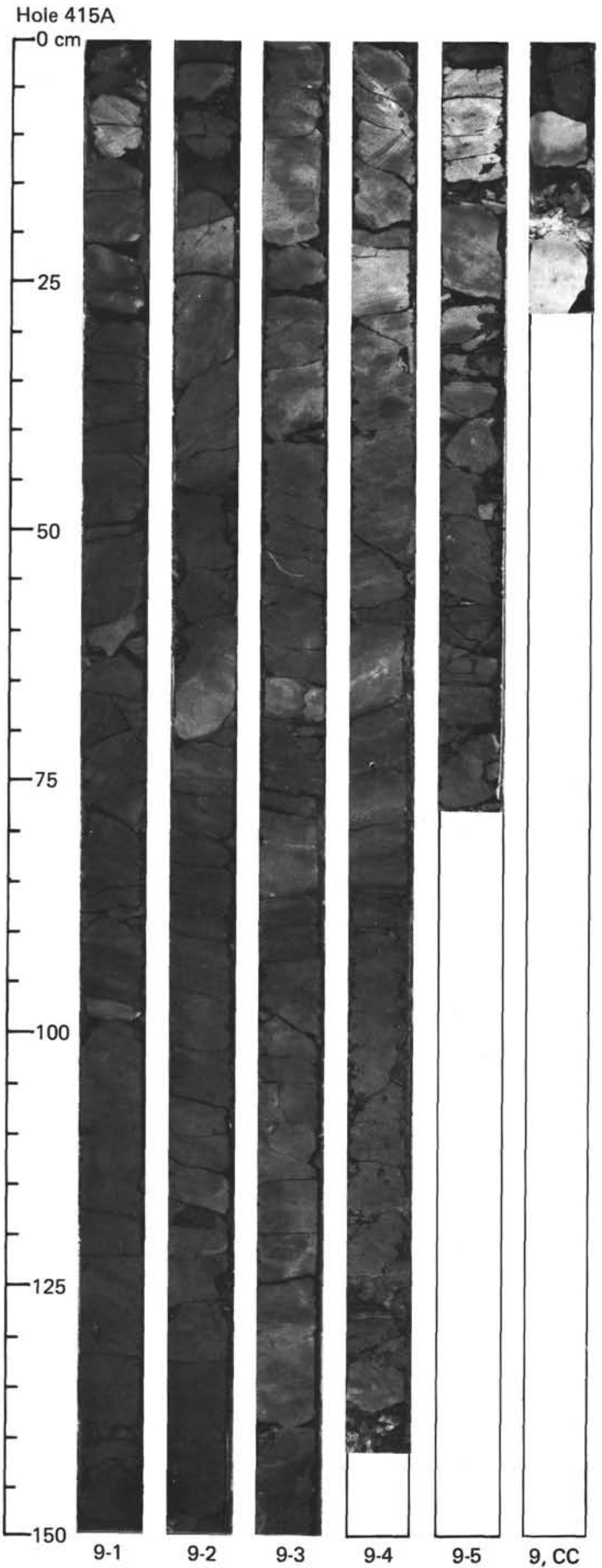




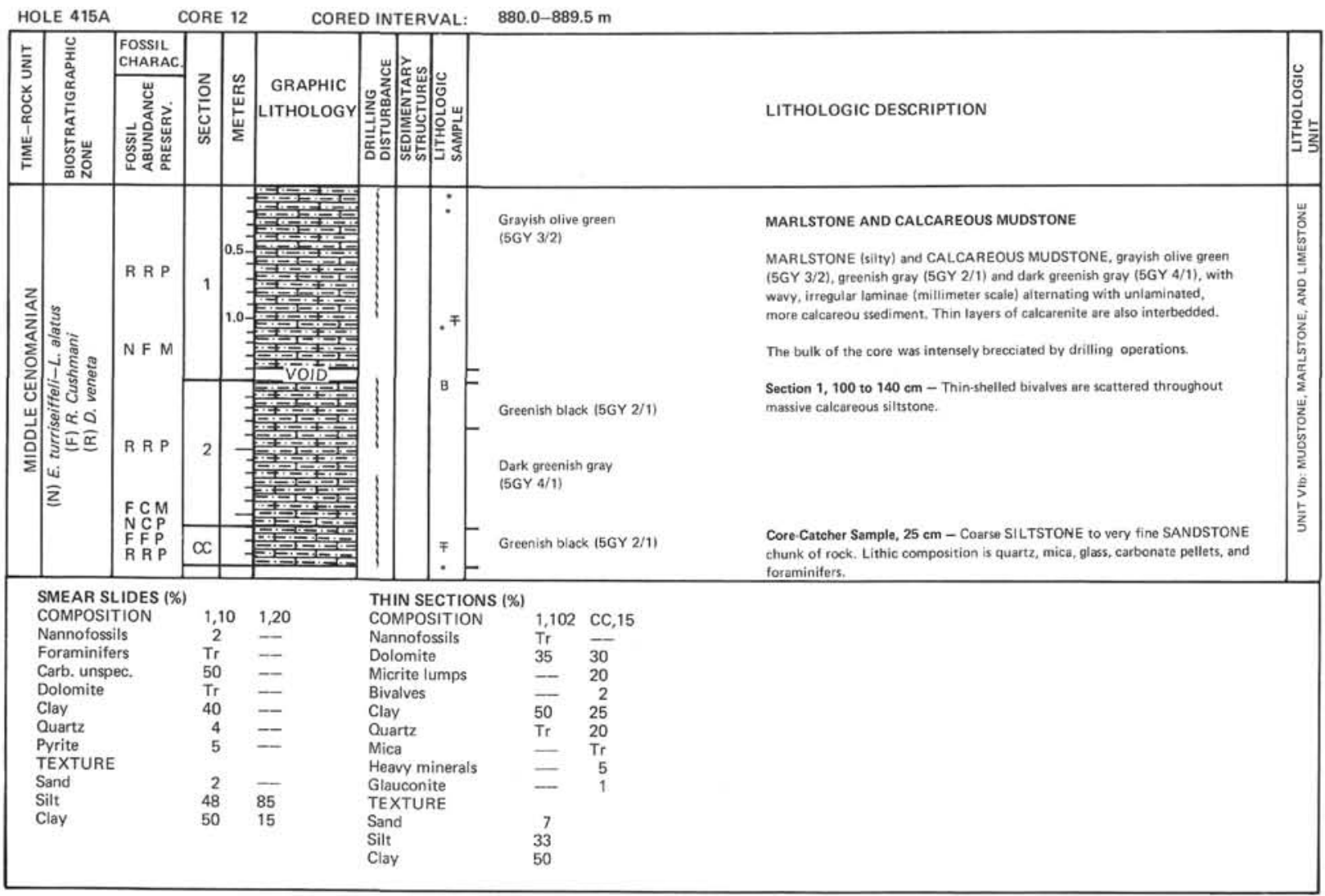

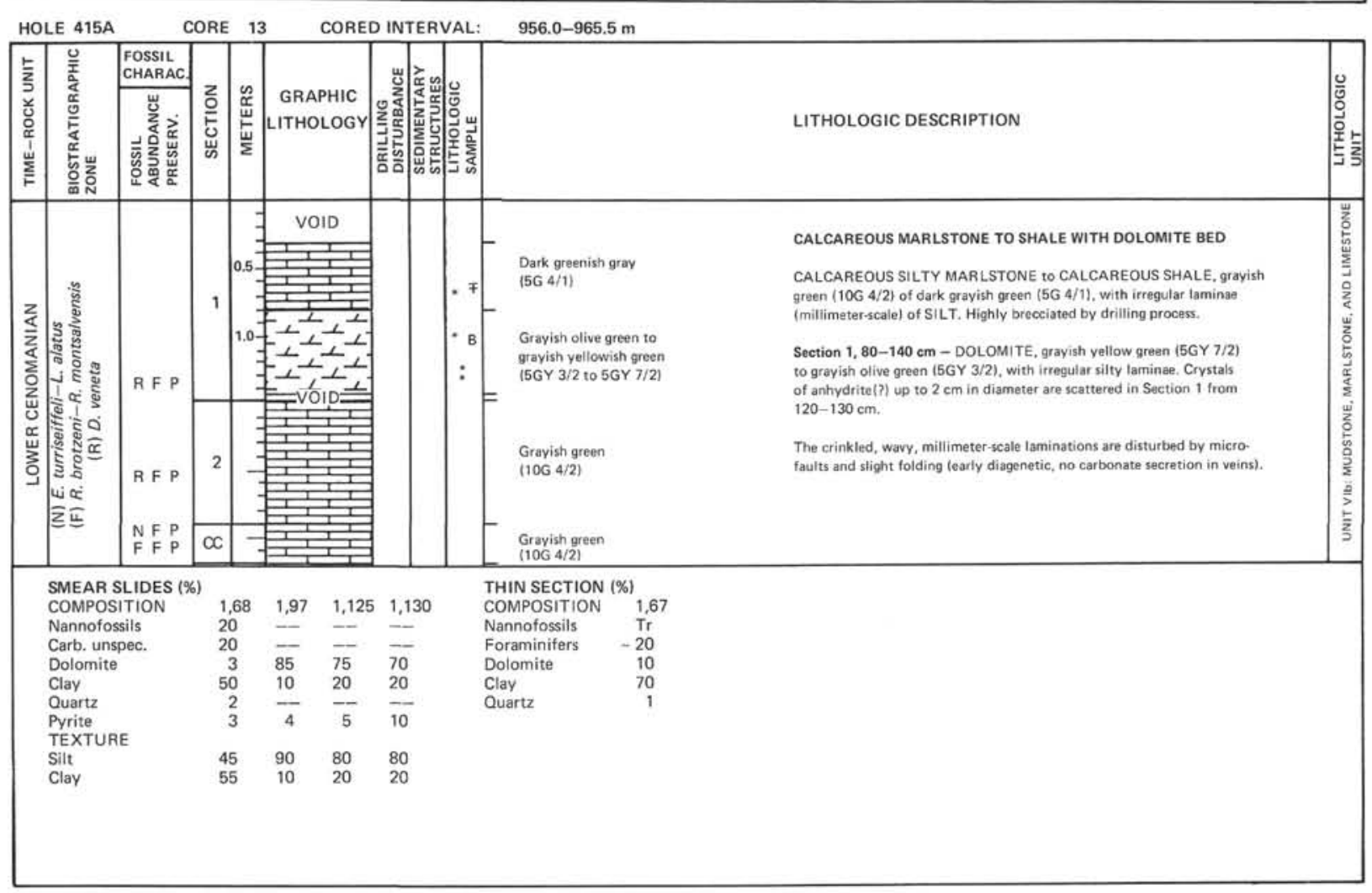




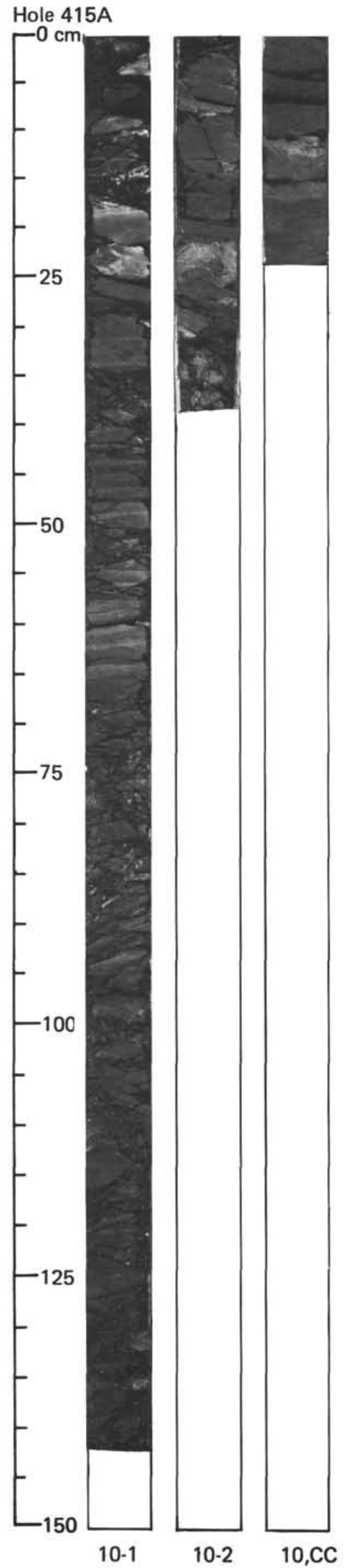

Hóle 415A

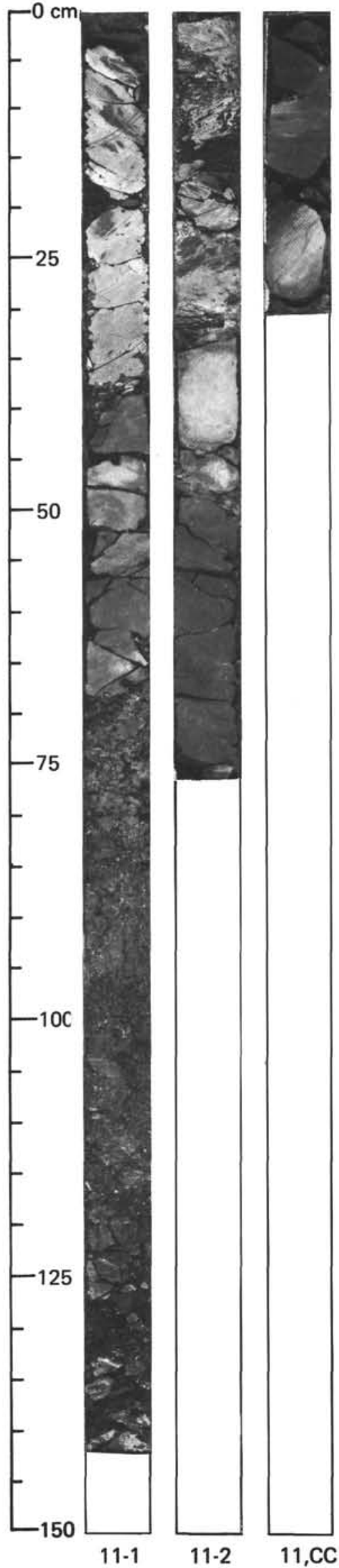




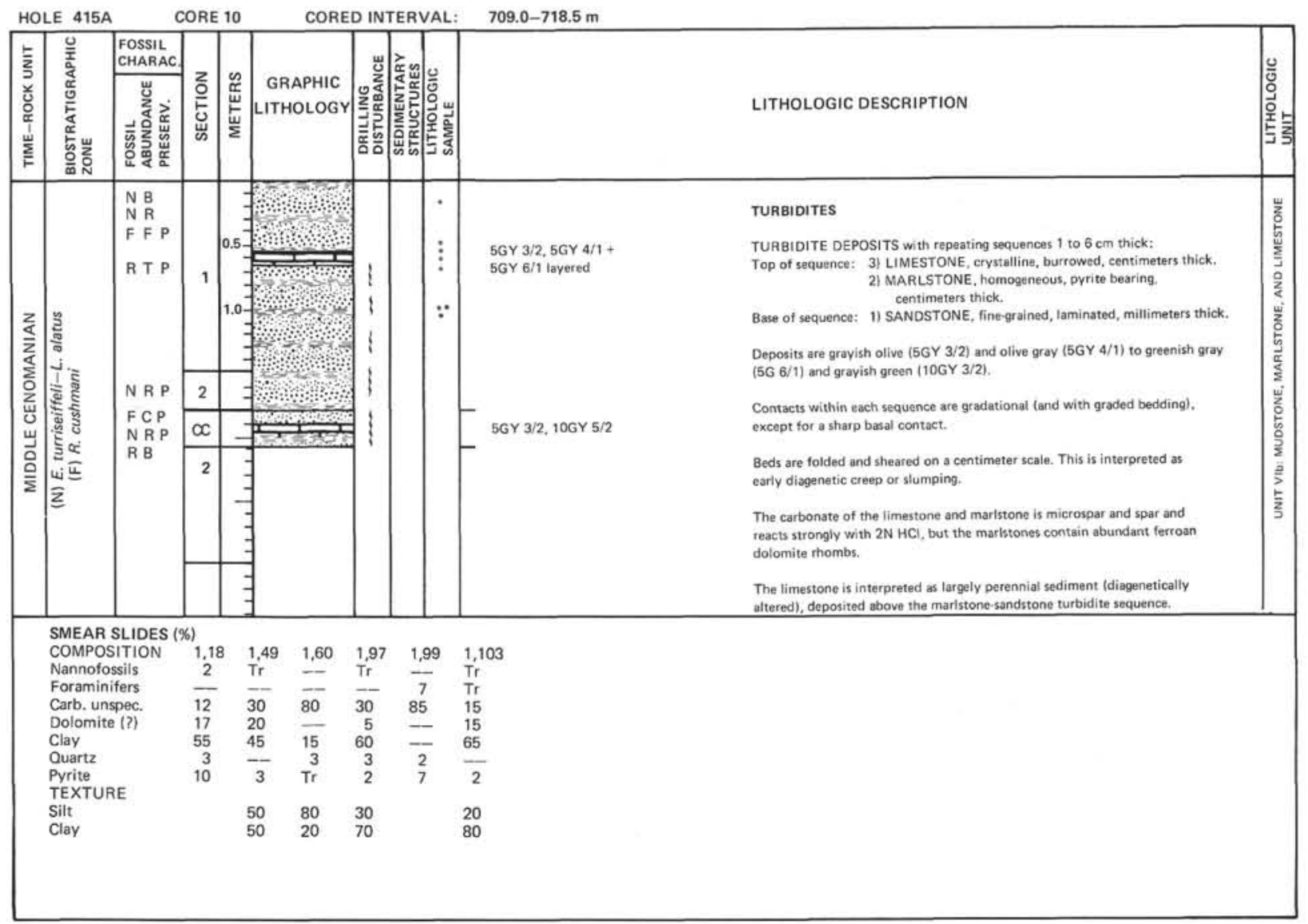

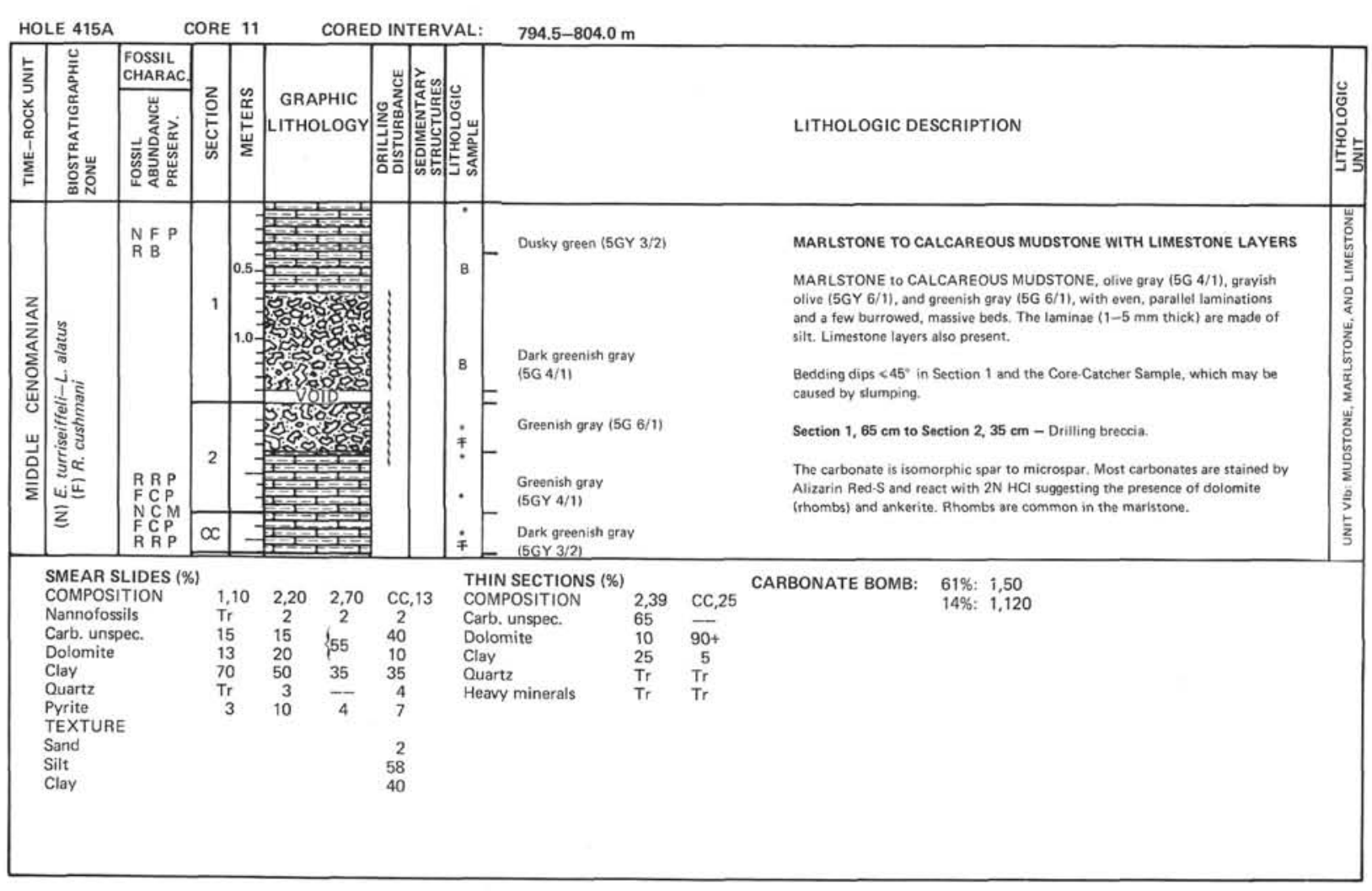


Hole 415A

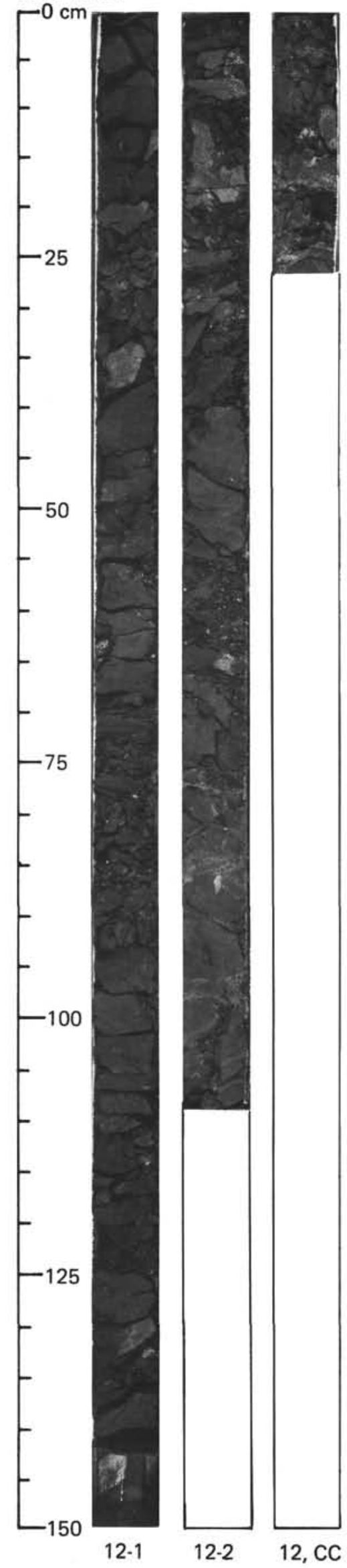

Hole 415A

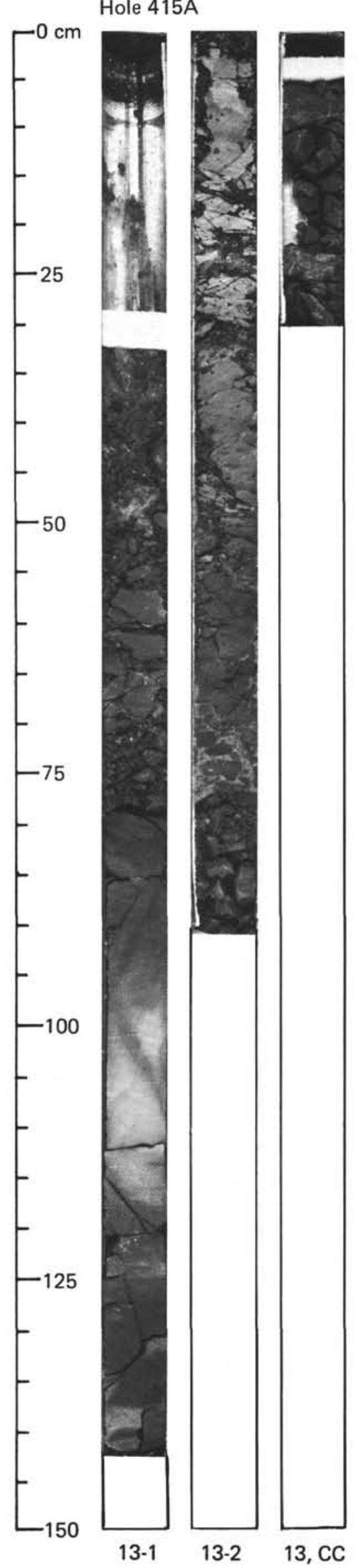




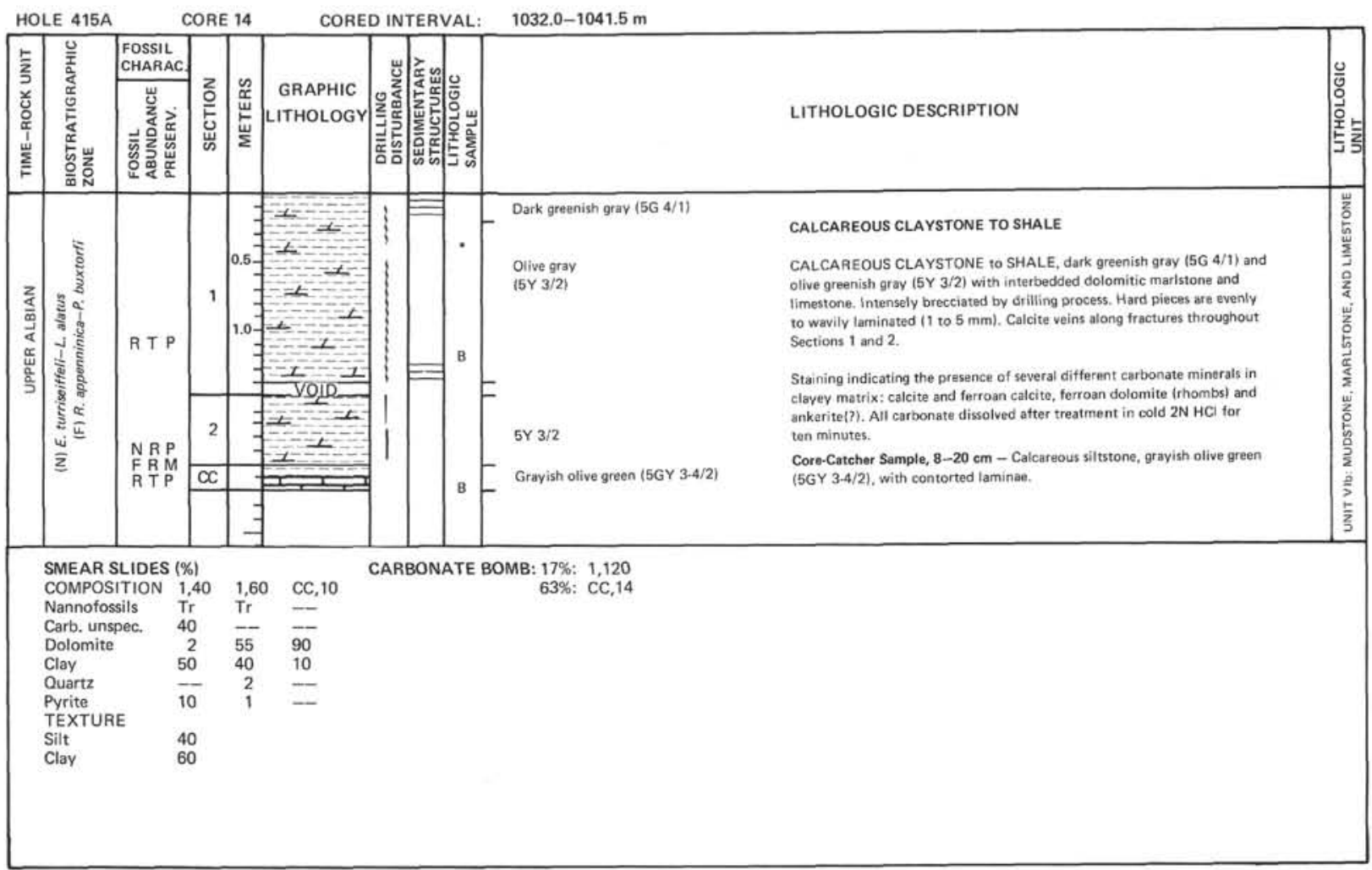

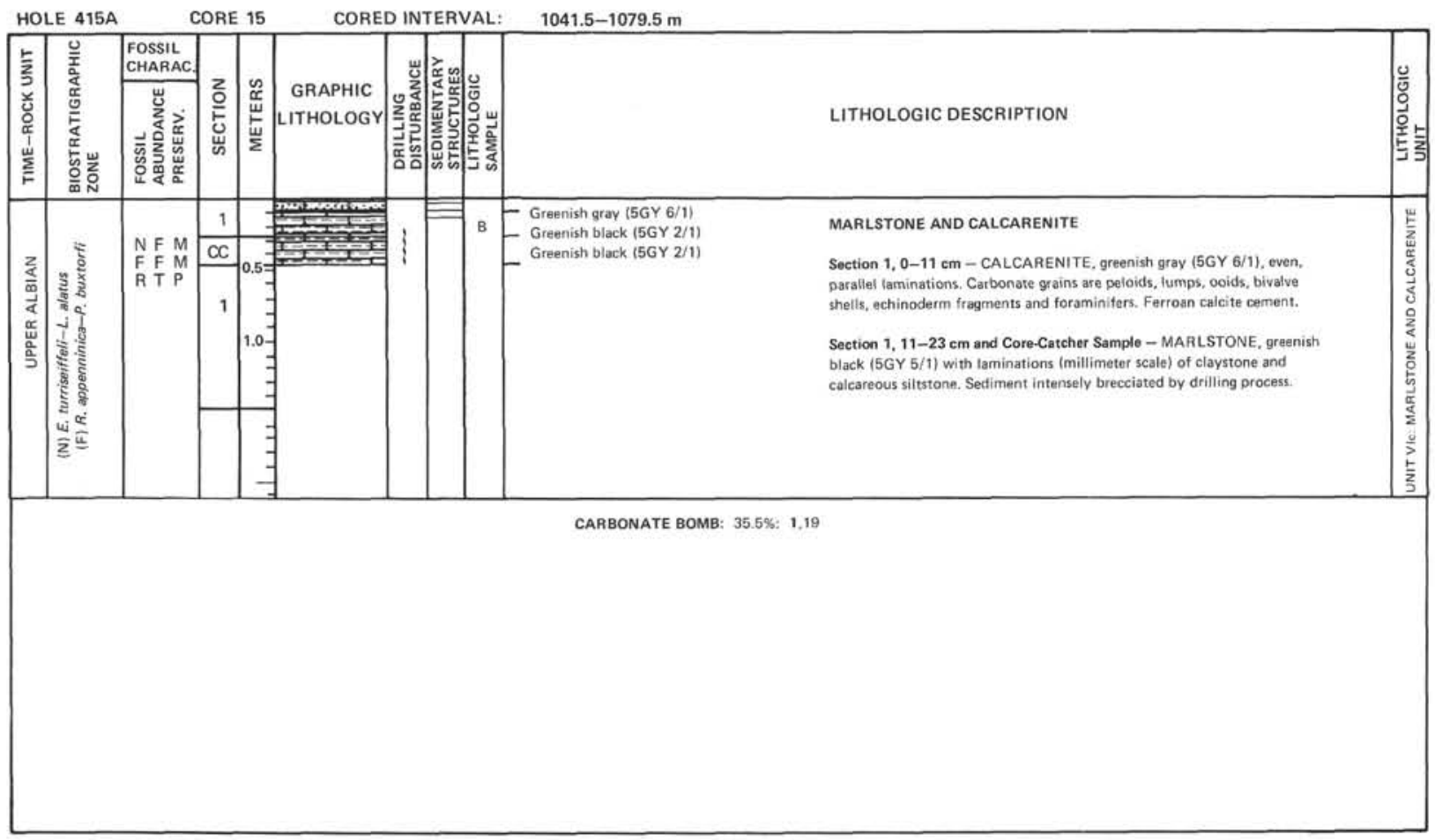


Hole 415A

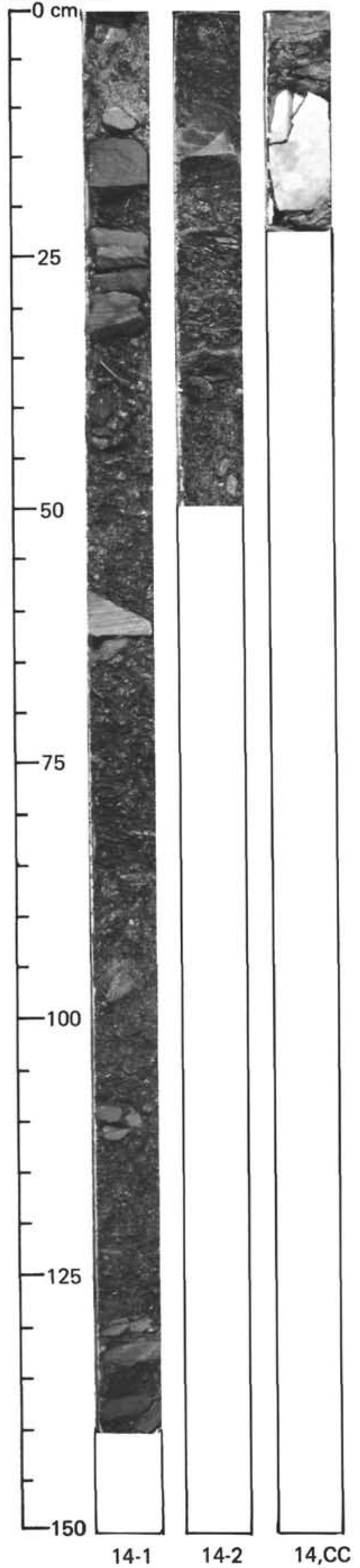

Hole 415A

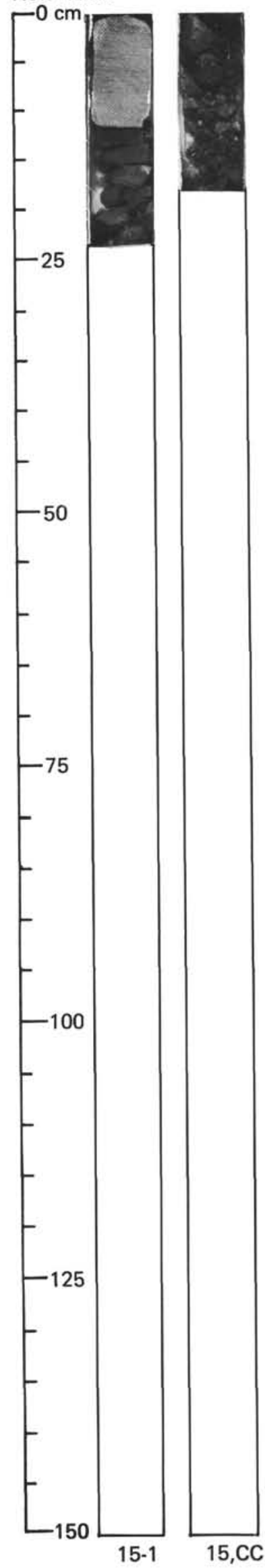




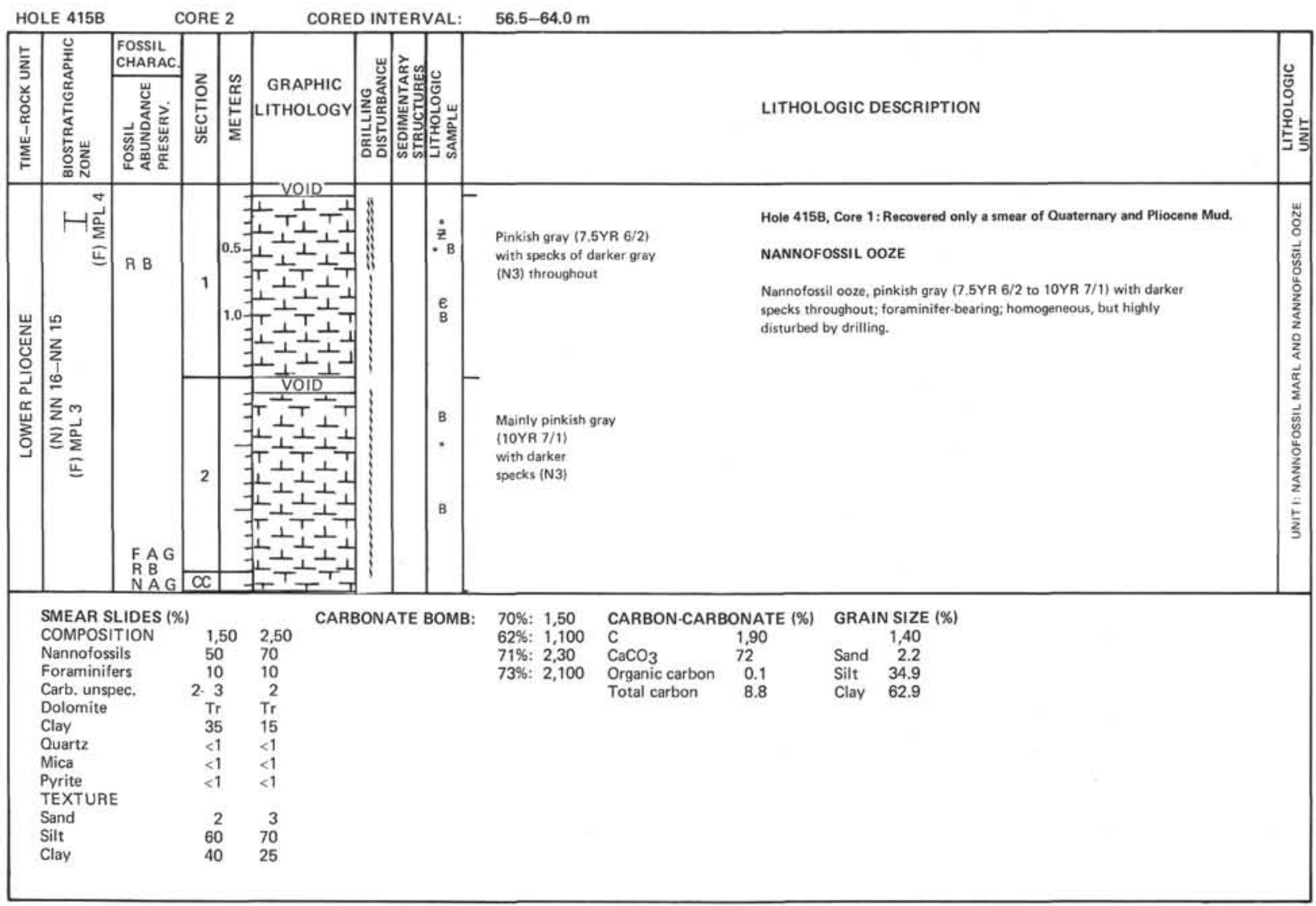


Hole 415B

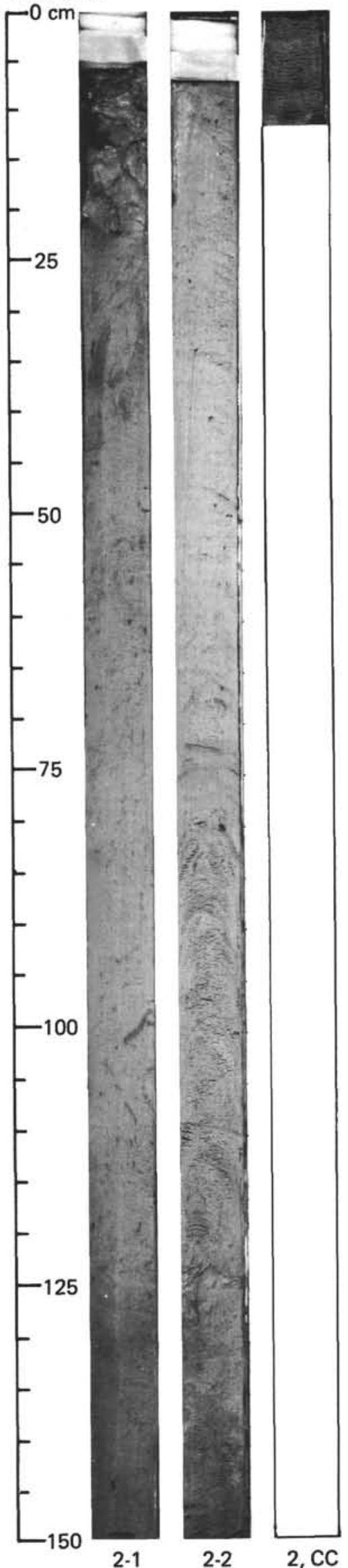

